Florida International University FIU Digital Commons

$12-2-1992$

\title{
One hundred years of servitude : the Colombian labor movement 1848-1948
}

Curtis Curry

Florida International University

DOI: $10.25148 /$ etd.FI14061575

Follow this and additional works at: https://digitalcommons.fiu.edu/etd

Part of the Latin American Studies Commons

\section{Recommended Citation}

Curry, Curtis, "One hundred years of servitude : the Colombian labor movement 1848-1948" (1992). FIU Electronic Theses and Dissertations. 2699.

https://digitalcommons.fiu.edu/etd/2699

This work is brought to you for free and open access by the University Graduate School at FIU Digital Commons. It has been accepted for inclusion in FIU Electronic Theses and Dissertations by an authorized administrator of FIU Digital Commons. For more information, please contact dcc@fiu.edu. 


\title{
ABSTRACT OF THE THESIS
}

One Hundred Years of Servitude:

The Colombian Labor Movement 1848-1948

by

\author{
Curtis D. Curry \\ Florida International University, 1992 \\ Miami, Florida \\ Professor Guillermo Grenier, Major Professor
}

The current study seeks not only to place into focus the general patterns of social and economic organization prevalent in Colombia in the late nineteenth century and the early twentieth (such political and economic organization has been ably illustrated by several authors), but also strives to elucidate the systems of thought or 'ideologies' to which such socio-economic and political structures gave rise. It is concerned with the thought-systems that influenced the development of the Colombian labor movement, those of actors external to organized labor and indigenous systems of thought of labor activists themselves.

The hypothesis is that class and party-based interests channelled the early development of organized labor toward a path that would further, or failing that, not conflict with dominant élite interests. Artisans, proudly independent, exerted inordinate influence over the movement, hindering the development of working class consciousness. As the result of dominance by élites external to the labor movement itself, workers were never able to forge an independent voice that would allow them to define their own interests in society. 


\title{
FLORIDA INTERNATIONAL UNIVERSITY
}

\author{
Miami, Florida
}

One Hundred Years of Servitude:

The Colombian Labor Movement 1848-1948

\author{
A thesis submitted in partial satisfaction \\ of the requirements for the degree of Master of Arts \\ in International Studies
}

by

Curtis D. Curry

1992 
To Professors Guillermo Grenier, Douglas Kinkaid and Alex Stepick:

This thesis, having been approved in respect to form and mechanical execution, is referred to you for judgement upon its substantial merit.

Dean Arthur Herriott

College of Arts and Sciences

The thesis of Curtis D. Curry is approved.

Douglas Kincaid

Alex Stepick

Guillermo Grenier, Major Professor

Date of examination: December 2, 1992

Dean Richard L. Campbell

Division of Graduate Studies

Florida International University, 1992 
LIST OF TABLES vi

Chapter

1. INTRODUCTION 1

REVIEW OF THE RELEVANT LITERATURE ON COLOMBIAN LABOR 3

METHODOLOGY: OVERVIEW OF THE APPROACH 13

IDEAS AND SOCIAL REALITY 16

2. COLONIAL COLOMBIA 31

INTRODUCTION 31

The Cross and the Crown $\quad 32$

The Colonial Economy $\quad 36$

SOCIAL THOUGHT AND IDEOLOGY IN THE COLONY AND THE
EARLY REPUBLIC

Economic Factors $\quad 42$

Ideological Currents $\quad 45$

Independence $\quad 48$

$\begin{array}{ll}\text { CONCLUSION } & 49\end{array}$

3. NINETEENTH CENTURY COLOMBIA

THE EARLY REPUBLIC $\quad 55$

CONFLICT AND IDEOLOGY: THE BIRTH OF THE TWO-PARTY SYSTEM 59

Conservatives and Liberals $\quad 59$

Regionalism and the Geography of Colombia 66

$\begin{array}{ll}\text { Federalism } & 70\end{array}$

Artisans and the Liberal Party: Las Sociedades Democraticas $\quad 73$

FEDERALISM AND LIBERAL REFORMS $\quad 78$

Emancipation of Resguardo Lands and the Abolition of Slavery 80

The Roman Catholic Church and Liberal Reforms 82

General Economic Trends Affecting Artisan Production 84

Social Conditions: The Distinct Worlds of Artisans and Upper Class $\quad 86$

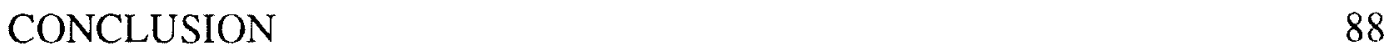

4. UTOPIAN SOCIALISM, IDEOLOGY AND CLASS CONFLICT IN THE 91 NINETEENTH CENTURY

THE INFLUENCE OF UTOPIAN SOCIALISM 91 
ARTISAN CLASS CONSCIOUSNESS AND CONFLICT

The Liberal Party Fractures: Gólgotas and Draconianos

The Artisan Republic of 1854

ARTISAN PRODUCTION IN THE SECOND HALF OF THE NINETEENTH CENTURY

Rafael Nuñez and the Artisans $\quad 108$

$\begin{array}{ll}\text { The Mutualist Societies } & 112\end{array}$

CONCLUSION

5. VICTORY IN DEFEAT: CONSOLIDATION OF THE LIBERAL EXPORT ECONOMY

MYTH OF THE DEMOCRATIC FRONTIER: LABOR AND LAND IN

THE COUNTRYSIDE

THE RISE OF THE EXPORT ECONOMY: TOBACCO AND COFFEE

RAFAEL NUÑEZ AND THE RISE OF SOCIAL CONSERVATIVISM

WAR OF A THOUSAND DAYS AND THE PANAMA CRISIS

CONCLUSION: CONSOLIDATION OF THE LIBERAL EXPORT ECONOMY

6. EARLY INDUSTRIAL DEVELOPMENT AND THE EMERGENCE OF A PROLETARIAT

INTRODUCTION

THE NASCENT LABOR MOVEMENT'S STRUGGLE TO ASSERT ITS AUTONOMY: 1910-1928

Artisans, Socialists, Anarchists, and Working Class Politics

$\begin{array}{ll}\text { Strikes and Repression } & 158\end{array}$

Dance of the Millions $\quad 166$

The Conservative Party Fractures $\quad 170$

CONCLUSION

7. LABOR AND THE LIBERAL REVOLUCIÓN EN MARCHA 177

LOS NUEVOS, SOCIALISM, AND A NEW IDEOLOGICAL ORIENTATION

THE RURAL PROTEST: SMALLHOLDER STRUGGLES TO ACQUIRE LAND TITLES 
LA REVOLUCÍON EN MARCHA

CREATION OF THE CONFEDERACION DE TRABAJADORES

DE COLOMBIA (CTC)

CONSERVATIVE REACTION

THE DECLINE OF LABOR'S POLITICAL INFLUENCE

206

GAITÁN AND THE LABOR MOVEMENT

209

CONCLUSION

212

8. CONCLUSION AND IMPLICATIONS FOR FUTURE RESEARCH

CONCLUSION

216

IMPLICATIONS FOR FUTURE RESEARCH

236

BIBLIOGRAPHY 


\section{LIST OF TABLES}

Table

$\underline{\text { Page }}$

3:1 Active Population in 1870

5:1 Coffee and Tobacco Exports in Thousands of Pesos

6:1 Average Annual Rates of Increase of Industrial Production, 1925-1953

6:2 Average Annual Percentage Growth in Value of Manufacturing Production: 1929-1949

6:3 Manufacturing Population of Departmental Capitals, 1905-1951

6:4 Freight Moved by the Railroad and Riverboats in Tons

7:1 Colombian Coffee Exports 1900-1925: Volume and Value

7:2 Cundinamarca's Coffee Farms in 1932 and 1940

8:1 Parcelas Abandoned During La Violencia, 1946-1966 


\section{CHAPTER 1}

\section{INTRODUCTION}

To use a simple analogy, what happens is that in our empirical investigation we become aware of the fact that we are observing the world from a moving staircase, from a dynamic platform, and, therefore, the image of the world changes with the changing frames of reference which various cultures create...In the world of visual objects, we acknowledge that completely. That you can only see various perspectives of a house and there is no view among them which is absolutely the house and in spite of that there is knowing because the various perspectives are not arbitrary. The one can be understood from the other. What we, without any difficulty, admit for the apperception of the visual world, we ought to admit for knowledge in general. ${ }^{1}$

Karl Mannheim, in a letter to Kurt H. Wolff, April 15, 1946

The ideas of the ruling class are in every epoch the ruling ideas: i.e., the class which is the ruling material force of society, is at the same time its ruling intellectual force. The class which has the means of material production at its disposal, has control at the same time over the means of mental production, so that thereby, generally speaking, the ideas of those who lack the means of mental production are subject to it. The ruling ideas are nothing more than the ideal expression of the dominant material relationships, the dominant material relationships grasped as ideas; hence of the relationships which make the one class the ruling one, therefore, the ideas of its dominance. The individuals composing the ruling class possess among other things consciousness, and therefore think...The division of labour, which we have already seen above as one of the chief forces of history up till now, manifests itself also in the ruling class as the division of mental and material labor, so that inside this class one part appears as the thinkers of the class (its active, conceptive ideologists, who make the perfecting of the illusion of the class about itself their chief source of livelihood), while the others' attitude to these ideas and illusions is more passive...

$$
\text { Karl Marx, The German Ideology } y^{2}
$$

Images of past and present reality are created as much by the social and cultural milieu in which the beholder observes his or her "reality" as they are by any physical, objective "reality" that may exist apart from the observer. Man must necessarily perceive reality through his own eyes, eyes that have been colored by the temporal and spatial constraints imposed on each individual by birth. Such perceptions are also influenced by the entire cultural infrastructure, complete with artifacts of a particular era, that bind an

${ }^{1}$ Letter written from Karl Mannheim to Kurt H. Wolff, (15 April 1946), quoted in Wolff's "The Sociology of Knowledge and Sociological Theory," The Sociology of Sociology (Larry T. Reynolds and Janice M. Reynolds eds., New York: David McKay Co., Inc., 1970), pp. 35-36.

${ }^{2}$ Quoted in Karl Marx's The German Ideology, in Robert C. Tucker, The Marx-Engels Reader (New York: W.W. Norton and Company, 1978), pp. 172-173. 
individual to a specific temporal "reality".

In our time, the general validity of this assumption may be illustrated by contrasting an international businessperson's view that he/she "knows the realities" of the world marketplace, and who disparages "ivory tower" assessments of contemporary economic or socio-political realities. At the other pole, we might look into the beliefs held by a few academicians, who wielding the scientific method, are certain that they alone possess a monopoly on comprehending ultimate "social reality." Who comprehends "reality", the businessman or the academician? Both perhaps?

Certainly this phenomenon of self-certainty, of comprehending the ultimate reality is not of recent vintage. Throughout recorded history, various factions and individuals have claimed ultimate, exclusive rights to both truth and comprehension of reality (recall the role Socrates ascribed to the Gold Souls in his ideal Republic, the philosopher-kings who alone possessed sufficient knowledge and comprehension of social reality to rule the body politic) often under various political and religious banners. At times, those who have claimed unique insight into ultimate reality have attempted to force their visions onto unconvinced masses, more often than not at a tremendous cost in human lives and wellbeing (the European heritage of the holy crusades, the Iberian Inquisition, the Conquista, and Social Darwinism in its most extreme forms-Nazism and Apartheid, to name but a few examples).

In Colombia's own recent historical experience, the Thousand Days War fought between Liberals and Conservatives at the turn of the century was the most bloody civil conflagration of the nineteenth century in the western hemisphere, costing an estimated 100,000 lives. Is it possible that ideas alone are capable of moving men to such horrific internecine violence?

Individuals view reality from their own perspective, shaped and molded by the particular socio-historical nexus that marks their lives and lifetimes. Though this may seem an obvious tautology to those who pride themselves in their command of the objective scientific method, the distorting affects of historically and socially-grounded biases are often discounted as being applicable only to non-scientists, individuals such as the ignorant "man in the street." Is it not likely that even the wisest mortal philosopher emerging from the cave of forms, in that first glance of daylight, is apt to view the colors and textures that constitute reality from the temporal and spatial perspectives that inextricably bind him to that particular historical instant?

In the current study, ideas, it will be argued, have the force to spur men to action only to the degree that the ideas reflect deeply entrenched social interests, which are 
themselves in turn closely tied to the existing socio-political system in place at a particular juncture in historical space. In other words, ideas serve as catalysts motivating action only when they are, or can be made to seem to be, socially, historically, and culturally relevant to individual or group perceived needs. The current chapter describes the methodological approach applied in this study and discusses the intellectual sources of that approach.

Among the most important sources that have influenced the author's view of the development of the Colombian labor movement are Charles Bergquist's excellent studies on rural laborers in Colombia. Bergquist's works are discussed in greater detail below. Also in the introduction is a detailed discussion of Marx's conceptualization of ideology's role in capitalist society, a conceptualization which has profoundly influenced the author's understanding of the powerful role of ideas in society. The work itself is not a Marxist or even a Marxian perspective. The historical determinism inherent in Marx, the imperative of the proletariat's historical liberating mission, inevitably convert Marxism itself into another ideology. Moreover, those since Marx who have tinkered with the original conceptualizations have all added their own perspectives to his. ${ }^{3}$ They have also added their historical, cultural, social, and personal biases.

The next section provides the reader with a brief overview of current literature on Colombian history covering the period under discussion as well as the most influential works that deal directly with the Colombian labor movement. It is followed by an overview of the methodological approach adapted in the present work.

\section{REVIEW OF THE RELEVANT LITERATURE ON COLOMBIAN LABOR}

Medofilo Medina has written a series of essays ${ }^{4}$ based on Rudé's works on the revolutionary crowd. 5 Other works that attempt to examine Colombian labor range from a polemical "education manual" to basic narrative. ${ }^{6}$

${ }^{3}$ See David McLellan's, Marxism After Marx (Boston: Houghton Mifflin Co., 1979) for an excellent introduction to the development of Marxian and Marxist thought after Marx's death. Other excellent syntheses of the influence of Marx on subsequent Marxian theoreticians include Sidney Hook's Marx and the Marxists: the Ambiguous Legacy (Princeton, New Jersey: Van Nostrand, 1955) and George Lichtheim's excellent historical perspective in Marxism: An Historical and Cultural Study (New York: Praeger Publishers, Inc., 1961)

${ }^{4}$ Medofilo Medina, La Protesta Urbana en Colombia en el Siglo Veinte (Bogotá: Ediciones Aurora, 1984).

${ }^{5}$ George Rude, The Crowd in the French Revolution (London, Oxford, New York: Oxford University Press, 1977).

${ }^{6}$ Marco A. Córdoba, Elementos de Sindicalismo (Bogotá: Ediciones Tercer Mundo, 1984) a primer 
The majority of works treating Colombian labor can be divided into three general camps, traditional political and labor historiography, intellectual histories and histories of ideas/ideology, and Marxist historical perspectives. Each in turn is reviewed in the following section.

Under the category of traditional histories, most writers have focused on providing a political analysis or economic analysis of Colombia's development, or in writing general or sector specific histories. ${ }^{7}$ A number of works which do not treat labor as their primary field of investigation can be grouped under the umbrella of traditional political analysis. Among these are included Robert Dix, Helen Delpar and James William Park's influential works on Colombia. ${ }^{8}$ Each of these touch upon labor in the context of its relation to the political system and the two traditional political parties. The primary focus of these works is on the historical development of the Conservative and Liberal Parties.

Another important historical work with a primarily political focus is Albert Berry, Ronald Hellman and Mauricio Solaún's collections of essays on the National Front era, Politics of Compromise: Coalition Government in Colombia. ${ }^{9}$ Essays in this volume

\begin{abstract}
covering the history, organization, and philosophy of the labor movement to be used by labor union members and leaders, and Miguel Urrutia, The Development of the Colombian Labor Movement, (New Haven, London: Yale University Press, 1969) Other perspectives will be discussed in greater detail in the body of the text below.
\end{abstract}

${ }^{7}$ Three general histories of labor in Latin America were also used as resources in the present work. They Include, Moises Troncoso and Ben Burnett, The Rise of the Latin American Labor Movement (New York: Bookman Associates United Printing Services, 1960); Victor Alba, Politics and the Labor Movement in Latin America (Stanford, Califomia: Stanford University Press, 1968), and; a three-volume history edited by Pablo González Casanova, Historia del Movimiento Obrero en América Latina (Mexico: Siglo Veintiuno Editores, 1984) Nearly half of Volume Three is dedicated to Colombia, the chapter entitled "El Movimiento Obrero Colombiano" written by Enrique Valencia.

${ }^{8}$ Robert H. Dix, Colombia: The Political Dimensions of Change (New Haven and London: Yale University Press, 1967) and The Politics of Colombia (New York, Wesport Conn., London: Praeger Publishers, 1987); Helen Delpar, Red Against Blue, The Liberal Party in Colombian Politics 1863-1899 (Alabama: The University of Alabama Press, 1981); and James William Park, Rafael Núñez and the Politics of Colombian Regionalism 1863-1886 (Baton Rouge and London: Louisiana State University Press, 1985). John W. Sloan's article "Regionalism, Political Parties, and Public Policy in Colombia," Inter-American Economic Affairs, 33 (3), (1979), pp. 25-46 also explores the political context of Colombia's fierce historical regionalism. Another influential work from a political perspective covering the period of "La Violencia" and the National Front includes Richard Maullín, Soldiers, Guerrillas, and Politics in Colombia (Lexington, Massachusetts, London: D.C. Heath and Company, 1973). Also see John D. Martz, Colombia: A Contemporary Political Survey (Durham, N.C.: The University of North Carolina Press, 1962). The most recent offering in this camp is the excellent study of artisan influence in early labor organization, David Lee Sowell's "The Early Latin American Labor Movement: Artisans and Politics in Bogotá, Colombia, 1832-1919" (Ph.d. Dissertation, University of Florida, 1986).

${ }^{9}$ Albert Berry, Ronald Hellman and Mauricio Solaún, Politics of Compromise: Coalition Government in Colombia (New Brunswick, New Jersey: Transaction, Inc., 1980). 
range from works dealing with the role of the Catholic Church, labor, and challenges to the coalition government by third parties to Solaún's excellent essay on the history of the Liberal and Conservative parties.

Influential economic works on Colombia are led by William Paul McGreevey's $A n$ Economic History of Colombia published in 1971.10 A number of recent works that have taken McGreevey as an important starting point for their own analyses focus more narrowly on the coffee industry. These include Colombian scholar Marco Palacios' work Coffee in Colombia, 1850-1970: An Economic, Social and Political History and Charles Bergquist's outstanding contribution to the field, Coffee and Conflict in Colombia, 18861910.11 An excellent critical review of these works and other recent sources on Colombian economic history has been published by William McGreevey in the Journal of Interamerican Studies and World Affairs. ${ }^{12}$ Bergquist's works will be discussed in greater detail below. Recent economic histories by Colombian authors include Zambrano's traditional liberal economic analysis and Kalmanovitz' ambitious work that was nearly fifteen years in the making, Economía y Nación: Una Breve Historia de Colombia. ${ }^{13}$ Although Kalmanovitz is influenced by both dependency theory and Marxism, his work does not fit neatly into either school. Trained as an economist, Kalmanovitz' study is basically a national economic history which treats the development of capitalism in Colombia, tracing its roots back to colonial times.

General histories of Colombia include the now classic, History of Colombia by Colombian authors Gerardo Arrubla and Jesús María Henao, written in an engaging, grand narrative style. ${ }^{14}$ Another intluential work which focuses on the modern history of

10William Paul McGreevey, An Economic History of Colombia (Cambridge, England: Cambridge University Press, 1971).

${ }^{11}$ Marco Palacios, Coffee in Colombia, 1850-1970: An Economic, Social and Political History (London, New York, New Rochelle: Cambridge University Press, 1980) Charles W. Bergquist, Coffee and Conflict in Colombia, 1886-1910 (Durham, N.C: Duke University Press, 1978).

${ }^{12}$ See William McGreevey's auticle "Reinterpreting Colombian Economic History," Journal of Interamerican Studies and World Affairs, Vol 23 No. 3 (August 1981). The article reviews the works cited in this study by Bergquist, Palacios, as well as recent offerings by other writers.

${ }^{13}$ Bernardo Tovar Zambrano, La Intervención Económica del Estado en Colombia 1914-1936 (Bogotá: Biblioteca Banco Popular, 1984) and Salomón Kalmanovitz, Economía y Nación: Una Breve Historia de Colombia (Bogotá: Siglo Veintiuno Editores, 1985).

${ }^{14}$ Jesús María Henao and Gerardo Arrubla, History of Colombia Translated by Fred J. Rippy. (New York: Greenwood Press Publications, 1969). The original Spanish edition was written in the 1930's. 
Colombia is Vernon Lee Fluharty's Dance of the Millions, Military Rule and the Social Revolution in Colombia 1930-195615. A number of well-known histories have been produced on individual sectors of the economy that focus on bananas, ${ }^{16}$ rural labor and the coffee industry, ${ }^{17}$ and a number of works also focus on the historical role of the Catholic Church in Colombian society. ${ }^{18}$

Perhaps the most important histories written to date that explore the intellectual history of Liberalism and Socialism in Colombia are those which have been written by Colombian socialist Gerardo Molina. His three-volume set exploring classical liberalism's roots in Europe in the nineteenth century to the welfarist orientation of modern liberalism in the 1930's and 1940's, has shed much light on not only the development of the Conservative-Liberal struggle, but also on the ideological complexities and differences among liberalisms principal advocates. 19 Like the three tomes on liberalism, his volume on

15 Vernon Lee Fluharty, Dance of the Millions, Military Rule and the Social Revolution in Colombia 1930-1956 (Pittsburg: University of Pittsburg Press, 1966). Also see J. Fred Rippy, The Capitalists and Colombia (Durham, North Carolina: 1931).

${ }^{16}$ Among works on the Banana economy include the classic study on the banana zone written by Charles Kepner and Jay Henry Soothill, The Banana Empire: A Case of Economic Imperialism (New York: The Vanguard Press, Inc., 1967) The Confederación Sindical de Trabajadores de Colombia has also produced a history entitled simply, Bananeras 1928-1978 (Bogotá: Ediciones Alcaraván, 1978).

${ }^{17}$ For good works on rural labor see Catherine LeGrand, "Labor Acquisition and Social Conflict on the Colombian Frontier, 1850-1936," Latin American Studies, Vol. 16, (1985);. Gloria Gaitán, La Lucha Por la Tierra en la Década del 30: Génesis de la Organización Sindical Campesina (Bogota: El Ancora Editores, 1984), and; Pierre Gilhodes, "Agrarian Struggles in Colombia," in Agrarian Problems and Peasant Movements in Latin America edited by Rodolfo Stavenhagen, (Garden City, New York: Anchor Books, Doubleday and Company, Inc., 1970).

${ }^{18}$ These include Daniel Levine's two excellent works, The Catholic Church in Venezuela and Colombia (Princeton, New Jersey: Princeton University Press, 1981) and a work produced in collaboration with A. Wilde, "The Catholic Church, Politics, and Violence: The Colombian Case," The Review of Politics, Vol. 39, No. 2, (April 1977). Also see J. Lloyd Mecham's book which is now regarded as a classic in the field, Church and State in Latin America (Chapel Hill, N.C.: University of North Carolina Press, 1934). Other works which focus on Church-state relations include David E. Mutchler, The Church as a Political Factor in Latin America (New York, Washington, London: Praeger Publishers, 1971); Frederick B. Pike The Conflict Between Church and State in Latin America (New York: Alfred A. Knapt, Inc., 1964); Richard Funk-Harries' Ph.D dissertation, "Camilo Torres Restrepo and the Christian Left in the Tradition of Colombian Church-State Relations," (Ann Arbor MI and London: University Microfilms International, 1980), and; Fernán González, Partidos Politicos y Poder Eclesiastico: Reseña Histórica 1810-1930 (Bogotá: Editorial CINEP, 1977).

${ }^{19}$ Two of Molina's three works on Colombian liberalism were utilized in the current study, including, Las Ideas Liberales en Colombia, 1915-1934 (Bogotá, Colombia: Ediciones Tercer Mundo, 1982) and Las Ideas Liberales en Colombia, de 1934 a la Iniciación del Frente Nacional (Bogotá, Colombia: Ediciones Tercer Mundo, 1986). There is a rich and varied literature on political and social thought in Latin America and Colombia, including the following works consulted in the present study: Harold Eugene 
socialism focuses on major ideological currents, in the history of Colombia, in this case tracing socialism's utopian roots in the nineteenth century to the modern socialist and communist parties. ${ }^{20}$ Also like his works on liberalism, Las Ideas Socialistas en Colombia focuses on the impact made by political parties, influential leaders, and writers.

The most influential book dealing with the Colombian labor movement is Miguel Urrutia's political history of labor, The Development of the Colombian Labor Movement. ${ }^{21}$ In Urrutia's book, labor is treated in a traditional manner characteristic of the U.S. industrial relations school, viewing labor as a partner (some view it as an equal partner, others as an important, but rather secondary tool of capital or factor of production) in the economic development of the nation. Explicit in this view is an overriding preoccupation with the harmonious coexistence of all groups in society and the inevitable prosperity of each guaranteed by an ever-expanding GNP inherent in a free-market economy. Anything that upsets this balance is deemed undesirable and actions and events which support harmony are deemed positive influences on the evolution of society. In Urrutia's story, progressive Liberals actively courted labor to help the party wrest control from the Conservatives and later to aid them in their bid to stay in power.

E.P. Thompson has called the temptation (which leftist scholars also often fall prey to) of reading history in light of subsequent "preferred" outcomes "Pilgrims Progress Orthodoxy". In a discussion of a 1919 historical event in Colombia, Urrutia reveals his ideological predisposition. Socialist intellectual leadership in a 1919 rally according to Urrutia carelessly led workers to needless violence as they displayed their "characteristic irresponsibility" (p. 63) and "recklessly sacrificed seven lives for no reason at all" (p. 64)

Davis, Latin American Thought: A Historical Introduction (New York: The Free Press, 1974), and his article, "Trends in Social Thought," in Man, State and Society in Latin American History, edited by Sheldon and Peggy Liss (New York, Washington, London: Prager Publishers, 1972); Leopoldo Zea, "The Struggle for Intellectual Emancipation," in Man, State and Society in Latin American History. Edited by Sheldon B. Liss and Peggy Liss (New York, Washington, London: Praeger Publishers, 1972); Sheldon B. Liss, Marxist Thought in Latin America (Berkeley, Los Angeles, London: University of California Press, 1984); Helio Jaguaribe, "Marxism and Latin American Development," in Marx and the Western World, (New York: Praeger Publishers, Inc., 1966); Eric J. Hobsbawm has written two relevant articles on ideology and the study of labor, one dealing specifically with the case of Colombia, "Labor History and Ideology," .ournal of Social History, 7 (Summer 1974) and "Ideology and Social Change in Colombia," in Ideology and Social Change in Latin America, edited by June Nash, Juan Corradi and Hobart Spalding Jr. (New York, London, Paris: Gordon and Breach Science Publishers Inc., 1977).

${ }^{20}$ Gerardo Molina, Las Ideas Socialistas en Colombia. (Bogotá, Colombia: Ediciones Tercer Mundo, 1987).

${ }^{21}$ Miguel Urrutia, The Development of the Colombian Labor Movement (New Haven, London: Yale University Press, 1969). 
while the railroad strike of 1919 , utilizing "the bargaining tactic of any national union" [those based on the U.S. model of collective bargaining] "illustrates the rationale and effectiveness of serious trade union activity." (p. 64) Though there is usually some validity to most approaches to social and historical analysis, as E.P. Thompson has written "My quarrel...is that [most approaches] tend to obscure the agency of working people, the degree to which they contributed, by conscious efforts, to the making of history.... Only the successful (in the sense of those whose aspirations anticipated subsequent evolution) are remembered. The blind alleys, the lost causes, and the losers themselves are forgotten."22

From the earliest political positions taken by the Communist Party in the 1930's to recent Marxist academic contributions, communist views of Colombian reality have been seriously flawed by two major problems. The first of these is that theoretical contributions from the left have focused almost exclusively on socialist and communist leadership or lack of leadership in the labor movement, and have looked almost exclusively at such areas as strike history, organized urban factory workers, workers in the banana zones, and worker protests in the nation's transportation sector.

As forcefully pointed out by Bergquist, their works ignore Colombia's primary link to the world capitalist economic system: coffee production. The few Marxist theoretical contributions that do address the coffee industry, such as Antonio García's pioneering Geografía económica de Caldas first published in 1937 and his later Gaitán y el problema de la revolución colombiana published in 1955, suffer from the second major flaw of leftist works: their strict adherence to an ideological framework that posits the inevitability of social revolution as the result of capitalist exploitation. ${ }^{23}$ In this, Marxist theoreticians also fall pray to the "Pilgrim's Progress Orthodoxy." As Bergquist comments, "Like Antonio García, most leftists have tried to make modern Colombian history appear to be more revolutionary than it is. They have applied pedestrian versions of universal social theory in a vain attempt to explain the twentieth-century history of a social formation whose singular structure and anomalous historical development cry out for original analysis." 24

${ }^{22}$ E.P.Thompson, The Making of the English Working Class (New York: Vintage Books, 1966), p. 12

${ }^{23}$ Both works are reviewed by Bergquist in his Labor in Latin America, In his Labor in Latin America: Comparative Essays on Chile, Argentina, Venezuela, and Colombia (Stanford, California: Stanford University Press, 1986) pp. 274-281, Charles Bergquist reviews the two major works of Antonio García, Geografía económica de Caldas (Bogotá: 1978, Second ed.) and his later Gaitán y el problema de la revolución colombiana (Bogotá:1955).

${ }^{24}$ Bergquist, Labor, pp. 280-281. In terms of other modern writers, the failure of Marxist historians such 
Three major contributions to the field of Colombian labor merit special attention. Though each has its unique perspective, these works all support the thesis that during the Liberal reforms of the 1930's and 1940's, labor was increasingly incorporated into the existing legal and political system by the Liberal state. They are Daniel Pecaut's Politica y Sindicalismo en Colombia, Victor Manuel Moncayo and Fernando Rojas' Luchas Obreras y Política Laboral en Colombia and Charles Bergquist's Labor in Latin America: Comparative Essays on Chile, Argentina, Venezuela, and Colombia. ${ }^{25}$ Each of these studies built on the work of its predecessor.

Daniel Pecaut's work, the first published among the trio, argues that labor's move towards Liberalism came about as a result of its gradual institutionalization by Liberal governments under the Revolucion en Marcha. Labor's incorporation into the social/political fold he argues, occurred as a result of labor's weaknesses and Colombia's relatively low level of industrialization.

Like the work of their predecessor, Victor Manuel Moncayo and Fernando Rojas' analysis focuses on the urban working class. Also like Pecaut, they are concerned with the labor legislation enacted during the Liberal governments of the 1930's and 1940's. The authors argue that the legal and political reforms undertaken by Liberal governments during these years reflected the ascendance of an industrial bourgeoisie. A major impact of the legislation was to channel working class protest into an institutional setting that could be readily controlled by the state. In the following statement, they elaborate on their position: "ese fenómeno sólo puede encontrar explicación en el interés de la clase captialista de ordenar y encuazar la lucha reivindicativa dentro de los parámetros del sistema capitalista, para evitar una confrontación real del mismo, o en la urgencia de producir un efecto

as Cesar Mendoza Ramos, who in the course of his work on the development of organized labor in Barranquilla to mention the expansion of banana and coffee exports that made the city's spectacular growth possible, instead focusing only on industrial development and industrial workers is common. For him, and other Marxists, only industrial workers make up "la clase obrera". See Ramos, Surgimiento y Desarrollo de la Clase Obrera en Barranquilla Paper presented at the Third Congress of Colombian History, Universidad de Antioquia, (Medellín, Colombia, November, 1981). Ricardo Sanchez, like nearly all Marxist historians, fails in his Historia Politica de la Clase Obrera en Colombia to appreciate the desire of campesinos to own and work their own land rather than farm on cooperatives, and fails to appreciate fully the attitude towards work and society brought to the early socialist movement by the highly influential independent craftsmen, (who by the way could not possibly buy into the idea of the liberating mission of the proletariat); Ricardo Sanchez, Historia Politica de la Clase Obrera en Colombia (Bogotá: Editorial la Rosa Roja, 1982). This tendency among Marxist writers obscures critical pieces of the socio-historical puzzle precisely because of these writers ideological predispositions.

${ }^{25}$ Daniel Pecaut, Politica y Sindicalismo en Colombia (Bogotá: Ediciones Culturales, 1982); Victor Manuel Moncayo and Fernando Rojas, Luchas Obreras y Política Laboral en Colombia (Bogota: La Carreta, 1978); and Bergquist, Labor. 
ideológico de legitimación política del sistema, o un efecto de control político de la lucha de clases para prevenir su agudización..."26

Moncayo and Rojas' arguments detour from Pecaut by making a plausible, yet not completely convincing case that the labor legislation passed during this era was the industrial bourgeoisie's economic interests writ into law. They contend that the legal and political structure erected by successive Liberal governments served to promote the economic interests of the industrial bourgeoisie and helped to secure the hegemony of this group over their class rivals (the landed gentry and the commercial bourgeoisie) and of course to consolidate its dominance over other classes in society. ${ }^{27}$

Legislation such as Law 83 of 1931, which gave unions the legal right to organize and regulated strike activity, is painted as an effort to institutionalize the labor movement in order to eliminate a potential proletarian threat to bourgeois rule. Overall, the long-term strategy of the Liberals, Moncayo and Rojas claim, was to allow unions to organize and obtain better worker benefits such as higher wages, which in turn would improve their purchasing power. The primary result would be the creation of a larger internal market for commercial goods produced by the industrial bourgeoisie.

It is debatable as to whether the industrial bourgeoisie had consolidated its hold on Colombian society by the 1930 's, especially given the disproportionate importance the coffee export sector still played in the economy. Though the "industrial bourgeoisie" may have been in the ascendency, many of the élites responsible for implementing the reforms were themselves tied to the export economy, including the individual who presided over the Revolución en Marcha, Alfonso López himself. ${ }^{28}$ Moncayo and Rojas unfortunately provide no evidence that the large landholders and exporters had developed an adversarial relationship with the industrial bourgeoisie, especially since it seems often times they were the same individuals. ${ }^{29}$

Nor is proof offered in terms of simple statistical data showing the number of industrialists vs. exporters serving in the Liberal governments of the 1930's and 1940's, nor does evidence appear on how the interests of a majority of those serving in government

${ }^{26}$ Moncayo and Rojas, Luchas, p. 33.

${ }^{27}$ See these arguments on pages 52 and 57.

${ }^{28}$ President López was the son of one of the most successful coffee exporters in the nation.

${ }^{29}$ See Robert Dix's discussion of the industrial bourgeoisie in The Politics of Colombia (New York, Wesport Conn., London: Praeger Publishers, 1987). 
might be advanced directly by promoting policies that favored industry over exports. It was after all, the domestic concentration of capital from coffee exports that had permitted the industrial expansion of the 1930's in the first place.

Another problem with Moncayo and Rojas' theory is the fact that the policy of industrialization had been launched by Conservative Rafael Reyes and accelerated by Conservatives during the "Dance of the Millions." Import substitution policies were also aggressively pursued by Liberal governments, and the tempo of industrialization was again stepped up by the Conservatives after the Liberals were defeated in 1946. If the Conservative and Liberal parties alike undertook policies favoring the growth of industry, under the argument advanced above, we would have to presume that the industrial bourgeoisie had gained a predominant position in both parties. Is that the case?

Unfortunately we do not know, since no analysis of the parties' élite composition is undertaken in their study. Could not a plausible alternative explanation be that the proindustry, import substitution policies were undertaken by modernizing élites from both parties who were anxious to develop their nation's economy, rather than a group of élites guilefully forging legislation responding to the narrow economic interests of the industrial bourgeoisie? Clearly both Liberal and Conservative governments alike favored industrialization, but there is no proof proffered to make a strong case that both parties, in a still highly regionalized economy, were responding to the narrow interests of an industrial bourgeoisie. ${ }^{30}$

Bergquist expands on the theses offered by Pecaut, Moncayo and Rojas, adding to their analyses the sector ignored by most scholars who write on the labor movement: rural workers laboring in the coffee economy. As Bergquist has forcefully argued in his studies of the Colombian coffee industry, "it is study of the organizational fate and political trajectory of workers in coffee production that gives unity to Colombian labor history and makes the larger story of national developments in the twentieth century comprehensible." 31

Bergquist's primary argument is that workers themselves have been powerful

${ }^{30}$ Indusurial activities were, and to a great degree still are, highly concentrated in Antioquia and Cundinamarca near the large cities of Medellín and Santa Fé de Bogotá, the nations capital. Today, Cali has also become an important manufacturing center. For a good discussion of Colombia's historical regionalism, see James Park, Rafael Núñez and the Politics of Colombian Regionalism 1863-1886 (Baton Rouge and London: Louisiana State University Press, 1985). For the modern period see, John W. Sloan, "Regionalism, Political Parties, and Public Policy in Colombia," Inter-American Economic Affairs, 33:3, (1979), pp. 25-46.

${ }^{31}$ Bergquist, Labor, p. 281. 
agents in shaping twentieth century Colombian history. One of the major shortcomings of modern Colombian labor historiography he asserts, is that, "Workers lacking organizational expression have seldom been studied. Social characteristics are frequently discussed in relation to strike demands, but not in the formation of a working class culture or consciousness." 32 Although he agrees with the basic premise offered by Moncayo and Rojas, that the Liberal reforms represented an effort by the élite to eliminate the threat from below, the threats in the two analyses come from different corners: Bergquist argues that the major threat to order and progress came from the possibility of a rural insurgency rather than an urban one. ${ }^{33}$

Coffee workers comprised the largest segment of workers in Colombian society up through mid-century. Petty agricultural production, especially coffee production, is highly individualist, competitive and driven by the profit motive. The relations of production in the countryside Bergquist holds, help define the parameters of the overall development of labor in Colombia. He writes, "The transformation of their struggle inevitably turn coffee workers against one another. After mid-century it left their class oppressors free to forge a new ideological and political consensus and successfully consolidate an industrializing peripheral capitalist order...As their own collective organizations languished, the unions of their early allies in the foreign-owned export enclaves and in transport and manufacturing industry were left exposed to the corporativist and repressive designs of the state." 34

Although Bergquist's intelligent, synthetic work is correct in asserting the importance of coffee workers in the development of a Colombian labor movement, by failing to address the role of the of artisan "working class" organizations in the late nineteenth and early twentieth centuries, as well as the competitive, independent, and "individualist" perspectives that craftsmen-turned-proletarians brought to the early urban labor movement, Bergquist misses an opportunity to establish a linkage between the shared organizational fate of workers toiling in coffee and working class organizations in the transport sector, banana plantations, oil fields, and early manufacturing industries. ${ }^{35}$ For

${ }^{32}$ Bergquist, Labor, p. 9.

${ }^{33}$ Bergquist, Labor, p. 313.

${ }^{34}$ Bergquist, Labor, p. 312 .

${ }^{35}$ Bergquist presents a carefully constructed, sophisticated analysis of the impact of the burgeoning coffee economy on Colombian politics and society in his Coffee and Conflict in Colombia, 1886-1910 (Durham, N.C: Duke University Press, 1978). A balanced review of Bergquist's Coffee and Conflict and Marco Palacio's Coffee in Colombia as well as other economic treatments of the development of 
Bergquist it seems, the failure of coffee workers to embark upon a radical path independent of the two traditional parties also sealed the fate of urban workers.

Both urban and rural workers chose to hitch their hopes and aspirations for a better life for themselves and their families to the rising and falling tides of the two traditional parties. Those same political parties were ruled by élites, or as the powerful upper class stratum is most commonly referred to in the Colombian context by national writers, los oligarcos. In order to understand the modern development of Colombian labor then, rather than exclusively treating forms of labor expression in the countryside or focusing narrowly on a burgeoning urban proletariat, a more holistic analysis should strive to integrate the dynamics of development of labor forms in each. Moreover, such an analysis should explore possible patterns in the country/city nexus such as formal and informal ties between urban workers, artisans and migrating sharecroppers, colonos and smallholders. ${ }^{36}$

The following section details the methodological approach to the study of the development of the Colombian labor movement which is applied in the present work.

\section{METHODOLOGY: OVERVIEW OF THE APPROACH}

Historians and other keen observers of social phenomena have not been immune to

Colombia's coffee economy can be found in William Paul McGreevey's "Reinterpreting Colombian Economic History," Journal of Interamerican Studies and World Affairs, Vol 23 No. 3 (August 1981). William Park, who addresses roughly the same period as Bergquist in his Rafael Núnez and the Politics of Colombian Regionalism 1863-1886 (1985) provides a critical treatment of Bergquist's work by offering a corrective regarding the role of regionalism, which is hardly touched upon in the latter's work. Unfortunately, Park commits the opposite error, overemphasizing the importance of regionalism and the influence of individual actors such as Nuñez and Caro in his antiquated "famous men" approach to Colombian history. He also oversteps the bounds of scholarly work by cavalierly dismissing Bergquist's outstanding analysis of labor relations in the coffee sector and misinterprets Bergquist's discussion of the rise and fall of Liberal fortunes as a rather simplistic, overgeneralized account characteristic of such a holistic approach. Bergquist's work is superior to Park's book on both theoretical and analytical grounds.

${ }^{36}$ While the current study addresses the development of forms of labor expression in both the city and the countryside, an in-depth analysis of informal and formal ties between urban workers and artisans on the one hand and campesinos and colonos on the other, including for example kinship ties, friendships, colleagues from prior work, or acquaintances, is an area critical to understanding the development of a modem labor movement. Although this area demands much further exploration, substantial demographic data on the vocational composition of the large-scale migrations that took place in the Colombian countryside during the late Nineteenth and first half of the twentieth century is non-existent (although some work on the early twentieth century has been done, such as McGreevey's "Urban Growth in Colombia," Journal of InterAmerican Studies and World Affairs, Vol. 16 No. 4 (November 1974)). Many migrants were campesinos driven in search of new land or larger parcels as a result of everdiminishing landholdings caused by division of family property through inheritance as well as encroachments by powerful hacendados. Many were also urban poor and artisans impoverished by their inability to compete with cheap foreign manufactures. All of these groups sought to resist proletarianization in the urban areas, many by staking claim to their own plots of land. Chapter Five looks more closely at labor in the countryside. 
the social, political and temporal biases that affect the individual's perceptions of social reality. "Historians," E. Bradford Burns writes in his study of ideology in Latin American historiography, "impose on society a perception of the past shaped by the topics they study, the values they hold, and their interpretations...the knowledge of the past which they handed down as history reflects their exclusive social position. In short, Latin America's written memory consists largely of a limited socially constructed reality."37 At first, such incisive observations might lead one to despair that a value-free, completely unbiased understanding of "reality" may be elusive. Quite pointedly, such an understanding does seem to be impossible, given the present state of intellectual and emotional development of our species and the limitations of our social sciences. How can individuals who seek to understand the past, and by implication, how that past relates to our present, gain insight into man's real or objective existence? If no social scientist is free from cultural and temporal-based biases, can a social "science" exist, and at the very least, is one able to articulate an operational definition of "objectivity"?

Immanual Wallerstein, perhaps the best known "world systems" theorist has remarked that, "in the present, we are all irremediably the products of our background, our training, our personality and social role, and the structural pressures within which we operate." For the honest observer of social phenomena then it must be acknowledged that absolute objectivity is unattainable: one can only hope to proximate objectivity by freely admitting such educational, cultural, temporal and spatial biases and move forward from there. Wallerstein is instructive:

The [scientist and scholar's] role is to discern, within the framework of his commitments, the present reality of the phenomena he studies, to derive from this study general principles, from which particular applications may be made...For the proper understanding of the present requires a theoretical comprehension that can only be based on the study of the widest range of phenomena, including through all of historical time and space. ${ }^{38}$

It is apparent that if one seeks to understand the social dynamics of any era of man's brief existence on this planet, one must, as Wallerstein suggests, look at the "widest range of phenomena," including the most elemental constituents of man's relationship to society: the patterns of social and economic organization prevalent in a particular historical

${ }^{37}$ Bradford E. Burns, "Ideology in Nineteenth-Century Latin American Historiography," Hispanic American Historical Review. 58:3, (1978), p. 409.

${ }^{38}$ Immanuel Wallerstein, The Modern World-System I (New York: Academic Press, 1974), p. 9. 
era and the individual's relation to those organizations. This is the approach taken in this study as a concerted effort is made to weave social, political, economic and historical information into a holistic framework.

One theoretical 'school' that has targeted as its primary field of inquiry an understanding of the relationships between ideas, individuals and society is the sociology of knowledge. Sociology of knowledge posits the existence of a direct relationship between the world of ideas and the existing socio-economic structures that help to define ideas in a particular society or era. This approach implies a search for the social origins of different modes of thought, origins ground in a "real", existential base. ${ }^{39}$

Karl Mannheim, one of sociology of knowledge's most important disciples, argued that it was necessary to understand those who advocated a particular system of thought, their social origins and the society in which the thought-system was developed. Mannheim believed that the intellectual can reveal to others the social origins of various systems of thoughts:

The principal thesis of the sociology of knowledge is that there are modes of thought which cannot be adequately understood as long as their social origins are obscured...the second factor characterizing the method of sociology of knowledge is that it does not sever the concretely existing modes of thought from the context of collective action through which we first discover the world in an intellectual sense...In accordance with the particular context of collective activity in which they participate, men always tend to see the world which surrounds them differently. ${ }^{40}$

Like the sociology of knowledge, the present approach argues that systems of thought must be understood in the social context in which they are born. ${ }^{41}$

${ }^{39}$ Of course, the socio-political structures of a particular era do not influence the creations of systems of thought in a one-way fashion, unidirectionally. There exists a dialectical relationship between ideas and social structure; ideas are not simply "formed" ex nihilo at a particular socio-economic juncture in history. Ideas may actively serve as agents influencing particular social events. For example, and this point will be argued more forcefully below, artisan support of the Liberal Party in the middle of the nineteenth century appears to be clearly at odds with their "real" economic interests, protection of their handicrafts from foreign competition. Nevertheless, the historical record indicates that artisans more or less consistently supported Liberal Party candidates throughout the second half of the nineteenth century. Marxist scholars have referred to a concept known as "false consciousness" to explain such seemingly inconsistent behavior. This concept will also presently be explored. At any rate, ideas clearly influence socio-political developments in a reciprocal, dialectical way.

${ }^{40}$ Karl Mannheim, Ideology and Uiopia (New York: Harvest Books, 1955), pp. 2-5. Quoted in Larry and Janice Reynolds, The Sociology of Sociology: Analysis and Criticism of the Thought, Research, and Ethical Folkways and Its Practitioners (New York: David McKay Company, Inc., 1970), p. 8.

${ }^{41}$ Good introductions to the sociology of knowledge include, Larry T Reynolds and Janice M. Reynolds, 
Classical Marxism's concern with the notion of ideology and how this concept relates to objective social reality makes Marx's work another theoretical source that offers insight into how ideas can be put to the service of various group or class interests. Although neither theoretical perspective is adopted wholesale by the author, the social, political and historical analysis presented is informed by both schools of thought.

More specifically, the present study utilizes the concept of ideology originally articulated in Marx's corpus. This concept is useful in terms of understanding how ideas relate to social reality in a given society, but ideology also has its explanatory limitations as will be discussed below.

\section{IDEAS AND SOCIAL REALITY}

The development of the concepts of alienation and self-estrangement in Karl Marx's work is often cited by modern defenders as powerful evidence of Marx's pronounced humanistic orientation to the study of society. In order to understand Marx's notion of ideology, it is necessary to review how the term relates to his conceptualization of alienation.

In the Economic and Philosophic Manuscripts of 1844, Marx argues that three conditions exist in capitalist society which transform labor into an alienated condition: first, the fact of private ownership of the means of production; second, as a consequence of the development of productive forces, a process of a division of labor arises and; third, human labor is transformed into a commodity. ${ }^{42}$

As a result, according to Marx, the concept of alienation has three main aspects: man's alienation from the object of his production; his alienation from himself during the activity of producing; and his alienation from his species-being, mankind, each of which are explained in the Manuscripts.

At the core of his theory of alienation lies an idea that constitutes a unifying theme throughout Marx's prolific theoretical output: the existence of private property ultimately hinders man's attempts to master his social and economic environment. The seizure of the

The Sociology of Sociology: Analysis and Criticism of the Thought, Research, and Ethical Folkways and Its Practitioners (New York: David McKay Company, Inc., 1970); James Curtis and John W. Petras, The Sociology of Knowledge: A Reader (New York: Prager University Press, 1972); and, Irving M. Zeitlin, Ideology and the Development of Sociological Theory (Englewood Cliffs, New Jersey: Prentice-Hall, Inc., 1968). The aforementioned article by Kurt Wolff also presents an excellent bibliography of sources, p. 59 .

${ }^{42}$ Karl Marx, The Economic and Philosophical Manuscripts of 1844 in Robert C. Tucker, The MarxEngels Reader (New York. London: W.W. Norton and Company, 1978) 
productive resources of society by the proletariat Marx believed, would free man to harness nature to his needs. Communism is the vehicle by which the emancipation of the workers from alienation could be achieved. Man for Marx, is in a process of coming-to-be. Through the abolition of private property, man can realize his true social nature and can ultimately transcend his self-alienation. ${ }^{43}$ The only way man can overcome alienation then is to seize the productive forces of society: this can only be accomplished when workers become conscious of themselves as a class distinct from other social groups within the social mode of production. For such a transcendence to occur, the proletariat must overcome an important obstacle to achieving such class consciousness--the distorting effects of ideology.

It is ideology, a (bourgeois) class-based distortion of reality, that is passed onto all men as truth. For Marx, it is this ideology that keeps the proletariat from recognizing its state of "false-consciousness" and prevents the working class from assuming its progressive role in the history of society. Marx writes, "Insofar, therefore, as [a particular class] rule as a class and determine the extent and compass of an epoch, it is self-evident that they do this in its whole range, hence among other things rule also as thinkers, as producers of ideas, and regulate the production and distribution of the ideas of their age: thus their ideas are the ruling ideas of the epoch." 44

We set out from real, active men, and on the basis of their real life-process we demonstrate the development of the ideological reflexes and echoes of this life-process. The phantoms formed in the human brain are also, necessarily, sublimates of their material life-process, which is empirically verifiable and bound to material premises. Morality, religion, metaphysics, all the rest of ideology and their corresponding forms of consciousness, thus no longer retain the semblance of independence. They have no history, no development; but men, developing their material production and their material intercourse, alter, along with this their real existence, their thinking and the products of their thinking. Life is not determined by consciousness, but consciousness by life. ${ }^{45}$

This statement represents an important departure from classical political philosophy as well as classical liberalism in that it posits that society determines man's nature rather than the other way around. Men's philosophical musings cannot be divorced from the

\footnotetext{
${ }^{43}$ Karl Marx, The Economic and Philosophical Manuscripts of 1844 Robert C. Tucker, p. 115.

${ }^{44}$ Karl Marx, The German Ideology, in Robent C. Tucker, The Marx-Engels Reader, p. 173.

${ }^{45}$ Karl Marx, The German Ideology, Robert C. Tucker, pp.154-155.
} 
historical moment and the particular society in which they are living.

Marx and Engels comment extensively on how bourgeois ideology manifests itself in their most popular work, the Manifesto of the Communist Party.

All objections urged against the communistic mode of producing and appropriating material products have, in the same way, been urged against the communistic modes of producing and appropriating intellectual products. Just as, to the bourgeois, the disappearance of class property is the disappearance of production itself, so the disappearance of class culture is to him identical with the disappearance of all culture.

That culture, the loss of which he laments, is, for the enormous majority, a mere training to act as a machine.

But don't wrangle with us so long as you apply, to our intended abolition of bourgeois property, the standard of your bourgeois notions of freedom, culture, law, etc. Your very ideas are but the outgrowth of the conditions of your bourgeois production and bourgeois property, just as your jurisprudence is but the will of your class made into a law for all, a will whose essential character and direction are determined by the economic conditions of existence of your class.

The selfish misconception that induces you to transform into eternal laws of nature and of reason the social forms springing from your present mode of production and form of property-historical relations that rise and disappear in the progress of production-this misconception you share with every ruling class that has preceded you. ${ }^{46}$

Even the polity is a creation of an epoch's dominant class. In his Critique of the Gotha Program, Marx describes his view of the state in an attack on the reformist-oriented German Workers Party: "Nevertheless, the different states of the different civilized countries, in spite of their manifold diversity of form, all have this in common, that they are based on modern bourgeois society, only one more or less capitalistically developed....in fact, by the word 'state' is meant the government machine, or the state insofar as it forms a special organism separated from society through the division of labor."47 Marx maintains that in capitalist society, the state reflects the "bourgeois mentality", a false consciousness which is produced by the constellation of social relations particular to capitalism. ${ }^{48}$ Liberal

\footnotetext{
${ }^{46} \mathrm{Karl}$ Marx, The Communist Manifesto, in Lewis S. Feuer, Marx and Engels: Basic Writings on Politics and Philosophy Garden City, New York: Anchor Books, Doubleday and Company, Inc. (1959) pp. 2324.

${ }^{47}$ Karl Marx, Critique of the Gotha Program, in Robert C. Tucker, The Marx-Engels Reader, pp. 537-538.

${ }^{48}$ See Marx/Engels section II. "Proletarians and Communists" in the Manifesto for their critique of
} 
political theory, which he so frequently denounces, is nothing more than an ideological justification for the existing property relations under capitalism. The state, and established political power in general, are viewed as merely the organized power of one class for exploiting another: "For each new class which puts itself in the place of one ruling before, it is compelled, merely in order to carry through its aim, to represent its interests as the common interest of all the members of society, that is, expressed in ideal form: it has to give its ideas the form of universality, and represent them as the only rational, universally valid ones." 49

In the course of the historical development of capitalism, the division of labor and private ownership of the means of production inexorably lead to class conflicts as workers begin to achieve a greater consciousness of their plight in bourgeois society. In order for the worker to overcome his alienated and exploited condition, he must overthrow capitalist society, just as the bourgeoisie had overthrown feudal society in order to create the capitalist mode of production. "Freedom," Marx proclaims, "can only consist in socialized man, the associated producers, rationally regulating their interchange with Nature, bringing it under their common control, instead of being ruled by it as by the blind forces of Nature and achieving this...under conditions most favorable to, and worthy of their human nature." 50

Social revolution will follow when the proletariat (the propertyless, working class) achieves a subjective and objective consciousness of its own exploited and alienated role in capitalist production: "...since all the living conditions of contemporary society have reached the acme of inhumanity in the living conditions of the proletariat; since in the proletariat man has lost himself, although at the same time he has both acquired a theoretical consciousness of this loss and has been directly forced into indignation against this inhumanity by virtue of an inexorable, utterly unembellishable, absolutely imperious need, that practical expression of necessity-because of all this the proletariat itself can and must liberate itself." 51

Although individual agents have a role in shaping society, since man cannot escape his environment, his culture, the legal and political system in which he was brought up, the

Bourgeois mentality, Robert C. Tucker, pp. 483-489.

${ }^{49}$ Karl Marx, The German Ideology, in Tucker, p. 174.

${ }^{50}$ Karl Marx, Capital Vol. III., Robert C. Tucker, p. 441.

${ }^{51}$ Karl Marx, Alienation and Social Classes, Robert C. Tucker, p. 134. 
influence of his family, and other influences that bind the individual to a historical and social epoch, historical imperative dictates that the proletariat must necessarily undertake its mission to serve as the catalyst liberating man from exploitation. Marx comments, "Men make their own history, but they do not make it just as they please; they do not make it under circumstances chosen by themselves, but under circumstances directly found, given and transmitted from the past. The tradition of all the dead generations weighs like a nightmare on the brain of the living." 52 Later he writes, "Communism is the position as the negation of the negation, and is hence the actual phase necessary for the next stage of historical development in the process of human emancipation and recovery." 53 Under communism labor will be abolished and man will find his true nature and engage in associated free production with other men. The final revolution is seen as a way to procure the permanent liberation of mankind from exploitation by other men. In the now famous lines of the Manifesto, Marx and Engels proclaim, "All previous historical movements were movements of minorities. The proletarian movement is the self-conscious independent movement of the immense majority, in the interests of the immense majority." 54

This was Marx's vague vision of the future. In a world where man was not fettered by "false consciousness" nor separated from the fruits of his labor and the company of other individuals by private property, man would transcend alienation and realize himself in the totality of social relations.

Such a "humanistic" interpretation of Marx is shared by several scholars including Robert Tucker, Sidney Hook, and George Lichtheim. ${ }^{55}$ Lichtheim argues that the possibility of man achieving a liberating self-consciousness is central to Karl Marx's theory of man and his relation to society. He writes:

The heart of Marxism (as of rationalism generally) is the belief that insight into the nature of reality is all that is required to release the forces making for the eventual triumph of liberty and rationality. Once men come to understand that the circumstances of their lives are opposed to the fullest development of human freedom, they will spontaneously strive to throw off these external constraints...The criterion [of moral conduct] is in the nature

${ }^{52}$ Karl Marx, The Eighteenth Brumaire of Louis Bonaparte, Robert C. Tucker, p. 595.

${ }^{53}$ Karl Marx, The Economic and Philosophical Manuscripts of 1844 Robert C. Tucker, p. 146.

${ }^{54}$ Karl Marx, The Communist Manifesto, Robert C. Tucker, p. 482.

${ }^{55}$ Robert C. Tucker, The Marx-Engels Reader; Sidney Hook, Marx and the Marxists: the Ambiguous Legacy (Princeton, New Jersey: Van Nostrand, 1955), and; .George Lichtheim, Marxism: An Historical and Cultural Study (New York: Praeger Publishers, Inc., 1961) 
of things, being nothing else but the principle of rationality which is the essence of all that is 'truly human'. To be rational is be in control of one's faculties. Such control is freedom, and its eventual triumph is the undisclosed aim of the historical process. ${ }^{56}$

There are a number of limitations in employing ideology as a central explanatory variable in social histories. Marx's assertion that the "ruling ideas of each age have ever been the ideas of its ruling class" must be considered carefully. Certainly powerful élite groups in society have a disproportionate influence in the creation and dispersion of ideas. At times it seems that such ideas do indeed help "mask" social reality and prevent certain social groups from achieving consciousness of their own position in society. However, "ruling" ideas do not seem to be the only ideas in society at a given moment in history, and the bourgeoisie has never been able to completely "regulate the production and distribution of the ideas of their age."

Although few would argue that the élite groups in nineteenth century Colombian society were less keenly aware of their privileged position in society than peasants and artisans, or that they did not view themselves as a special group apart from other strata in society, it must be realized that even the élite could make decisions and act in a manner contrary to their class interests. In the nineteenth century, the élite stratum of society comprised of a commercial, trade-oriented bourgeoisie and large landowners, may have possessed a consciousness of themselves as a class apart, but they were divided along lines of two competing ideological systems, neither of which were definitively adopted by the Colombian élite.

These competing ideological systems, each with a contrary view of the role of the church in society, laissez-faire economics and federalism, led to dozens of violent conflicts and numerous civil wars between followers of the Conservative and Liberal Parties.

Religion and federalism were particularly volatile issues, strongly influencing the actions of party leaders in the civil wars of the nineteenth century. These wars pitted élite against élite in an intemecine struggle that would appear to be contrary to the directing class' interest as a whole. Attempting to reduce such substantive issues as conflict over religion's role in society to pure economic interests is, in the Colombian case, an exaggeration.

It is true the Catholic Church was a major political player in Colombian society. It is also true that the Church in the early nineteenth century was also a major economic and social force, as will be explored in the Chapter Two of the present work. However

${ }^{56}$ George Lichtheim, Marxism, pp. 238-239. 
political support or condemnation of the church more often than not occurred along multiclass party lines rather than following strict class lines. Colombian peasants have traditionally been the most Catholic segment of society. Many artisans were also vehement in their defence of church interests, while others were not. The same holds true of the élite. Complicating the entire affair is the fact that nearly all Colombians considered themselves Catholic despite their position on the Church's role in society. Economic interests certainly played a role in Liberal efforts to limit the power of the church, but it can plausibly argued that such interests were simply an attendant feature, not the primary causal agent in the Liberals' actions. 57

Of course history is not stagnant, and inter-élite struggles did not remain a matter of Liberal free-traders vs. Conservative landowners. As Park points out in his study, there were landholders who were staunchly Liberal and there were Conservative exporters. At any rate, by the turn of the century, the free-trade issue had been definitively resolved in favor of libre cambio, both parties recognizing the critical importance of the coffee export trade.

In the twentieth century, a new division between the élite would emerge as Colombia began a march towards modernization, industrialization and urbanization, with the rise to preeminence of young, urban Liberals whose interests were not tied to the earth. As the mainstream of the Liberal Party adopted an interventionist view of the state's role in society, clamoring for greater rights for workers, the Conservative party moved in the opposite direction opting for repression. When finally in 1946 the Liberals decisively moved to choose pro-labor Gaitán as the Party's leader, the ideological gulf separating Conservatives and Liberals broadened. When Gaitán was assassinated less than two years later, party loyalties that had become hereditary both among élites and urban and rural workers exploded in La Violencia,.a civil conflagration that engulfed the nation and ended

${ }^{57}$ The argument that the Church's wealth in society represented one obstacle to rationalization of agricultural production and capital concentration necessary for the full development of capitalism has been advanced by Richard Funk-Harries in his Ph.D dissertation, "Camilo Torres Restrepo and the Christian Left in the Tradition of Colombian Church-State Relations," (Ann Arbor MI and London: University Microfilms International, 1980). Although undoubtedly nineteenth century Liberals wished to curb the influence and limit the wealth of the Catholic Church, I would argue that this came about more as an ideological imperative of following anti-cletical ideas adopted from Europe rather than as a rational class conspiracy to further bourgeois economic interests. For alternative interpretations to Funk-Harries see Daniel H. Levine's works, The Catholic Church in Venezuela and Colombia (Princeton, New Jersey: Princeton University Press, 1981) and "The Catholic Church, Politics, and Violence: The Colombian Case," The Review of Politics, Vol. 39, No. 2, (April 1977) which was coauthored with A. Wilde. Another source is David E. Mutchler's, The Church as a Political Factor in Latin America (New York, Washington, London: Praeger Publishers, 1971) and an unpublished manuscript by the author, The Catholic Church in Colombia: Implications for Development (1985). 
in the deaths of some 200,000 Colombians. If a consensus among the rulers that would guarantee their economic interests had been achieved, how could such a costly event in human as well as economic terms, pitting élite against élite and campesino against campesino occur?

It must be asked then whether it was false consciousness on the part of the landholders and/or bourgeoisie that kept them apart? Perhaps a lack of full consciousness of their dominant role in society left the ruling classes vulnerable from threats below, as in the Melo threat in 1852 or the socialist challenge in the 1920's. I will argue that profound differences stemming from competing views of an ideal society that separated Liberals and Conservatives dated back to early independence, and that residual "ideological" struggles helped keep Liberal élites and Conservative élites from achieving a full consciousness of their dominant position in society. This view is explored in the first two chapters.

It is not only that élites failed to achieve a full consciousness of their position in society, but it seems that both artisans and colonos both achieved a fairly high degree of consciousness of their differences at various stages in Colombian history. ${ }^{58}$ The Colombian peasant struggling to wrest a title to a parcel of land from a large landholder had a higher consciousness of himself, and his economic interests, as evidenced by the powerful desire to own his means of production, than has often been argued. This indicates an ability of both artisans and peasants to decipher at least partially their individual interests in society. This in turn has an impact on their acceptance or rejection of the ruling ideas in societies. For Colombian colonos, sharecroppers and small holders resisting proletarianization in the 1930 's, Liberal promises of land reform that would legalize their holdings had a much broader appeal than did Communist ideas about forming mass cooperatives in the countryside.

The communists' ideas on forming cooperative-based modes of production were themselves unsuccessful competitors in the world of ideas. Such ideas failed to motivate peasant and colono acceptance not merely because they were not the "ruling ideas" of the age, but because of their irrelevance to rural Colombian workers' views of themselves and their world. Colombian peasants were not merely "duped" by bourgeois ideology, they often simply pursued individualist strategies that at times significantly improved their life conditions.

Despite these difficulties with the Marxist conceptualization of ideology, the concept can have important explanatory power. In modern Colombian society, the predominant

\footnotetext{
${ }^{58}$ Chapter Five discusses the development of class consciousness and the artisans.
} 
ideology is created by that class, and is for a time accepted as truth: it has to give its ideas the form of universality, and represent them as the only rational, universally valid ones. In this study, ideology will refer to a set of political, economic and social ideas that are adopted by a particular group which attributes to this set of ideas the form of universality, representing them as a universally valid explanation of how the world works or should work. Thus classical liberalism, modern liberalism, and Marxism would count as ideologies, since each ideology's supporters generally attempt to offer them as universal truths, viable explanations of reality.

Although it is true that certain ideas gain wider acceptance than others in the open market of ideas, to continue the analogy borrowed from capitalism itself, certain groups in society have a much larger, more effective marketing division than others. To paraphrase Marx's argument that the ideas of the rulers are the ruling ideas of the age, one must admit that there is a great deal of validity in this proposition. It seems plausible that dominant ideas can be imposed surreptitiously by one social class as a result in a disparity in power, ie., control of media and most resources in society, and that such ideas can more easily be passed off as universal truth, than say the artisan "world view" of the early years of this century. ${ }^{59}$ However true this may be, as argued earlier, though ideologies can often obscure truth (false consciousness), they cannot long be accepted as truth unless something substantive in them can appeal to individual's economic, social or political interests. This is why the individualism, profit motive and rhetoric of equality and liberty, central tenets of liberalism achieved wide appeal among Colombian rural workers while socialized production and social solidarity of communism did not. The scholar's role should be to look at the ideas in society that influence men's and actions, seek out their social origins, and weigh their relative impact on individuals' lives and society as a whole, and in each case, strive to pinpoint the "masking effect" they may have on obscuring individuals' true interests.

The current study examines the development of the Colombian labor movement during the hundred years covering the period 1848-1948. In order to provide a substantive understanding of the growth of the Colombian labor movement, the present work seeks to: 1) provide an analysis of the particular space and time contexts of various intellectual/ideological productions that directly impacted the labor movement. This includes the social, cultural, political and economic milieu characteristic of a particular era, and the socio-historical processes that led to the creation of that era; 2) critically examine the

\footnotetext{
${ }^{59}$ See Chapters Four and Five of the current work.
} 
assumptions and beliefs held by principal actors in the process that marks the creation of various thought-systems and the dialectical interaction of these beliefs with other catalysts for action such as the economic conditions defining a particular time-frame (at what point do ideas "take on a life of their own" to serve as catalysts for actions of themselves, and how much of a role do they play in the overall scheme of things). Among such catalysts in the Colombian case are the motives and actions of Liberal and Conservative party leaders, labor leaders and spokespersons (journalists, pamphleteers, activists, etc.) and in some cases, third political party and international actors. Such a macro-level analysis as that which is being proposed implies the need to develop a theoretical framework based on the historical processes which led to the creation of the Colombian labor movement, as well as the dynamic interaction of the aforementioned actors which served (and, to argue at a later point, continues to serve) to maintain the structure of Colombian society, and; 3 ) provide a synthesis that links the empirical focus on contemporary socio-economic reality to an "objective" understanding of how the subsequent systems of thought, and actions, influenced the course of development of the Colombian labor movement; in short, provide the fit between theory and reality. Such an approach allows us to integrate each of these elements into a coherent, holistic analysis of the early development of labor in Colombia.

These three critical elements; the socio-historical context, the relationship between various actors and their ideas, empirical behavior, and ideology, and the synthesis that links these together will be utilized to provide us with a more objective, more complete understanding of the development of the Colombian labor movement than could be achieved through the study of historical or political events alone. In short, following Wallerstein's advice, the current study attempts to study "the widest range of phenomena" possible in the historical development of Colombian labor, including social, political and economic organization as well as the role ideas played in serving as catalysts to action.

This first chapter has provided a review of the relevant literature on Colombian labor and an overview of the methodological approach that will be applied to the study of the labor movement in Colombia.

Chapter Two sets the historical stage by providing an overview of the economic, social, political and philosophical situation in the colonial era focusing on how each of these areas impacted the later development of artisan organizations as well as the two principal antagonistic systems of thought in Colombia, Liberalism and Conservatism. Even though the study's primary focus is the hundred years between 1848 and 1948, in order to understand the critical developments of the nineteenth century, the economic and social legacy of Spain cannot be ignored. 
Chapter Three covers the nineteenth-century, focusing on historical events of midto-late century Colombia. It should be noted that several different considerations have led the author to limit the temporal span of the study to the period of 1848-1948 while providing a concise overview of important historical antecedents to the birth of an organized labor movement.

The first of these is the obvious constraint of time and space. In order to provide as thorough an examination as possible, given the limited resources which the author had to work, the project had to be narrowed to a realistic time frame. Secondly, although one does not witness the appearance of anything remotely resembling what may be termed an urban working class movement (one that was predominantly comprised of wage-earning workers) before the turn of the century, the influence of artisans in early urban labor organizations was critical. Highly politicized artisan worker organizations existed as early as the 1830's and the artisan sociedad democratica served as an important political force in mid-nineteenth century Colombia. Although the failed, largely artisan-led "revolution" of 1854 diminished the political clout of organized artisan "sociedades", artisans continued to be a social and political force throughout the nineteenth century, and later provided leadership and organizational skills to help build the first modern unions in Colombia. From the earliest stirrings of artisan activities in the new republic, both Conservative Party and Liberal were involved in the creation of artisan organizations to help support their ideological and programmatic positions.

Chapter Three explores the historical, economic and political trends evident in the nineteenth century. It focuses on the role of contemporary ideology-laden issues such as federalism, free-trade, and the place of the Catholic Church in society. The chapter also discusses the creation of the artisan sociedades democraticas under the ideological influence of liberal and conservative ideologies. Liberal ideology exerted a particularly strong influence over these organizations, and despite the fact that the organizations' charters proclaimed their non-partisanship, many adopted political stances supporting the Liberal government. This occurred despite the stark reality that the material interests of the artisans were diametrically opposed to the Liberals strong stand advocating laissez-faire economic policies. Free-trade, which would permit cheap manufactures from Britain and other parts of industrializing Europe to compete with local artisan production, ultimately could only serve to undermine the artisans' position in society. Chapter Three concludes by looking at the social gulf that separated artisan from élite and provides an overview of the affects of Liberal reform on artisan production.

Chapter Four, entitled "Utopian Socialism, Ideology and Class Conflict in the 
Nineteenth Century" takes a closer look at artisan "class consciousness" and the Liberal reforms of the 1850's and 1860's. It critically examines how the artisans viewed themselves and their role in society, as well as provides a self-portrait of Liberal party leaders. The gulf between Liberal principles such as liberty, brotherhood, and equality and the material interests of the élite-dominated Liberal leadership and their new-found Conservative allies, namely supporting free-trade legislation, is also drawn out along with the concomitant conflict with the leadership's former allies, the artisans. Events leading to the Melo dictatorship and the "Artisan Republic" of 1854 and the subsequent civil war that culminated in the collapse of the artisan rebellion are also discussed in Chapter Four, as well as the development of the apolitical artisan "mutualist societies" and the rise of an export economy in the latter half of the century.

While the early chapters of the thesis deal with the Colombian labor movement's historical antecedents in the nineteenth century, the last two chapters explore its development in the industrializing Colombia of the first half of the twentieth century. The appearance of modern industrial and craft unions had to await the gradual development of incipient manufacturing industries and advances in the transportation sector which accompanied the spectacular growth of the coffee trade. The closing decades of the nineteenth century witnessed the consolidation of a predominantly export-oriented coffee economy, resolving a longstanding conflict between the Conservative guardians of tradition and the Liberal, trade-oriented bourgeoisie.

Chapter Five, "Victory in Defeat: Consolidation of the Liberal Export Economy," looks at labor in the countryside while outlining the rise of the coffee export industry. The chapter looks at the country-city nexus, the struggle for land in the countryside and the rise of social conservatism and Rafael Nuñez. It also addresses the social and economic impact of the the War of a Thousand Days as well as the political implications of the separation of Panama.

Entitled "Early Industrial Growth and the Emergence of a Proletariat," Chapter Six explores industrial developments in the early twentieth century and the first concerted effort by organized labor to extract itself gradually from partisan politics. It also explores the economic impact of the "Dance of the Millions," the massive influx of capital as a result of the United States' indemnification for its role in the secession of Panama from Colombia.

Chapter Seven, "Labor and the Liberal Revolución en Marcha" discusses the reintegration of labor into partisan party politics. It describes the development of an influential group of "anti-élites", disaffected Liberals who became known as Los Nuevos, comprised of such intellectuals as Gabriel Turbay, Alberto Lleras Camargo and Jorge 
Eliecer Gaitan. The chapter explores the creation of new labor organizations, the Conservative government's repressive response to labor, the communists decision to ally themselves with the Liberals, and the influence Los Nuevos ultimately exerted on labor.

The chapter also reviews the events leading up to the creation of the Confederacion de Trabajadores de Colombia (CTC, the Confederation of Colombian Workers) in 1936, the first major agrarian reform in Colombia, Law 200 of 1936, and the strong support provided to organized labor by the Liberal government. This section argues that the government support which allowed unions to prosper was not without its costs: government "protection" also implied increased government control. The Liberal government subsidized several important union activities such as labor conferences and meetings. In 1937 however, the government exerted its considerable influence in labor affairs by passing a series of laws regulating union expenditures of government subsidies.

As had been the case throughout the nineteenth century, workers who had organized to fight for economic benefits in society to a certain degree became electoral pawns for the élite-dominated Liberal party. Despite Colombian "New Deal" reforms enacted under the Lopez Pumarejo administrations that in general helped improve the lot of the working man, predominant élite interests still dictated the course of societal changes in Colombian political and economic life. The Colombian élite realized the "inevitability of working class participation in the society and economy, while also hoping to channel it into controllable lines of action. 60

1948 was chosen as the terminal point for the present study for a number of reasons. In that year, the labor movement's Liberal champion Jorge Eliecer Gaitán was assassinated in the streets of Bogotá. This event was the major catalyst igniting one of the most intense and prolonged eras of civilian violence of the twentieth century, La Violencia. As a result of a number of factors discussed in greater detail in the thesis, labor witnessed a precipitous decline in its fortunes between the years 1946-1948. Although labor had sought a path independent of the two traditional parties in the first two decades of the twentieth century, it was clear that by the 1930's the majority of Colombia's laborers had been attracted to the Liberal Party Concomitant to the rise of a Conservative government in 1946 hostile to labor and its aspirations, could be seen the increasing influence of the Liberal Party, particularly Gaitán's disaffected faction, in organized labor's affairs.

60 Thomas E. Skidmore, "Workers and Soldiers: Urban Labor Movements and Elite Responses in 20th Century Latin America," in Elites, Masses and Modernization in Latin America, 1850-1930 edited by Bradford Bums and Thomas E. Skidmore (London, Austin: University of Texas Press, 1978), p 106 
Eventually, the labor movement which had strived to assert its independence at the turn of the century, would essentially be re-absorbed into the existing apparatuses of Colombia's two predominant political parties: Liberal and Conservative.

In late 1946, as the new Conservative government became less tolerant of the CTC, labor suffered a major setback. The dismal failure of a nationwide strike called by Colombia's largest and most powerful worker's organization, the Confederación de Trabajadores de Colombia itself, partly as a result of government repression, considerably reduced the likelihood of creating an effective labor organization independent of the traditional parties' interference and manipulation. Another blow to hopes for an autonomous union movement was the establishment of the Jesuit-organized Union de Trabajadores de Colombia (UTC; Colombian Worker's Union), in 1946 which, in the words of Colombian historian Paul Oquist, "became the favored instrument of the Conservative government." 61 All of these events served to weaken, and eventually, to undermine an already vulnerable nascent labor movement. With the onset of the anarchical period in Colombian history known as La Violencia, laborers in Colombia had completed their first hundred years of servitude.

The final chapter, Chapter Eight provides a conclusion, implications for future research and a summary of the main lines of argument. This chapter also provides a brief assessment of organized labor's impact on Colombian society and politics during $\mathrm{La}$ Violencia, relating labor's influence, or rather lack of influence, to earlier events.

No matter how committed, knowledgeable and relatively unbiased an observer from the late twentieth century may be, it is obviously impossible to view early nineteenth century labor history through the eyes of those who lived through and created it. There is the testimony of the contemporary press, official party organs and leaders, some sketchy economic data for the period under consideration, the artistic legacy of writers, poets, and even politicians and records on laws passed by the Colombian legislature. Despite this drawback, the present study represents a conscientious effort by the author to bring to light the limited information that does exist on how workers actually viewed themselves and their society.

One cannot however, uncritically accept the contemporary testimony of eyewitness observers either. It must be remembered that the actors themselves were part of the environment that they were observing. Each actor viewed his world from the context of his

61 Paul Oquist, Violence, Conflict and Politics in Colombia. (New York, Toronto, San Francisco: Academic Press, 1980), p. 113. 
social vantage point, and in many ways such a vista is more biased than a contemporary social scientist's account may be. A profound gulf separates an individual's perceptions of his own motives, actions, society, and world-view and an 'objective' understanding of social reality. Law 200 of 1936 was the Liberal López Pumarejo administration's answer to peasant demands for land: it represented one of the first attempts at authentic agrarian land reform in modern Latin American history. Left-wing and moderate Liberals alike viewed the legislation as a mechanism to clear up disputed title to lands claimed by peasants and large landowners in favor of the former, but the historical record indicates that the Liberals' good intentions conflicted with the actual social outcome. Law 200 was devastating to the small independent landholder since in actuality, it sanctioned many of the large landowners property claims and led to the legal eviction of thousands of peasants. ${ }^{62}$

One task of the historian therefore, is to attempt to go beyond the primae facie evidence afforded by the actors' idealized visions of themselves, in an effort to strip away ideological garments and gain a more accurate view of the social reality beneath the façade. To do this, one must once again seek to understand how and why such self-assessments are produced in a particular society at a particular time. This evidence must be weighed against other variables such as the socio-economic position of the agent, possible political ramifications of the the agent's professed views, and how such "professed" views may vary from actually held beliefs. One must also take into account the context of the sociotemporal locus impacting the individual's perspective, and the social actor's class affiliation and loyalties.

One problem for the student of labor history who is primarily limited to secondary sources, is a strong reliance on the more traditional sources on union organization and leadership, strike history, and government responses to labor's challenge. Nevertheless, while acknowledging this limitation and those described above, the work will attempt to view the available data and resources with a critical eye on the theoretical perspectives and social backgrounds of the authors in sources utilized in the study, the social and educational baggage each writer brings to the task and any biases possessed by the author of this work as a result of his personal background.

Finally, the present study does not pretend to be an exhaustive historical analysis, but rather seeks to provide a preliminary framework for a discussion of the early development of the Colombian labor movement.

${ }^{62}$ Catherine Le Grand, "Labor Acquisition and Social Conflict on the Colombian Frontier," Latin American Studies, (Vol 16, 1985), p. 45, and Paul Oquist, Violence, p. 98 make this point forcefully. 


\section{CHAPTER 2}

\section{COLONIAL COLOMBIA}

Because of the excessive liberty the Indians have been permitted, they flee from Christians and do not work. Therefore they are to be compelled to work, so that the kingdom and the Spaniards may be enriched, and the Indians Christianized. They are to be paid a daily wage, and well treated as free persons for such they are, and not as slaves.

Royal Order of December 20, 1503 laying the

legal foundation for the encomienda system. ${ }^{1}$

...the king has sent ecclesiastics who have taught the Indians the Christian doctrine and faith by which they could be saved. Moreover, the king has established justice in such a way that no one may aggravate another. The king has maintained the peace so that there are no killings or sacrifices, as was the custom in some parts. He has made it possible for the Indians to go safely by all roads and to peacefully carry on their civil pursuits. He has freed them from burdens and servitude; he has made known to them the use of bread, wine, oil and many other foods, woolen cloth, silk, linen, horses, cows, tools, arms and many other things from Spain; he has instructed them in crafts and trades by which they live excellently. All these advantages will those Indians enjoy who embrace our Holy Faith and render obedience to our king.

Royal Ordinance of July 13, 1573

Promulgated by Philip II ${ }^{2}$

\section{INTRODUCTION}

One may wonder why a late nineteenth/early twentieth-century exploration of the labor movement begins with the colonial period. In order to understand the critical developments of the nineteenth century, the economic and social legacy of Spain cannot be ignored. Professor Gerardo Molina pointedly addressed this issue in the most recent of his several social histories of ideas in Colombia, Las Ideas Socialistas en Colombia:

"La dominación hispánica en estas colonias fue una potente maquinaria de creación de desigualdades...todos los factores se conjugaban en la Península para oprimir al pueblo: una monarquía absoluta, una nobleza que se creía de origen superior, una Iglesia cada día más ansiosa de intervenir en los asuntos terrenales, unos propietarios de tierras que se comportaban en

${ }^{1}$ Quoted in Lewis Hanke, The Spanish Struggle for Justice in the Conquest of America (Boston: Little Brown and Company. 1949), p. 20.

${ }^{2}$ Hanke, The Spanish Struggle for Iustice, p. 131. 
sus respectivos feudos como reyezuelos, todo esto conspiraba contra las gentes del común."3

Unlike Anglo colonial aspirations in North America, the Spaniards were drawn to the New World in search of two driving and complementary concerns: the pursuit of economic wealth and the conversion of the indigenous peoples to Roman Catholicism. With the conquering warriors came their visions of a medieval world-view which melded the cross of Peter with the sword of Caesar. Whether for the sacred goals of religious conversion or the more profane desire for economic exploitation, as Colombianist Robert Dix has remarked, either of these cases implied domination over the native population. ${ }^{4}$ The following section explores how this relationship developed and how it impacted the development of Colombian society.

\section{THE CROSS AND THE CROWN}

1492 is remembered by American schoolchildren as the year that Columbus set sail for the New World. In Spain however, the year is also significant for another important event: Spain achieved national territorial integration in 1492 by driving the Moors from the Iberian Peninsula. Militant religiosity supplied a cohesive force that made possible Spain's zealous drive toward nationhood, and in turn helped to cement the bonds of church and state characteristic of Spain. Later, this relationship would be transplanted in the colonies and become a defining characteristic of the emerging Hispanic nations of the Americas.

In the New World, the Crown and Church undertook complementary missions. As Fernando de los Rios eloquently wrote fifty years ago in his Action of Spain in America:

Spain was impelled to two kinds of militant action at that momentous period of her history: the one militarist the other spiritual, both combative and eager to conquer; in the former the purposes to conquer power, territory, and riches prevailed; in the latter the prime aim was to win adherence to Christianity. [That] there was an interweaving between the two...each of which depended for its existence on absorbing a part of the vital juice of the other, is quite fundamental for the understanding of Spanish colonization. The will to power and the will to imperium, in the double dimension so

${ }^{3}$ Gerardo Molina, Las Ideas Socialistas en Colombia (Bogotá, Colombia: Ediciones Tercer Mundo, 1987), p. 35 .

${ }^{4}$ Robert Dix, The Politics of Colombia (New York, Wesport Conn., London: Praeger Publishers, 1987), p. 14. 
loved by the Renaissance, material and spiritual, reached through Spain to its apex. ${ }^{5}$

Under Isabella, Spain became much more receptive to influences emanating from the Renaissance which had earlier taken root in other parts of western Europe. Long established as a major portal to knowledge held in the Islamic world, much of the rediscovery of the ancient classics had initially been transmitted to the rest of Europe through the Iberian Peninsula. Spain's and Portugal's energies in the fifteenth century however, had focused on conquering and consolidating territory in the Iberian peninsula long held by the Moors. Many of those who had served as conduits to bring the classics to Europe were Jewish and Islamic scholars who lived in Spain. During the Inquisition, most Jews and Muslims fled Spain, while those who remained had their lands expropriated, were subject to trials for crimes of heresy in ecclesiastical courts, and many were put to death. Spain lost its role as portal to Europe for the transmission of knowedge held in the Islamic world, while the rediscovery of classical knowledge had a profound and lasting impact on the rest of Europe: the great explorations, the rise of mercantilism, the beginning of the consolidation of territories into powerful nation-states and the renaissance forever transformed European societies.

Once Spain had been unified however, the Islamic threat began to recede in importance. ${ }^{6}$ Ideas and events in the rest of Europe began to have a much more pronounced impact on Spain. In his history of the era of reconnaissance, J.H. Parry writes of the changes in Spanish outlook wrought by increased contact with the rest of Europe:

With a new attitude towards the individual, the Renaissance fostered a new attitude towards the State, also Italian in origin. A sensitive new alertness, a studied, objective attention to the most effective and most elegant means of achieving a desired end tended to supplant the older notion of the State as a network of fixed, traditional rights and duties over which the monarch presided as a judge of disputes...Like many Italian rulers, Isabella of Castile owed her throne to a mixture of war and diplomacy. A masterful restoration of public order and discipline was one of her major achievements...Machiavelli's principles of statecraft had no more successful exemplars than Ferdinand of Aragon and John II of Portugal...It helped

5Fernando de los Rios, "The Action of Spain in America," Concerning Latin American Culture (New York: 1940), pp.-25-78, quoted in C.H. Haring's The Spanish Empire in America (New York: Harcourt, Brace \& World, Inc., 1946), p. 166.

6 The omnipresent threat of the Ottoman Turks in the eastern fringes of Christendom, ensured that in Spanish eyes the threat would remain a real one as long as political Islam remained a dominant force in world affairs. During the Inquisition, Moslems and Jews alike were coerced into converting to Christianity or were expelled from Spain or killed. 
prepare men's minds for the immense tasks of political and administrative improvisation which was to confront Spanish government in the New World. ${ }^{7}$

As has been underscored by generations of historians, the spiritual mission of the Catholic Church has also had a profound moral, intellectual and economic influence on the historical development of Latin America. ${ }^{8}$ Beginning with the Cardinal Ximénez Cisneros' reforms encouraged by Ferdinand and Isabella, successive Spanish monarchs encouraged the symbiotic relationship between Church and state to flourish. Charles $\mathrm{V}$ and Philip II gradually came to acknowledge the authority of the Pope in spiritual matters ${ }^{9}$. The Papacy, the other half of the alliance, at one point provided the Spanish Crown with a considerable source of income; one account estimated that some $20 \%$ of Philip II's revenues derived from the Church. ${ }^{10}$

From the outset of the conquest however, the Church came under the direct control of royal authorities in all matters except doctrine and royal discipline. The Patronato Real de las Indias defined the Church's relation with the Spanish Crown. Based on a series of Papal Bulls, the Patronato Real, as the body of royal privileges vis à vis the Church was to become known, ceded authority to the Crown to appoint church personnel, as well as the right to make decisions affecting the establishment of churches, monasteries, hospitals and missions in the New World. Universalis Ecclesiae, the bull of Julius II dated July 28th, 1508 , is cited by Mecham as the "principle documentary evidence of the Spanish

7J.H. Parry, The Age of Reconnaissance: Discovery, Exploration, and Settlement 1450 to 1650 (London: Weidenfeld and Nicolson, 1973), pp. 32-33.

${ }^{8}$ Many of the works utilized in this study allude to the power of the Church, including, C.H. Haring The Spanish Empire in America (New York: Harcourt, Brace \& World, Inc., 1947), Lewis Hanke, The Spanish Struggle for Justice in the Conquest of America (Boston: Little Brown and Company. 1949), J.H. Parry, The Age of Reconnaissance: Discovery, Exploration, and Settlement 1450 to 1650 (London: Weidenfeld and Nicolson, 1973), Jesús María Henao and Gerardo Arrubla, History of Colombia Translated by Fred J. Rippy. (New York: Greenwood Press Publications, 1969), Robert Dix, The Politics of Colombia (New York, Wesport Conn., London: Praeger Publishers, 1987), and of course, the studies focusing on the role of the Catholic Church in Colombia, David E. Mutchler, The Church as a Political Factor in Latin America (New York, Washington, London: Praeger Publishers, 1971), and Richard Funk-Harries, "Camilo Torres Restrepo and the Christian Left in the Tradition of Colombian ChurchState Relations," Ph.D dissertation (Ann Arbor MI and London: University Microfilms International, 1980).

${ }^{9}$ Richard Funk Harries, "Camilo Torres," pp. 94-101.

${ }^{10}$ Funk-Harries, "Camilo Torres," p. 101. 
sovereigns to exercise jurisdiction over the Catholic Church in Latin America."11 In return, the Church imposed upon the Crown the obligation of Christianizing the natives and implanting Spanish civilization in her American domains. In practice, the kings of Spain wielded tremendous authority over the church in America: the Crown had the right to set the limits of dioceses, control administration of ecclesiastical taxation, and to nominate archbishops, bishops and abbots.

In Colombia the Crown and Church were especially successful in the proselytizing aspect of their mission. To this day, the Roman Catholic Church in Colombia is often described as one of the most conservative, orthodox and powerful churches in Latin America. Historian Lloyd Mecham for instance, has written that the Church has been "more tenacious in its hold upon national and civil life in Colombia than in any other LatinAmerican country." 12 Despite challenges throughout Colombia's history to its prominent role in society, the Church has maintained a great deal of influence in public life through the virtual monopoly of various sectors in society: the educational system, charity and welfare activities, hospitals and asylums.

In colonial days, as well as during the post-independence, neo-Bourbon era, the influence of the Church pervaded every aspect of social life. The birth of a child was celebrated with baptismal in the Church and an entry into official records kept by the local parish. When one took a mate, this too was marked by a religious ceremony conducted by a man of the cloth. And when finally a life came to an end, even death remained within the sovereign realm of the Church: an individual was laid to rest with a vesper to God and his memory recorded in a parish passage.

In a deeply religious society, the power to excommunicate represented the power of spiritual life and death over individuals not only in this world, but also in the next. The ability to excommunicate gave the Church significant power over agents of the state. If not quite an equal partner in terms of power in the New World, the Church was nevertheless the central agent in bringing Spanish customs and laws to the indigenous peoples and in maintaining the standards of the faith among colonist and conquistador alike.

And finally, the Church, as a result of its close bonds to the Spanish Crown, served in many respects as an extension of royal government in the colonies. In supporting Spain's claims in the Americas, Rome thereby provided legitimacy to Spanish imperial

11J. Lloyd Mecham, Church and State in Latin America (Chapel Hill, NC: 1934), p. 16.

${ }^{12}$ Mecham, Church and State, p. 115. 
rule. The tremendous political and social power devolved to the state through the Patronato Real implied an indivisible union of Church and state in which the latter was preeminent. Because of the extensive royal authority exercised under the Patronato Real, the Church in the Americas was to become a national church, "living within the orbit not of the Roman Papacy but of the Council of the Indies, and attached to Rome by very tenuous bonds." 13

The fact that the Church may have been politically controlled by the state does not diminish the tremendous influence the clerics exercised at home in shaping the direction of Spanish policy in the Americas, nor its profound influence on the daily life of the colonies' peoples, both Indian and Hispanic. Most clergy came to the New World with unswerving belief in their faith, authentic dedication to their proselytizing mission, and a strong sense of commitment not only to the crown but also to the tenets of the Holy Roman Catholic Church. The spiritual mission of the Church complemented its secular mission of maintaining the social welfare of the colony, which aided the Crown to extend its power and authority in America. As many historians have noted, during the colonial era, the Catholic Church became "the most powerful single agent for inculcating the lessons of obedience and loyalty to the person of the monarch among all classes of society." 14

\section{THE COLONIAL ECONOMY}

Since the primary allure of the New World for the Spanish Crown and subsequently, for the early conquistadores, was the pursuit of precious metals, the initial economic focus was placed on exploiting the generous gold and silver resources of the Americas. These resources were needed to finance Spain's colonial ventures, her political and territorial aspirations in Europe, and most importantly, to help pay for manufactures imported from northern Europe.

In terms of the colonial society's link to the Old World's economy, it has been argued that the early colony could be described as a form of transplanted feudalism inserted into a European-centered mercantilist world economy. Colombian economic historian Salomón Kalmanovitz has encapsulated the nature of the colonial economy in the following terms:"...podemos deducir que las formas de producción en el virreinato de la Nueva Granada, base de la nación Colombiana, corresponden, de manera por demás aproximada,

${ }^{13}$ C.H. Haring The Spanish Empire, p. 169, paraphrasing Desdevises du Dezert, L'Eglise espagnole des Indes à la fin du XVIIle siècle (Paris: 1917).

${ }^{14}$ Funk Harries, "Camilo Torres," p. 115. Virtually every text on colonial Spanish America alludes to this fact, including each of those referenced in footnote 8 . 
a una etapa elevada del desarrollo social del feudalismo; sus antecedentes aborígenes, su situación colonial y la etapa en que se hallaba el capitalismo en el mundo y que se proyecta sobre la producción y la evolución política, le prestan características propias a la estructura productiva y a las instituciones que la acompañan" 15

It is not surprising that the Spanish would seek to establish a social and economic system that was at once consistent with their experience at home and also aimed at the optimum utilization of existing human resources in the territories they conquered. In her new possessions in the Americas, particularly New Spain (Mexico) and the Peru, and Nueva Granada rich deposits of silver and gold were discovered and brought into production with the rudimentary mining technology known to the Spanish. The mines were exploited with the labor initially provided by the indigenous peoples of the New World.

Successful in their quest to subdue the major urban centers of Indian America, the conquistadores did not completely destroy the social organization that they discovered: in most cases, in the early years of colonization, they merely replaced the tribal chieftains and priests who had preceded them. For villagers long accustomed to paying tribute to the Inca, the Maya or the Aztec Empires, the transition to European rule was probably not as traumatic as one might suppose. ${ }^{16}$

In Colombia, the Spaniards did not encounter an empire of one dominant group such as the Aztec of Mexico or the Inca of Peru, but instead found many different tribes varying in their degree of social complexity. On the sabana of Bogotá, which included the later provinces of Tunja and Popayán, the Spanish took advantage of the relatively large, sedentary populations such as the Muiscas that they discovered there, by appropriating a portion of the Indians' production and also by using indigenous labor to construct colonial churches and towns. ${ }^{17}$ In other areas, notably Antioquia, Santander, and Tolima, more warlike tribes resisted the Spaniards and were largely eliminated. These regions were also magnets for many Spanish colonizers in 17 th century. ${ }^{18}$

\footnotetext{
${ }^{15}$ Salomón Kalmanovitz, Economía y Nación: Una Breve Historia de Colombia (Bogotá: Siglo Veintiuno Editores, 1985), p. 91.

${ }^{16}$ The exceptions were non-sedentary tribes that resisted the Spaniards and of course, the caciques and priests who were replaced.

${ }^{17}$ Kalmanovitz, Economía, p. 16.

${ }^{18}$ Kalmanovitz, Economía, p 16.
} 
Although comparisons are often drawn between European feudalism of the middle ages and the economic system established in the New World, as Kalmanovitz correctly notes in his economic history of Colombia, despite many parallels, the forms of production which were implanted and took root in the Americas were significantly different. ${ }^{19}$ Encomienda, as the economic system which initially developed in the Spanish colonies was known, was based on a royal concession of labor apportioned to the conquerors. In return, the encomendero was charged with the moral and religious instruction of the Indians. In reality, Indians were often enslaved, to work at the will of the encomendero, even though Royal Orders as early as the celebrated 1503 decree expressly prohibited enslavement of the native peoples. Indians provided labor to build Spanish churches and towns, to harvest and transport food for the Spanish settlers, and to work the mines to provide the colonists with silver and gold to purchase European-produced goods. The encomienda was the predominant early form of labor recruitment in Spanish domains in the Americas, and remained an important economic force for nearly two and one-half centuries.

Shortages of grain staples in the late sixteenth century led to widespread cultivation of wheat on Spanish latifundia, which had grown up out of territories purchased or bribed from local caciques. Despite strict legislation aimed at preserving Indian village-holdings, such means of accumulating property were quite common. The rapid growth of these large scale feudalistic seigniorials in the seventeenth century had the effect of reducing traditional communal forms of agriculture that had been practiced by many Indian cultures before the arrival of the Spaniard.

The foundation upon which the colonial economy was established, Indian labor, began to erode soon after it was established, although not the direct result of the internal logic of the encomienda system. European diseases to which the native population had no immunity, chronic overwork, and damage done to food crops of Indians by grazing cattle and sheep rapidly decimated the Indian labor force. In Mexico alone, one fairly typical estimate shows the following decline in population between 1519 and the end of the

${ }^{19}$ Kalmanovitz, Economia. pp. 88-89. Among the salient differences noted by Kalmanovitz include the existence of forced labor and the mita in the Americas which had no parallel in medieval Europe; labor mobility in America was much less restrictive than in the fiefs of the middle ages' nor were the Indians and mestizos in need of seignorial protection against invading outsiders; in Nueva Granada most villages were formed by smallholders and independent renters rather than by tenants of feudal overlords' landholdings, and; in addition to a greater physical mobility, trade was much freer between different regions, eg. between the agricultural and mining districts and, towards the end of the eighteenth century among the viceroyalties. This relatively freer trade in Nueva Granada (despite the considerable physical obstacles the Andes Mountains) is contrasted to the territorial sovereignty of feudal domains, sovereignty that interfered with trade and labor mobility. 
sixteenth century: $1519-11,000,000 ; 1540-6,427,466 ; 1597-2,500,000 .{ }^{20}$ Other regions of Spain's empire in the Americas also witnessed a precipitous decline in the Indian population, including the area which encompasses present-day Colombia. By the seventeenth century, Kalmanovitz estimates that the population of indigenous peoples in Colombia stood at a mere 15 to 20 percent of what it had been at the time of the conquest. ${ }^{21}$ At present, less than five percent of Colombia's population is considered native Indian.

European diseases claimed the greatest number of lives, but overwork and cruelty to Indian workers also took their toll. Particularly notorious during the colonial period was the frequent mistreatment of Indian workers in the obrajes, the small-scale woolen industry which supplied much of the colonies' textiles, as often by local caciques as by Spanish overlords. Fourteen-hour workdays, except in the mines where the actual working day was longer, kept Indians away from their villages and their own fields. ${ }^{22}$ Kalmanovitz writes the following on the cruelty in Colombia, "los españoles redujeron salvajemente el nivel de consumo de las sociedades aborígenes, pero a la vez les impusieron ritmos de trabajo tan duros y desacostumbrados, que el excesivo aumento de las faenas atentó contra la reproducción biológica de los pueblos hallados por los civilizadores cristianos." 23

Although the encomienda system was not legally abolished in Colombia until 1832 by José María Obando after independence, as the colony grew, this form of economic organization increasingly became inadequate as the pace of migration from Spain quickened and the number of encomiendas available were rapidly reduced. The encomienda system primarily benefitted the few to whom Indian labor had been granted by royal authority In a royal effort to dismantle the system with a minimum amount of political outcry by the powerful existing encomenderos, it became a common policy of the crown in the latter half of the sixteenth century to take over the grants upon the death of encomenderos.

${ }^{20}$ Parry, The Age of Reconnaissance, p. 230.

${ }^{21}$ Kalmanovitz, Economía, p. 17. Kalmanovitz later cites Germán Colmenares' works, La provincia de Tunja and La Provincia de Pamplona (Bogota: Universidad de los Andes, 1969), with the following figures Tunja in 1551 counted some 196,000 Indians but in 1600,75\% of this number had disappeared; in Pamplona, between 1560 and 1640 , the indigenous population had been reduced by $86 \%$. For Popayán and Pasto, the population fell from 31,000 in 1558 to 10,000 in 1608. He also cites Pacheco and Cárdenas figures (from Robert West, La mineria de aluvión en Colombia durante el periodo colonial (Bogota: Universidad Nacional, 1972, p. 75.) for the mining regions for 1540, which counted more than 331,000 indigenous families; forty years later only 29,900 remained.

${ }^{22}$ Kalmanovitz, Economía, p. 17.

${ }^{23}$ Kalmanovitz, Economía, p. 23. 
Replacing this system of labor recruitment in the colonies was a form that became known in New Spain as repartimiento and in Nueva Granada and Peru, as the mita. Influenced by Bartolomé de Las Casas, on Christmas day, 1555 Charles V issued a royal proclamation declaring, "Permitimos que de su voluntad, y pagándoles el justo precio, puedan ir los indios a labrar, y trabajar en las minas de oro, plata y azogue."24 This form of economic organization institutionalized systematic labor recruitment of the Indians by requiring villages to provide a fixed number of individuals to work for local government officials or private employers for a set wage in economic areas of vital interest to the local Spanish economies such as agriculture, mining, and public works. Writes J.H. Parry of the mita in his Age of Reconnaissance, "Employers thus gained a regular but inefficient and constantly changing labour force; Indians were compelled, for several weeks in each year, to do uncongenial work in strange surroundings far from home; and the villagers lost a proportion of the men available for communal farming, so that at home also they had to work harder in order to live...the only way of escape was to accept the implications of a money economy, move to a Spanish settlement, put on Spanish clothes, and become a wage-earner or, if his resources and skill allowed, a craftsman or small capitalist."25 The mita differed from the encomienda system in several ways. First, Indians worked temporarily and irregularly for the government officials and important landowners in the Spanish communities rather than serving as an ongoing labor concession flowing directly from the Crown. Also, laborers did not work for the encomendero, but as has previously been mentioned, for Spanish and creole authorities and private employers in towns and villages. The final important difference between the mita and encomienda in Spanish America was that the Indians received a wage for their work. The wage was not paid directly to the individual, but to the cacique or the capitan, the middle man representative for the contract: ${ }^{26} 20 \%$ went to royal administration, $10 \%$ to the Church, and the rest was usually divided between administrative costs, the local parish, and the Indian village. ${ }^{27}$ In Nueva Granada, the mita lasted until the end of the eighteenth century. ${ }^{28}$

${ }^{24}$ Molina, Las Ideas Socialistas, p. 39.

25Parry, The Age of Reconnaissance, p. 231.

${ }^{26}$ These individual capitanes were usually Indians, but often were not from the same tribe.

${ }^{27}$ Kalmanovitz, Economía. pp. 34-35. Kalmanovitz also argues convincingly that the mita, or as he often refers to this system of labor recruitment, concertaje, contributed to the growth and consolidation of the large cattle ranches or estancias. Since only large landowners, those who possessed 200 or more head of 
It would be an unbalanced exposition of Spanish colonization in the Americas to suggest that economic exploitation was the sole force motivating the colonizers. Representatives of the missionary orders of the Church often sought to protect the Indians from unbridled exploitation by the encomenderos and local officials. ${ }^{29}$ Moreover, as noted by Molina, Charles V regulated the mita in 1549 by setting the working day at eight hours, and prohibiting Sunday work and work during festival days for the Indian laborers. ${ }^{30}$ Molina comments "así, en el atrasado siglo XVI, tenemos normas que sólo cuatro centurias después han llegado a conformar el derecho laboral."31

The diminishing Indian labor force in the Americas led to critical food shortages, and ultimately to the massive importation of slave labor in the seventeenth and eighteenth centuries. In order to expand the economic productive capacity of the colonies in the face of such chronic labor shortages linked to the decline in Indian population, the Spanish began to import negro slaves as early as the late sixteenth century. By the eighteenth century, the labor situation had grown critical enough in the eyes of Charles III to remove all restrictions on the importation of slave labor into the colonies by decreeing free trade in slaves in 1789.32 Although Spanish legislation afforded some protection for America's indigenous people, such legislation as did exist was not applicable to slaves. African slaves were viewed as property, and like their counterparts in the British colonies in North America, they were frequently subject to abuse by their colonial masters.

Throughout her colonial existence, Latin America's local economies were primarily oriented to the production and export of precious metals to Spain. In Spain the influx of gold and silver led to spiralling inflation as imports of manufactures, textiles and even agricultural products from northern Europe accelerated. Rather than develop her own

cattle or owned more than 20 fanegadas had the right to borrow Indian labor through the mita. See his discussion of the mita and encomienda, pp. 22-38

${ }^{28}$ According to Molina, Las Ideas Socialistas, p. 40.

${ }^{29}$ In the Papal Bull of 1537, Indians were determined to be human-beings under Spanish laws. p.43, Molina. For an excellent exposition of the great debates surrounding Spanish colonial views on and treatment of the Indians, including the views of Las Casas and Sepúlveda, see Lewis Hanke's classic, The Spanish Struggle for Justice in the Conquest of America (Boston: Little Brown and Company, 1949).

${ }^{30}$ Molina, Las Ideas Socialistas, pp 38-39. Molina states that this is the first known labor legislation in the Americas.

${ }^{31}$ Molina, Las Ideas Socialistas, p. 39.

${ }^{32}$ Molina, Las Ideas Socialistas, p. 43. 
manufacturing base, Spain's economic system perpetuated the cycle of importing manufactures from abroad and utilizing the economic wealth generated by bullion from the colonies to help pay for these imports. The "seduccíon de metal" in turn caused Spain to run perennial deficits with her trading partners. Improved technology facilitating the extraction of silver from lower grade ore in the mid sixteenth century virtually revolutionized the productivity in the mining sector in America, and helped to encourage Spain's continued reliance on this resource as an important source of revenue for the Royal coffers. ${ }^{33}$ The mines therefore, whether worked by Indian "free labor" or negro slaves, continued to provide the main source of American revenue for the crown up till the time of independence. During the colonial era, Colombia was the major gold-producing region in the New World.

Despite the importance of mining, the region that comprises present-day Colombia also developed a a subsistence agricultural base that permitted it to supply internal market needs. This was a consequence more of the region's mountainous, isolated geographical situation than of any conscientious colonial policy.

\section{SOCIAL THOUGHT AND IDEOLOGY IN THE COLONY AND THE EARLY REPUBLIC}

\section{ECONOMIC FACTORS}

The crown's economic policies in the Americas had important consequences for the social and economic life of the colonies. One critical negative impact of royal policy in the New World on the local economy was the deleterious effect it had on the development of early industry-handicrafts and manufactures. Since the local production of manufactured items was discouraged by the crown in an effort to avoid competition with home industries, the development of rudimentary manufacturing was retarded in Nueva Granada as it was in the rest of Spanish America. Spain viewed the colonies as a primary provider of raw materials to be sold by the mother country in an effort to help maintain the royal treasury and as a market for her limited number of manufactured goods.

Some goods nevertheless, such as the previously mentioned apparel made in the obrajes, were produced by small local craft industries for the local market. Production in colonial Spanish towns was patterned on that of Spain, the guild becoming a central feature

\footnotetext{
${ }^{33}$ In 1543 notes Molina, $65 \%$ of the royal revenues were destined to make payments on the debt.
} 
of economic organization. ${ }^{34}$ Among the most important guilds were the silversmiths, goldbeaters, harness and saddle makers, potters, weavers, hatters, and candle makers, reflecting not only Spain's demand for gold and silver, but local market demands as well. In addition to regulating production, the guilds also served an important social purpose. Often organized into cofradias or cofraternities, each guild had its own patron saint and chaplain to attend to the religious needs of its members. Guild members collected alms for various charities such as hospitals, and often provided volunteers for the defense of the municipality. ${ }^{35}$ In the social services that they provided to their members and their communities, the guild cofradias may be viewed as the non-politicized forerunners of the mid-nineteenth century artisan sociedades democráticas and the later apolitical Mutual Aid Societies.

Haring reports that by the end of eighteenth century, the arts and crafts in the colonies were in decline as a result of lack of adequate preparation and training of their members. ${ }^{36}$ One problem faced by the guilds was the fact that most of the guild ordinances that were established by the municipal cabildos to govern the the guilds in the eighteenth and Nineteenth centuries, dated back to the sixteenth and seventeenth centuries. Many of the ordinances had been imported from Spain with no effort made to adapt them to colonial realities. The outmoded guild structure may have been another factor that contributed to slow economic growth in the colonies. ${ }^{37}$

Another important socio-economic organization in Spanish America was the consulado. Consulados were powerful corporations of merchant importers. With functions similar to a modern chamber of commerce, the merchant guild represented the interests of the European merchant class in the Spanish colonies. While the consulado was comprised of predominantly ethnic Europeans, the craft guilds, for the most part were comprised of mestizo and American-born segments of the population. ${ }^{38}$

${ }^{34}$ Much of the following discussion on the role of guilds in colonial society is based on Haring, pp. 252253.

${ }^{35}$ C.H. Haring, The Spanish Empire, p. 252.

36 As reported by the second Revillagigedo, Haring, The Spanish Empire, p. 253. Although Spanish efforts to discourage the development of local craft industries, and competition from cheap Dutch and English textiles imported through the thriving black market trade may have had as much to do with this alleged decline as a lack of adequate preparation.

${ }^{37}$ Haring, The Spanish Empire, p. 253.

38Haring, The Spanish Empire, p. 254. 
In the Americas, the mercantilist trade with Spain led to the gradual creation of a new class of individuals born in America, the criollos, who would serve as a bridge between the resources and labor of the New World and the markets of the old. The creoles, native-born whites of European descent, reigned over the Indian, the mestizo, and negro slave alike in New Spain, Nueva Granada and Peru. Eventually this new social strata would challenge the Spanish crown for political hegemony in the Americas. Bourbon reforms permitting freer commerce accelerated the process, as criollos initiated new economic ventures such as opening new mines, building sugar cane plantations, and engaging in commerce with the other colonies in the Americas and Europe. As new products began to be traded in ever-greater quantities, commerce continued to increase in importance to the colonies. As more creoles engaged in commerce, the new class expanded: an American bourgeoisie seeking a higher quality of life and posing a challenge to vested economic interests in Iberia was born. ${ }^{39}$

If international commerce initially created a powerful new class in Spanish America, it was property that helped this class consolidate its dominant position in colonial society. In his classic work, The Spanish Empire in America, C.H. Haring succinctly describes the major role of property in the development of an American bourgeoisie:

Of the various moral and material factors that contributed to create and maintain an aristocracy in the Spanish American colonies-differences of race, economic legislation, religion, land tenure-the last was probably the most important, and was the nucleus of most fortunes, land whose value was created by those who did not own it, by Indians and Negroes. Land was the principal source of riches and prestige in a society which disdained trade and industrial pursuits, and the successful miner invested his income in farms and haciendas. Landed property was also an indispensable requisite for the exercise of the few political rights which the colonists enjoyed. A minority of fortunate landowning Creoles lived much like their Spanish ancestors, imbued with similar aristocratic prejudices, and with similar improvidence and lack of foresight. ${ }^{40}$

The American landowners and bourgeoisie would eventually rise to challenge the Spanish monopoly in the Americas. They would import and adopt an ideology that could be readily adapted to circumstances in the colonies: the ideologies of the French Revolution emanating from Europe and of the independence movement in North America found a ready audience in the ascendent landowning and merchant class in Latin America.

\footnotetext{
${ }^{39}$ Molina, Las Ideas Socialistas, p. 61.

${ }^{40}$ Haring, The Spanish Empire, p. 241.
} 


\section{IDEOLOGICAL CURRENTS}

The Enlightenment that had shaken the moral and philosophical foundations of eighteenth century Europe was also imported into Spain's colonial possessions in the New World. The Spanish Inquisition, which was from the outset an important force for maintaining order in Latin America, could not keep eighteenth and nineteenth century philosophical works from reaching the Americas. Even though Enlightenment works were often banned by the Catholic Church and the Spanish Crown, many works of the eighteenth-century political philosophers entered the colonies illicitly, at times brought in by Church officials themselves. ${ }^{41}$ Inevitably, the Enlightenment ideal of reason's superiority over emotion and superstition, coupled with a rather widespread skepticism (among intellectuals, the European bourgeoisie, and a great number of the nobility) about the validity of organized religion as a guiding force in man's day to day actions, would combine to exert a powerful influence over the commercial élite forming in Spanish America, both for those who embraced these new ideas and for those who fought to denounce them.

According to historian Roland Hussey, the generation that led the struggle for independence was strongly influenced by enlightenment thinking. This influence was transmitted to Spanish America via Spain. Hussey writes:

...such Jansenist works in translation as Arnauld's Arte de Pensar (1759) and Jacquier's Instituciones filosoficas (1787) were a main road to knowledge of Descartes...The Portuguese Ameida and the Spanish Feijoo, religiously orthodox but philosophically eclectic, greatly popularized, in their respective lands, the ideas of Bacon, Newton, Bayle, and the Encyclopedists. The Spanish Jesuit Antonio Eximeno was an enthusiast for Locke and Condillac. The Peruvian born Olavide and the Francophile Aranda, both of them Masons, were typical of a host of enlightened men in Spanish office. ${ }^{42}$

Such ideas were often re-interpreted within the familiar Spanish Catholic context of natural law and other elements of traditionalist thought, particularly in conceptualizations of

\footnotetext{
${ }^{41}$ Funk Harries, "Camilo Torres," p. 142.

42Roland D. Hussey, "Traces of French Enlightenment in Colonial Hispanic America," cited in Funk Harries, "Camilo Torres," pp. 152-153.
} 
power and of the ideal society in Latin America. ${ }^{43}$ Colombian sociologist and activist Fals Borda also notes that at the turn of the century, viceroys sent to govern the New Kingdom of Granada brought with them books extolling the virtues of the French Revolution. ${ }^{44}$

Economically, the closing decades of the eighteenth century ushered in an era of colonial prosperity never before witnessed in Spanish America. Principally the result of Bourbon reforms in government taxation, administration, and most importantly, trade policies towards the colonies, this reversed a trend of economic decline particularly pronounced during the latter Hapsburg dynasties. Although illegal trade among the colonies and between the colonies and the rest of the world existed throughout much of the colonial era, as a result of Spain's inability to provide goods to the colonies on a regular basis, after 1700 contraband trade with the English and Dutch became pervasive. Inept management, a cumbersome bureaucracy, the antiquated system of flota $s^{45}$, the strict prohibition of intercolonial trade, the mercantile colonial trade monopoly of Cadiz and Seville, had all combined to create an unworkable system that led to the commercial and industrial stagnation of both the colonies and Spain herself. In the second half of the seventeenth century, direct Spanish trade with her colonial possessions in the Americas progressively declined until between 1706 and 1712 only five frigates sailed to America, and these under protection of French escort vessels. ${ }^{46}$

Gradual Bourbon reforms directed at freer trade generally increased the prosperity of the colonies in the second half of the eighteenth century. By 1789 , legislation had eliminated most restrictions on intercolonial trade. Spain's prohibition of intercolonial trade had been virtually unenforceable because of the difficulties inherent in policing such a huge expanse of Spanish territory as that which ranged from California to Peru. ${ }^{47}$ Nevertheless,

${ }^{43}$ Citing works by several Spanish authors supporting this contention, Harold Davis in his Latin American Thought (New York: The Free Press, 1974) argues that such basic concepts as the different varieties of social contract in currency among the French and British writers had already been established by the Thomist tradition in Spain. Davis also argues that works emanating from colonial Spanish universities, the Laws of the Indies and the liberal Spanish Constitution of 1812 exerted a strong influence over the thought of the educated strata in Latin America. See pp. 37-39.

44 Orlando Fals Borda, Subversion and Social Change in Colombia (New York, London: Columbia University Press, 1969), p. 69.

${ }^{45}$ The Spanish practice of periodically sending large fleets to carry supplies to the colonies in exchange for bullion and other goods.

${ }^{46}$ Haring, The Spanish Empire, p. 314.

${ }^{47}$ Haring, The Spanish Empire, p. 314. 
up until this time, the prohibition prevented those who wished to obey the law from trading with other colonies. Another positive reform in terms of colonial prosperity was the abolition of the Cadiz and Seville trade monopolies with the Indies. By the end of the eighteenth century, the colonies could trade with any seaport in Spain, and major reductions in duties spurred trading activity. By the last quarter of the eighteenth century, Bourbon reforms were coming to fruition. The number of ships calling at Cuban ports alone increased from six in 1760 to 200 in 1778.48 It has been estimated that between 1778 and 1788 the total value of trade with Spain increased along the order of 700 per cent. 49

Growing economic prosperity for the colonies however did not bring universal contentment to the élite in the Americas. Still excluded from the highest government posts and eager to trade freely with the rest of the world, the criollo élite resented the Spaniards who monopolized important government and ecclesiastical posts in the colonies. Criollo interests had little representation in Madrid. Moreover, the municipal cabildos in the Americas, which had once represented an authentic arena of local self-government ${ }^{50}$, had by the dawn of the Nineteenth century lost any legitimate authority they once commanded in the legal and commercial life of the community. 51

Simmering resentment toward the local Spaniards, the example of the United State's War of Independence, and the revolutionary ideology emanating from France created a desire among the criollos to press for greater control of the colonies' economic affairs. The main goal of the criollo elite was equality between themselves and the Spaniards, rather than a social revolution.

In Nueva Granada, Antonio Nariño translated the Declaration of the Rights of Man. The British political thought of Adam Smith, Bentham, and Locke, and later the American works of Thomas Paine, the Federalist papers and the U.S. Constitution influenced the colonial élite. Davis comments that the landowning, class-conscious creoles eventually would weave the natural law theories, the politics, economics, and ethics found in

${ }^{48}$ Haring, The Spanish Enpire, p. 320.

${ }^{49}$ Haring, The Spanish Empire, p. 321.

${ }^{50}$ These included some local powers of taxation, licensing, and initiating and completing public works projects.

${ }^{51}$ Dix, The Politics of Colombia, p. 13. 
Rousseau, Locke, and Montesquieu, into the existing Hispanic tradition. 52 This Hispanic tradition included what Davis has referred to as an "exaggerated consciousness" of being Spanish that was displayed by the élite. He speculates that "this criollo hispanicism was partly the product of a feeling of class superiority traceable to the consciousness of having subjugated the Indian and enslaved the Negro...this class consciousness criollo mentality found such widely differing expressions as sympathy for the Anglo-American planters in their eighteenth century revolt against Europe and acceptance of Pan Hispanism in the 20th century." 53

Napoleon's invasion of Spain in 1808 and the subsequent exile of the king created a vacuum of authority in the colonies. The necessary political conditions were established for the criollos to assert their economic claims. Two years later, on July 20, 1810, Nueva Granada declared its independence. ${ }^{54}$

\section{INDEPENDENCE}

As in the U.S. War of Independence, the "revolutions in America were the work of a comparatively few enlightened, keen-witted leaders, who in many areas represented the ambition of the educated Creole class to supplant the peninsular Spaniards in government and trade, and in whose hands the ignorant classes were a ready tool for the accomplishment of their aims." 55 Unlike the war in North America, those who made the revolutions in Spanish America were not a large, middle class bourgeoisie and small-scale farmer-citizens, but rather were principally made up of gentrified, large-scale landowners.

Early in the war, there was little popular participation. As Molina notes, Bolivar reasoned that the lack of widespread support for the rebellion was the result of hundreds of years of brutality and ignorance as reflected in the masses' submission to crown and church. The sociological reality Molina argues however, was that:

el pueblo no podía menos de ver que quienes lo invitaban a la refriega eran los criollos, los mismos que los habían explotado en las minas y en las haciendas, los mismos que conspiraban contra sus Resguardos y contra su derecho a la tierra. En cambio, del rey recordaban las medidas patemalistas

52Davis, Latin American Thought, pp. 38-39.

${ }^{53}$ Davis, Latin American Thought, p. 11.

${ }^{54}$ Santa Fé de Bogotá proclaimed its independence at this time, but Cartagena did not follow suit until a year later on November 11, 1811.

${ }^{55}$ Haring, The Spanish Empire, p. 324. 
que los habían protegido. Y, luego, estaba la argamasa de la religión para cimentar su obediencia a lo ya conocido. ${ }^{56}$

Bolivar supplied the reasons for the masses to join the cause of the criollos; liberty, the abolition of slavery, and equality. ${ }^{57}$ However, the rhetoric of liberté, egalité, and fraternite, as far as most of the colonial élite was concerned, applied to creole equality to the Spaniard, not equality of the masses to their "natural" superiors. Many in the first decades of the Nineteenth century, as Davis notes in his Latin American Thought, believed that inequality, as dictated by natural law, was the natural state of affairs. ${ }^{58}$ Natural hierarchies existed, their form fixed by the divine legislature. ${ }^{59}$

The victory of Simón Bolívar over Spanish forces in Nueva Granada at the Battle of Boyacá in 1819 marked the decisive defeat of Spain in South America. A social revolution in Latin America however, did not occur. Rather, as many writers have argued, what did take place was a mere "changing of the guard." 60 Colombianist Robert Dix has argued that, "the overall effect of royal authority in the American branches of its empire was to forge a society of exploitative economic and social power in which distinctions of race often reinforced those of social class"61 The social inheritance of the new ruling criollo élite was a highly class-stratified, race-conscious society.

\section{CONCLUSION}

Influenced by his own ideological predisposition, Molina argues that during the colonial era structures were created that only a socialist regime might be able to overcome. Such structures, which he holds, continued to hamper Colombia's development in postindependence times, included the following: "la dependencia externa, la concentración de la tierra, el amor por el monopolio, el desperdicio de los recursos humanos y materiales, la ignorancia, la desigualdad social, el desdén por el trabajador y la distancia entre

${ }^{56}$ Molina, Las Ideas Socialistas, p. 71.

${ }^{57}$ Molina, Las Ideas Socialistas, see pages $72-76$ for a discussion of Bolivar's efforts to enlist the support of the common man.

${ }^{58}$ Davis, Latin American Thought.

${ }^{59}$ Davis, Latin American Thought, p. 14.

${ }^{60} \mathrm{As}$ is apparent from their basic arguments, Davis and Molina share this view along with Robert R. Dix and Kalmanovitz (pp. 90-92).

${ }^{61}$ Dix, The Politics of Colombia, pp. 14-15. 
gobernantes y gobernados. En síntesis, el atraso."62 Although it may be debatable as to whether Molina is on firm ground with his implication about the hypothetical benefits of socialism in Colombia, the essence of his statement is undoubtedly correct. The political, social and economic legacy of colonialism was inherited largely intact by the creole élite that assumed power after the defeat of Spain in the Americas. This feature of Latin American history alone merits the period's inclusion in a discussion of the development of labor in Colombia. The roots of the modern labor movement are not simply planted in twentiethcentury industrialization.

Much has been written about how changes in the system of economic production in Europe, which took place well before the period usually associated with the industrial revolution, impacted the subsequent development of capitalism in the continent. ${ }^{63}$ Building on the work of the earlier dependency theorists, ${ }^{64}$ Immanual Wallerstein has argued that a global economic system, whose roots reach back to fifteenth century European mercantilism, has developed in the modern era. Following a similar line of argument as that advanced by his dependency predecessors, Wallerstein places the nations who have historically provided raw materials to fuel capitalist development, such as Latin America, in a position of economic dependency. It is clear that during the colonial era Colombia served as a colonial provider of bullion to Spain, and was along with other colonies, viewed by the mother country as a dependent market for Spain's limited manufactures. Whether or not the dependency school is relevant to our discussion of the development of a labor

${ }^{62}$ Molina, Las Ideas Socialistas, p. 15.

${ }^{63}$ Franklin Mendels discusses early influences on the formation of an industrial proletariat in his article "Proto-Industrialization: The First Phase of Industrialization," Journal of Economic History, 32:1 (1972), and Immanuel Wallerstein in his The Modern World System I (New York: Academic Press, 1974) as well as his "The World Capitalist System," Comparative Studies in Society and History, Vol. 16., (Sept. 1974), and his later work The Modern World System II: Mercantilism and the Consolidation of the European World Economy, 1600-1750 (New York: Academic Press, 1980) explores the same subject on the macro-level, tracing the development of capitalism to its roots in the fifteenth century.

${ }^{64}$ Basic works on dependency theory include Andre Gunder Frank, "Sociology of Development and Underdevelopment of Sociology," Dependence and Underdevelopment (New York: Monthly Review Press, 1971); Fernando Henrique Cardoso and Enzo Faletto, Dependency and Development in Latin America Translated by Marjory Mattingly Urquidi, (Berkely, Los Angeles, London: University of California Press, 1979). For critiques of dependency theory, see James A.. Caporaso, "Dependency Theory: Continuities and Discontinuities in Development Studies," International Organization, Vol. 34. no 4, (Fall 1980), and David Ray, "The Dependency Model of Latin American Development: Three Basic Fallacies," Journal of Inter-American Studies and World Affairs, Vol. 15, no. 1, (1973). For a general critique of Wallerstein and world system theory, see Peter Worsley, "One World or Three? A Critique of the World System Theory of Irmmanuel Wallerstein" in David Held ed. States and Societies (New York \& London: New York University Press, 1983). 
movement in Colombia, and I suggest that it is, will be discussed at a later stage in the development of the present work. What is immediately relevant to the present discussion is such authors' insistence on the critical importance of utilizing a holistic analysis of social phenomena which incorporates a solid understanding of the phenomenas' historical antecedents. To understand the subsequent development of craft organizations in the nineteenth century and unions in the 20th, the political, economic, and social legacy of colonialism cannot be ignored.

Whether in search of individual riches or the conversion of souls for the Catholic Church, Spaniards drawn to the New World were accompanied by their mental conceptions of community, economic organization, social hierarchy, culture and religion. The Spaniard did not for example, envision himself as a pioneer of a rugged frontier who should have to forge by his own individual manual labor a new life in the isolated wilderness. Visions of work-worn faces and callous-covered hands, of isolated villages of simple pioneer farmers from the British Isles and northern Europe so common in American folklore do not typify the collective Colombian memory of colonists. In contrast to this romanticized vision of their North American counterparts, the Spanish conquistadores in the Americas are often thought of by Colombians as a rather vulgar lot, driven by greed and an appetite for adventure. Like the rugged individualist pioneer of the colonies of North America or the later United States, such a picture is simply a mere caricature. Nevertheless it contains at least a germ of truth: although there were debates about the degree of royal and ecclesiastical protection that should be extended to the Indian, it is clear that the Spaniard had no reservations about exploiting the abundant human resources he came upon in the New World.

Encomenderos, secure in the certainty of their social superiority to peasants in their native Spain, lived like transplanted nobles in the New World, enjoying a readily-available, largely compliant indigenous workforce. The native cultures over which they reigned, even less "civilized" from the conquistadores' perspectives than the Spanish peasantry, were a natural, logical resource to be exploited by their Spanish "superiors." It was not difficult to justify encomienda, the early colonial economic system of forced Indian labor, based on the conquerors' past experience of feudalism. Encomienda in fact, must have seemed to the conquering Spaniards to be a logical, natural method of economic and social organization.

Also, unlike their northern counterparts the Spanish in America took for granted the symbiotic relationship between church and state, whereas many of the colonists in North 
America were fleeing religious persecution in their own lands. ${ }^{65}$ The complementary nature of the church and the state's objectives in the New World lent legitimacy to both undertakings. The church undertook a paternalistic social mission, providing schools, charity operations, asylums, and hospitals for Spanish colonists. It also provided for the spiritual needs of the colonists and undertook the mission of conversion of the continent's native peoples as well as extending them some protection from excessive exploitation by encomenderos and powerful creole and Spanish landowners. The crown also provided some legal protection for the indigenous peoples, although its primary concern was curbing absolute exploitation that would result in the complete decimation of the labor force. The result of the social bonding of church and state was a hierarchical power structure in the colonies characterized by paternalism of the crown and the cross.

With new waves of immigrants in the sixteenth and particularly the seventeenth centuries came major social and economic changes to Nueva Granada. Native Indian groups continued to be decimated by European diseases. With the decline of the encomiendas and the immigration of large numbers of new Spaniards who often settled in or near resguardos, the new migrants frequently took indigenous wives and supported their families by working as tenant farmers (arrendatarios) on the large haciendas, or for those who were more fortunate, on small parcels of land created out of the dissolution of some of the resguardos. Miscegenation between European and native Indian eventually created a majority of mestizos, although white Spanish-descendents comprised a very large minority of the population, and even today continues to be the wealthiest segment of the population. 66

As the native population declined, African slaves were introduced to compensate for the labor shortfall, and began to replace Indian workers in the insalubrious silver and gold mines of Nueva Granada. Slavery dominated mining production on the Pacific coast, in the haciendas of the north coast, and in the southeast. In 1788, approximately $7.2 \%$ of the virreinato's population was comprised of slaves: Kalmanovitz estimates that about 15-20\% of labor at the same time was in the mining sector. ${ }^{67}$ Today, descendents of African slaves constitute another important element of Colombia's ethnic make up.

${ }^{65}$ I am not intimating that in the early colonial period in the British colonies that religious tolerance was any more commonplace than in the Spanish colonies, but simply that the primary motivations of colonists in North and South America were quite different.

${ }^{66}$ Approximately $20 \%$ of modern-day Colombia's population is classified as white.

${ }^{67}$ Kalmanovitz, Economía, p. 87. 
Spanish immigrants also brought with them organizations imported from the Old World, including the consulados which became the domain of the well-to-do mercantile élite, and the guilds of the primarily mestizo, skilled crafts sector. The early artisan worker organizations, the guilds, were imported from Europe. Social divisions separating guild from consulado, artisan from merchant were not post-independence phenomena, but rather trace their roots back to colonial times. Artisans were the major force behind urban labor organization in nineteenth and early twentieth century Colombia; the guilds of colonial times were the social and economic organizational forerunners of the sociedades democraticas of the nineteenth century.

Artisan industry began to develop in various regions of the country, most notably in Santander and Antioquia. Boosted by demand from smallholders, tenant farmers and the large haciendas, a thriving cottage industry developed to supply simple cotton manufactures to the local market. Although in the countryside such artisans were usually only part-timers since most were campesinos engaged primarily in agriculture, the products of the familybased cottage industry were not only consumed by the campesino and his family, but rather had a much broader market. ${ }^{6}$

In Bogotá, the largest single segment of the population was comprised of independent artisans. Though most owned their means of production and could therefore be considered as independent craftsmen, there was a strong social wedge that separated them from their landowning 'superiors'. In fact, even though large numbers of artisans had fought for the creole cause during the war for independence, most were denied the right to vote in the new republic as the result of income, property ownership and literacy restrictions. Thus although urban artisans were not completely dependent on or subservient to wealthy landowners as were tenant farmers, they were clearly viewed as social inferiors by the Bogotá élite. Moreover, as will be discussed in the next chapter, despite their numbers, as a political force organized to promote and defend their economic interests, the artisans had to forge a partisan alliance with the élite of the established political parties: Liberal and Conservative. The majority of artisan sociedadedes democraticas' decisions to ally themselves with the Liberals ultimately proved to be counterproductive when artisan activism became a threat to the established interests of the élite of both the Conservative and Liberal Parties. Artisan dependence on the élite-led Liberal Party in the mid-nineteenth century never resulted in the long-sought for tariff relief that the artisans hoped would preserve their economic existence.

${ }^{68}$ Kalmanovitz discusses these artisan organizations in Economía, pp. 64-65. 
The pattern of property ownership and the system of labor recruitment were also important features that helped not only to define social relations in colonial times, but which continued to play a central role in the development of social and economic relations in the Republic after independence. Under the encomienda system, encomenderos had controlled large tracks of land and had been awarded "grants" of Indian labor by the crown. Later, the mita or concertaje, essentially forced Indian labor which paid a wage to the village or labor contractor, contributed to the consolidation of the large estancias. Large landowners were able to greatly expand the amount of productive lands under cultivation with the use of cheap Indian labor, though at the expense of diminishing the agricultural production available to meet the indigenous market needs of the resguardo. ${ }^{69}$

Liberal ideas, imported from Europe and the United States, provided creole ideological justification for their quest for greater autonomy in economic affairs and eventually, emancipation from Spain. Rising economic prosperity in the colonies and Napoleon's fortuitous victory over Spanish royalist forces and subsequent occupation of Spain set the stage for rebellion in America. Initially, the rebellion was largely an élite affair between Spaniard and Spanish descendent. Eventually however, the rebellion rallied enough support from popular quarters with its ideological thetoric of liberty and equality to dislodge permanently the Spanish from South and Central America.

The great victory of the creoles in Nueva Granada did not bring equality to the mestizo, nor did it bring liberty to the Negro slave or eliminate the exploitation of the Indian. ${ }^{70}$ In fact, haciendas would experience their greatest expansion in history in the mid-nineteenth century as large amounts of Indian resguardo land were freed and large landowners enclosed more and more territory. Indians, mestizos in the countryside, and poor whites alike worked for the hacendados, the majority as sharecroppers and tenant farmers. Toiling under even more marked social distinctions than the inferior social position held by the artisan vis à vis the bourgeois élite in the towns of Nueva Granada, labor in the countryside assumed an almost completely subservient role that helped maintain their dependence on the wealthy landowning class.

${ }^{69}$ See Kalmanovitz, Economia, pp. 33-38.

${ }^{70}$ Slavery was not abolished until 1851 , only a dozen short years before it was ended in the United States. 


\section{CHAPTER 3}

\section{NINETEENTH CENTURY COLOMBIA}

Colonel Aureliano Buendia...sat in a chair between his political advisors and, wrapped in his woolen blanket, he listened in silence to the brief proposals of the emissaries. They asked first that he renounce the revision of property titles in order to get back the support of the Liberal landowners. They asked, secondly, that he renounce the fight against clerical influence in order to obtain the support of the Catholic masses. They asked, finally, that he renounce the aim of equal rights for natural and illegitimate children in order to preserve the integrity of the home. "That means, "Colonel Aureliano Buendia said when the reading was over "that all we're fighting for is power."

"They're tactical changes," one of the delegates replied. "Right now the main thing is to broaden the popular base of the war. Then we'll have another look."

One of Colonel Aureliano Buendia's political advisors hastened to intervene. "It's a contradiction," he said. "If these changes are good, it means that the Conservative regime is good. If we succeed in broadening the popular base of the war with them, as you people say, it means that the regime has a broad popular base. It means, in short, that for almost twenty years we've been fighting against the sentiments of the nation."

Gabriel Garcia Márquez, One Hundred Years of Solitude ${ }^{1}$

\section{THE EARLY REPUBLIC}

Despite the tremendous destruction suffered by Nueva Granada's economy as a result of damage to trade and property inflicted during the war for independence, a remarkable pattern of continuity from the late colonial era can be witnessed during the early post-independence period: historians in fact have dubbed this period the Neo-Bourban era.

The latifundio and landed property were preserved, along with the Spanish tariff system, monopolies, including the tobacco monopoly (estancos), the diezmos, as well as the central role of the Catholic Church in social and civic affairs. As has been argued in Chapter One, the war for independence was not as much a social revolution of all segments of Colombian society against a corrupt and burdensome Crown as it was a movement of the indigenous élite rebelling against Spanish hegemony in commercial, political, and ecclesiastical affairs. Moreover, as Robert Dix has argued that unlike in the United States war of independence, the wars to the south destroyed the "only legitimate authority and the only source of 'rights' there had been...the wars of independence in South America, instead of preserving legitimate institutions from outside, arbitrary interference, as they

1 Gabriel Garcia Marquez, One Hundred Years of Solitude (New York: Avon Books, 1970), p. 162. 
largely did in the north, destroyed the fabric of authority." 2 Of course Nueva Granada was not unique in this respect, as the wars for independence yielded similar outcomes in Mexico, Central America and other South American republics. The leaders of the new states were nearly always wealthy or influential landowners and merchants who also came to occupy the highest positions in the clergy, the army, and the government bureaucracies. ${ }^{3}$

Although numerous political, social, and economic ideologies competed for hegemony over the minds of the Colombian ruling classes, two principal antagonistic systems of thought would clearly emerge by the middle of the nineteenth century: conservatism and liberalism. The incessant struggle between conservative and liberal ideas would ignite dozens of armed clashes (including several major civil wars) between the proponents of each of the opposing camps and would establish a two-party political system that with very few minor exceptions, would dominate Colombian politics until the present day. ${ }^{4}$

Both ideologies' intellectual roots lie in Europe, and were transmitted to the Colombian intelligentsia within months, sometimes weeks, of their original publication. From both Europe and the United States, liberal and utilitarian ideas were imported into Latin America, while Comptian positivism and German idealism, especially Hegel, were widely read. 5 Davis argues that these trends led to the development of the distinct

${ }^{2}$ Dix, The Politics of Colombia, p. 16.

${ }^{3}$ Molina, Las Ideas Socialistas, p. 15. See also Bazant, A Concise History of Mexico: from Hidalgo to Cárdenas 1805-1940 (Cambridge, England: Cambridge University Press, 1979) and Roger Hanson's, The Politics of Mexican Development (Baltimore: Johns Hopkins University Press, 1982), for an account of Mexico and Woodward, Ralph L. Central America: A Nation Divided (New York: Oxford University Press, 1976) for Central America.

${ }^{4}$ The only major exceptions were the short periods heralding transitions from Conservative to Liberal or Liberal to Conservative rule such as the National Party of Rafael Nuñez in 1885 (coalition of Independents-Nuñista Liberals and Conservatives), and the Republican Party (Coalition of Conservatives and Liberals emerging from the destructive Thousand Days War at the turn of the century). Both of these were transitional coalition governments comprised of moderate liberals and Conservatives. In presidential elections, party factionalism in 1945-46 in the Liberal Party allowed a Conservative victory and the one of 1934 that presaged a Conservative defeat. Presently however, the political climate in Colombia is more complicated. A more serious challenge to two-party hegemony may be forming in the 1990's. The official Conservative candidate came in fourth in the polling, outdistanced by a socialist contender from the recently legalized M-19 Party, Antonio Navarro Wolf who finished third. This is perhaps the culmination of a trend in Colombia caused by rapid urbanization, that has in turn led the Conservatives to slowly but steadily lose electoral strength throughout the twentieth century as the party's traditional base of tural support has eroded.

${ }^{5}$ Funk Harries, "Camilo Torres," p. 174, Davis, Latin American Thought, p. 6. 
liberalism of France, Spain, Portugal and Latin America. ${ }^{6}$ Liberalism had perhaps its greatest influence on the political economy, which was built around British laissez-faire and French physiocratic doctrines. Early versions of positivism held that the laws favoring human progress could only be determined through the application of the scientific method. Santander himself had a particular affinity for British political and economic thought, especially Bentham's doctrine of utilitarianism. The areligious aspect of liberal philosophical and political thought often provoked strong reactions from traditionalist sectors in Nueva Granada. Molina writes that, "Los medios católicosse alborotaron, porque sostenían que el utilitarismo del sabio inglés, quien más tarde fue amigo pesonal de Santander, chocaba frontalmente con la religión católica. Esos medios señalaban con alarma el ateísmo de Bentham, cuyo sistema, según la síntesis hecha por Azuero, reposa en el único y exclusivo principio de la utilidad general, de la utilidad bien entendida, es decir el Bien es el mismo placer o la causa del placer; y el Mal el dolor, o la causa del dolor."7

Catholic traditionalist thought, which had stood in opposition to the ideas of the enlightenment a century earlier, was to be the intellectual forerunner of nineteenth century conservatism. Paradoxically, argues Davis, this conservative strain "also gave rise to the Christian traditionalism of France and Spain, a form of romantic idealism that produced distinct, yet similar expressions in Latin America. ${ }^{8}$ Why would a society such as Colombia, one that many writers have considered deeply religious and socially conservative, exhibit a readiness to accept such radical ideas as those emanating from the enlightenment, the radical ideals of the French Revolution and Bentham's secular utilitarian ethic, ideas which challenged the fundamental basis of a hierarchically organized, paternalistic state that received its legitimacy from God and received the blessing of the Holy Roman Church? Part of the answer surely lies with the reality that of course, such radical ideas were never universally accepted by the Colombian élite. Moreover, the ideas form the basis of that corpus of thought loosely termed "liberalism" that came to distinguish its supporters from their traditionalist, later "conservative" opponents. Those who adopted the credo of liberalism did so for several reasons, (including ideology), which will be explored more fully below.

\footnotetext{
${ }^{6}$ Davis, Latin American Thought, p. 7.

${ }^{7}$ Molina, Las Ideas Socialistas. p. 92.

${ }^{8}$ Molina, Las Ideas Socialistas, p. 7.
} 
Recall the initial reluctance of the masses in Nueva Granada when urged to raise arms against their legitimate King, who had over the years alongside the Church been the sole protector of many of their rights against abuses by the local élite. Moreover, the king received divine authority to govern not from the people, but from God himself. An appreciable number of the Creole élite had also remained loyal to the Spanish Crown. Even before the pendulum had militarily swung decidedly in Bolivar's favor after the Battle of Boyacá however, a strong anti-Spanish movement had gained powerful momentum.

In Europe, Spain had long been viewed as backward and superstitious: its economic affairs mismanaged through antiquated methods were further exacerbated by layers of superfluous bureaucracy. Several factors contributed to the spread of such a negative perception of the mother country in Latin America. The first of these is the fact that the criollos witnessed first-hand the general administrative and economic mismanagement of the colonies' affairs over the prior 150 years of colonial rule. Despite the fact that colonial administration had improved dramatically during the Bourbon era, the Creole élite sorely felt its exclusion from high posts in both government and Church. Moreover, the economic success of Spain's free-trading rivals was readily apparent as Dutch, English and French merchantmen conducted a thriving and extremely lucrative contraband trade with the Spanish colonies.

After independence had been obtained, there was a powerful movement to reject the "retrograde" Spanish heritage because, "it was not thought to be a past out of which the future could grow, but rather an obstacle to that future." 9 In its place, many attempted to construct a "modern" Colombian outlook based on foreign models imported from England, North America and France.

During the independence struggles, no political parties developed espousing a coherent set of tenants or programmatic reforms. Molina comments, "La época no era para partidos orgánicos, sino para facciones, grupos versátiles, sin ideología precisa, aptos sólo para bregar ásperamente por el mando como fuente de privilegios...Por ausencia de formaciones políticas permanentes, los caudillos en plaza, con la mira puesta en el impulso a los egoísmos locales, disfrazados de nacionalismo, tenían que volverle la espalda a las grandiosas concepciones intergracionistas." 10 The following section will look at the

\footnotetext{
${ }^{9}$ Davis, Latin American Thought, p. 4. See also Molina, Las Ideas Socialistas, pp 60-64. ${ }^{10}$ Molina, Las Ideas Socialistas, p. 93.
} 
various principal issues and outlooks that developed to separate the early Conservative and Liberal Parties.

\section{CONFLICT AND IDEOLOGY: BIRTH OF THE TWO-PARTY TRADITION CONSERVATIVES AND LIBERALS}

By the mid-nineteenth century, the Conservative and Liberal Parties had become firmly established fixtures on the Colombian political scene. In 1838, Catholic priests had organized a "Sociedad Catolica" in large measure to counteract the further spread of the ideas of the philosophes. After the civil war of 1839-41, several liberal reforms that had been undertaken by Santandér and which included reductions in import and export duties, limitations on the Church's acquisition of property through mortmain, and reforms aimed at limiting the role of the Church in education, were all reversed under the strong "conservative" reaction writ into law in the form of the Constitution of 1843.11 The new constitution created a strong central government with a powerful executive, and restored the Church to its formal privileged position in society. Quickly banned by the government were works by Jeremy Bentham as the new regime sought to stem the tide of liberal ideology. 12

During the administration of Tomás Cipriano de Mósquera, considered by scholars today as a moderate conservative, many infrastructural reforms were taken to bolster the Colombian economy. Steam navigation introduced on the Magdalena considerably improved river transportation, mule trails (the primary means of transportation in Colombia's mountainous interior) were greatly expanded, tariffs were reduced by $25 \%$, construction on the inter-oceanic railway was begun in Panama, postal service was improved, a military academy was established, one of its purposes being to train engineers, and much of the public debt was retired. ${ }^{13}$ Henao and Arrubla, date the formal creation of the two dominant Colombian political parties from this time: "The party in power [Mósquera's administration] having assumed the name 'conservative,' the opposition called themselves 'liberals.' This party included the liberals of the revolution of 1840 , the radicals represented by the young men educated in the cloisters and universities-men who desired innovations, drank in the doctrines of Bentham, and opposed conservatism because

\footnotetext{
${ }^{11}$ Bergquist, Coffee, p. 15.

${ }^{12}$ Bergquist, Coffee, p. 15.

${ }^{13}$ Bergquist Coffee, p. 11, Henao and Arrubla, History of Colombia, pp 450-451.
} 
it suggested quietism and reaction." 141849 heralded a new era with the presidential election of José Hilario López in which Liberals would dominate national politics for more than thirty years.

What were the material and ideal interests that separated Conservatives form Liberals? As we have already mentioned, even as early as the independence movement one could see the outline of two general tendencies among the élite: one was broadly "conservative", the other "liberal." The first outlook was more traditionalist, taking its political and social aspirations from Hispanic traditions and its philosophical from the Scholastic tradition of Catholic Spain. In the early nineteenth century, such an outlook consisted of a hierarchical vision of society that was set in stone (each individual must assume the station in life ordained to him by God); belief in a highly centralized, strongly paternal state; the conception of the Catholic Church as an integral, active component of both Colombian social and political life, and finally; a rejection of the secularizing impact of the Enlightenment, the French Revolution, utilitarianism and positivism.

Liberals on the other hand received their ideological inspiration from the rapidly industrializing nations - England, France and the United States. In these nations, many Liberals travelled, studied, and witnessed first-hand the massive accumulation of capital, the success of laissez-faire economic policies, and here also they absorbed the social political and economic philosophies in currency among their Liberal European and American counterparts. ${ }^{15}$ Referring to specific items on the Liberal reform agenda, an editorialist writing to the Gaceta Oficial in 1851 is informative:

What does Nueva Granada hope to achieve in 1851 ? The answer is reform of the constitution, abolition of slavery and the death penalty, free enterprise in the economic field, organization of national guards in order to achieve the suppression of the permanent army, the emancipation of the Church,

${ }^{14}$ Henao and Arrubla, History of Colombia, p. 453.

${ }^{15}$ On nineteenth century Colombian Liberalism, see Molina's historical trilogy, Las Ideas Liberales en Colombia, 1849-1914 (Bogotá, Colombia: Ediciones Tercer Mundo, 1979); Las Ideas Liberales en Colombia, 1915-1934 (Bogotá, Colombia: Ediciones Tercer Mundo, 1982); Las Ideas Liberales en Colombia, de 1934 a la Iniciación del Frente Nacional (Bogotá, Colombia: Ediciones Tercer Mundo, 1986). Good sources on the development of Conservative ideology include James Park, Rafael Núnez and the Politics of Colombian Regionalism 1863-1886 (Baton Rouge and London: Louisiana State University Press, 1985) and Frank Safford, The Ideal of the Practical: Colombia's Struggle to Form a Technical Elite (Austin and London: University of Texas Press, 1976), in addition to the works cited above. 
popular election of bishops and priests, and adoption of a direct national tax until the abolition of all custom duties is achieved. ${ }^{16}$

The Liberals also favored the breakup of the Indian resguardos, expulsion of the Jesuits from Colombia, extreme federalism, and educational reform. ${ }^{17}$ Liberals also sought, and obtained the official separation of Church and state, the first time this had occurred in all of Latin America.

The actual political and economic reforms achieved by a nearly unbroken succession of Liberal governments between 1849 and 1885 were remarkably consistent with the Liberals' professed political beliefs as well as their economic interests. The reforms had the effect of transforming Colombia's political economy from its colonial, neoBourbon beginnings to a laissez-faire, export-oriented trading nation. This feat was accomplished by liberating tobacco production through elimination of the state monopoly; a dramatic reduction of the alcabala and other estancos, and economic policies designed generally to stimulate the development of export agriculture and international trade while de-emphasizing the stimulation of local industry considered to be simply uncompetitive. Florentino González, one of the first and foremost exponents of free-trade in Nueva Granada wrote in 1846 before the Liberals officially came to power, "La Nueva Granada no cuenta con facilidades para montar fábricas, ni con productos para alimentarlas, ni con consumidores que prefieresen sus manufacturas en concurrencia con las extranjeras." 18

A year later, Treasury Minister González reported to Congress that "Europe...fulfills its mission in the industrial world by giving various forms to raw materials. We too should fulfill our mission, and there is no doubt as to what it is, if we consider the profusion of natural resources with which Providence has endowed this land. We should offer Europe raw materials and open our doors to her manufactures, to facilitate trade and the profit it brings, and to provide the consumer, at a reasonable price, with the products of the manufacturing industry." 19 In addition to advocating radical laissez-faire economic policies, the Liberals sought to stimulate agricultural export production by freeing

${ }^{16}$ Gaceta Oficial, Year XX, no. 1184 (January 2, 1851)., quoted in Urrutia, pp. 27-28.

${ }^{17}$ Molina, Las Ideas Socialistas, p. 100-102.

${ }^{18}$ Molina, Las Ideas Socialistas, p. 98. González had become secretary of the Hacienda in 1846.

${ }^{19}$ Miguel. Urrutia, The Development of the Colombian Labor Movement (New Haven, London: Yale University Press, 1969) p. 7. 
up unproductive Church lands which comprised perhaps one-third of the arable land in Colombia, ${ }^{20}$ by expulsion of the Jesuits and massive confiscation of ecclesiastical property, and by dismantling the Indian resguardos thereby adding to the market economy substantial landholding that had heretofore been utilized for communal subsistence agriculture by the Indians or lain unproductive in the hands of clerics. ${ }^{21}$

Nueva Granada's reform-minded Liberals were also influenced, as was usually the case for Latin American intellectuals, by events in Europe, particularly the upheavals of 1848. Utopian socialists ideals of Louis Blanc and other socialist writers and the revolutionary poetry of Lamartine further increased the gulf separating Colombian Liberals from Conservatives, who were more strongly imbued with traditional Hispanic and religious values. ${ }^{22}$

Despite these significant ideological differences however, it is important to recognize that both Conservatives and Liberals shared important élite material interests, in addition to their class-based prejudices. Although the Liberal's ideology was couched in the language of liberiy and equality, Liberals fundamentally shared a hierarchical view of society in which an enlightened élite directed a "democratic" republic from above. ${ }^{23}$ According to Arrubla and Henao, during the early stages of party formation, "The young men of both parties employed the vocabulary of the French Revolution, and the words liberty, equality, fraternity, democracy, popular sovereignty, and universal suffrage were much in vogue among our popular societies, whose orators used them along with the Bible and the name of Jesus Christ; but the conservatives repudiated socialistic and communistic ideas." 24

${ }^{20}$ Urrutia, Development, p. 4.

${ }^{21}$ The profound impact Liberal reforms wrought on the structure of the Colombian economy and more particularly, their influence on urban, artisan production will be discussed in greater detail below. Also, the Liberal's rationale and justification for the most important pieces of Liberal legislation and the actual social ramifications of these significant mid-century Liberal reforms wiil be discussed.

${ }^{22}$ Molina, Las Ideas Socialistas, p. 7.

${ }^{23}$ The mainstream of both parties believed in the sanctity of private property and therefore had a vested interest in maintaining this inviolable right. Elites of both parties generally sent their sons to the same educational institutions, dressed in the same manner, spoke with the same accents, enjoyed imported luxuries reserved for the pocketbooks of the rich and, despite disagreement on the degree of the Catholic Church's role in politics and society, attended the same churches.

${ }^{24}$ Arrubla and Henao, History of Colombia, p. 458. The impact of utopian socialist ideas were not limited to Liberal circles however. Small rumbers of radical Catholic clergymen, artisans, and even some Conservatives at times sought to use socialist arguments to support their policies or positions. The 
Although some writers have claimed that the Conservatives were not closely involved with the export economy but rather were often identified with agricultural production destined for domestic consumption, ${ }^{25}$ Park points out that this evidence is far from conclusive. 26 Several authors have also pointed out that both large landholders and wealthy merchants benefitted from free trade policies by paying lower prices for imported textiles and luxury items, and that free trade policies were actually originally initiated under the impetus of Florentino González, Conservative Secretary of the Treasury under Mósquera's first administration. ${ }^{27}$ Moreover, it appears that large landholders did not uniformly support the Conservative Party, as may generally be the case elsewhere in Latin America. Though data is scarce for the period, it is clear that landholders supported both parties. ${ }^{28}$ Moreover, the expansion of the haciendas and Latifundia, often considered an economically regressive phenomena by late nineteenth century Liberals, date from the era of mid-century Liberal reforms. ${ }^{29}$

One striking similarity between the Liberal and Conservative parties has been their class composition, which has remained fairly consistent up through the late twentieth century. Despite rather clearly defined ideological borders, ${ }^{30}$ both parties are noted for

most significant impact of socialist ideas outside their obvious influence on the Liberal intellectual Gólgotas was the influence of Louis Blanc on some of the members of the artisan sociedades democraticas. Molina's Las Ideas Socialistas en Colombia discusses in some detail how utopian socialism influenced these groups in the nineteenth century. Socialism's influence on the intellectual development of the Gólgotas and the Sociedades is explored in greater detail later in the present study.

25Dix, The Politics of Colombia, p. 18, Bergquist, Coffee, pp.7-9; 14-15, Molina, Las Ideas Socialistas, pp. 97-101 and Urrutia, Development, p. 50.

${ }^{26}$ Although Park, Rafael Nañez (p. 269) argues that Bergquist is incorrect in his assumption that the rise and dominance of the Liberal Party closely parallels the success and decline of the export economy, (Park argues instead that the clear preference for centralism and church-state cooperation were the real forces behind Liberalism's decline) he ignores the fact that the Liberals were extremely consistent in their advocacy of laissez-faire trade policy. It is improbable that liberal ideology alone could maintain such consistency of policy for a half-century without clear material interests reflecting this fact. Most Liberal leaders of the era, such as Miguel Samper, were sons of merchant families, families engaged in export agriculture or families tied in some way to the export economy.

${ }^{27}$ Both González and Mosquera himself however may be viewed historically as socially and politically conservative while economically liberal..

${ }^{28}$ Park, Rafael Núñez, p. 269.

${ }^{29}$ Urrutia, Development, pp. 27-28; Molina, Las Ideas Socialistas, pp.100-102.

${ }^{30}$ Albeit they were ideologies that underwent tremendous evolution in the second half of the nineteenth and first half of the twentieth centuries. At century's end, both parties generally agreed on their support of free-trade, but still disagreed on issues such as the Church's involvement in the social life of the nation and federalism. In the twentieth century, there is also a marked move by the Liberal Party away from 
their multi-class, national composition. ${ }^{31}$ Despite their obvious ideological differences,.such similarities as those mentioned above have enabled élites of both parties to forge alliances when a threat has arisen from below to challenge their privileged position in society.

Distinct elements of each party's ideological positions appealed to urban and rural labor. Although initially literacy and property restrictions limited the political participation of large segments of Colombia's rural labor force, many of the city-dwelling artisans actively participated in Colombian partisan political struggles from the earliest days of the Republic. Each party was created and led not by middle class elements in Colombian society, but by an élite"oligarchy" that forged party strength from patron-client relationships. In his essay on the historical antecedents to the National Front, Harvey F. Kline describes the early development of party loyalties:

[Liberal or Conservative Party'] support was probably not because of socioeconomic programs, but through the use of the patron-client relationships. At the beginning of party history, the voters for the parties were the clientele of the élites. Dependent campesinos voted for the party of the landowner, whatever it was. The clientele of economic élites other than the large landowners went along because of similar dependency...In Colombia, however, many families had martyrs who had died for a party in one of the frequent civil wars. As a result, the masses developed intense loyalties, which reinforced the initial patrimonial reason for choosing a political party and in some sectors outlived it. Over time, the masses became the cannon fodder for the party élites in the wars between the two parties... The appearance of a strict and intense political socialization which transcended patron-client relationships among the Colombian lower classes

classical laissez-faire liberalism and towards modern (welfare) liberalism in which the state plays a more interventionist role in economic and social affairs.

${ }^{31}$ Although Mauricio Solaún in his essay "Colombian Politics: Historical Character and Problems," in Albert R. Berry, Ronald G. Hellman and Mauricio Solaún, Politics of Compromise: Coalition Government in Colombia (New Brunswick, New Jersey: Transaction, Inc., 1980) has argued that the parties have been ideologically heterogeneous and that party identification "has tended to be inherited rather than the product of thoughtful or ideological decision", the idea that the parties were ideologically heterogeneous can probably only be generalized to the period immediately following the Thousand Days War, and the modem period beginning with the National Front. The thesis of the "hereditary hatreds" is also probably applicable to peasants in the nineteenth and the first half of the twentieth century, with certain exceptions outlined in the course of this paper. The radical measures taken by the Liberals in the mid-nineteenth century and Alfonso Lopéz's "Revolución en Marcha" serve as corrective examples to illustrate the importance of ideology among dynamic intellectual reformers. Liberal anticlericalism in both centuries is not simply a contributing factor to the "ingrained partisan hostility" but is rather an important ideological dimension of the conflict between Liberals and Conservatives. The "Manichean element" of the conflict as described by Solaún (p.5) is often related to ideological justification of actions and positions by competing interests. He is thus ccrrect in asserting that this Manichean fervor was itself a source of partisanship. 
seems to be a product of having relatives who had been killed by the other party. ${ }^{32}$

Even today party loyalties extend to all strata of society, and one can find Liberaldominated peasant communities as well as Conservative working-class neighborhoods. Moreover, there is empirical evidence that indicates the the masses' sense of party identification is intensely strong, probably more powerful than that of the élite party leadership. ${ }^{33}$ At mid-century when the parties were taking shape, both parties actively recruited political support from the masses. Since the peasants had long relied on their rural patrons, such political ties seemed inevitable. In urban areas, such ties also developed, especially through the Liberal-oriented artisan sociedades democráticas and mirrored in their Conservative, Church-influenced counterparts. Party identification became essential for both rural and urban workers as a means to advance their individual interests in a variety of areas including, obtaining employment, economic favors, favorable court decisions, etc.. "Even at the level of veredas, the subdivisions of Colombian municipios (counties)," writes Charles Bergquist in his study of labor and coffee, "smallholders or sharecroppers of one political affiliation might enlist the support of local urban politicians and lawyers in their resistance to large landowners-or to other smallholders-of opposite political loyalties." 34

Although not really mass-parties in the common understanding of the term, ${ }^{35}$ the parties have always had national, regional and local directorates as well as youth organizations and political clubs (such as the mid-nineteenth century Republican School). On a regional level, each party had traditional strongholds of support. The Liberals, who have been traditionally somewhat stronger in urban areas, also have garnered strong support from Cundinamarca, Santandér, and Boyacá while Conservatives have been strongest in Antioquia and Tolima. In each of these cases however, it is important to remember that there was a relatively large, and generally active opposition party comprised of a sizeable segment of the population in each of the states.

${ }^{32}$ Harvey F. Kline, "The National Front: Historical Perspective and Overview," in Berry, Albert R. , Ronald G. Hellman and Mauricio Solaún, Politics of Compromise: Coalition Government in Colombia (New Brunswick, New Jersey: Transaction, Inc, 1980), p. 61.

${ }^{33}$ Kline, "The National Front," p. 62.

${ }^{34}$ Bergquist, Labor, p. 291.

${ }^{35}$ Kline, "The National Front," p. 60. 
Regionalism, which has always been a critical ingredient in Colombian politics, has been important not only in the broad context of political partisanship, but has also served as a major theme of Liberal reformers who believed that a weak federalist system was the best guarantor of individual liberty and regional autonomy. Probably the major factor contributing to the strong regionalist sentiment one finds in Colombia, is the nation's special geography. It has played a critical role in the development of regional social and cultural variations and loyalties that persist to the present day. Before considering the impact of federalism on Colombia's political development in the nineteenth century, we will briefly look at the nation's unique geography.

\section{REGIONALISM AND THE GEOGRAPHY OF COLOMBIA}

As every history of Colombia has noted, the geography of the nation has exerted a powerful influence on the nation's social, economic and political development. The towering flowing peaks of the Andes mountains has encouraged regionalism, often cited as a powerful variable in the partisan political battles between Liberals and Conservatives. The temperate zone of valleys and plateaus is divided by the central chain, the three Andean chains that run north-southwest and comprised of the Cordillera Central (Central Chain), the Cordillera Oriental (Eastern Chain) and the Cordillera Occidental (Western Chain). In Colombia, one finds all climates ranging from the sparsely populated, steamy jungles of las Amazonas to the tundra region, the páramos and the areas of permanent snows above 15,000 feet. It is in the temperate valleys of the Colombian highlands, particularly the Cordillera Central and the Cordillera Oriental where one finds Colombia's leading urban centers, including the nation's capital, Bogota. With a year-round cool climate, Bogotá is situated in tierra fría. The populous, mountainous interior remains difficult to access by ground even today, and was in the nineteenth century nearly impossible to reach overland form the coast and difficult to reach even via Colombia's fluvial arteries.

Colombia's second leading city famed for its high level of economic development is Medellín, found in tierra templada, temperate country in the department of Antioquia. Medellín, currently about half as large as the capital city, was a powerful Conservative stronghold throughout the nineteenth and most of the twentieth century. It is currently the heart of Colombia's thriving textile industry and is the nation's leading manufacturing center. In the Southwest between the Cordillera Central and the Cordillera Occidental lie the important cities Cali, nearly as large as Medellín, and Popayán, today a small city, but an important commercial and administrative center on the trade route to Quito in the eighteenth and nineteenth centuries. 
The fact that Colombia has several important regional urban centers distinguishes it from the typical pattern of urbanization found in other Latin American nations. Geographer Alen Gilbert highlights this fact when he writes, "Of all the countries in the continent..., only Colombia demonstrates the 'rank-size' hierarchy which many writers deem to be desirable. In that case Bogotá is approximately twice as large as Medellín [today nearly three times as large ${ }^{36}$, three times the size of Cali and has four times the population of Barranquilla." 37 This regionalist aspect does not stop at Colombia's four leading cities. The Caribbean port cities of Cartagena and Santa Marta, the important departmental capitals Bucaramanga, Manizales, Cúcuta, Pereira, Ibagué, and Pasto all have more than 250,000 population and have become important commercial centers on Colombia's geographical map.

This regional distribution of population has had two important consequences for the development of the Colombian polity: regionally-based party organizations led by caudillos and at the local level, gamonales (local party bosses) linked loosely to party headquarters in Bogotá; and, regional economic and cultural centers distinct in many ways form other regional centers. ${ }^{38}$ Strong regionalism, resulting primarily from the difficulties of access and the lack of communications linkages between difficult mountainous terrain, has been reinforced by racial heterogeneity, climactic variances, and differing natural endowments of physical resources. By mid-nineteenth century for example, Indian influences remained strong only in the eastern highland and the mountains of southern Cauca, while the majority of the population, comprised of mestizos, was scattered throughout the country. ${ }^{39}$

36In 1989, Medellín counted nearly 1.6 million inhabitants, Cali, 1.5 million and Bogota nearly 4.5 million. Atlas y geografia de Colombia (Circulo de Lectores, 1989).

${ }^{37}$ John W. Sloan, "Regionalism, Political Parties, and Public Policy in Colombia," Inter-American Economic Affairs, 33:3, (1979), p. 39.

38 James William Park in his Rafael Nuñez and the Politics of Colombian Regionalism 1863-1886, extensively treats the role of federalism in Colombia's historical development during this period. His central thesis, that Rafael Núnez laid the foundations for a stable, centralized Colombian government which had since independence been subjected to the "debilitating forces of regionalism," elevates federalism to the rank of the most important variable in the ideological gulf that separated Liberals and Conservatives throughout the 1850 's, and a paramount issue throughout the period of extreme federalism in Colombia which ended with the beginning of Nuñez second term as president in 1884 . For a brief account of regional economic development in Antioquia, see Alvaro López Toro, Migración y Cambio Social en Antioquia Durante el Siglo XIX (Medellín: Ediciones Hombre Nuevo, 1979). For a good discussion of politics and regionalism, see John W. Sloan, "Regionalism, Political Parties, and Public Policy in Colombia," Inter-American Economic Affairs,33:3, (1979), p. 39.

${ }^{39}$ Park, Rafael Nuñez, p. 10. 
In the major cities, white descendents of Spaniards, today comprising about $20 \%$ of the population, have maintained their dominant positions in large-scale agriculture, commerce, industry, and government. Black ex-slaves, first emancipated by Bolivar to gain the support of the lower classes and later permanently guaranteed their freedom by a midcentury Liberal government, worked in the mining regions of Antioquia and Cauca and later also settled along the Pacific and Atlantic coastal regions.

The topography of Colombia continued to nurture strong regionalist loyalties throughout the nineteenth century. Not until the twentieth century was a communications network built to integrate effectively the Colombian nation. Many isolated mountain regions, large areas of the Pacific coast, the jungle Amazonas region and the vast plains area known simply as Los Llanos (and comprising roughly $60 \%$ of all Colombian land mass) are still not effectively served by adequate transportation links. 40

Today, as has been the case for centuries, the Magdalena River Valley continues to the major transport route in the country. In the nineteenth century, the Magdalena River was the main artery connecting the populous interior to the Atlantic Ocean and Colombia's trading partners in Europe and the United States. August Lemoyne's arduous journey from Le Havre to Bogotá in 1828, related to us by Urrutia, illustrates vividly how the nation's formidable geographical barrier impeded intercourse even on Colombia's primary transport route. "From Le Havre to Santa Marta, on the north coast of Nueva Granada, the trip took 52 days, but between Santa Marta and Bogotá Le Moyne travelled 73 days in the most intense discomfort. The greater part of the trip was spent on the Magdalena River on primitive sampans, in which the passengers and cargo were exposed to all the humidity, heat and insects of the tropics. ${ }^{41}$ Although steam navigation in the second half of the century improved the speed of communications with the outside world, transportation problems persist in the twentieth century.

For the period 1863-1874, Park has divided Colombia into four roughly distinct regional groupings on the basis of geographical unity, economic interest and political identifications. ${ }^{42}$ They are: Cauca, which was a large department whose economic base

40 These regions are however extremely sparsely populated. The major concentrations of population are today well-served by extensive air routes, rail and bus service. Efforts are being made to provide better transportation linkages to both the isolated Pacific coast and Los Llanos.

${ }^{41}$ Urrutia, Development, p. 10.

${ }^{42}$ The following section on the regional groupings in Colombia for this period follows Park's discussion in Rafael Nuñez found on pp. 26-31. 
comprised the export products tobacco and cinchona and gold mining. The second was the tropical north coast, consisting of the states Panama, Bolívar and Magdalena. This area's primary economic resources included the Panama Railway in the isthmus (which provided an important source of income to the federal government, some $\$ 250,000$ annually); Bolívar and Magdalena produced cattle, marine salt destined for the domestic market, and various export crops including tobacco, which was grown in large quantities in Bolívar. ${ }^{43}$ The central government of the United States of Colombia, as Colombia was called during this period, also relied on the ports of Cartagena, Santa Marta and Barranquilla to provide it with substantial revenue from customs receipts. The third regional grouping included prosperous conservative Antioquia and its conservative cousin to the south, Tolima, situated on the Cordillera Central. Both depended on gold mining (in 1872, Antioquia led national production) cattle-ranching and small-scale agricultural production. ${ }^{44}$ Tolima, through which ran the Magdalena, also exported tobacco and cacao. ${ }^{45}$ The final area comprised the states Cundinamarca, Santander and Boyacá located on the slopes of the Cordillera Oriental. Cundinamarca served as a distribution hub for the modest international commerce in a variety of goods produced in Colombia's hot, moderate and cold climates. These included tobacco, sugar, wheat, potatoes, salt and iron implements. ${ }^{46}$ Isolated Boyacá's economy was based on subsistence agriculture and the production of primitive textiles destined for the internal market. Santandér, which boasted a diverse, prosperous economy in the nineteenth century, produced coffee, cacao, sugar and tobacco for export, and also produced rice and textiles geared towards domestic consumption. ${ }^{47}$ In addition to geographical proximity, these three states also shared Liberal majorities in the middle of the nineteenth century.

Strongly marked regionalist feelings are evident today as Costeños, Antioqueños and Vallecaucanos often proudly point to the distinguishing features that make their regions distinct from the capitol and its inhabitants, the Bogotanos (often referred to as Cachacos). Extolling regionalism and individualism, one Colombian observer has written: "Every

\footnotetext{
${ }^{43}$ Park, Rafael Nuñez, p. 26-28.

${ }^{44}$ Park, Rafael Nuñez, p. 29.

${ }^{45}$ Park, Rafael Nuñez., p. 29.

${ }^{46}$ Park, Rafael Nuñez, p. 31.

${ }^{47}$ Park, Rafael Nuñez, p. 32.
} 
section, every valley, every hamlet of Colombia, is a unit which battles for its autonomy and demands its privileges. And this nation, so formed, is individualist, whether Conservative or Liberal; and it would say, if it were consulted honorably and truly, that it loves and defends its individual liberty and detests official co-action and government intervention in personal matters....our social organization, stemming from the Spanish roots and planted in the Indian [social] soil, was, for its greater glory, personalist from the dawn of the Republic." 48

Upon their ascent to power in 1849 , Liberal governments began to seek ways to provide greater local autonomy to fulfill regionalist aspirations. ${ }^{49}$ The social, political and geographic factors mentioned above provided a strong impetus to the federalist movement of the the 1850's and 60's. The result was the extreme federalism of the period of Radical Liberal hegemony that would end with the ascent of the second Nuñez government in 1884 and the failure of the the Radical reaction of 1884-85.

\section{FEDERALISM}

One of the most important early issues dividing the Conservative and Liberal Parties was the extent to which the new Republic was to have a strongly centralized government or a more loosely-knit federation of departments or states. ${ }^{50}$

At the time of independence, no central authority nor a single dominant regional élite had managed to establish itself in power. As early as 1815 in his "Letter from Jamaica", Bolivar himself had predicted regionalist fervor would become an important force in undermining dreams for northern South America's regional unity: "It is very probable that New Granada may not agree to accept a centralized govemment because it is extremely devoted to federation...it will form a separate state which, if it should survive,

${ }^{48}$ Vernon Lee Fluharty, Dance of the Millions, Military Rule and the Social Revolution in Colombia 1930-1956 (Pittsburgh: University of Pittsburgh Press, 1966) quoting Professor Eugenio J. Gómez, pp. 25-26.

${ }^{49}$ Contemporary long-time Liberal champion José María Samper of the dominant Radical wing of the party wrote of these reasons in the following manner: "Very notable differences in race, very distinct customs and economies, climates so varied that they are opposite, formidable mountain ranges that separate the well-populated valleys and upper plateaus, enormous distances lacking good communications, a notable diversity in the conditions of wealth...all of this made it necessary to divide the nation into a reduced number of entities with their own independent administration[s]." Quoted in Park, p. 19.

${ }^{50}$ See Park, Rafael Nuñez, pp. 7-13. 
would be very happy because of its great resources of every kind."51 Despite Bolívar's efforts to forge a united, highly centralized Republic of Gran Colombia in 1819 (which included present-day Colombia, Ecuador, Panama, and after 1822, Venezuela), disintegration would come swiftly. By 1831, the re-christened La Republica de Nueva Granada would include only Panama and Colombia.

After the highly-centralized, royal authority had been swept away by the war for independence, power in the early republic became widely diffused among a cadre of regional caudillos. A single unifying force did not immediately develop to fill the vacuum. The Colombian debate over centralization reached back to the early days of independence to disagreements between the two great revolutionary heroes Símon Bolívar and Francisco de Paula Santandér. Bolívar favored a strong central government while Santandér argued that a federal system was more consistent with republican principles than a centralized system.

The 1821 Constitution of Cúcuta made no allowance for regionalism but was, in the words of Robert Dix, "the embodiment of the best imported conceptions of liberty toward the fulfillment of which, presumably, the new nations were to grow. Thus attempts to apply procedures such as a widespread suffrage often led to electoral fraud.as those who held the real power exerted it to retain control." 52

The modest free-trade reforms enacted by Santander's administration were dismantled by socially conservative governments between the years 1839-1841.53 Drafted following the Civil War of 1840-42, the Constitution of 1843 led to the creation of a more highly centralized state with a strong executive power and also strengthened the Church's role in society. Bergquist adds that policies of these years "favored the Church and sought to arrest the spread of liberal ideology." 54

Economically liberal policies pursued by the nominally conservative administration of Tomás Cipriano de Mósquera (1845-49) focused on improving river transportation links to the Caribbean as well as a modest reduction of tariffs in 1847.55 Election in 1849 of

${ }^{51}$ Henao and Arrubla, History of Colombia, p. 475.

52Dix, The Politics of Colombia, p. 17.

${ }^{53}$ The reforms included a reduction in import duties, legislation to limit Church acquisition of properties through mortmain, as well as efforts to reduce its predominant role in education. Charles W. Bergquist, Coffee and Conflict in Colombia, 1886-1910 (Durham, N.C. Duke University Press, 1978), p. 11.

${ }^{54}$ Bergquist, Coffee, p. 11.

55Park, Rafael Nuñez, p. 14. 
general José Hilario López, candidate of the party now formally organized as Liberal, continued along the path free-trade reforms and heralded a march towards increased federalism that would culminate several years later in the 1863 Rionegro Constitution. This document recognized the individual states of Colombia, referred to as the United States of Colombia, as sovereign and independent entities. ${ }^{56}$

Liberals successfully vanquished a Conservative challenge to federalism in yet another civil war in 1861: extreme federalism under the Pact of Union would help contribute to more than 40 local civil wars as Liberals and Conservatives battled for power in the states. ${ }^{57}$ The 1863 Charter virtually guaranteed state sovereignty in all political and economic affairs. One article even forbade the central government's involvement in local civil wars:

When any portion whatsoever of the citizens in any state shall rise in revolt with the object of overthrowing the existing government and organizing another, the government of the union shall observe the strictest neutrality between the belligerent groups. While the civil war continues in a state, the government of the the union shall maintain its relations with the constitutional government until its authority has been discountenanced in all the territory of the state; and it shall recognize the new government and enter into official relations with it after it shall have been organized in conformity with the national constitution. 58

Federalism would remain a political reality until it was reversed during the centralizing, "Regeneration" government of Rafael Nuñez.

In terms of the ideological battles played out between the Conservatives and Liberals in the nineteenth century, the issue of federalism ranks alongside the role of the Catholic Church in the social and political life of the nation, and the extent that Liberal laissez-faire economic philosophy would dominate the nation's economic orientation. ${ }^{59}$

${ }^{56}$ Dix, The Politics of Colombia, p. 18. Throughout its first century of independence, Colombia underwent several name changes; Gran Colombia (comprised of Venezuela, Colombia and Ecuador), 1819-1830; República de la Nueva Granada, 1832-1857; Estados Unidos de Colombia 1858-1889; from 1889 to the present, República de Colombia.

${ }^{57}$ Henao and Arrubla, History of Colombia, p. 488.

${ }^{58}$ Henao and Arrubla, History of Colombia, p. 488.

${ }^{59}$ The central government's attention to regional interests remains an important feature of Colombian politics today. 
These were the great issues that shaped the outlooks of the major élite protagonists in the armed conflicts that littered nineteenth century Colombian history.

\section{ARTISANS AND THE LIBERAL PARTY: LAS SOCIEDADES DEMOCRATICAS}

In mid-nineteenth century Colombia, independent artisans comprised a sizeable, active force in the nation's socio-economic life. Although no figures exist to inform us how many artisans were represented in the nation's population of nearly two million at mid-century, in 1870 they made up approximately $23 \%$ of Colombia's population of $2,890,637.60$ Table 3:1 shows estimates of the economically active population in 1870 based on figures developed by Urrutia and Henao.

TABLE 3:1

Active Population in 1870

\begin{tabular}{|c|c|c|}
\hline Category & $\begin{array}{l}\text { Number } \\
\text { Percentage }\end{array}$ & \\
\hline Agricultural/Ranch Workers & 816,812 & 55.2 \\
\hline Artisans/Craftsmen & 335,424 & 22.7 \\
\hline Servants & 225,000 & 15.2 \\
\hline Miners & 40,000 & 2.7 \\
\hline Merchants & 26,668 & 1.8 \\
\hline Landowners & 14,373 & 1.0 \\
\hline Vagabonds & 21.000 & 1.4 \\
\hline Total: & $1,4 \longdiv { 7 9 , 2 7 7 }$ & $\overline{100}$ \\
\hline
\end{tabular}

Source: Kalmanovitz, Economía y Nación, Table 3.3, p. 207.

The percentage of independent artisans as a proportion of the total population was probably even higher in 1850 than in 1870 as a result of a number of factors that will be considered below.

As early 1838 , before the formal organization of the two dominant political parties, efforts were undertaken to organize societies to inculcate in the artisans rival conservative and liberal ideologies. One of the earliest artisan societies, the Sociedad Católica, was organized in that year by Monsignor Baluffi, Papal Nuncio in Bogotá, to help teach the

\footnotetext{
${ }^{60}$ Molina, in Las ldeas Socialistas reports $1,812,000$ inhabitants for the year 1843 . The $2,890,637$ figure for 1870 is found in Salomón Kalmanovitz, Economia y Nación: Una Breve Historia de Colombia (Bogotá: Siglo Veintiuno Editores, 1985), p.122. Of the nearly 350,000 individuals classified as artisans, about $71 \%$ were women who divided their time between household chores and activities such as sewing, weaving, making ceramic dishes and kitchen implements, footwear, and clothing.
} 
gospel. ${ }^{61}$ This conservative sociedad attacked the "filosofismo" popular with the liberal intelligentsia.

For their part, liberals created the celebrated sociedades democráticas, influential organizations often comprised of young liberal intellectuals and artisans for the purpose of teaching the artisans about the principles of "liberty, equality and fraternity" and laissezfaire economics. Colombian sociologist Fals Borda argues that the democratic societies were the most important mechanisms for change in Colombia at mid-century because of their initial anti-clerical, anti-colonial, and anti-Hispanic stance. ${ }^{62}$ The sociedades were to become the most important organizations of workers in the nineteenth century, and played an increasingly important political role in the turbulent partisan political struggles of the century.

From their inception, these associations were inextricably interwoven into the fabric of Colombia's two party system, a path--one may note with interest,--that their modern twentieth century counterparts, the trade unions, would also ultimately follow.

Despite the stark reality that the Liberal's free-trade stance was absolutely incompatible with the artisans' desire to maintain their livelihood through protectionist legislation, most of the early Societies of Artisans, many of those established between 1847-1850, were clearly identified with the Liberal party. These in turn were influenced by the Liberal "Generation of 1849," young intellectuals who had been nurtured during the Santandér era of secularizing, anti-traditionalist reforms. The Sociedad de Amigos de los Principios Liberales Bajo el Sistema Democratico (Society of Friends of Liberal Principles Under the Democratic System) for example, was pledged to "uphold under all circumstances our present system of government... and make known the sacred principles of equality, liberty, and fraternity." 63 Another society was more concise in the manner in which it outlined its objectives, "being the same as those professed by the present (Liberal) administration." 64 In order to counteract the growing influence of the Liberal-oriented sociedades democráticas, the Conservatives, with the strong support of the Catholic

\footnotetext{
${ }^{61}$ Funk Harries, "Camilo Torres," p. 182.

62Orlando Fals Borda,. Subversion and Social Change in Colombia (New York, London: Columbia University Press, 1969).

${ }^{63}$ Urrutia, Development, p. 14.

${ }^{64}$ Urrutia, Development, p. 14.
} 
Church, founded several societies of their own in Bogotá, Cali and many other cities throughout Colombia.

The church had participated openly in the ideological battle waged to recruit the artisan since the 1830's. Sowell points out that the church assured that "the proper education, together with votes for Catholic representatives, would prevent the 'infection' of [liberal] ideas from spreading through the nation. "65 The liberal-oriented response was the establishment of La Sociedad Democrática-Republicana de Artesanos i Laboradores Progresistas de la Provincia de Bogotá. The Progresistas (Santandér liberals) launched a newspaper to help educate artisans in democratic theory and liberal ideology, its main objective being to "diffuse...useful knowledge...especially that of politics and morality, so that citizens of the republic can discharge and comply with their rights and obligations with intelligence and pride." 66

The Sociedad Democrática's mouthpiece, El Labrador i Artesano, editorialized on the artisans' responsibility to identify "their interests with those of the state." 67 . Though the president of this society was an artisan, progressive intellectuals from the upper class, including Lorenzo María Lleras and Florentino González, the free-trade theoretician who would serve under Mósquera, actually controlled it. ${ }^{68}$ Prominent progresistas such as Francisco Soto, Vicente Azuero and Rafael Elisio Santandér served as instructors, lecturing on the nature of republican government. ${ }^{69}$

Famous contemporary Liberal writer José María Samper in his Apuntimientos para la historia, described the rapid growth of the Sociedades' influence:

En Bogotá y en las provincias se fundaban, casi repentinamente imprentas y nuevos diarios que aumentaban la combustión de los espíritus en conmoción. Las sociedades democráticas, tomando como modelo la importante Sociedad de Artesanos de Bogotá (que para entonces contaba con cerca de 4.000 miembros) aparecieron sucesivamente llenas de actividad y entusiasmo y con personal numeroso en Cali, Popayán, Buga, Cartago,

65David Lee Sowell, "The Early Latin American Labor Movement: Artisans and Politics in Bogotá, Colombia, 1832-1919," Ph.d. Dissertation University of Florida, (1986), p. 58.

${ }^{66}$ La Bandera Nacional, July 22, 1838, quoted in Sowell, "The Early Latin American Labor Movement," p. 61.

${ }^{67}$ El Labrador i Artesano, Sept 16, 1838, quoted in Sowell, p. 62.

${ }^{68}$ Sowell, "The Early Latin American Labor Movement," p. 62.

${ }^{69}$ Sowell, "The Early Latin American Labor Movement," p. 63. 
Medellín, Rionegro, Mompós, Cartagena, Santa Marta y Pamplona y en casi todas las poblaciones importantes de la República. Ellas eran los centros del movimiento, los focos de la revolución que se efectuaba en las ideas, en las costumbres y en la vida social. Todo el mundo tomaba participación en la política: hombres de estado, ancianos, jóvenes, mujeres, artesanos, sacerdotes, militares. Cada cual significaba algo, porque se había comenzado a practicar la soberanía del número. ${ }^{70}$

The most influential of the sociedades remained under the tutelage of the Liberal Party and, despite critical fractures in the party, was broadly influenced by Liberal ideology. ${ }^{71}$

Events influencing the sociedades included those taking place on the old continent, of which the Bogotá intellectuals kept a close vigil. Jaime Jaramillo Uribe wrote that the sociedades democráticas, "Fueron también el medio social y psicológico en que tomaron cuerpo las influencias políticas de la Revolución Francesa del 48, sobre todo sus tendencias utópicas y románticas que tenían en los sectores artesanales de la misma Francia, su mejor clado de cultivo. Pero las Democráticas en la Nueva Granada no fueron únicamente organizaciones gremiales de artesanos. Fueron también el vehículo político de la "intelillentia" juvenil de las nacientes clases medias y comerciantes, unidas transitorianmente con los artesanos en ciertos objetivos políticos."72 The artisan sociedades early on became dependent on an élite-adopted, foreign-derived Liberal ideology.

In part, this odd alliance between artisan and liberal intellectual can be accounted for by the seduction of ideals such as liberty and brotherhood espoused by the Liberals. Another factor was the utopian socialist rhetoric of equality between classes proclaimed by the young Liberals during meetings of the sociedades, which remained stirring words for reunions of artisans and élite intellectuals, but were never put into practice by these same élites in the real world of trade and profits. Such ideals nevertheless must have exerted a powerful attraction over an artisan class that was consciously seeking recognition for its contributions to society. Artisans shared such lofty ideals advanced by the Liberal Party,

${ }^{70}$ Ricardo Sánchez, Historia Política de la Clase Obrera en Colombia (Bogotá: Editorial la Rosa Roja, 1982), pp. 15-16.

${ }^{71}$ Internal party differences would lead to the creation of two wings of the Liberal party, one, that would be favored by the artisans was more conservative and the other, uncompromising in its support of free trade and feacralism. These differences will presently be discussed in greater detail.

${ }^{72}$ Quoted in Ricardo Sanchez, p. 17. 
though they could have hardly agreed with the Liberal intellectual's advocacy of a laissezfaire economic policy. Free-trade could ultimately only serve to undermine the artisans' economic position in society. The unusual alliance between the élite advocates of laissezfaire and the artisans would prove to be transitory: artisans eventually became painfully aware that their material interests did not coincide with those of the Liberal intelligentsia.

David Sowell in his thesis on the Colombian artisan class provides the most comprehensive description of the artisans in the nineteenth century that has been attempted to date. In it, Sowell effectively argues that the artisans were conscious as a class of their economic role as producers and were intensely proud of that role in society. Many met literary, property and other criteria to be eligible to vote and thus maintained a sense of constituting an integral part of the nation's citizenry. ${ }^{73}$ Comprising a fairly homogeneous class of independent producers up until the 1870 's, the artisans clearly perceived themselves as a distinct group that contributed much to the nation's development. Sowell argues convincingly that the slow process of artisan fragmentation leading to their gradual proletarianization, began in the 1860's as artisans reeled under the impact of unrestricted free-trade and the expansion of the export economy. ${ }^{74}$

Threatened by the advent of new technology, particularly by the establishment of steam navigation on the Magdalena which substantially decreased the cost of transporting goods, and faced with rising competition from abroad, particularly English textiles, the sociedades de artisanos increasingly turned to political activities in order to secure government tariff protection. According to Colombian labor historian Montoya Urrutia, the first recorded instance of Colombian workers' organization occurred in the mid-nineteenth century. ${ }^{75}$ Probably in reaction to the reforms of President Tomás Cipriano de Mosquera, Societies of Artisans with a more explicit political mission than earlier sociedades, began to be established in the capital to defend the artisans' economic interests in the middle of the nineteenth century. Artisans understood well that free trade, "the first step taken by Florentino González, the theoretician of the new liberal economic order, meant the destruction of the Colombian artisan class." 76

${ }^{73}$ Sowell, "The Early Latin American Labor Movement," p. 4-5.

${ }^{74}$ Sowell, "The Early Latin American Labor Movement," p. 38.

${ }^{75}$ Miguel Urrutia in Part One of The Development of the Colombian Labor Movement. ${ }^{76}$ Urrutia, Development, p. 7. 


\section{FEDERALISM AND LIBERAL REFORMS}

The reasons for Liberal support for Federalism have already been discussed at some length, but the consequences of that support has not yet been explored. Federalism was a direct cause of the civil war of 1860 , one of the major factors alongside religion in the 1876 civil war, and it contributed to scores of armed partisan conflicts within and between the states throughout the nineteenth century. Inter-state conflicts were facilitated by legislation which permitted each to maintain an army and by the federal government's permissive stance towards the unrestricted traffic in arms. Molina relates the Liberals' passionate defense of federalism and their antipathy for the Leviathan of centralism in the following way: "Por el amor a la autonomía de las provincias y por el temor a un Ejecutivo Central fuerte, llegaron a un federalismo extravagante que le permitía a los estados asociados tener ejércitos poderosos, sin que el Estado Central pudiera hacerles la guerra, pero no a la inversa." 77

Colombia embarked upon a path of export-oriented, laissez-faire economic policy in 1847. This policy, to the disdain of the artisans who had for the most part supported Liberal candidates, was clearly non-protectionist. In that year, the tariff system was modified and duties were decreased by one-third. ${ }^{78}$ Earlier, after the War of the Supremes, in the 1830s and 40s certain manufactures, such as china, porcelain, iron, (ultimately unsuccessful ventures) and glass, paper, and textiles (lasting ventures) had enjoyed protection by the government. After 1847, laissez-faire policies were implemented by the government. Although a mild non-protectionist duty on certain items was reimposed in 1851, its purpose was to bolster government revenues rather than to preserve troubled domestic industry. Five years later, fluvial taxes imposed on foreign shipping using the Magdalena were eliminated and duty-free status was accorded several Colombian ports. ${ }^{79}$ Under the 35-year Liberal reign, the government did not veer from its free-trade stance.

The economic program undertaken by the Liberals was designed to insert Colombia into the emerging Europe-centered world economy based on free-trade, accumulation of capital, rationalization of production and an abundant and constant supply of raw materials flowing to manufacturing centers in England and later in the century, France, Germany and

\footnotetext{
${ }^{77}$ Molina, Las Ideas Socialistas, p. 109.

${ }^{78}$ Sowell, "The Early Latin American Labor Movement," p. 27.

${ }^{79}$ Sowell, "The Early Latin American Labor Movement," p. 28.
} 
the United States. Colombia's role in this global system was envisioned as one of provider of certain raw materials (especially gold) and agricultural commodities. Exports of agricultural products like sugar and tobacco were encouraged at the same time as import restrictions were relaxed.

Neither of these measures helped the artisans. Cheap imports obviously competed with domestic production, while increased exports in turn created the accumulation of wealth necessary for the élite to purchase conspicuous consumption items from Europe such as tea, jewelry, furniture and china, siphoning away capital that could have otherwise been invested in local manufacturing ventures. Ultimately more damaging to artisan production however, was the unchecked import of high-quality, cheap textiles form England. Between 1864 and 1874, textile imports soared, in turn causing rising trade deficits. ${ }^{80}$ Hardest hit by increases in imports were the artisans, especially those of Santandér and Boyacá,traditional centers for the domestic manufacture of textiles. ${ }^{81}$ Of all imports during the decade $1864-74$, seventy percent consisted of textiles. ${ }^{82}$ Closing off markets to domestic producers was the primary lasting impact of Liberal policies on artisan production. Those who remained solvent after the onslaught, were often forced into the manufacture of coarser goods.

In response to this threat posed to the artisan's livelihood by the free-trade policies, artisans began to organize under the banner of "right to work," as had their counterparts in France in 1848. Cognizant of what free trade would mean to the artisan system of production, the new Sociedades were organized to take a protectionist stance. No longer would they serve as a soapbox for Liberal intellectuals. Free-trade thus became a major point of contention among artisan supporters of Liberalism and ultimately drove a wedge between an artisan-supported faction pledged to procure some protection for artisan industry and the Liberal bourgeois free-traders. ${ }^{83}$

With the 1849 election of Liberal General José Hilario López, legislation liberalizing trade was accelerated and other more overtly political reforms were also put into

${ }^{80}$ See the price indices for imports graphed by Kalmanovitz on page 176 , Economía, using data supplied by Ocampo.

${ }^{81}$ Park, Rafael Nuñez, pp. 59-60. According to Park, more than $20 \%$ of the labor force was involved in artisan activities in Boyacá.

${ }^{82}$ Park, Rafael Nuñez, p. 61.

${ }^{83}$ The two factions, Gólgotas or Radicales, favoring free-trade, and the the Draconianos or Moderados, the conservative, pro-artisan faction, will be discussed at length in Chapter Four. 
place. Universal manhood suffrage was decreed and slavery was abolished definitively in 1851. Laws prohibiting the sale of Indian resguardo land were eliminated in 1850; laws eliminating the tobacco monopolies were finally passed in 1850; the diezmos destined for support of the clergy were also abolished.

Over the next two decades, additional legislation would profoundly affect the development of the Colombian polity. These included the unprecedented (in Latin America) move to separate Church and state, declaring marriage a civil act, eliminating both the ecclesiastical and special military fueros, decreeing freedom of the press, decentralizing government legislative power among the states, reducing the army from 5000 to $800 \mathrm{men}$, and, generally supporting decentralization and a laissez-faire policy toward economic development. ${ }^{84}$ The radicals would maintain power nearly continuously until the 1880's.

Several of the reforms mentioned above merit more careful review. Such reforms as the land reform, the abolition of slavery, free trade legislation, adopting a stance favoring extreme federalism, and anticlerical laws, had a profound impact on Colombian society, particularly the artisan class. We shall look at these more closely in the following section.

\section{EMANCIPATION OF RESGUARDO LANDS AND THE, ABOLITION OF SLAVERY}

Two major mid-century reforms undertaken by the Liberals included the elimination of restrictions on the sale of the Indian Resguardos or communal landholdings (1850) and the definitive abolition of slavery (1852).

The first reform, ending restrictions on the sale of Indian lands ushered in the modern period of enclosures and the creation of many of the great haciendas. Although specific tenancy relations took many forms in the different regions in Colombia, the growth of the haciendas exhibits a general pattern rather typical of rural Latin America in areas of concentrated Indian populations. With the resguardos freed through legislative decree, Indians would accumulate debt to local hacendados by bonowing money to finance the purchase of seeds, or of foodstuffs in times of drought, etc., and would later be forced to sell, piecemeal, their lands as they struggled to pay their debts. Typically, they would become tenants on lands previously held communally by their tribes.

Much of the land moreover, was transformed, switched from the production of agricultural commodities, both subsistence and to fill local market demands, to cattle

${ }^{84}$ Henao and Arrubla, History of Colombia, pp. 468-469. 
ranching, the production of sugar cane and tobacco (depending on climate and soil conditions) and later, to coffee plantations. This led to an increase in food prices and an increase in the labor pool in the towns and villages, both contributing to a further deterioration in artisan standards of living. ${ }^{85}$

The abolition of slavery two years later, though violently opposed by the Conservatives, was embraced by the artisans as a matter of democratic and moral principle. ${ }^{86}$ This act, supported universally by Liberal partisans, most likely also exacerbated competition for urban employment as well as contributed to a general stagnation in wages. The breakup of the resguardos also increased the labor supply and probably had some impact on the stagnation of wages, although to the author's knowledge, no definitive causal link has been empirically established. Frank Safford however, has shown that although the prices of meat, rice, eggs and potatoes tripled and quintupled between $1830-1873$, there was no offsetting increase in wages during this period. ${ }^{87}$

The Liberal objectives for passing such legislation were both ideological and material: on the one hand, the principles of individual liberty and the requisites of democracy demanded the abolition of slavery and the right of the Indian to dispose of his property as he saw fit. Molina suggests another, more material objective: "Se buscaba con las dos medidas liberar mano de obra para que fuera a trabajar en las plantaciones de tabaco y de caña de azúcar, en plena expansión. Se aspiraba, igualmente, a mejorar la capacidad de compra para los géneros y alimentos que iban a producirse o a importarse." 88

Contemporary Liberals themselves viewed the reforms as progressive moves to improve the economy and to maximize individual freedom (freedom to import or, for the Indians, to sell their property). Although the Liberals' intentions may have at least partially been the noble pursuit of individual liberty, the outcome of land tenure patterns was not that which many Liberals had wished. Land reform had the effect of strengthening rural landholders at the expense of the Indians, in many areas transforming the former owners

85Urutia in Development, (p.28) suggests that the enclosure of Indian lands led to frod shortages and higher prices since this land was usually taken out of domestic production.

${ }^{86}$ Molina, Las Ideas Socialistas, p. 108.

${ }^{87}$ Urrutia, Development, p. 29.

${ }^{88}$ Molina, Las Ideas Socialistas, p. 104. 
into tenants. ${ }^{89}$ Miguel Samper wrote years later of the legislation that caused the destruction of the resguardos, "Youth and enthusiasm are no excuse and cannot calm the remorse that he who writes these lines suffers and shall suffer for his participation in this unwise law." 90

\section{THE ROMAN CATHOLIC CHURCH AND LIBERAL REFORMS}

As mentioned in a previous chapter, the Roman Catholic Church in Colombia held a powerful influence over the daily lives of Colombians, represented tremendous wealth in the form of its substantial landholdings and capital, and was a major political actor in the civic affairs of the new Republic. After independence, the patronato real devolved upon the Colombian nation: this included the authority to appoint church personnel and the right to make decisions affecting the establishment of churches, monasteries and missions. ${ }^{91}$ Many of the political conflicts between Conservatives and Liberals throughout Colombian history have revolved around the status of the church's position in society.

The politically "conservative" governments which ruled Nueva Granada from 18301849 afforded the church the protection of the state: Catholicism was declared the exclusive religion of the Republic. Although historians often focus on the absence of a separation between church and state in Colombia at this time, they tend to neglect the fact that in most nations of the world, this was the norm rather than the exception. Even in that most liberal of nations of the period England, individuals who were not members of the Church of England did not enjoy equal rights under the law (individuals from other denominations could not for example attend Oxford University). Austria and the Russian Empire both had official state religions (Roman Catholicism and Eastern Orthodox). Revolutionary France and the United States were the noteable exceptions. At a time when virtually the entire population of Colombia was Catholic (98 per cent of the population was nominally Catholic

${ }^{89} \mathrm{~A}$ contemporary Liberal politician was to write later of this legislation, "The poor Indians were induced to sell their parcels, in which they had their own small house, some independence, and a secure subsistence. In a few years that property fell into the hands of a few landlords, the Indian became a tenant, the land was shifted to grass for cattle raising,and the supply of agricultural goods decreased substantially. All this as the result of a liberty established without previous study of social conditions." Quoted in Urrutia, Development, pp. 27-28.

${ }^{90}$ Urrutia, Development, p. 28.

${ }^{91}$ J. Lloyd Mecham, Church and State in Latin America (Chapel Hill, N.C.: University of North Carolina Press, 1934), p. 115. 
as late as 1970), it is not surprising that the Church and state were not separated under the constitution.

The influence of the church was so pervasive during this period of "conservative" rule that early congresses were often comprised of one-quarter to one-third Catholic clergymen, and prelates frequently held important posts in the administration. Moreover, the Church continued to be the major landholder in Nueva Granada and it continued its virtual monopoly over education. ${ }^{92}$ Although there were undoubtedly many "liberal" priests, some of primitive socialist bent, Catholic bishops were more often than not unabashedly partisan: they preached against the philosophies of Kant, Hegel, Bentham, and the French Philosophes. They also attacked Colombia's strongly republican Masonic Lodges, and organized conservative societies to counteract the liberal sociedades democráticas. ${ }^{93}$

The Liberal ascendency of mid-century posed a particularly potent threat to the Church's prominent position in society. Between 1849 and 1880 Liberal governments curbed the Church's involvement in secular affairs. José López expelled the Jesuits, whom Liberals considered "the most powerful auxiliary of the tremendous opposition which the Conservative party was making against the government."94 The Jesuits were later readmitted for a short period (1858-1861) by the Conservatives, expelled again (1861) by the Liberals and finally allowed to return under the Conservatives in the late 1880's.

In 1853, Congress went a step further. Unprecedented in Latin America, the Liberals officially separated church and state. ${ }^{95}$ Other important legislation which the Liberals were able to enact with a view to limiting the power of the church included: largescale confiscation of ecclesiastical property (except actual church buildings and residences of the clergy); the creation of public schools to end the church's monopoly over education; secularization of cemeteries; the abolition of religious orders as well as the ecclesiastical

${ }^{92}$ See Fernán González, Partidos políticos y poder eclesiastico (Bogotá: Editorial CINEP, 1977) for a good overview of historical relations between church and state as well as J. Lloyd. Mecham Church and State in Latin America (Chapel Hill, N.C.: University of North Carolina Press, 1934).. An earlier paper by the author also discusses the Catholic Church's influence in society. See Curtis D. Curry, The Catholic Church in Colombia: Implications for Development, Unpublished manuscript, (1985).

${ }^{93}$ Funk Harries, "Camilo Torres," p. 181.

${ }^{94}$ Funk-Harries, "Camilo Torres," p. 191.

${ }^{95}$ Mecham, Church and State, p. 151. 
fueros, elimination of the diezmos, the legalization of divorce and a declaration that marriage was to be an obligatory civil ceremony. ${ }^{96}$

These reforms, partly economic aimed at freeing up unproductive lands held by the Church, and partly ideological-eliminating religious influence in matters which Liberals viewed as purely secular, served to antagonize supporters of the Church and helped to create an issue of "morality" that Conservatives could and did exploit to advantage. It also served to charge the partisan conflict between the two parties with the moral dimension that probably heightened the combatants' spirit of engaging in a fight against an evil, irreligious foe or in the case of the Liberals, against an undemocratic, retrograde enemy. Partisans were able to vent these feelings in the more than 50 armed insurrections which occurred between 1863-1885.97

\section{GENERAL ECONOMIC TRENDS AFFECTING ARTISAN PRODUCTION}

In his seminal work, Coffee and Conflict in Colombia: 1886-1910, Charles Bergquist argues that the Liberal rise to power closely parallels the rise and decline of export agriculture, especially tobacco, between 1850 and 1875. He writes "Colombia experienced these export booms beginning in the 1840's with tobacco, later with cinchona bark and to lesser degree with indigo, and finally, near the end of the century, with coffee. During the nineteenth century, however, Colombians found that after an initial boom period, when prices were high, they could not compete with other tropical areas when the world supply had met demand and prices fell."98. This was true of all export products

${ }^{96}$ Mecham, Church and State, p. 155.

${ }^{97}$ Urrutia, Development, p. 47.

${ }^{98}$ Bergquist, Coffee and Conflict in Colombia, $1886-1910$ (Durham: N.C. Duke University Press, 1978), p. 7. In addition to Berguist's work, other important contributions to late nineteenth and early twentieth century economic history utilized in the current study include, Paul William McGreevey's, An Economic History of Colombia (Cambridge, England: 1971) and his later article, "Reinterpreting Colombian Economic History," Journal of Interamerican Studies and World Affairs, Vol 23 No. 3 (August 1981); Salomón Kalmanovitz, Economia y Nación: Una Breve Historia de Colombia, (Bogotá: Siglo Veintiuno Editores, 1985); Marco Palacios, Coffee in Colombia, 1850-1970: An Economic,Social and Political History. London, 1980; Bernardo Tovar Zembrano, La Intervención Economica del Estado en Colombia 1914-1936, (Bogotá: Biblioteca Banco Popular, 1984); Gloria Gaitán, La Lucha Por la Tierra en la Década del 30: Génesis de la Organización Sindical Campesina, (Bogotá: 1984); David Charles Kepner and Jay Henry Soothill, The Banana Empire: A Case of Economic Imperialism (New York, 1967.); Catherine LeGrand, "Labor Acquisition and Social Conflict on the Colombian Frontier, 1850-1936," Latin American Studies, Vol. 16 (1985); Toro, Alvaro Lopez. Migración y Cambio Social en Antioquia Durante el Siglo XIX (Medellín: Ediciones Hombre Nuevo, 1979); Bernardo Tovar Zembrano, La Intervención Economica del Estado en Colombia 1914-1936 (Bogotá: Biblioteca Banco Popular, 1984). 
until world demand for coffee became relatively stable in the early twentieth century. 99 Under Liberal hegemony, Colombia was brought into the political, economic and intellectual mainstream of the gradually industrializing west. 100 This had important consequences for domestic politics and the local market.

In terms of politics, the Liberal ascendency led to the crystallization of two lasting political parties separated if not by disagreement on laissez-faire economics, on important issues including at various times federalism, the Church's role in society, slavery, education, and their respective ideological views (one basically republican the other more strictly hierarchical and paternalistic) of state and society.

The impact on the local market of Liberal policies was also significant. Laissezfaire's dominance led to the gradual impoverishment of a major portion of the nation's population, the artisans, which in turn diminished artisan demand for agricultural products such as cotton and leather, as well as for other products made in Colombia. Also, wages were depressed and purchasing power reduced. This led to the stagnation of the growth of a domestic market. Imports of textiles, furniture, clothes and footwear surged to meet the demands of a small élite who could afford such items. ${ }^{101}$

Extreme federalism also exacerbated the fragmentation of the national economy into a patchwork of different state taxes, duties and varied prices for goods. It also had the effect of retarding the development of a high-quality, integrated national transportation infrastructure, coordinated national economic policy and a national system providing for the uniform education for Colombia's youth.

${ }^{99}$ Although by no means completely stable as current (Summer 1991) coffee prices attest, prices have fluctuated widely earlier in this century as well. McGreevey in An Economic History of Colombia (Cambridge, England: 1971) notes for example, that prices fell 30\% from 1905 to 1932 (although transportation costs which fell by $74 \%$ during the same period, and increased production largely offset losses). A crisis in demand during the first world war however was quite serious. Economists in the 1950's and 1960's, such as Raul Prebisch in Latin America and Sir Arthur Lewis in the Caribbean, recognized the price volatility of export agricultural products and encouraged import substitution and regional integration of markets as strategies to help overcome such disadvantages. For a concise overview of essays discussing the ECLA school, socialism and dependencia theory in Latin America and the Caribbean, see Helio Juaribe, "Marxism and Latin American Development," in Marxism and the Western World (pp. 229-252); Norman Girvan, "The Development of Dependency Economics in the Caribbean and Latin America: Review and Comparison," Social and Economic Studies, Vol. 22, No. 1, (March, 1973); Carlos Iohnson, "Dependency Theory and the Processes of Capitalism and Socialism," Latin American Perspectives, Vols. 30 \& 31, No. 384, (1981); and Harry Targ, "Global Dominance and Dependence, Post-Industrialism, and International Relations Theory," International Studies Quarterly, Vol. 20, no. 3, (Sept. 1976).

${ }^{100}$ Bergquist, Labor, p. 11.

${ }^{101}$ Kalmanovitz, Economia, pp. 132-133. 
Although both federal and state income increased as a result of the surge in imports, federal expenditures outpaced receipts and led to trade deficits in the 1860 's and 70 's. ${ }^{102}$ Between 1865 and 1874 , federal income increased $86 \%$, while import duties collected from the nation's four customs ports, comprised between $64 \%$ and $71 \%$ of of total receipts. ${ }^{103}$ From mid-century, exports also increased, the most important commodities being tobacco until the early 1870's, and coffee after 1880 . Each of these two major developments, unswerving government support for export-import policies and opposition to legislation that would protect domestic producers, as well as decreased transportation costs, served to undermine the position of the artisan.

\section{SOCIAL CONDITIONS: THE DISTINCT WORLDS OF THE ARTISANS AND UPPER CLASS}

What was quotidian life like in Colombia during the middle of the last century? We have already mentioned the tremendous influence of the Catholic Church in the life of the nation-its multiple roles as the social focus of community, as a major political and economic actor, and its part in inflaming partisan passions between the Conservative and Liberal Parties. We have also discussed the development of interests, both material and ideal, that delineated party lines, the clientelist nature of local politics, and the impact of federalism on the historical development of the state.

Without placing these variables into a social context, they become a set of disjointed historical eclectica. What were some of the physical features of daily life in Bogotá and other urban areas? What about life in the countryside? We have also briefly discussed the emerging consciousness of the native-born upper class, but we have yet to discuss how those perceived differences which set them apart form their countrymen affected their decisions and actions regarding Colombia's political, economic and social development (how artisan self-perceptions may have influenced this group's behavior will be treated later).

The Colombian capital, Santa Fe de Bogotá, counted some 20,000 inhabitants around 1815, at a time when a majority of the nation's people lived in the countryside and small villages. As during colonial times writes Colombian historian Henao, "The people of Santa Fe continued to hear mass in the mornings, breakfasted early, and dined between twelve and one. The siesta, or afternoon nap, came next, after which a promenade was in

${ }^{102}$ Park, Rafuel Nuñez, p. 54.

${ }^{103}$ Park, Rafael Nuñez, p. 56. 
order. At twilight, sweets and chocolate were served, and then came supper after the rosary had been recited. At nine o'clock it was bedtime." 104 The "people" to whom Henao and Arrubla refer are those who Fluharty has called the 'Great Families' who "lived, moved and acted on a social plane far above the common herd.... with its tradition of caste, of privilege, of power tenure." 105 The upper class valued not only wealth, but also good manners and education. Journalism, according to Safford and Urrutia was a highly prestigious profession, perhaps second only to that of trade and commerce. ${ }^{106}$

The wealthy citizens of Bogotá lived a life of luxury in the center of the city. This contrasted sharply with the living quarters of the artisans. Henao and Arrubla write eloquently of this contrast:

The old houses were commonly inconvenient, lacking in sanitation and shabby in appearance...The habitations of the artisans lacked windows, had very low doors, and barely composed a single section. The commodious and tastefully arranged houses of the rich were few... a large reception room, a music room, a servant's room beneath the stairway, a pool with running water, guest rooms, a stable, and beautiful plants and fruit trees....In those days municipal services were almost non-existent. The sewage ran through the middle of the streets; many of the latter were unpaved, and the three devoted to commerce had flagstone sidewalks. Hundreds of women called aguateras were engaged in carrying drinkingwater from the public fountains to the private homes. "107

For the vast majority of 30-40,000 individuals who lived in the capital in 1850 however, housing was not as luxurious. 108 One account reports that the majority of houses in the city were cheap, run down and had inadequate sanitation. 109

By the mid 1860's, the economic position of the average artisan had been seriously eroded by successive free-trade legislation, stagnation in wages and a vastly improved

${ }^{104}$ Henao and Arrubla, History of Colombia, p. 240

${ }^{105}$ Fluharty, Dance of the Millions, p. 27.

106U1rutia, Development, p. 19.

${ }^{107}$ Henao and Arrubla, History of Colombia, pp. 462-465.

${ }^{108}$ Sowell, "The Early Latin American Labor Movement," places the population in 1851 at around 30,000-40,000. The 1843 census showed 40,086 inhabitants, and that of 1851, 29,649. (Sowell, p. 37). Sowell, p. 37 also writes the following: "Bogotá had several stylish houses in which rich families had lived. Elsewhere, the dwellings were inferior, for there were few which could be leased for more than fifty pesos annually. Nine-tenths of the city was occupied by those which cost from ten to twenty-five pesos."

${ }^{109}$ Sowell, "The Early Latin American Labor Movement," p. 37. 
transportation infrastructure in response to the needs of the tobacco export economy. Conditions had deteriorated sufficiently that José María Samper wrote in 1867, "Beggars fill the streets and plazas....The worker can not find constant employment, nor can the shop masters count on work; the property owner neither receives rent payments nor new rents; the shop-keeper does not sell, nor buy, nor pay, nor is paid; one sees the importer's wares undisturbed in his store and his payments asleep in his wallet; the capitalist does not receive interest nor the employees salary." 110

In the 1840's and 50's however, the artisans were a vibrant class in Colombian society. One of the central questions posed by social historians is what the variables were that intervened in those short 25 years that led to the precipitous socio-economic decline of the artisan class. In Chapter Four, we will focus on the artisan response to the economic policies of the Liberal Party as well as the ideological divisions that separated what became the mainstream (Gólgota or Radical wing) of the Liberal Party from the more conservative, artisan-supported Draconiano wing. Such divisions would ultimately force the artisans to make an attempt forge a path independent of the Radicals by force of arms.

\section{CONCLUSION}

During the first 25 years following independence, with the exception of the ravages wrought by the war, very few economic and social changes came to Colombia. Local and national government remained an élite affair, though now in the place of Spaniards rose native-born merchants and wealthy landowners. The rebellion against Spain did not produce a democratic social revolution, but merely affected a change in control of the top stratum of the social hierarchy: a transfer of power from the hands of Spanish élites into the hands of creole élites.

Despite deep common interests in maintaining its privileged position in society, this new élite was by no means united in its political visions of what constituted the 'ideal' polity. Two major competing visions emerged after the military victory over the Spanish. Progresistas inspired by the political and economic influence of Santander early on sought to create a society based on British conceptions of laissez-faire economics and a nation organized along secular, federalist principles. On the other end of the political spectrum were those who held a more traditionalist outlook; in broad strokes, they upheld Catholic values, supported movements to create a strong central government, and generally supported measures to provide tariff protection for domestic industry, though they were not

${ }^{110}$ Sowell, "The Early Latin American Labor Movement," p. 29. 
nearly as antagonistic toward free-trade as the Liberals were enthusiastic in its unswerving support.

Artisans played an early role in this emerging partisan struggle, an important but clearly subservient role, as the Catholic Church and its conservative allies sought to limit the spread of liberal political and economic philosophy by creating clubs/societies to combat their influence and the liberals countered with their own sociedades democráticas. Artisans pledged allegiance to one side or the other, pawns in a political struggle that few probably understood.

In this evolving struggle, the surviving historical record indicates that the Liberals emerged victorious in the battle for the minds and souls of the majority of artisans. Egalitarian, democratic, and socialist rhetoric of the Generation of ' 49 , initially.helped convince the artisans that they, despite their differences with the élite strata of the Liberal Party, shared certain fundamental ideals. Ideology clearly played a role. Also, the fact that the Conservatives were more élitist in outlook: democratic and socialist rhetoric were not part of their political repertoire. Conservatives had a more strict hierarchical view of society than did the Liberals, a view in which certain elements, such as campesinos for example, were born to a certain station in life and it was there that they should remain. That is how nature intended society to be organized.

It is a human attribute to be more attracted to groups which hold similarities in common with one's social group than with those who profess pronounced feelings of superiority. Although upper class Liberal youths may have had little in common with working craftsmen as the above section on the major disparity in social and economic living conditions, there was more common ground between these two groups than between the artisans and the élitist Conservatives. It seems logical that artisans would be more inclined to support those who at least stated they had the artisans interests at heart and were in solidarity with their desires for liberty and equality.

The question that eventually would surface however, was what kind of equality and liberty? What did these terms signify for the Liberal élite or the artisan? For the Liberal intellectuals, equality meant that artisans could participate in the democratic process. In a real-world context, this equality only apparently applied to the extent that artisans could participate in the process as long as they recognized their place in society. Also, Liberal ideology played a key role in providing a philosophical foundation for artisan values such as an individualistic work ethic while simultaneously inculcating artisan loyalty to Liberal ideas about subjects such as society, utilitarianism, and allegiance to Liberal governments. By successfully imparting conceptions of good citizenship founded on the principle of 
obedience to established authority (the state, for the Liberals and the Church for the Conservatives), both Liberal and Conservative leaders were able to instill a spirit of conformity among the artisans, effectively channelling organizational energies of artisan groups into partisan political causes.

When artisans challenged the political hegemony of the élite, Liberal intellectuals were quick to jettison their rhetoric of socialism and equality. In the case of liberty and freedom, the concepts also had strikingly different connotations for the two groups. -liberal intellectuals viewed liberty in the context of free commerce and liberty to own property. For the artisans too, liberty had a connotation of ownership, to own their own workshops and tools, but more importantly as the later slogans of the 1849 elections showed, freedom to earn a decent living and freedom from foreign competition.

When the Liberals assumed power, they were free to put their economic ideas into practice. Many of their political and social reforms were supported by the artisans. Artisans supported the abolition of slavery for example. Though many may have been "strong" Catholics, surviving evidence points to support for curbs on power of the Church. Most also did not oppose the decentralized, power-diffusing system implied by federalism. The emancipation of resguardo lands by the Liberals, under which large latifundistas--a majority of which were likely owned by Conservatives--were the primary beneficiaries, was a policy towards which most artisans probably remained indifferent. The large scale enclosures resulting from passage of this law may have also hurt the artisan, since land was taken out of agricultural production and turned into cattle ranching; this resulted in higher prices for basic foodstuffs.

The one major Liberal reform about which artisans were confident in their opposition to it was laissez-faire economics: they knew this measure would have a negative impact on their livelihood. As we will see in the next chapter, the sense of brotherhood, of a shared belief in democracy and freedom, of liberty and equality, the consciousness of being a partner in the creation of a new and better political and economic system for the nation that would benefit all Colombians, the ideals that had led to a virtual alliance between the élite intellectuals and independent craftsmen, would break down soon after the Liberals came to power. That process is the subject of Chapter Four. 


\section{CHAPTER 4}

\section{UTOPIAN SOCIALISM, IDEOLOGY AND CLASS CONFLICT IN THE NINETEENTH CENTURY}

"Todos éramos en ellas socialistas, sin haber estudiado el socialismo ni comprenderlo, enamorados de la palabra, de la neovedad politica y de todas las generosas extravagancias de los escritores franceses; y hablábamos como socialistas con un entusiasmo que alarmaba mucho al general López y a todos los viejos liberales. En uno de mis discursos pronunciados en la tribuna de la Republicana, invoqué en favor de las ideas socialistas e igualadoras al mártir del Gólgota y hablé de este lugar como el Sinaí de la nueva ley social. Pusiéronme en la prensa de oposición el sobrenombre de Gólgota, y luego, por ampliación, nos lo acomodaron a todos los que, también por espiritu de imitación, nos llamábos radicales. En puridad de verdad, no éramos sino unos candorosos y honrados demagogos."

\section{José Maria Samper in his later years 1}

"Habia mucho de romanticismo en los socialistas utópicos, hijos de una época incurablemente romántica Esa hella fue visible en los grupos granadinos que se declararon seguidores del socialismo..."

\section{Gerardo Molina, Las Ideas Socialistas en Colombia ${ }^{2}$}

\section{THE INFLUENCE OF UTOPIAN SOCIALISM}

Utopian socialism imported from Europe exerted an early influence over the minds of a considerable number of the "Generation of '48". Liberal texts acquainted the party's intellectuals with the works of Fourier, Saint Simon, and Robert Owen, and, as contradictory as it may appear to us today, of the British political economists advocating laissez-faire individualism. It appears that a majority were socialists on an ideological plane while advocates of free trade and non-government interference in the more practical sphere of daily economic life. The fact that espousing on the one hand a free trade ideology and socialist-inspired government involvement in the economy on the other pose difficulties that seem impossible to reconcile is testament to the obvious philosophical eclecticism to which the Bogotá Liberal élite were apparently predisposed. In any case, the philosophicalpolitical influence that would endure the vicissitudes of the century would be that of laissezfaire economics.

\footnotetext{
${ }^{1}$ The original appears in Duarte French, Biografía de don Florentino González, pg. 454, quoted in Molina, Las Ideas Socialistas, p. 118.

${ }^{2}$ Molina, Las Ideas Socialistas, p. 117
} 
In general, in terms of economic policies, the Gólgotas sought to create a state bank to replace private banks and, according to Molina, to stimulate domestic production, which in turn they believed, would have the effect of reducing unemployment. Molina, a socialist Colombian historian who has written extensively on the development of liberalism and socialism in Colombia, has described the Gólgotas as romantic utopians. Molina quotes another Colombian source, historian Jaime Jaramillo Uribe, ${ }^{3}$ " que por obra de algunos utopistas y de hombres de letras como Lamartine, Víctor Hugo y Eugenio Sué, adquirió mucha prestancia en nuestro medio la idea de un cristianismo era el que alimentaba los discursos de los jóvenes granadinos que orgullosamente se declaraban socialistas." Nieto Arteta has also written that the Gólgotas were romantics, citing their belief in justice, progress, popular conscience and their radical, almost anarchistic vision of liberalism as proof of their romanticism. ${ }^{4}$

Utopian socialist ideas also gained currency among certain artisan groups. Socialist works were sometimes discussed in the sociedades, and artisans could empathize with the idea that the impersonal market forces of laissez-faire were destroying their livelihood. As Valencia has suggested, "...la introducción de las ideas socialistas permitirá la creación de organizaciones mutuales cuyo fin principal era la defensa de los artesanos en contra de la amenaza real y destructiva del libre cambismo. ${ }^{5}$ These organizations, initially dominated by Liberal intellectuals, eventually came under the control of the literate artisan elite as most of the Gólgotas began to realize the incompatibility between their ideal interests in the protection of artisan industry and government intervention in economic affairs on one hand and their material interests in free trade on the other.

Conservatives, as well as many Liberals, reacted strongly against the new ideas, claiming that socialism was not compatible with Catholic values and that they represented an attack on individual liberty (especially economic liberty). Many viewed socialism as an attack on property, morality and the family.

The Conservatives reacted most vociferously. El Dia proclaimed that the Liberals were "reds", an appellation which seems to have stuck--the Liberals are commonly referred

${ }^{3}$ Molina, Las Ideas Socialistas, p. 116. The source is Jaime Jaramillo Uribe, "Tres etapas de la historia intelectual de Colombia", Revista de la Universidad Nacional, No. 1, octubre-diciembre de 1968, p 89.

${ }^{4}$ Molina, Las Ideas Socialistas, p. 117.

${ }^{5}$ Enrique Valencia, "El Movimiento Obrero Colombiano" in Historia del Movimiento Obrero en América Latina Volume 3, Edited by Pablo González Casanova, (Mexico: Siglo Veintiuno Editores, 1984), p. 21. 
to as the party of the red and the Conservatives the party of the blue. The official Liberal flag is red while the Conservative flag is blue and white. El Dia also argued that Fourier, "habia dicho que el socialismo es la semilla y el comunismo la cosecha, la meta del liberalismo era, en consecuencia, la sociedad comunista y el presidente López su eficaz instrumento." 6 Mariano Ospina and future Conservative president José Eusebio Caro complained of the influence of a handful of "lunatic" left-wing Frenchmen who by condemning marriage destroyed the family and property rights. ${ }^{7}$

Although many prominent Liberals initially supported socialist ideas, there were also important detractors in the the party. Alarmed by ideas that threatened the maintenance of private property, especially Proudhon's exclamation that property was theft, Liberals were quick to launch journalistic sullies against socialism.

Ricardo Vanegas, an important Liberal journalist for the Neo Granadino wrote in the December 27, issue, 1850 :

El derecho al trabajo puede comprenderse de dos maneras: como el derecho de tener ocupación de parte de los particulares empresarios; coo el derecho de tener ocupación de parte del gobierno; Sea como quiera, siempre serán su consecuencia forzosa: la destrucción de la propiedad; la destrucción de la libre concurrencia; la aniquilación de todo principio de libertad.

Unas pocas palabras bastarán para demostrárlo. Cuando dais a un oficial de sastre el perfecto derecho de ser ocupado por el jefe del establecimiento, y de ser ocupado mediante un salario fijo, ¿qué es lo que hacéis? Hacéis de modo que ese jefe de sastrería no tenga libertad para admitir o rehusar los servicios de un obrero, hacéis de modo que una porción del capital del primero pase a manos del último; y desde que obliguéis al jefe de sastrería a dar ocupación en su taller al que se la pida, ya darla a un precio determinado, ¿puede él por ventura decir, soy dueño de mi taller, soy dueño de mi ainero? La propiedad de ese hombre consiste, señores socialistas, en tener abierto o cerrado su taller, en tener o no oficales, en pagarles poco o mucho, en trabajar o no trabajar; y desde que coartéis su libertad en cualquiera de estos respectos, violáis su libertad, y os asemejáis al bandido que consiente en conservar la vida a su víctima, a cambio de eso si da su bolsa...8

If the artisans obtain permanent guarantee to work he further argued, regardless of the quality and quantity of output, eventually industry would be destroyed: "La posibilidad

${ }^{6}$ Molina, Las Ideas Socialistas, p. 140.

${ }^{7}$ Molina, Las Ideas Socialistas, pp. 141-142.

${ }^{8}$ Ricardo Vanegas, Neo Granadino, December 27, 1850, No. 135 quoted in Molina, Las Ideas Socialistas, p. 143. 
en cada obrero de ser o no ocupado, de serlo a buen o mal precio, es el único medio de obtener la perfección en los productos. Pero destruir esta libertad en la concurrencia de los obreros, darles derecho a ser siempre empleados, a obtener siempre una remuneración, trabajen poco o mucho, trabajen bien o mal, y el resultado lógico que obtendréis será la desaparición de la industria." 9

Another opponent to the new ideas was Florentino González, Liberal free-trade theoretician. In 1848, he had argued for a "learned democracy," in which intelligence and property direct the destiny of the people, and opposing universal manhood suffrage as a mistake that could bring about a "barbarian democracy in which equalitarianism and ignorance drown the seeds of happiness and bring disorder and confusion to society." 10 On June 8,1853 , González was assaulted and beaten by a group of men in ruanas, one of the many conflicts that pitted the upper-class Gólgotas against the artisan-backed Draconianos which occurred during the violent weeks following the 1853 presidential elections. ${ }^{11}$

Despite such opposition, that the utopian socialist ideas were at one time very influential in Liberal circles is clear: the very name adopted by the radical wing of the party, the group that held power throughout most of the nearly 30 years of Liberal rule was Gólgota, in honor of the socialist ideals of the Christian martyr. ${ }^{12}$

Since the "socialist" leadership of the day was comprised of Liberal Bogotá merchants, one of the most famous José María Samper, the gulf separating ideological verbiage and material interests quickly became apparent. Samper, who embodied the Liberal spirit of the era, and of the young intellectuals, much later spoke of his youthful socialism and the sociedades democráticas:

Todos éramos en ellas socialistas, sin haber estudiado el socialismo ni comprenderlo, enamorados de la palabra, de la novedad política y de todas las generosas extravagancias de los escritores franceses (lo que también acontecía el doctor Murillo); y hablábamos como socialistas con un entusiasmo que alarmaba mucho al general López y a todos los viejos liberales. En uno de mis discursos pronunciados en la tribuna de la republicana, invoqué al mártir de Gólgota y hablé de este lugar como el

${ }^{9}$ Vanegas, quoted in Molina, Las Ideas Socialistas, p. 143.

${ }^{10}$ Quoted in Urrutia, Development, p. 40.

${ }^{11}$ Urrutia, Development, p. 34.

${ }^{12} \mathrm{By}$ the 1860 's, this wing of the party was more commonly referred to simply as the Radicals. It is important to note that by this time few Radicals clung to "socialist" beliefs. 
Sinaí de la nueva ley social. Pusiéronme en la prensa de oposición el sobrenombre de Gólgota, y luego por ampliación, nos lo acomodaron a todos los que, también por espíritu de imitación, nos llamábamos radicales. En puridad de verdad, no éramos sino unos candorosos y honrados demagogos. ${ }^{13}$

In an article in the Gólgota newspaper Neo-Granadino, Samper articulated his ideas on what constituted socialism:

Yo quiero que el rico y el pobre, el perezoso y el trabajador, el ignorante y el sabio, el hombre de bien y el perdulario, no estén sometidos a un nivel oprobioso e injusto, en sus relaciones individuales. Pero quiero también que los monopolios no existan para que el pobre pueda trabajar como el rico; y éste es el socialismo; quiero que el católoico, el unitario y el islamita tengan igual derecho a profesar su culto, porque todos son hombres y éste es el socialismo. Quiero que la sociedad ofrezca el bien de la educación al ignorante como al sabio, porque quiero el progreso humano, y éste es el socialismo. Quiero que el bueno como el malo, tengan iguales garantías en los tribunales, para que por unos mismos trámites sea condenado el segundo como absuelto el primero y esta igualdad es el socialismo... ${ }^{14}$

In a call for a return to order and stability in Colombia from civil disturbances which had been caused by partisan political battles between Conservatives and Liberals, the same author wrote from Paris in 1861:

Dos sistemas de legislación se disputan en el mundo el predominio de las cuestiones sociales, políticas, religiosas y económicas: el sistema socialista y el de los economistas absolutos. El primero se funda en el absolutismo del Estado, pretende reglamentarlo todo, intervenir en todo, y sustituir la acción del Estado a la del individuo, centralizando toda autoridad. El segundo, partiendo del principio de dejar hacer, aspira a fundar la autonomía individual exclusiva, limitando la acción del gobierno a la simple función de dar seguridad, reprimir la violencia contra todo derecho e impartir justicia. En Hispano-Colombia los dos sistemas han tenido también sus defensores, si bien el socialista es el que ha tenido acepatación general. La Confederación granadina es la sola república que ha ensayado el radicalismo de los economistas, aceptando estos dos principios: libertad plena para el ciudadano, en cuanto no vulnere el derecho ajeno; y abstención del gobierno nacional de injerirse en lo que corresponde principalmente a la actividad individual. ${ }^{15}$

${ }^{13}$ Molina, Las Ideas Socialistas, p. 118.

${ }^{14}$ Quoted in Molina, Las Ideas Socialistas, p. 125.

${ }^{15}$ Taken from Ensayo sobre las revoluciones politicas, quoted in Molina, Las Ideas Socialistas, p 146. 
Here perhaps Samper was engaging in polemics rather than attempting to portray accurately the influence of utopian socialism in the Liberal Party. Samper's claims that the socialist ideas were those accepted by most Liberals is clearly exaggerated according to the evidence of the historical record which shows that no legislation that could be construed as even mildly socialist was adopted during the years of Liberal hegemony. Nevertheless, such statements do indicate that on an 'ideal' plane, socialist ideas must have enjoyed considerable currency. As Urrutia writes, "these romantic socialists believed in the fusion of the classes and that all classes could benefit together. These beliefs were based not on personal experience and actual communication between classes in Bogotá or Paris, but on the intellectual theories common at the time in both capitals...the first uneasy coalitions of intellectuals and artisans that led to the toppling of the conservative regimes in both countries were inspired by similar intellectual illusions. "16 On the material plane of realpolitik, Samper's claim is absurd--free-trade and non-intervention by the state can be said to have literally defined the nineteenth century Liberal era. Later in 1873 in Samper's Los partidos politicos en Colombia, he describes more accurately the mainstream Liberal attitude towards socialism,"...la discussión y la lógica probaban que la veleidad o teoría socialista, nacida únicamente de las exageraciones del sentimiento filantrópico, era incompatible con el verdadero liberalismo, cuya síntesis consistía en la noción del derecho individual y de una espontánea y libre iniciativa de todos los ciudadanos". ${ }^{17}$

Although there were a few prominent voices favoring some form of socialism, most notably Murillo Toro who argued that the state should promote economic growth and development as well as ensure the general well-being of its citizenry, such reforms were soundly rejected in practice by a government and élite that spurned even selective policies that might protect segments of the large artisan population from economic ruin. Murillo Toro argued for a reformist socialism that would help the poorer strata of society, and called for the type of state economic intervention that would become so popular with Uribe Uribe nearly half century later: "La idea socialista es la misma idea republicana; es la parte económica inseparable de la parte política para formar el todo de la República." 18 Unlike José María Samper and his equally famous brother, the merchant and economist Miguel Samper, Murillo Toro rejected the sanctity of laissez faire doctrine, arguing that dejad hacer

${ }^{16}$ Urrutia, Development, p. 22.

${ }^{17}$ Quoted in Molina, Las Ideas Socialistas, p. 147.

${ }^{18}$ Molina, Las Ideas Socialistas, p. 124. 
was also the premise to "o lo que es lo mismo, dejad oprimir, dejad robar, dejad a los lobos que devoren los corderos." 19 Murillo Toro believed that the "free hand" of Adam Smith did not make allowances for the possible growth of monopolies through unchecked accumulation that would in turn eventually destroy competition. Domestic industry, he argued, should be stimulated and protected.

It would be the conservative reign of Rafael Nuñez's regeneration government however, that finally recognized, albeit a case of much too little too late, the importance of selectively protecting domestic industry. Not until the turn of the century, and more permanently, until the 1920's, would the Liberals begin to think about nurturing another strong alliance with elements of the working class. This courtship would be spurred by the new egalitarian, social welfare elements acquired in their ideology. By that time however, their appeals would be directed primarily toward a burgeoning proletariat rather than a stratum of independent artisan producers.

\section{ARTISAN CLASS CONSCIOUSNESS AND CONFLICT}

Most of the major liberalizing reforms enacted during the nineteenth century occurred during the presidencies of Tomás Cipriano de Mosquera (1845-1849) and José Hilario López (1849-53). Florentino González, Mósquera's Minister of the Hacienda, although acting under a nominally Conservative government, initiated the era of liberal reforms designed to stimulate free-trade and bring the Colombian economic system in line with developments in Europe. Having travelled extensively in Europe, and widely considered a cosmopolitan, urbane gentleman conversant with the political economic theories current in England and France, González was impressed by the accumulation of capital he had witnessed in those two nations, and he believed that Nueva Granada's only route to economic growth was through free-trade.

To accomplish this, he was convinced that Colombia had to exploit those areas in which it had a competitive advantage: export agriculture and mining. Thus, he attempted to establish the free cultivation of tobacco and to abolish the diezmos which had long hindered trade. Under his direction, the government also lowered import duties while eliminating other restrictions to trade, and improved mule trails and fluvial transportation routes in order to encourage the development of export and import businesses. ${ }^{20}$ Such a free-trade

${ }^{19}$ Molina, Las Ideas Socialistas, p. 172.

20Molina, Las Ideas Socialistas, p. 98. 
policy would ultimately have a disastrous impact on both handicrafts and the early development of manufacturing businesses in the nation. This was of course a policy by design. González wrote, "La Nueva Granada no cuenta con facilidades para montar fábricas, ni con productos para alimentarlas, ni con consumidores que prefieresen sus manufacturas en concurrencia con las extranjeras." 21

Although artisans comprised a sizeable proportion of Colombia's population in the middle of the nineteenth century as we have discussed, little had been done by the government to provide adequate health care or education to serve this class 22 Mosquera himself noted that:

"Hasta ahora casi nada se ha hecho por la clase pobre e industriosa de la nación. Los hijos de los obreros y artesanos han sido abandonados en nuestros planes de estudio, y solamente se ha cuidado de la intrucción científica, enseñando conjuntamente tantas materias, que la instrucción viene a ser la ciencia de las nomenclaturas, e resulatando, con raras excepciones, empícos en lugar de profesores. No se han fundado escuelas especiales, ya todo esto provee el proyecto que se presenta a las Cámaras, en el que he fundado mis esperanzas para hacer algo en favor de la generación que se levanta." 23

Mósquera's administration did little to improve this situation however.

The artisans represented a fairly homogeneous group in Colombia, linked together by their status as independent producers engaged in skilled trades requiring physical labor. Many were literate, a large number met voter qualifications and regularly exercised this democratic right. A core of dedicated, articulate artisan leaders emerged that according to Sowell "through its relationships with élite political partisans dominated artisan organizations, the artisan press, and the documentation which survives to illustrate the artisans' place in the century." 24 Artisans mobilized for many reasons including to provide a social outlet for artisan groups, to serve a welfare function by providing assistance to members, to pursue specific electoral objectives, and above all, to oppose the free-trade policies that they believed were destroying domestic artisan manufactures. Liberal-inspired

${ }^{21}$ Quoted in Sowell, "The Early Latin American Labor Movement," p. 98.

${ }^{22}$ Both medical care and education had in Hispanic societies traditionally remained the domain of the Catholic Church.

${ }^{23}$ Molina, Las Ideas Socialistas, p. 102

${ }^{24}$ Sowell, "The Early Latin American Labor Movement," p. 6. 
sociedades democráticas and the Conservative sociedades populares had already been created by party élites. These organizations would later serve as artisan vehicles to pursue such goals.

One of the first important artisan mobilizations in defence of their economic interests occurred in reaction to proposed legislation that would reduce tariff rates. More than 200 individuals signed a petition to protest price reductions on items that would compete with artisan goods: "Would it be credible" they asked, "that the same government that we defended would now propose to ruin the useful and laboring class of society, rewarding us for our patriotism..?" 25 Congress nevertheless passed the measure in 1847.26

After this point, the Sociedades, though their by-laws generally prohibited it, became more overtly engaged in political activities. La Sociedad de Artesanos de Bogotá, was founded to accomplish the following purposes; to help its members find work, to inculcate respect for the government, and to provide training and education for its members in matters ranging from reading, writing, democratic theory, military skills and justice to religious instruction. ${ }^{27}$ One contemporary observer wrote in late 1849 that the objectives of the Sociedad were to, "foment industrial knowledge in the working classes of the pueblo, now in order to improve their instruction in areas concerning their political and social rights, and in the end to construct a liberal and patriotic coalition, that will guarantee and sustain our inalienable rights, so many times choked under ignominious despotism." 28

\section{THE LIBERAL PARTY FRACTURES: GÓLGOTAS AND DRACONIANOS}

The Utopian socialists regularly attended the meetings of the Sociedades, delivering lectures on political subjects, social theory, and the 1848 French Revolution. ${ }^{29}$ Despite prominent geographical obstacles, the Sociedades spread quickly to Cali, Sogamoso,

${ }^{25}$ Sowell, "The Early Latin American Labor Movement," p. 78-79.

${ }^{26}$ Sowell, "The Early Latin American Labor Movement," p. 78.

${ }^{27}$ Sowell, "The Early Latin American Labor Movement," p. 98.

${ }^{28}$ Agustín Rodriguez, in a letter dated Oct 1849 , to the director of the Sociedad, quoted in Sowell, p. 98.

${ }^{29}$ These were the so-called Generation of '49. Sowell, "The Early Latin American Labor Movement," p. 96. 
Facatativá, and other cities. Membership grew to around 10,000 nationally with some 1,500 members in Bogotá alone. ${ }^{30}$

Organized artisans played an important, perhaps decisive role in the election of the first Liberal president of the republic, General José Hilario López, in 1849. Since no candidate had received a majority, elections were thrown into Congress. Artisans from the Sociedades threw a barricade around the building where the vote was being taken and noisily filed into the galleries. After two undecisive ballots, and an episode that had led to the galleries being cleared of the artisans, ${ }^{31}$ the third ballot went to López. Conservative Mariano Ospina wrote the now celebrated lines on his ballot, "I vote for General José Hilario López in order that the deputies may not be assassinated." 32

López enjoyed the support of both the artisans and the Radicals, but the actions and support of the artisans probably made the difference in the election. Led by an ancestor of López Pumarejo, the famous twentieth-century Liberal reformer, the tailor Ambrosio López, with his colleagues the ironsmith Emetrio Heredia and the shoemaker Francisco Vasquez Vergara, the artisans believed that as the productive class in society, they had an obligation and a right to participate in the political life of the nation. ${ }^{33}$

Commenting on the precarious alliance between the Liberal intellectuals and the artisans, Molina writes, "Los estudiantes liberales, con una preparación intelectual más rica y con el ansia irreprimible de contribuir al cambio social, vieron que su trinchera lógica estaba al lado de las Sociedades Democráticas. Pero habida cuenta de que aquéllos procedían de un estrato más refinado, rechazaban ciertas prácticas de los artesanos y obreros. Por eso se unieron en la Escuela Republicana, de mucha figuración política en ese entonces. Una vez lanzados a la acción, los jóvenes rebeldes comprendieron que las diferencias entre las dos organizaciones no eran de fondo, por lo cual la Escuela Republicana pasó a ser el brazo intelectual de las Sociedades Democráticas." He adds that they were joined together in their mutual interest of eliminating the colonial structure of the nation's economy to create new types of work. ${ }^{34}$

${ }^{30}$ Sowell provides these estimates, "The Early Latin American Labor Movement," p. 82.

${ }^{31}$ Since the artisans remained outside the building however, they probably still had a somewhat intimidating effect on the deputies.

32 Arrubla and Henao, History of Colombia, p. 455.

${ }^{33}$ Molina, Las Ideas Socialistas, p. 113.

${ }^{34}$ Molina, Las Ideas Socialistas, pp. 113-114. 
Although these common objectives, along with the democratic and equalitarian rhetoric of the Gólgotas, were enough to bring together Radicals and artisans in a temporary alliance, they were not enough to cement the two disparate groups together permanently. Increasingly, the laissez-faire individualism of the Radicals drove a wedge between artisans and the more conservative elements of the Liberal Party.

In 1850, moderate Liberals, who were to become known as the Draconianos, urged Congress to pass legislation protecting artisan industries. One detractor, Juan Nepomuceno Neira strongly deprecated such legislation, claiming "the project is not only anti-economic, it is essentially socialistic or communistic...they want to tax the luxuries of the rich for the benefit of the working class!"35 Lorenzo Maria Lleras retorted in Congress, "If we do not deal with the interests of the laboring class we call artisans, then we do not legislate for the great majority of Colombians." 36 The proposed bill died during the final stages of legislation. ${ }^{37}$

After this event, divisions between the two factions gradually deepened. Radical leaders appeared less frequently at the meetings of the Sociedades. Increasingly, the Escuela Republicana on the other hand, became the domain of the Liberal Bogotá bourgeoisie, the Radical Gólgotas, assuming the atmosphere of a political club.

The president of the most important Sociedad, La Sociedad de Artesanos de Bogotá, Emetrio Heredia sought to insert the issue of protectionism into the Liberal agenda. Although by law the Sociedades were supposed to be apolitical organizations, ${ }^{38}$ Heredia acknowledged in 1849 that "we founded the sociedades to attempt to have spokesmen who would ask for an increase in tariff protection on manufactured goods that could be produced in the country." 39 Ambrosio López, in response to resistance to protectionist measures, published a social history in 1851 in which he claimed that under Liberal

${ }^{35}$ Sowell, "The Early Latin American Labor Movement," p. 112.

${ }^{36}$ Sowell, "The Early Latin American Labor Movement," p. 113.

${ }^{37}$ Sowell, "The Early Latin American Labor Movement," p. 113.

${ }^{38}$ The sociedade's charters generally stated that members should refrain from partisan political activities, though such statements contradicted pledges to support the party in power (Liberals) that were stated in the same documents.

${ }^{39}$ Urrutia, Developmerit, p. 9. 
President López, the Colombian polity had been reduced to an "oligarchy with the name of democracy." 40

It is clear from such comments, and the events that were to unfold in 1854 , that the artisan leadership had become conscious of its interest as a class distinct from other strata in society, and that this artisan élite had become committed to mobilizing artisan opposition to the government's free-trade policies. It also was aware that the interests of the artisan were subservient to those of the affluent and influential Liberal leadership. The majority of artisans had hitched their fortunes to the Liberal party: within a few years however, it had become apparent that the interests of the artisans were incompatible with those of the liberal bourgeoisie.

Liberal reforms, which had seemed progressive, were actually undermining the artisan class. Moreover, as we have mentioned, the abolition of slavery and the destruction of the resguardos, swelled the available pool of urban labor and may have had the effect of causing a serious decline of wages that was detrimental to the artisans. Additionally, the liberalization of the economy, especially legislation easing import duties and restrictions, posed a particularly formidable threat to artisans in the form of increased foreign competition.

\section{THE ARTISAN REPUBLIC OF 1854}

By the time of the 1853 presidential elections, the artisan break with the Radicals was irreversible. Simultaneously, the conflict of interest between the artisans and the objectives of the mainstream (radical) Liberal Party were brought into the open. The sociedades democráticas supported General José María Obando, the Draconiano candidate while the Gólgotas and the bulk of the Bogotá bourgeoisie gave their support to the candidate from Panama, Tomás Herrera. Obando, of humble origins, was very popular with the artisans and often attended the meetings of the Sociedades. ${ }^{41}$ Urrutia writes of Obando, " a guerrilla leader, persecuted, illegitimate and poor, Obando embodied all of the characteristics of the Colombian mestizo." 42

Although the pro-artisan candidate General José María Obando defeated the Radical Tomás Herrera, a predominantly Radical Congress continued to agitate for reforms that

\footnotetext{
${ }^{40}$ Sowell, "The Early Latin American Labor Movement," p. 119.

${ }^{41}$ Urrutia, Development, p. 9.

${ }^{42}$ Urrutia, Development, p. 32.
} 
would be detrimental to the artisans. When in 1853 the Conservatives won a majority in the lower house, an anti-Obando coalition of élites formed between the Conservatives and Radicals. ${ }^{43}$

In May of 1853, the artisans renewed their campaign for protection by submitting a petition to Congress. The effort received bi-partisan support from Bogotá's craft sectors, drawing artisan participation even from the Conservative-dominated Sociedad Popular de Instrucción Mutua i Fraternidad Cristiana. ${ }^{44}$ On May 19, a confrontation between Radical Congressmen and their supporters and the artisans erupted. Two Conservative historians later described the violent episode that took place: "A serious fray got started, in which the two factions were distinguished by their clothes; one group wore ruanas [woolen Colombian ponchos] and the other casacas [coats], in other words, guaches and cachacos. The fight ended with the appearance of President Obando and the Guard, leaving behind one unfortunate artisan dead from knife wounds. 45

Another confrontation between artisans and cachacos also ended in violence on June 8 , with one soldier killed ${ }^{46}$ and several artisans wounded by gunfire from the upperclass youths. ${ }^{47}$ The next day, a pamphlet authored by "un amigo de los artesanos" entitled El valor de los artesanos, appeared in the streets of Bogotá. Un amigo wrote, "in this land democracy is an illusion, we are republicans in theory and slaves in practice.... We are called the sovereign people, but the day that we speak, a rain of stones falls upon our august sovereignty; what can we do to install a positive Democracy? Make our own valiant efforts, and not flee at the sight of the oligarches." 48

Earlier, the Radicals had also attempted to vote the army out of existence, which contributed to the distrust between President Obando, an ex-army general, and Congress. When Congress passed legislation to allow the free trafficking of arms, probably to supply allies of Congress in defense of that body, and then overrode Obando's veto, the Bogotá artisans decided to act. Elsewhere in the Republic, members of various sociedades

${ }^{43}$ Sowell, "The Early Latin American Labor Movement," p. 142.

${ }^{44}$ Sowell, "The Early Latin American Labor Movement," p. 139.

${ }^{45}$ Urrutia, Development, p. 33.

${ }^{46}$ The national guard was primarily made up of artisans.

${ }^{47}$ Urrutia, Development, p. 34.

48 Un amigo de los artesanos, "El valor de los artesanos" (Bogotá, June 9, 1853) quoted in Sowell, p 139. 
democráticas also acted, raiding the Cali armory for example, and walking out with a cache of arms: similar incidents occurred in Chocontá, Santa Marta, Tunja, Zipaquirá, and other towns with active sociedades. 49

The confrontation between the artisans and the Radicals rapidly escalated into armed insurrection a few weeks later. On April 17, 1854 a coup was launched by 600 artisans of the Sociedad Democrática and the small army garrison of Bogota directed against the Liberal Congress. ${ }^{50}$ The city was quickly seized as simultaneous uprisings occurred in Cali and Popayán. Because of the small number of rebels and the overwhelming numerical superiority of the entrenched élites and their rural allies, which included many tenant farmers and peasants, the rebellion was doomed from the beginning.

Colombian sociologist Fals Borda has called the eight-month Artisan Republic, " the only successfully completed revolution in the history of Colombia."51 Indeed, the event was led by the 'working class' of the the day, though in general, the artisans could hardly be portrayed as a progressive force in Colombian society. Artisans sought to minimize the effects of Colombia's insertion into the world economic system by limiting imports and protecting artisan production, in certain respects, to "turn back the clock" to the days before laissez-faire individualism eroded their standard of living. The protection afforded the artisans while Nueva Granada was under Spanish rule, never was matched by Colombian governments after independence had been achieved.

After President Obando had refused to serve as the chief of executive of the newly proclaimed republic, General José María Melo, head of the Bogotá garrison accepted the job of dictator. Thus one of those extremely rare incidences in Colombian history of dictatorship by a military man came to pass. However, Miguel Leon, locksmith and pastpresident of the Bogotá sociedad, has been regarded as the power behind the throne. The actual organizer of the rebellion, Leon worked closely with Melo to chart the course for the artisan republic. Pablo Posada, another key figure in the coup d'etat, founded the artisan paper, $17 \mathrm{de}$ Abril, to serve as the mouthpiece of the new administration. He writes in Number Three "Nosotros somos libres, nosotros somos demócratas, nosotros no habríamos abandonado nuestros talleres, nuestro hogar, nuestras familias, por entregar

${ }^{49}$ Sowell, "The Early Latin American Labor Movement," p. 143.

${ }^{50}$ Urrutia, Development, p. 45.

51 Orlando Fals Borda, Subversion and Social Change in Colombia (New York, London: Columbia University Press, 1969), pp. 85-86. 
nuestra soberanía a un solo hombre; no cambiaremos a ningún precio, nuestro título de ciudadanos por el de súbditos." 52

Elite sectors were quick to react. Although the Radicals and Conservatives had fundamental disagreements on the political level, their common interests in maintaining their class dominance over Colombian society brought them together in a powerful impromptu aliiance to face the common enemy, or in the apt words of Henao and Arrubla, "to save the Republic from the audacious military dictatorship erected by an uncouth soldier."53 In the ensuing months, a government campaign of total repression virtually eliminated the artisan challenge to the established order. Many rebels were killed, including Daniel Leon, and many of those who survived were sent into internal exile in Panama, where a majority succumbed to dysentery and yellow fever, ${ }^{54}$

Along with this crushing defeat, according to Funk-Harries, the entire artisanal system of production suffered a blow from which it would never recover. 55 Although President Mosquera in 1866 and Rafael Nuñez in 1880 courted artisan support by promising tariff reform, the continued influx of cheap European manufactures coupled with the aforementioned developments, undermined the position of the artisans in Colombian society. Urrutia also intimates that this historical episode virtually destroyed artisan production. After writing about the military defeat of the artisans he states, "Thus the first attempt at working class organization in the history of Colombia ended in tragedy....Although the artisan system of production was doomed to disappear, from the point of view of economic development it was unfortunate that it should have been so rapidly destroyed." 56

\section{ARTISAN PRODUCTION IN THE SECOND HALF OF THE NINETEENTH CENTURY}

Actually, Urrutia seems to have been a bit premature in sounding the death knoll of artisan production. As we have mentioned earlier, in 1870 nearly one quarter of the

\footnotetext{
${ }^{52}$ Ricardo Sanchez, Historia Política de la Clase Obrera en Colombia (Bogotá: Editorial la Rosa Roja, 1982), p. 21.
}

${ }^{53}$ Henao and Arrubla, History of Colombia, p. 470.

${ }^{54}$ Urrutia, Development, p. 43.

${ }^{55}$ Funk Harries, "Camilo Torres," p. 203. Urrutia, Development, shares this view, pp. 41-43.

${ }^{56}$ Urrutia, Development, p. 43. 
population was engaged in some form of artisan production. David Sowell notes that artisans remained active in politics even after the 1854 debacle, exerting some influence in local, regional and national politics. These are indications that artisans were still an important force in Colombian society.

What is clear however, is the fact that the artisans' strategy of allying themselves to the Liberals had not succeeded in bringing them tariff relief; nor had their rebellion against Congress, which ultimately sought to re-create a democratic society in the image of the artisan, succeeded in giving them a vital voice in national affairs. Also demonstrated by this mid-century event was the incredible ability of the landed élite and commercial bourgeoisie to collaborate effectively, placing their partisan disagreements aside, when faced by a challenge from below. However, perhaps the most striking outcome of the conflict was the uncanny resilience of the artisans to survive such an élite offensive, regroup and continue to battle for their economic survival through other courses of action until they became permanently fragmented in the 1880's and beyond with the appearance of a salaried proletariat.

In the 1850's and 1860's however, the artisans appear to have remained a vibrant force in society. Several publications appeared, including El Artesano, which began publication two short years years after the failure of the artisan coup. It again set about the business of attacking Mósquera's second administration. ${ }^{57}$ El Obrero began publication in 1864 and La Alianza, the official organ of La Sociedad de Unión de Artesanos in 1866, indicating that the artisans had not yet disappeared from Colombia. ${ }^{58}$ In fact, during the Civil War of 1862 , the artisan-comprised national guard repelled two attacks by Conservative armies on Bogotá, while the Liberal army was launching an offensive in Antioquia, the heart of Colombian conservatism. ${ }^{59}$ Although the events of 1854 had eliminated the artisan challenge to the entrenched élite's control of the reigns of government, it had not ended their productive role in society. Moreover, artisan production remained the dominant non-agricultural productive force in Colombia through the 1920's.

The artisans briefly attempted to chart a course independent of the dominant élites in the late 1860 's. Still maintaining their self-portrait as the productive force in society, artisan organizations sought to create an artisan consciousness that could help bind

\footnotetext{
${ }^{57}$ Sowell, Development, p. 203.

${ }^{58}$ Sowell, "The Early Latin American Labor Movement," p. 205.

${ }^{59}$ Sowell, "The Early Latin American Labor Movement," p. 203.
} 
disparate trades together in order to affect changes in governmental policy advantageous to their class. Through his study of the Bogotá artisans, David Sowell has added much to our understanding of the Bogotá artisans in the late nineteenth and early twentieth centuries, a subject heretofore neglected by both labor and social historians. In his review of the volumes of La Alianza, the publication of the Sociedad de Artesanos, Sowell explores the political ideology and self-perceptions of the artisans. Here, I will quote extensively from his review:

Artisans viewed the ideal republic as a collective social organism--a nation-composed of various elements, each of which contributed to its symbiotic operation. Citizens of the nation, because they were created by God, were equal at birth; no distinctions of nobility or inferiority divided the society. After birth, stratification emerged based upon one's positive social contributions, or one's negative manipulative abilities. Positive contributions consisted of virtuous behavior or work, while negative factors of stratification included inherited privilege, force of arms, or political gamonalismo.

Just as God's creation had endowed humanity with equality, so too did it dictate a moral basis for social well-being.... The family was held in high esteem as the primary vehicle for diffusion of these principles... Without education, good citizenship was difficult because ignorance allowed for anti-republican manipulation....A nation, as conceived by the artisans, was composed of numerous different social elements, foremost being producers and consumers. Craftsmen stressed the positive social importance of work and production, suggesting that people who consumed without producing were violating the will of God...W Workers produced by their labor and skills, while their social opposites consumed and caused capital to circulate. Camacho [the article's author] equated these two functions with the poor and rich, noting that the poor had the social obligation to work and produce, while the rich must consume and stimulate the arts. In a nation in which property's proper social function was fulfilled, neither the rich nor the poor abused their role, and a balance existed between producers and consumers. ${ }^{60}$

Artisan leaders believed that the state had an obligation to keep the peace, rule in the interests of the people, and support the nation's industry. In return, the artisans were pledged to render allegiance to the government. In one article, the author argued that

${ }^{60}$ Sowell drew this information from the Artisan paper La Alianza, in the following issues: Oct 10, Oct. 20, Dec 1, 1866, Jan. 10, 20, Feb. 13, Mar 4, Apr. 3, April 13, May 14, August 10, Sept 5, 1867, Jan. 4, Jan 25, Feb. 8, 15, 22, 25, 29, Mar. 4, 14, Apr, 4, Apr. 11,1868. See Sowell, "The Early Latin American Labor Movement," pp. 206-213. 
artisans must avoid engaging in partisan politics since their historical experience was one of manipulation by the established parties. ${ }^{61}$

The artisans had finally come to the realization that they had been ill-served by the existing parties in Colombia, and believed that by virtue of their productive role as creators of society's wealth, that they should be accorded a worthy role in society. Possessing a strong work ethic, as much a result of their independent status as craftsmen as from any well-articulated philosophical position, the artisans resented the class that they perceived to be idle; they were aware of the fact that this class was the same one that was undermining their economic existence by supporting free-trade at the expense of artisan industry. Artisans believed that the best strategy for them to follow would be to maximize their opportunities to serve as an effective pressure group, regardless of the party in power, as well as support individual artisans by providing education so that they would be able to participate actively in the affairs of the nation, were committed to support of the most elemental social unit, the family, and by urging artisan cohesiveness or solidarity.

\section{RAFAEL NUÑEZ AND THE ARTISANS}

In the last quarter of the century, artisans were less capable of mounting an organized united front to bring artisan interests to the fore of societal concerns, as they had attempted to do in the 1850's and 60's. ${ }^{62}$ This was true despite, or perhaps partially as a result of modest support artisans received from Rafael Nuñez's Regeneration government. The Liberal and Conservative Parties all but ceased to woo actively artisan support, and it is generally agreed that artisan industry went into serious decline after 1870. Sowell attributes this to fragmentation of the artisan class itself as wage labor began to displace the independent craftsman as the most common form of labor.

Artisans now had an interest in mounting anti free-trade campaigns against Liberal government policies since they sought to distance themselves from partisan politics. Their experience in the innumerable armed conflicts of the 1850-1880 period, particularly with the civil war of 1859-62 must have frustrated artisan hopes of receiving the reward of tariff protection in return for the fealty they demonstrated to the Liberal government. Suggests Sowell, these experiences helped to "reinforce a feeling of political exploitation among

\footnotetext{
${ }^{61}$ Sowell, "The Early Latin American Labor Movement," pp. 206-213.

${ }^{62}$ Sowell, "The Early Latin American Labor Movement," pp. 360-361.
} 
craftsmen, as once again they were used as canon fodder, only to be forgotten when the battles ended." 63

Craftsmen did lend their electoral support to Rafael Nuñez's socially conservative government. Although Nuñez had long been an important figure in the Liberal Party and was elected as a Liberal president, under his administration several extremely conservative reforms were enacted. Such reforms not only included moderate protection for the artisans, but also led to the reestablishment of a strong centralist government and the return of the Catholic Church to its privileged position in society. The reforms of the Regeneration are enshrined in the Constitution of 1886 , which with minor modifications is still in force today. ${ }^{64}$ As the Regeneration government's policies became more conservative, Nuñez's new Independent Party faced a backlash from the Radicals as Conservative ranks supporting Regeneration policies swelled. The backlash culminated in the Civil War of 1885 , in which Radicals rose against the Nuñista-Conservative alliance. With their victory over the Radicals, Conservatives came to control the government and would not relinquish power for nearly 50 years.

Nunez had become convinced that neither the laissez-faire policies of the Radicals nor the extreme federalism put into place during the years of Radical hegemony, had served the interests of the nation. He spoke in his first term's inaugural speech of the contemporary state of the economy:

Our agriculture is barely in its infancy. Our crafts remain stationary. Our vast territorial expanse counts only a few kilometers of railroads. Statistical tables reveal the disheartening fact that for several years we have not exported enough to pay for what we import. This economic ambivalence, if it continues, will even give rise to the alarming conjecture that the Colombian people consume more than they produce. And in any case, it is evident that the labor of the nation is in decay. The formidable calamity of public poverty is thus approaching the threshold. "65

Surprisingly, the protective tariffs proposed by Nuñez during his first administration were opposed by many Conservatives who feared that they would would

${ }^{63}$ Sowell, "The Early Latin American Labor Movement," p. 359.

${ }^{64}$ The 104 year-old conservative constitution has been amended. In 1990, Colombia's four largest political parties held a referendum on December 9 to determine whether or not they approve of the constituent assembly and the agenda for its meeting. The agenda was finally approved and a new constitution was drawn up in 1991.

65Park, Rafael Nuñez, p. 196. 
cause prices to rise as well as contribute to a possible revitalized threat from the lower strata of society; they were opposed by Liberals on the grounds that such a move would constitute a betrayal of the sacrosanct policy of laissez-faire. ${ }^{66}$

Nuñez's support of the artisans was probably a recognition of his belief in the artisans' importance to Colombian society. He wrote, "Is it suitable or not that a union of artisans exists to serve as a mediating force between the social element which directs and governs and the illiterate mass which forms the base of the pyramid?"67 It is clear also that Nuñez wished to spur domestic production to reduce reliance on foreign imports for items that could readily be produced in Colombia. Economic historian Salomón Kalmanovitz offers a slightly different interpretation in the following passage:

Más adelante, muchos artesanos se identificaron con el gobierno impregnado de conservadurismo de la Regeneración que ofreció alguna protección a las manufacturas del país, más con el ánimo de controlar la balanza de pagos de otorgar garantías efectivas a la artesanía, para no hablar de la industria fabril, pues el proyecto de los Regeneradores consistió más bien en desarrollar la gran hacienda cafetera. ${ }^{68}$

In addition to tariffs that protected tailors, shoemakers, and furniture makers, a national bank was founded in 1881, government monopolies were created for cigarette, cigar and match production, and Nuñez supported the creation of the School of Arts and Trades, where imported vocational teachers were to instruct craftsmen using state of the art production techniques and methods. ${ }^{69}$ The school did not open until $1891 .{ }^{70}$

Artisan relations with the Regeneration government deteriorated after dozens of workers were killed and hundreds arrested during an 1893 protest in reaction to an article written by a priest that claimed that the artisans drank too much. In actuality, this spontaneous outburst was probably as much a result of pent-up frustration from the

\footnotetext{
${ }^{66}$ Park, Rafael Nuñez, p. 199.

${ }^{67}$ Park, Rafuel Nuñez, p. 200.

${ }^{68}$ Kalmanovitz, Economia, p. 133.

${ }^{69}$ Sowell, "The Early Latin American Labor Movement," pp. 33-34.

${ }^{70}$ Sowell, "The Early Latin American Labor Movement," pp. 33-34.
} 
intolerably high food prices and rents over the period 1889-92 as to the specific incident which provoked it. ${ }^{71}$

Even the Regeneration reforms were only selectively protectionist, and in the face of precipitously rising food and rent prices and concomitant stagnation in wage levels, probably did little to ameliorate the artisans' plight. As Park writes, "because of the government's fiscal dependence on import duties, the 1880 tariff law sought to restore balance between imports and exports rather than a move away from free trade."72 Moreover, given the government response in the 1893 riot, it would not be an exaggeration to say that once again artisan appeal to partisan politics was only moderately successful, probably only to the extent that the interests of the government in power overlapped in one way or another with the interests of the artisans rather than the result of effective sustained artisan pressure on the élite-dominated political structure.

Aside from Sowell's work, which looks at organized artisan groups, little research has been done on the plight of those artisans displaced by the rapid economic changes of the second half of the nineteenth century. Historian Helen Delpar writes, "It is generally believed that the low tariff policy introduced in 1846 had a deleterious effect on Colombian handicrafts, but we do not know what happened to the individuals displaced by foreign competition or whether the fate of artisans throughout the country were identical."73 Catherine Le Grand has noted that many artisans were drawn toward the western frontier during the second half of the nineteenth century and the first decade of the twentieth. ${ }^{74}$ Lured by the promise of free land, artisans as well as peasants from Cundinamarca, Tolima and southern Santandér, displayed a remarkable readiness to migrate. Others were attracted to the relatively high wages in the coffee industry of to the rapidly expanding banana industry along the Caribbean coast.

After 1870, there was a movement in Antioquia towards growing coffee as gold exports began to decline. This move was accompanied by the creation of a nucleus of artisans who, using imported equipment, manufactured items to be used in the domestic

${ }^{71}$ Sowell, "The Early Latin American Labor Movement," pp. 271.

${ }^{72}$ Park, Rafael Nuñez, p. 189.

${ }^{73}$ Helen Delpar, Red Against Blue: The Liberal Party in Colombian Politics, (Alabama: The University of Alabama Press, 1981), p.29.

${ }^{74}$ Catherine LeGrand, "Labor Acquisition and Social Conflict on The Colombian Frontier," Latin American Studies, (Vol. 16, 1985), p. 29. 
coffee and mining industries. Along with mining and coffee equipment, two ironworks and two factories engaged in smelting silver, and a bank were also created with foreign capital. ${ }^{75}$ In 1864, a School of Arts and Crafts was created that by 1880 produced 20-30 qualified artisans to man the aforementioned industries. ${ }^{76}$ At this time, Antioquia counted as much as 20 percent of its population among the ranks of urban dwellers compared to around six percent nationally. ${ }^{77}$

In other parts of the republic, artisan reaction to the economic changes undermining their role in society took more violent forms than in Antioquia. In Santandér for example, violent response to an incident involving the Sociedad Democrática, La Culebra Pico de Oro, in Bucaramanga led to the death of two German businessmen and a Conservative landowner. This incident writes Kalmanovitz, showed how much the artisans resented the foreign merchants. Also, he adds, it showed a "profundo odio del pueblo trabajador el notable bumangués y en particular contra los comerciantes más grandes y prósperos que se habían enriquecido con el tráfico de tabaco y el añil; de otra parte, un odio nacional contra los comerciantes alemanes como malignos por Pedro J. Callejas, uno de los dirigentes de la asonada." 78 Though relatively rare after the great uprising of 1854 , spontaneous acts of violent protest by artisans occurred sporadically throughout the closing decades of the nineteenth century.

\section{THE MUTUALIST SOCIETIES}

The mutualist societies, which were established in the last two decades before the turn of the century, came to dominate the Colombian labor scene until the end of World War I. ${ }^{79}$ Mutualist societies were created to benefit workers through mutual cooperation. These rudimentary workers' organizations were extremely passive and generally apolitical. They provided a social focal point for artisans to gather, often provided modest unemployment benefits for their members and helped to provide health care as well as spiritual care for the souls of their artisan membership. The example of the fate of the artisan societies and the artisans' painful experience with partisan politics were still fresh in

${ }^{75}$ Kalmanovitz, Economía, p. 204.

${ }^{76}$ Kalmanovitz, Economía, p. 204

${ }^{77}$ Kalmanovitz, Economía, p. 204.

${ }^{78}$ Kalmanovitz, Economía, p. 205.

${ }^{79}$ Moises Troncoso and Ben Burnett, The Rise of the Latin American Labor Movement (New York: Bookman Associates United Printing Services, 1960), p.82. 
the minds of potential labor organizers. Moreover, the economic climate was not conducive to the development of a new challenge by workers until the second decade of the twentieth century.

Hobart Spalding has said that although the Mutual Aid Societies did not continue to flourish after the first decades of the twentieth century, "nevertheless they provided many workers with important organizational experience and sowed intellectual seeds that later bore fruit under the impact of more militant working class ideologies." 80 An organization capable of representing the workers' interests as well as of confronting the government and intransigent employers had to await the emergence of the anarcho-syndicalist and socialist labor organizations in the second decade of the twentieth century.

The process of proletarianization of the Colombian worker was a gradual and painful one. While artisans were progressively impoverished by their inability to compete with the flood of cheap foreign manufactures in the second half of the nineteenth century, few industries organized on the basis of wage labor were established to absorb the surplus of labor in urban areas. Goods that had formerly been produced by Colombia's crafts industries were simply replaced by imported items. The Radicals' political liberal free-trade ideology had been so pervasive that it did not occur to Liberals that the nation might not be able to survive on export agriculture receipts and customs duties alone.

Before Nuñez, few seemed to be concerned with the deleterious affects on social and economic development brought about from an over-reliance on laissez-faire-diminished income for the middling classes, higher food prices as a result of the move away from the production of domestic agricultural staples to export crops, and the inevitable, rapid pauperization of a sizeable, often literate, segment of the nation's population. One obvious reason for the Liberal government's virtual indifference to industrial development in Colombia was its single-minded focus on export-import, stressing the preeminence of export agricultural commodities. Kalmanovitz offers an additional reason for the conspicuous absence of any substantial industrial development during the nineteenth century in his economic study of Colombia:

La productividad del trabajo en la artensanía es entonces tan baja como en la agricultra y no deja en manos del productor una acumulación de capital en cuantía apreciable. Aun la qe amase el comerciante no será muy grande, a menos que éste consiga intermediar el trabajo de numerosos artesanos. En muy pocos casos reales, de aquel comerciante habrá de surgir el industrial

${ }^{80}$ Hobart Spalding Jr., Organized Labor in Latin America: Historical Case Studies of Urban Worker in Dependent Societies, (New York, 1977), p.15. 
que contrata el trabajo con dada unidad doméstica separada para más adelante ensamblar el producto en la fábrica...es bastante hipotético afirmar que tal sistema se encaminaba hacia el capitalismo y que la política librecambista del medio siglo le cerró la vía. Esto sería suponer que la única condición para que surja un sistema capitalista industrial es la existencia de la protección arancelaria. Pero, además de la protección, el capitalismo surge de profundas transformaciones de las fuerzas productivas y del desarrollo de las clases burguesas (proletarios y capitalistas), precedido quizá por la liberación de los campesinos atados a la tierra, que se transforman en propietarious de aparceros libres. ${ }^{81}$

Bergquist argues on the other hand, along dependentista lines, that Colombia was already part of the world capitalist economic system by the end of the nineteenth century, having assumed the role of provider of raw materials and agricultural goods to rapidly industrializing Europe and the United States. In his view, Colombia was defacto part of the world economic system by virtue of its reliance on tobacco and later, coffee exports. In any case, it seems clear that by the end of the century, the nation was poised to embark upon a path of economic development that relied primarily on the production of export crops to the more economically advanced nations of the North Atlantic.

The first three decades of the twentieth century in Colombia would witness the development of a wage-earning proletariat and the accumulation of domestic and foreign capital in the nation. Coffee's stellar rise in the closing decades of the nineteenth century would presage the expansion of viable public works programs geared toward improving Colombia's export infrastructure and help to finance productive investments in industrial and other export agriculture sectors.

The first decades of the new century would also see organized labor renew its attempts to chart a course independent of the nation's two dominant political parties. This course was envisioned by labor as one which would allow workers to contribute to the creation of a new democratic and equalitarian Colombia in which labor would be recognized for its essential role as the productive force in society. Before proceeding to a discussion of this renewed struggle of the labor movement to assert its autonomy, however, Chapter Five will trace the development of labor in the countryside that made the nation's industrial expansion possible.

81 Kalmanovitz, Economia, p. 123. See also Dix, The Politics of Colombia, p. 21 for a view that supports Kalmanovitz' argument. 


\section{CONCLUSION}

From the earliest attempts at labor organization, one can detect a pattern of élite support for craft organizations in attempts to enlist workingmen into the partisan political struggles between competing dominant élite interests. Those interests were politically embodied in the Conservative and Liberal Parties. Two ancillary objectives of the Colombian élite were to attempt to inculcate loyalty and conformity, as well as to control the artisan class. The following typical passage from a contemporary newspaper article directed at an artisan audience relates a lecture in one of the early sociedades in 1838 :

Ezequiel Rojas lectured on the science of morality, an address based directly upon the utilitarian principle that happiness motivates human behavior. Correct conduct, he explained, was based upon the need to provide for the good of the family, or of those close to the individual. If one did not work or were lazy, the ensuing hunger and vagrancy would plague both family and society. Work, on the other hand, gave the individual the means to pursue desires, provide for a family, and improve the general society. The goodness that ensued was the essence of morality. Prayer, Rojas reasoned, was the manner by which one thought about morality, by pondering the course of action which would produce the most good and general happiness. ${ }^{82}$

Paternalistic and condescending are words that succinctly describe mainstream élite attitudes towards the artisans. Workers were clearly viewed as belonging to a social plane distinet from that to which the Colombian élite belonged, perhaps not on the bottom, which was occupied by freed negro slaves and peasants, but certainly well below the apex where dwelled the tiny number of aristocratic landholders and the influential commercial bourgeoisie of the larger urban areas, particularly Bogotá. This was an élite that on occasion felt a powerful sense of paternalistic social responsibility towards those less fortunate below, but an élite which also viewed as the natural state of society the fact that the fruits of the nation flowed top downward. Under the Liberal hegemony of the nineteenth century, even the celebrated paternalistic concern said to be characteristic of the dominant classes in Hispanic societies was conspicuously absent: laissez-faire individualism ruled the thought and actions of Liberal statesmen.

Even though artisans found some relief in the policies of the Regeneration, artisans were still viewed as the "mediating force," in the words of Rafael Nuñez, between the élite and the "baser" elements of society. Moreover, a later Regeneration administration, by that

${ }^{82}$ El Labrador i Artesano, Nov 11, 1838 quoted in Sowell, "The Early Latin American Labor Movement," p. 63. 
time thoroughly dominated by Conservatives, did not hesitate to use deadly government force to repress a riot in 1893 said to have been initiated by artisans. Conservatives held ambiguous views towards the artisans, recruiting support from them when politically expedient to do so, but maintaining a wary vigilance over their actions. By the 1880 's the Conservative press, including El Deber and El Conservador, and most of the party's leadership strongly opposed the imposition of tariffs that would threaten Colombia's freetrade stance. ${ }^{83}$ The Conservatives' wary attitude towards the artisan is illustrated by Conservative Carlos Martínez Silva's exhortation in opposition to the protective tariff in 1880 , "Why would one wish to return to the scenes of 1853 , by now completely forgotten?"84

The artisans themselves, as has already been shown, had a very different view of themselves and their role in national development. They exhibited a high degree of consciousness of themselves as constituting a class distinct from those who consume and those who do not produce physical goods. Artisans saw themselves as the honest, hardworking, productive force in society, and they believed that their quest for the 'right to work' was just. Moreover, artisans also believed themselves patriots who had consistently served as the vanguard in Colombia's numerous civil wars and rebellions that plagued the second half of the nineteenth century. Nevertheless, despite their loyalty to Patria and Party, their demands for protection were never fully addressed. Even after Rafael Nuñez's rise to power in 1880 , only a select few artisan industries benefitted from the modest protection afforded by the conservative government.

Only during the brief period of 1853-54 did artisans mount a political challenge to the existing system. With election to the executive of one of their own, General José Hilario López, artisans began to realize that their economic interests were incompatible with the interests of the liberal bourgeoisie. Molina quotes Dario Ortiz Vidales who wrote of the uprising, "Por primera vez desde la época de la Independencia, las clases populares buscaron soluciones políticas, sociales y económicas por su cuenta, sin detenerse a pensar si éstas eran del agrado o no de los prepotentes detentadores del poder, que sólo toleraban que el pueblo fuera lanzado a la guerra, cuando ésta convenía a sus personales intereses." ${ }^{85}$

\footnotetext{
${ }^{83}$ Park, Rafael Nuñez, p. 199.

${ }^{84}$ Park, Rafael Nuñez, p. 199.

${ }^{85}$ Molina, Las Ideas Socialistas, p. 137.
} 
Artisans had become conscious of themselves as a class with distinct interests from those who wielded social, political and economic power in society.

After a quick succession of events led to a coup d'état, an artisan republic was declared. The new government's power actually extended to Colombia's major urban areas, including Bogotá, where artisans were numerically strong. An alliance between the established élite comprised of both Conservatives and Liberals, rapidly mounted a counterrevolution with the support of their campesino clients. After eight months, Melo and the artisans were defeated.

After the catastrophe of 1854 , repeated attempts to develop a voice within the framework of the existing poli-class parties that would permit artisans to serve as a powerful pressure group, met with limited success, and never achieved artisan socioeconomic objectives. Mounting a direct challenge to the existing system had failed miserably. Artisans resumed their pre-Melo strategy of supporting the existing parties, particularly the same Liberal party which had abandoned them in 1854. Despite efforts to draw attention to their productive roles in party affairs by serving in Liberal and Conservative armies and by mobilizing the artisan vote during important electoral campaigns, artisan demands were virtually ignored until the last two decades of the century. By that time, Colombian craft industries were in serious, irreversible decline. This partisan political strategy also failed to achieve artisan goals. The artisans' only remaining survival strategy was to "look out for their own" by attending as well as they could to their economic needs and eschewing direct political action. Only much later were they able to seek out allies among the rising class of wage-earning workers in the incipient industries taking root in the nation, as well as workers in the expanding transportation sector.

Although the artisans were never able to mount a well-organized, effective political mobilization to defend their interests after the 1870 's, they did play the central role in the organization of the Mutual Aid Societies in the closing years of the nineteenth century, and they were also active in the early development of socialist and anarchist unions in the first three decades of the twentieth. Victor Alba in his overview of Latin American labor, argues that the independent outlook of the artisan-become-salaried employee, was an important factor in the incipient development of industry as well as early attempts at labor organization. He argues that this "artisan outlook preserved the milieu of the artisan" until 
the end of the first World War. ${ }^{86}$ Actually, artisans continued to influence the the course of labor organization well into the 1920's and 1930's. Associations of cobblers and tailors, for example, collaborated closely with textile and construction workers to protest working conditions, unemployment among their ranks, and poor wages during labor unrest in Barranquilla in 1928-1929, and the cobblers union was among Barranquilla's first two unions to receive legal status in 1937.87 Not until the post-war period of rapid socioeconomic changes that would transform Colombia in the 1930's and 40's, was a predominantly wage-earning class gradually to emerge.

${ }^{86}$ Victor Alba, Politics and the Labor Movement in Latin America, (Stanford, California: Stanford University Press, 1968), p.20.

${ }^{87}$ Cesar Mendoza. Ramos, Surgimiento y Desarrollo de la Clase Obrera en Barranquilla, Paper presented at the 3rd Congress of Colombian History, Universidad de Antioquia, Medellin, Colombia, (November, 1981), p. 11 . 


\section{CHAPTER 5}

\section{VICTORY IN DEFEAT: CONSOLIDATION OF THE LIBERAL EXPORT ECONOMY}

"A mí se me iban escaseando (los peones en el trapiche), pero le mandé a picar el rancho a un arrendatario que se me estaba altivando, y temblando o no temblando, están todos obedientes. No hay cadena tan poderosa como la tierra...figúrese usted que les arrendáramos el aire, así como les arrendamos la tierra que les da el sustento icon cuánto mayor respeto nos mirarían estos animales!"

Discussion between two landlords in Colombian novelist Eugenio Diaz's 1866 work La Manuela ${ }^{1}$

"La pobreza no nos deja hacer nada y como no hay caminos, alli se perdería todo botado; y no sólo es eso, sino que los dueños de la tierra nos perseguirían. Es bueno con lo poco que alcanzamos a tener, a medio descuido ya nos están echando de la estancia, haciéndonos perder todo el trabajo, ¿qué sería si nos vieran con labranzas de añil, café y todo eso?"

Campesino's response to Bogotano Gólgota Radical don Demóstenes' query about why he plants export crops--from Colombian novelist Eugenio Diaz's 1866 novel La Manuela $^{2}$

"I know very well that an abyss stretches between Liberalism and Catholicism, the same abyss that exists between light and darkness, between truth and error; consequently, I declare myself to be Conservative, politically speaking, and I place myself at once at the service of the Christian Republic, and I offer my person in defense of the blue and white flag, sublime and alluring symbol of the great Conservative party"

Nineteen year-old Liberal prisoner's declaration that he is no longer a Liberal--in his efforts to obtain his release from the Panoptico prison. ${ }^{3}$

\section{MYTH OF THE "DEMOCRATIC FRONTIER": LABOR AND LAND IN THE COUNTRYSIDE}

In the middle of the nineteenth century, Colombia was still a nation of subsistence agriculture. The mid-century rise of the Liberal regime paralleled the gradual transformation of the agricultural economy from an inward, domestic orientation toward increased production of cash crops destined for export markets. As a result of a number of factors including the rugged, isolated geography of its major population centers, unlike many other colonies Colombia had developed a thriving agricultural base oriented toward

\footnotetext{
${ }^{1}$ Eugenio Diaz, La Manuela, (1866) p. 48, quoted in Kalmanovitz, Economia, p. 144.

${ }^{2}$ Eugenio Diaz, La Manuela, (1866) p. 79, quoted in Kalmanovitz, Economia, p. 145.

${ }^{3}$ Bergquist, Coffee, p. 169.
} 
meeting local demands. With the important exception of the gold, which was only mined in certain regions and required a limited workforce, Colombia early on was relatively isolated from the world economy. This was to change dramatically in the course of the latter half of the nineteenth century.

First tobacco and later its export successor coffee, would become the favored agricultural commodities for export to eager U.S. and European markets. Outside subsistence farming and small-scale production to meet local market demand for foodstuffs, agricultural workers laboring in the export agricultural sector comprised the largest single group of workers in the Colombian economy in the latter half of the nineteenth century.

Coffee played the major role in the formation of domestic capital in the last two decades of the nineteenth century and the first two decades of the twentieth. Given the overwhelming importance of coffee not only in making the accumulation of capital by Colombian capitalists possible, but also its key role in attracting the massive foreign investments in the 1920's that taken together fueled the incredible industrial growth of the 1930 's and 40's, those who worked in the sector merit serious attention in any treatment of the development of Colombian labor. As Bergquist argues in his studies of the Colombian coffee industry, without an understanding of this critical sector, one cannot hope to make sense of subsequent developments in labor organization ${ }^{4}$

As Bergquist correctly notes, small-time independent coffee producers and their sharecropping allies aspiring to ownership of their own lands came to rely on the Conservative or Liberal Parties to advance their individual and at times, their group interests, just as ultimately the majority of urban workers would come to do. He writes:

The Liberal and Conservative parties, it is true, governed the nation in the interest of large capitalists who dominated finance, production, and exchange in the Colombian coffee export economy. Government land, labor, and credit policies consistently favored the interests of large coffee producers and exporters...given the conditions of their labor, and the structure of their hopes for a better life, for many workers in coffee production the capitalist ideologies of the two traditional parties made sense. Both the ruling class and tens of thousands of working class people manipulated the party system to advantage. ${ }^{5}$

\footnotetext{
${ }^{4}$ Bergquist, Labor, p. 281.

${ }^{5}$ Bergquist, Labor, p. 278.
} 
That coffee transformed the Colombian economy and Colombian society itself cannot be denied. Its overarching impact was to insert Colombia permanently into the capitalist world economy. This was accomplished in part by linking the country to the international market through its reliance on coffee as the nation's major earner of foreign exchange. In addition, coffee's success as the primary export crop of the late 1800's and the early twentieth century permitted the accumulation of domestic capital in quantities that had never before been witnessed in the nation's history. In turn, this success attracted massive infusions of foreign loans and investments which helped fuel the importsubstitution industrialization of the 1930's. The success of these new industries would permit Colombia to supply domestic demands for a wide variety of products ranging from shoes and textiles to nationally-made machinery for the mining, domestic agriculture and coffee sectors.

In the countryside, labor underwent a rapid transformation occasioned by the rise of a predominantly export-oriented coffee economy by the 1880 's. Bergquist argues that these changes created special conditions that prevented the development of an independent labor movement in the countryside. He writes:

"The social relations of production in Colombia's unique agricultural export economy generated a Hobbesian system of cultural values, preserved an archaic and destructive political system, insured the viability of a peculiarly exploitative pattern of liberal capitalist economic growth, and subverted the formation of a powerful, class-conscious labor movement capable of finding a progressive solution to the problems of Colombian development...The influence of Colombia's coffee economy, considered as a unique set of evolving, contradictory class relations, can thus explain the peculiar features that distinguish modern Colombian development from historical patterns in the other major nations of Latin America." 6

Bergquist correctly asserts that the coffee economy which developed in Colombia helped to "subvert" the creation of an independent labor movement in the countryside and by its lack of organizational strength, contributed to the failures of organized labor in the transport and manufacturing sectors. After the marked decline in Colombian exports between 1800 and 1850 of more than 40 percent, the result of a combination of factors which included the devastation wrought by the war of independence, early government economic policies that discouraged exports, and a decline in precious metals exports, per capita exports recovered to increase more than 29 percent over the levels of 1800 by the end

${ }^{6}$ Bergquist, Labor, p. 276. 
of the century. ${ }^{7}$ Under the impetus of Liberal governments that encouraged the export of tobacco, cotton, dyes, leather and gold, Colombia pursued a staunch laissez-faire course up until the early 1880 's. Between 1850 and 1875 a tobacco boom, primarily taking root in the Magdalena Valley, led to export earnings of between two and three million gold pesos per year. ${ }^{8}$ Even after socially conservative Rafael Núñez's ascent to power, coffee exports would continue to rise up until the time of the Thousand Days War before demand declined, and again recover shortly after the turn of the century. By 1896, coffee exports were valued at over 10 million gold pesos, five times more than they had been a short ten years earlier. ${ }^{9}$

By 1875 , coffee and bananas had replaced tobacco, quinine, indigo and cotton as Colombia's chief exports. In response to the increased demand for these export crops in the industrializing nations, domestic banana plantations as well as foreign fruit enclaves, began to spring up in the hot wetlands of the Caribbean coast. Large scale entrepreneurs also began to cultivate coffee in Colombia's still largely-virgin temperate midlands. The initial economic success of a small number of large land owners soon encouraged others to enter the arena. The revolution in transportation in Colombia, the introduction of steam navigation on the Magdalena, the construction of new roads and the eventual establishment of rail travel, quickly led to the growth of small markets oriented to local consumption. These developments greatly facilitated the rapid frontier expansion witnessed during the second half of the nineteenth century.

One major obstacle that stood in the path of the development the great haciendas however, was the critical shortage of labor that existed in the principal areas of economic expansion. The major concentration of population in Colombia is in the highlands along the central cordillera. Therefore, in order to attract an adequate supply of labor, large landowners were forced to allow the tenant, or arrendatario, to grow crops on a small parcel of his land in return for rent, in the form of labor in the landlords' fields. This form of tenancy was common in the older coffee-growing regions of the central highlands,

\footnotetext{
${ }^{7}$ Figures according to Kalmanovitz, Economia, page 175 . See his graphic illustration of per capita Colombian exports based on Ocampo's studies at the top of page 176.

${ }^{8}$ Bergquist, Labor, p. 290.

${ }^{9}$ Bergquist, Labor, p. 293.
} 
western Cundinamarca and Tolima. ${ }^{10}$ In the coffee regions of Santander, Antioquia, and Caldas, aparceria or sharecropping was the prevalent form of tenancy. In addition, as Catherine LeGrand notes, "almost all large rural enterprises also employed some wage laborers for specific tasks: they were used on coffee estates at harvest time, on cattle ranches as cowboys, and on the United Fruit Company banana plantations where some settlers of public lands also contracted for a wage to work part-time in the banana groves." 11 Because of the chronic lack of a ready supply of labor, the rural worker had a certain amount of leverage he could exert over the large landowners, particularly in terms of the conditions under which he would agree to work.

Perhaps a greater source of power for the campesino however, was the widespread availability of national land, particularly in the frontier regions. The availability of this land also served to enhance the campesinos' position further by reducing the pool of labor. Even in Tolima and western Cundinamarca, once peasants contracted from the highlands through the enganche system managed to save enough to start their own farms, they generally abandoned their landowners' fields to move to public lands in the region. ${ }^{12}$

It has been estimated that the amount of land that remained a part of the public domain in Colombia in 1850 probably comprised about $75 \%$ of the entire Republic. ${ }^{13}$ Migrants, which included displaced artisans from the cities, peasants from the highlands, Indians, and a general exodus of political refugees fleeing the endemic civil wars of the nineteenth century, streamed to the frontier, attracted by the promise of free government land. Smallholdings of 10-30 hectares sprang up near rivers, roads, and railroads that could provide the colonizers with access to domestic markets. These smallholdings primarily produced beans, yucca, corn, and plantains but large amounts of wheat, sugar cane, rice, cacao, and some coffee to sell in local markets.

${ }^{10}$ Catherine LeGrand, "Labor Acquisition and Sociai Conflict on the Colombian Frontier, 1850-1936," Latin American Studies, (Vol. 16, 1985), p. 36. The best general descriptions of labor tenancy in the countryside are Bergquist's Coffee and Conflict in Colombia, 1886-1910 (Durham, N.C.: 1978), and the section on Colombia in his Labor in Latin America: Comparative Essays on Chile, Argentina, Venezuela, and Colombia (Stanford, Califomia: Stanford University Press, 1986), see especially pp. 313-318. Other important contributions include: Gloria Gaitán, La Lucha Por la Tierra en la Década del 30: Génesis de la Organización Sindical Campesina (Bogotá: El Ancora Editores, 1984); and William Paul McGreevey, An Economic History of Colombia (Cambridge, England: 1971).

${ }^{11}$ LeGrand, "Labor Acquisition," p. 37.

12LeGrand, "Labor Acquisition," p. 33.

${ }^{13}$ LeGrand, "Labor Acquisition," p. 29. 
Initially, the Colombian government encouraged the development of smallholdings by offering the promise of free land. LeGrand reasons that this was a logical manoeuvre since these smallholdings on public lands may have accounted for a majority of Colombia's foodstuffs in the late nineteenth century. ${ }^{14}$ Since the availability of public land served to exacerbate further the critically short supply of labor, the landlords' logical response, the enclosure, was quick and generally effective.

The late nineteenth and early twentieth centuries witnessed the large-scale alienation of public lands, the vast majority ending up concentrated in the hands of wealthy landowners. In this period, more than 3.2 million hectares were officially alienated, while perhaps an even greater amount of land colonized by smallholders was obtained through illegal means such as coercion and brute force. ${ }^{15}$ The overwhelming majority of land was not virgin land but rather land occupied by peasant settlers.

Such facts help to shed light on the common, mythical belief in Colombia's pioneering democratic smallholder civilization in the west. In his major work on the Colombian labor movement, Bergquist argues convincingly that while land ownership was fairly widespread, the majority of smallholdings were only just large enough to be productive: in lean years, owners of small properties willingly submitted themselves and their families to ever-greater degrees of self-exploitation in order to maintain their status as independent producers. ${ }^{16}$ Even the fabled poblaciones of Antioquia received less than ten

${ }^{14}$ LeGrand, "Lábor Acquisition," p. 32.

${ }^{15}$ LeGrand, "Labor Acquisition," p. 34.

${ }^{16}$ Bergquist forcefully argues that this issue has been purposely obfuscated by both the conservative National Federation of Coffee Growers as well as leftist scholars, in both cases for ideological reasons. Census takers from the National Federation of Coffee Growers chose to look at the number of farms while ignoring the structure and tenancy of ownership. See Labor, pp. 298-304 for his thorough review of the coffee censuses of 1932, 1939 and 1955. He concludes that ownership in the first half of the century was indeed widespread, especially in the more recently settled coffee producing regions such as Antioquia and Caldas, and also, since between 1932 and 1955 the greatest expansion in the number of coffee producing farms actually occurred in Cundinamarca and Tolima, in these older areas that had the largest concentration of big coffee farms in 1932. (p.301). Since a viable size for a coffee farm ranges from 5,000 - 20,000 trees (2-8 hectares) depending on soil, age of trees etc., a majority of the farms in Colombia during this period were probably owner-operated family farms. (303). As a result of widespread ownership, much of the capital generated by the industry remained in Colombia, creating local demand for clothing, educational services and machinery used in the coffee industry. On the other hand, as a result of coffee growers' desire to maintain their land, they and their families have been subjected to deplorable living conditions in the coffee zones, as a result of the willingness to subject themselves to everincreasing degrees of self-exploitation. Extremely poor health care in the heart of the coffee producing region led to high levels of disease, higher than national averages of infant mortality, birth rates and death rates, high incidences of malaria, yellow-fever, and other diseases throughout the first half of the twentieth century. Bergquist's extensive first-hand experience in the coffee zones adds realism to his 
percent of the territory that had been made available for colonists: more than 70 percent of the total land was granted to properties greater than 1,000 hectares in size. ${ }^{17}$

Enclosure was an effective tactic to ensure an adequate supply of labor for the landowners' fields. It was also however, a major source of conflict between landlord and peasant during the rest of the century, as well as a recurring problem throughout the twentieth century. During this period, smallholders were forced to sign unfavorable tenancy contracts or to vacate their lands.

In an effort to slow the pace of the expropriations, Congress passed legislation in 1874 and 1882 which was interpreted by many smallholders as a vindication of their rights to the land. ${ }^{18}$ The laws implied that rightful title to land should in most cases go to those who were working it. Therefore, the settlers began to resist the enclosures with varying degrees of success. Many banded together and hired lawyers who often fought successfully for their claims in court. Others organized defense groups that also frequently enabled peasants to retain their lands. Nevertheless, as previously indicated, many of the smallholdings ended up in the hands of large estate owners who continued to employ hacienda methods of labor recruitment. Generally, through strategies such as using their political connections, or palanca, the large landowners could have settlers' titles declared illegal, have local alcaldes evict the "squatters," could deny smallholders access to water and roads, would sometimes set cattle onto their fields and at times, through physical violence could force smallholders to abandon their lands or sign tenancy contracts. ${ }^{19}$ Once a tenancy contract was signed, the landowner had another piece of evidence the hacendado could use to legally claim the once-pulic, formerly colonist's land.

Nevertheless, as mentioned above the large landowners were not always successful in their efforts to increase their landholdings and recruit labor. In common with artisan

discussion of these problems and daily life in the coffee-producing regions. But land ownership was central to every smallholder. Bergquist writes: "Possession of a freehold, the bigger the better, was the goal of every coffee worker. That aspiration is often dismissed in Marxist and liberal scholarship as an anachronistic, irrational impulse inherited...by peasants from precapitalist social formations. It is true that as petty commodity producers, Colombian coffee smallholders were swimming against the tide of history...[But] it is also to fail to recognize that their struggle was but a specific expression of goals shared by all workers in all societies: the desire to control one's own life, to decide how and when work is done, and to appropriate the full value of one's labor." (p. 325) See Bergquist's description of coffee production, pp. 318-330, Labor in Latin America.

${ }^{17}$ LeGrand "Labor Acquisition," culled the list of government land grants for the years 1821-1931 to unearth this information, p. 34.

${ }^{18}$ LeGrand, "Labor Acquisition," p. 37.

${ }^{19}$ LeGrand, "Labor Acquisition," p. 39. 
workers in the cities, an overwhelming majority of smallholders looked to the traditional parties to enhance their claims to land. Often colono claims would be upheld, especially if they were brought against a large landowner of the party not in power at the moment. Despite national legislation favorable to colono claims passed in 1872 and 1882, the overwhelming majority of land disputes were resolved at the local level, at times in favor of the colono's claims. ${ }^{20}$ Bergquist notes that, "even at the level of veredas, the subdivisions of Colombian municipios (counties), smallholders or sharecroppers of one political affiliatation might enlist the support of local urban politicians and lawyers in their resistance to large landowners-or to other smallholders-of opposite political loyalties." 21.

Colonos, settlers and sharecroppers shared a similar outlook in terms of ownership of the means of production and a strong desire to secure or retain control of their labor power with the independent artisans in Colombia's towns and cities. Like the artisans, some of who made up the waves of migrants looking to Colombia's western frontier for expanded horizons for themselves and their families in the last half of the nineteenth and the first half of the twentieth centuries, with few exceptions, the colonos and sharecroppers looked to one or the other of the traditional parties to improve their lot in life. Like the artisans, this partisan strategy was only partially successful. Some individuals benefitted by receiving land and party favors. However, as in the case of the artisans, this reliance on élite-led Liberal and Conservative Parties also had the effect of undermining efforts at collective action as well as subverted the development of a potential consciousness of campesinos as a class with interests clearly apart from those advocated by the traditional parties. At the same time, mainstream party ideologies strengthened sentiments of individualism commonly ascribed to Colombian agricultural workers, making organization along communal lines difficult at best, as the communists were to discover in their largely unsuccessful organizing campaigns of the 1920's.

\footnotetext{
${ }^{20}$ The fact that most disputes involved rival claims between poor colonos or between individual colonos and landowners in a limited geographic area, it makes a great deal of sense that the majority of disputes would be resolved at the local level. Given the highly diffuse power structure in an extremely federalist Colombia at the end of the nineteenth century (Rafael Nuñez's reforms to strengthen the central government in the 1880's would take years to show changes in local power structures and systems of clientelism) and the concomitant weakness of the central government, the lack of central government intervention in resolving legal disputes before the 1930's provides an additional reason why even large disputes involving several colonos were generally resolved at the local level.
}

${ }^{21}$ Bergquist, Labor, p. 292. 


\section{THE RISE OF THE EXPORT ECONOMY: TOBACCO AND COFFEE}

Rapidly expanding investments in coffee had a pronounced effect on not only the economic growth of Colombia, but as Bergquist has argued persuasively in Coffee and Conflict in Colombia, also had important ramifications in the political strength of export interests in their incessant struggles with the generally conservative large landowners for the control and direction of government trade policy, as well as over issues such as federalism and the power of the central government.

The following table illustrates the expansion of tobacco in the nineteenth century and of coffee exports in the late nineteenth and early twentieth century.

TABLE 5:1

Coffee and Tobacco Exports (Thousands of Pesos)

\begin{tabular}{lrr}
\hline Period & Tobacco & Coffee \\
\hline $1843-1844$ & 159 & n.d. \\
$1855-1859$ & 1,924 & 338 \\
$1866-1869$ & 2,726 & 774 \\
$1870-1874$ & 2,031 & 785 \\
$1875-1879$ & & 1,142 \\
$1895-1899$ & & 4,000 \\
$1906-1909$ & & 5,841 \\
$1910-1914$ & & 13,247 \\
$1915-1919$ & & 24,379 \\
$1920-1924$ & & 45,689 \\
& & \\
\hline
\end{tabular}

Source: Kalmanovitz, Economía y Nación, Table 3.4 , p. 210 .

During tobacco's heyday between 1866 and 1869, exports fetched more that two and one-half million pesos. After the precipitous decline of tobacco exports during the late 1870 's and early 1880 's, a product would not be found that could effectively fill the vacuum created by the increased competition from the far east and a decline in leaf quality. Coffee would not begin to fill that export gap until a decade later. By 1895-1899 however, the export value of coffee was about twice that which tobacco had been in 1870-1874, and twenty short years after the turn of the century, more than twelve times greater. ${ }^{22}$

\footnotetext{
${ }^{22}$ Kalmanovitz, Economia, p. 210.
} 
Liberal governments encouraged the export of other items, particularly after the bottom fell out of the tobacco market after 1870. Such goods included gold, sugar cane, cacao, cinchona bark, cotton, leather, and indigo. ${ }^{23}$

In order to facilitate the expanding export-import trade, the transportation infrastructure, which in 1840 remained inadequate, had to be greatly improved. After 1840 , the year permanent steam navigation was introduced on the Magdalena, transportation costs plummeted. Sowell reports that steam transportation costs had decreased by as much as one-half by $1860 .{ }^{24}$ The federal government provided funding for many transportation projects including roads and railways in various parts of the nation, when they were deemed necessary to serve the export-import trade, in the 1860's and 70's. Only the most important transportation projects were begun however because of a lack of capital and other factors, and many were not completed during this period.

As early as 1880 rapid economic changes brought about by the expansion of the coffee industry began making themselves felt throughout Colombia. The social theorist, economist-politician Anibal Galindo wrote in 1880:

The characteristic phases of this economic revolution are three in number: (1) the access of all classes -down to the very lowest- to the goods and comforts of wealth through the extraordinary growth of production and through the extreme inexpensiveness of products made with the assistance of these automatons who work for infinitely small salaries. Photography, oleography, telegraphy, lithography, printing; the sewing machine and machines for spinning and weaving cotton have made comfort, pleasures, and benefits available to the lowest social classes that were previously the privileges of the land's potentates; (2) the decreasing use of manual labor, and replacement of the beast-of-burden role imposed on the worker by the intellectual and moral work of supervision and vigilance to which the functions of the worker in the modern workshops are being reduced. On all side, mutatis mutandi, the porter moves into the category of the railroad guard or watchman; and (3) the migration to great population centers in the search for work and salary levels available in the world market owing to the rapidity, the facility, and the economy with which trips may be made by modern means of transportation 25

${ }^{23}$ Utilizing statistics that had been gathered from various sources including William McGreevey and Jorge Rodriguez, Nieto Arteta and Miguel Unutia, and Gerardo Arrubla. William Park Rafael Nuñez, has compiled information on the respective values of Colombia's most important exports as well as other trends in the export of the most important products during this period, tobacco, cinchona and coffee, as well as other more minor, but important commodities. See pp. 60-64.

${ }^{24}$ Sowell, "The Early Latin American Labor Movement," p. 20.

25 Orlando Fals Borda, Subversion and Social Change in Colombia (New York, 1969), p. 120. 
By the late 1800 's, the large banana and sugar plantations had also been firmly established. Incipient industrial activities could also be witnessed in many parts of the country by the turn of the century.

\section{RAFAEL NÚÑEZ AND THE RISE OF SOCIAL CONSERVATIVISM}

With the election of Rafael Núñez as the new Liberal president in 1880, the conservative wing of the Liberal Party, the Independent Liberals passed a protective tariff and a created a National Bank in an effort to stimulate economic growth. Bergquist notes that the Radical Liberals had begun a rapprochement with the Conservatives and the Church.in 1878 by supporting a moderate candidate, Julian Trujillo. ${ }^{26}$ But with the ascent of Núñez, Colombian politics were to change profoundly. A life-long Liberal from Cartagena, socially Núñez was a conservative who sought to heal the chasm between his party and the Catholic Church as well as reverse the party's longstanding commitment to extreme federalism. Núñez even received the Conservative Party's endorsement in 1884 as well as their loyalty when Radical Liberals opposed to his wide-ranging reforms staged an unsuccessful revolution in 1885. The Independent Liberals and Conservatives joined together in a new alliance and created the Nationalist Party.

Socially and politically conservative, this alliance dominated Colombian politics throughout the period known as the Regeneration. Bergquist describes the ideological orientation of the Nationalists in the following manner:

Lacking strong ties with the liberal community of the West, these Conservatives found their intellectual nourishment in Catholic and Spanish thought. Nationalist Conservatives viewed society as a hierarchy of men with different capabilities and functions. Strong institutions such as the family, the Church, and the State were needed to control men susceptible to evil passions and anti-social behavior unless instilled with a moral code capable of uniting men on a spiritual level...Satisfied with their position in life and aloof from foreign critics, Nationalist Conservatives felt no shame for the 'backwardness' of the country. unlike their Liberal opponents they found virtue in [Colombia's] Spanish heritage, its Catholic purity, and the intellectual and literary achievements of its elite." 27

Except for a continued reliance on an expanding coffee industry to help fuel domestic growth through exports, Núñez abandoned the laissez-faire economic policies of the Radicals while adopting a more interventionist stance. In terms of economic policy, he

\footnotetext{
${ }^{26}$ Bergquist, Coffee, p. 14.

${ }^{27}$ Bergquist, Coffee, p. 16.
} 
also argued that the central government should take a more active role in improving the general conditions of the nation's people. Unlike during the period of extreme laissez-faire economics in the 1850's, 60 's and 70's, Núñez favored moderate protection of national industries, as we have discussed in some detail in Chapter Four. Artisans benefitted from mildly protectionist tariff policies for key industries, as well as through the creation of a number of federally and locally-funded trades schools. ${ }^{28}$

Many of Núñez's reforms were vigorously opposed by the Radical Liberals. As mentioned earlier, the newly created National Bank emitted a fixed supply of paper money which initially stimulated coffee expansion. But when emissions were too great, as in the 1890 's, stimulated even stauncher resistance by the Liberals by destablizing the economy. Another issue that drove a wedge between Núñez and his former party, although not as divisive as it had been earlier in the century before the problems experienced in the 1860's and 70 's, was the issue of federalism verses. centralism. In general, Liberals sought greater decision-making power for the departments, while the Nationalist Conservatives favored a strong central government. Another reform strongly opposed by Liberals was the Constitution of 1886 which restored the Church's privileged place in Colombian society. Along with the issue of paper money, it became one of the major issues separating the Conservatives and Liberals during the decade.

In 1891, Núñez was again elected President, though Vice President Miguel Antonio Caro would actually serve as the head of the nation. ${ }^{29}$ Although the Conservatives split, Marceliano Vélez running a parallel campaign with Jose Joaquín Ortiz, the Liberals decided to continue the policy of abstention they had adopted after their failed bid to gain power through force in 1885. Despite the support of the moderate 'Historical Conservatives', a group of moderates whose center of strength lay in Antioquia, the abstention of the Liberals ensured another conservative Nationalist government. ${ }^{30}$ Caro's, authoritarian style probably helped split the Conservative Party although Bergquist argues that the main reason was an ideological rift between the "Historical Conservatives" who opposed tariffs on coffee exports and the "Nationalist Conservatives" who supported them. Of Caro,

${ }^{28}$ Sowell, "The Early Latin American Labor Movement," p. 331.

${ }^{29}$ Núnez retired to his home in Cartagena, and did not actively serve during his final term.

${ }^{30}$ For the best historical account of this period, see Bergquist's Coffee and Conflict in Colombia. Helen Delpar's Red Against Blue, The Liberal Party in Colombian Politics 1863-1899 (Alabama: The University of Alabama Press, 1981) also provides a good account of the unfolding of events during this period from a political perspective. 
Bergquist writes "In contrast to Núñez's philosophical eclecticism and political flexibility (his critics would say opportunism), Miguel Antonio Caro's life and thought reveal a remarkable consistency, an organic unity. Translator of Virgil, apologist for the Spanish legacy in America, renowned philologist and literary critic, militant Catholic polemicist, and Conservative political and economic philosopher, Caro approached every problem deductively, reasoning from a set of basic Catholic, conservative values: order, hierarchy, cultural unity. ${ }^{31}$ Caro, who notes Park, was from an élite family and received his education in the Jesuit Colegio de San Bartolomé in Bogotá."never left the highlands surrounding Bogotá." Consonant with Bergquist's assessment, Park adds "whereas Núñez was worldly, flexible, possessed of a wide-ranging intellect, and capable of arousing a loyal following through the force of his personality, Caro was insular, doctrinaire, limited in vision, devout, and scholarly. He would compromise only under extreme pressure by which point the political benefits of compromise were largely mitigated." 32

The Liberal Party chiefs decided that it was time to begin reorganizing publicly by 1893, though they also clandestinely prepared for war against the government. The Conservatives reacted swiftly, arresting the Liberal leadership, shutting down the new Liberal newspapers, and confiscating the party's treasury. ${ }^{33}$

Relations between the Liberals and the government continued to sour, curbs placed on the press and the infamous Law of the Horses, a series of laws curbing civil liberties, making it illegal for example to publish articles criticizing the conservative government. Relations with the artisans also declined after the 1893 bread riot which the government violently suppressed killing 40-45 and arresting hundreds more. The Liberals rebelled in 1895, receiving much support, though unofficial, from the Historical Conservatives.

Liberals again went to war in 1899 , this time well organized and prepared to fight until the Nationalist Conservatives were driven from power.

\section{WAR OF A THOUSAND DAYS AND THE PANAMA CRISIS}

Finally, the Liberals decided to act in 1899, launching the most destructive of all of the civil wars of the nineteenth century, the War of a Thousand Days. Historical

\footnotetext{
${ }^{31}$ Bergquist, Coffee, p. 43.

32Park, Rafael Nuñez, p. 276.

${ }^{33}$ Bergquist, Coffee, pp. 154-55.
} 
Conservatives had managed to have their candidate Jose Manuel Marroquín, a moderate elected as president. Unfortunately for the Historical Conservatives, the Liberals and the tens of thousands of Colombians who would die in the Thousand Day War, as a result of the president's poor health, the government fell into the hands of Aristides Fernández, director of the police in Bogotá and one time governor of Cundinamarca, who assumed power under the banner "acabar con los liberales, esos bandoleros". ${ }^{34}$

With the presidential election of 1897 , the Historical Conservatives had hoped to implement their reformist program. Bergquist argues that "by the end of the century these upper class factions were deeply divided along an axis of ties, or lack of them, to the evolving capitalist system of the North Atlantic. Import-export interests, voicing their demands through the Liberal and Historical Conservative parties, found their inspiration in North Atlantic political liberalism and laissez-faire economics. Involved in international trade and domestic finance they sought a return to the gold standard, lower tariffs, abolition of government monopolies and export taxes, and proper attention to the foreign debt."35 The Nationalist Conservatives were not involved in export-import activities and they "based their policies on principles derived from conservative Spanish and Catholic thought." "Nationalists," Berquist continues, "represented bureaucratic, ecclesiastical, and apparently (although the evidence is largely circumstantial) traditional agricultural interests who benefited from the statist economic policies and centralist, pro-Catholic political policies of the Regeneration governments." 36

The Thousand Days War became one of the bloodiest, some experts claim the bloodiest civil war of the nineteenth century in this hemisphere, leading to the death of tens of thousands, ${ }^{37}$ and causing major loss of property and catastrophic economic dislocations, particularly to roads, railways and the communications network. Uribe Uribe signed the Treaty of Neerlandia in 1902, and General Benjamín Herrera later drew the war to a close in the isthmus by signing the Treaty of Wisconsin in late November of the same year on the U.S. Warship Wisconsin off Colombia's Panamanian coast. Colombianist Robert Dix

${ }^{34}$ Molina, Las Ideas Socialistas en Colombia, p. 177.

${ }^{35}$ Bergquist, Coffee, p. 51 .

${ }^{36}$ Bergquist, Coffee, p. 51.

${ }^{37}$ The generally accepted estimate is 100,000 deaths. See McGreevey's interesting discussion of the origin of this figure in his article "Reinterpreting Colombian Economic History," Journal of Interamerican Studies and World Affairs, Vol 23 No. 3 (August 1981). 
argues that one reason the warring parties decided to make Peace after more than three years of fighting is that élite factions from each began to feei that they were losing control over the conflict. He writes, "There is likewise some evidence that the war of 1899-1902 had begun to take on faint overtones of class revolution in the countryside. Although the matter bears further investigation, if true, this would be an additional inducement for the elite groups that controlled the two parties to make peace in order to stem the threat to themselves from below." 38 As in 1854, in response to a potential challenge to its class hegemony from the laboring classes, the leadership of both parties found inter-élite cooperation preferable to a loss of "los oligarcos'" dominant position in society.

Probably the most traumatic outcome of the conflict however was the physical separation of Panama in 1903 after an uprising in the isthmus. The United States, which had been supporting the rebels in an effort to get a more favorable treaty permitting it to build and control an interoceanic canal than the one it had been negotiating with Colombia, had sent a fleet to prevent Colombia from reinforcing its garrisons in the isthmus. The U.S.'s intervention guaranteed the success of the rebellion: after reeling from the initial shock, élites from both parties decided that cooperation between them was preferable to further dismemberment of the nation.

\section{CONCLUSION: CONSOLIDATION OF THE LIBERAL EXPORT ECONOMY}

The Colombian coffee bonanza of the late nineteenth and early twentieth centuries had several important consequences for labor. First, the rise of coffee and the simultaneous opening of the western frontier drew countless thousands of migrants from the nation's central highlands in search of virgin lands in mid-and low altitudes to stake their claims. Thousands, perhaps as many as tens of thousands of smallholders in the coffee zones of Cundinamarca and Tolima were impoverished farmers who worked properties with fewer than 5,000 trees during the 1930 's, 40 's, and 50 's many forced to work on local latifundi to make ends meet. ${ }^{39}$ Many of these were willing to submit themselves and their families to ever-increasing levels of self-exploitation to enable them to overcome difficult times in order to maintain their properties. Many of the migrants were converted into sharecroppers and tenants. Others were driven forcibly from their claims

\footnotetext{
${ }^{38}$ Robert Dix, The Politics of Colombia (New York: Praeger Publishers, 1987), p. 25.

${ }^{39}$ Bergquist, Labor, p. 300.
} 
through illegal enclosures affected by hacendados. Many thousands more successfully acquired properties. ${ }^{40}$ Of course even the successful colonists who had struggled intensely to maintain their claims, watched their hard-earned property fragment between their offspring through inheritance.

In terms of national economic development, the widespread ownership of coffee production had positive benefits, creating internal demand for products ranging from domestic-made coffee de-hulking machines to the clothes and domestically-produced sandals worn by most Colombian peasants. The expansion of coffee also, as explained above, permitted the large scale accumulation of domestic capital and the attraction of additional foreign capital to help fuel industrial development, and the creation of an urban working class.

And finally, smallholders who also wished to cash in on the expansion of an agricultural export economy based on coffee turned to the traditional parties to advance their claims. Bergquist correctly assesses this impact on their long-term interests when he writes, "Capitalist exploitation in Colombia, especially in the coffee export sector, more often reinforced conservative individualist values and institutions than it fostered radical, collective ones; more often solidified the social and political status quo than it threatened progressively to transform it." 41 For the overwhelming majority of laborers in the countryside, the strategy of playing partisan politics, as in the case of their urban, artisan counterparts, this strategy of allying themselves with the Liberal or Conservative Parties, undermined rural workers' solidarity, prevented the formation of class consciousness, and ultimately led to the subservience of their interests to those of the ruling élite.

A consensus had developed among the Colombian oligarchy that the strategy of export-oriented, specifically coffee-led export-oriented growth, was the key to national economic development. One reason for the consensus was the fact that exporting was much less a Liberal activity than it had been in the mid-nineteenth century. By the turn of the century, the "agricultural export economy had become bipartisan, having expanded from Liberal domains in eastern Colombia to encompass the traditionally Conservative domains of the Antioqueños. Colombian coffee was grown largely on small and mediumsize farms, thus providing a wide base of support and legitimacy for the post-1902 political

\footnotetext{
40The 1955 FAO/ECLA survey of coffee farms in Colombia showed that 78 percent of farms ranging from 1.1 to 10 hectares were owned by their operators, showing that "land ownership was very widespread in Colombian coffee production and that small family farms made up the most numerous and important unit of Colombian coffee production." Bergquist, Labor, pp. 302-303.

${ }^{41}$ Bergquist, Labor, p. 279.
} 
order as well as affording a channel for enterprise and upward mobility outside the bounds of violence-prone clientelist politics." 42 Referring to the War of a Thousand Days, Bergquist aptly summarizes: "if the Liberal and Historical Conservative factions tied to the export-import economy lost the war, they were to win the peace...After the secession of Panama bolstered the political fortunes of bipartisan export-import interests by fostering a consensus among Colombian leaders that the nation must unite politically and develop itself materially if it were to avoid further dismemberment." 43

The War of a Thousand Days had demonstrated to both party's leadership ranks the depth of destruction such an internecine struggle could reek among the ruling élite. Bergquist notes that the war "left in its wake unprecedented human and economic destruction, monetary chaos, the incipient collapse of élite social control...Coffee ushered in a new era of ruling-class consensus, political stability, and export-oriented development...But coffee did not transform the political system Colombians inherited from the nineteenth century. Rather, it reinforced its socially most destructive features." 44 Robert Dix agrees with this assessment, noting that the nation emerged from the nineteenth century with a functioning Congress and electoral process, but a rather paradoxical tendency to resolve political disagreements through violence. ${ }^{45}$ Also, with the rejection of Reyes' extralegal usurpation of power after completing his term as president, Colombians strengthened their tradition of rejecting dictatorships, showing an ideological preference for "legitimate government" by a ruling class rather than by an autocratic individual.

Although the élites rejected Reyes when he attempted to extend his presidency for ten years, initially he had been embraced by Liberals and Conservatives alike as a moderate. Although he imposed a tariff in 1905 to help stimulate industrial growth, he had made his fortune in international trade, and did much to eliminate differences between partisans of the two traditional parties. ${ }^{46}$ Moreover, his overtures to the Liberal Party by including Liberals in his cabinet went a long way toward healing the wounds caused by a

\footnotetext{
${ }^{42}$ Bergquist, Coffee, p. 236.

${ }^{43}$ Bergquist, Coffee, pp. 195-96.

${ }^{44}$ Bergquist, Coffee, p. 294.

${ }^{45}$ Dix, The Politics of Colombia, p. 124.

${ }^{46}$ Sowell, "The Early Latin American Labor Movement," p. 33. The tariffs imposed by his administration helped stimulate industrial growth in the capital, but particularly benefitted incipient manufacturing in Antioquia.
} 
long war that had proven disastrous to both sides. The Constitution of 1910 went even further by guaranteeing that at least $1 / 3$ of the seats in Congress would be held by the minority party, inaugurating a period of compromise and consensus among ruling class élites. "Los oligarcos" had finally decided that in terms of ideological issues dividing the two major parties, "civil" disagreements could best be resolved within the context of an élite-dominated, Republican system.

Reyes' presidency heralded the beginning of a 45 year peace that has been dubbed the "classic period of Colombian democracy." 47 Mutual interest in supporting the coffee export industry had developed, consolidating the political hegemony of bipartisan exportimport interests. "By 1910," writes Bergquist, "a basic ideological and programmatic consensus had developed between dominant élites in both parties... and greatly contributed to the political legitimacy and stability of the new order." 48

Peace between the two traditional parties marked the next forty-five years. Colombia was one of only three nations in Latin America in the early 1930's in which civilians controlled the government. ${ }^{49}$ A Republican, as the coalition dominated by Historical Conservatives and also comprised of moderate Liberals were called, was elected to the presidency after the ouster of Reyes in 1910. It was also a coalition government dominated by Liberals, but also comprised of moderate Conservatives, that brought the government of the old Liberal Republican Olaya Herrera to the presidency in 1930 under the political banner of National Concentration. Herrera continued the process of élite compromise begun by Reyes by naming a bipartisan cabinet.

A challenge to this Conservative-Liberal accommodation would not come from the right, nor from the radical left, nor even from a united labor movement. Instead, in the late 1920 's and early 1930's, a new group of disaffected young Liberals, "Los Nuevos," influenced by utopian socialism, and heir to the "welfare Liberalism" embodied in the thought of Uribe Uribe a generation earlier, would passionately confront "los oligarcos."

${ }^{47}$ Dix, The Politics of Colombia, p. 25, includes the Reyes Quinquenio as part of this period since Reyes' bid to extend his term was unsuccessful.

${ }^{48}$ Bergquist, Coffee, p. 248.

${ }^{49} \mathrm{Costa}$ Rica and Uruguay were the other two nations that maintained civilian-controlled governments in the early 1930's. Sloan, "Regionalism, Political Parties, and Public Policy in Colombia," InterAmerican Economic Affairs, 33:3, (1979), p. 25. 


\section{CHAPTER 6}

\section{EARLY INDUSTRIAL GROWTH AND THE EMERGENCE OF A PROLETARIAT}

In times past it was the Cross or the Koran, the sword or the book that accomplished the conquests of civilization; today it is the powerful locomotive, flying over the shining rail, breathing like a volcano, that awakens peoples to progress, well-being and liberty... and those who do not conform to that progress it crushes beneath its wheels.

General Rafael Reyes, Address to the Second Pan American Conference in Mexico Cityl

La Asamblea de la Confederación Obrera de Bogotá, a nombre de sus electores y en vista de las necesidades del proletariado de Colombia, y considerando que el país atraviesa una crisis de descomposición política, económica y fiscal; que la miseria y la ignorancia vienen azotando desde muchos años principalmente a los labriegos y a las clases obreras de ambos sexos, y que los males apuntados redundan en perjuicio vergonzoso del país a la vez que en beneficio de determindadas clases privilegiadas...nos dice todo esto que ha llegado la hora de dar el grito de 'sálvese quien pueda'.

From the Preamble to the Socialist Platform, 20 May $1919^{2}$

\section{INTRODUCTION}

During the government of General Rafael Reyes (1904-1909), known as the Quinquenio, many of the large companies that are still active today initiated their operations. ${ }^{3}$ Rapid demographic growth accompanied these economic changes, the nation's population already topping six million by 1918 . During the Quinquenio coffee production diversified away from the eastern cordillera comprised of Santander and Cundinamarca to expand to the central cordillera--Antioquia, Tolima and northern Cauca. A flourish of construction on the nation's communication infrastructure to serve the expanding export economy included roads, mule trails and railroads. The number of kilometers of railway track doubled during Reyes' presidency and there were also notable

${ }^{1}$ Quoted in Bergquist, Coffee, p. 221.

${ }^{2}$ Reproduced in its entirety in Molina, Ideas Socialistas en Colombia, pp. 213-219.

${ }^{3}$ For a list of Colombian companies established during this period which continue to exist today, see Fals Borda, Subversion and Social Change, p. 120. 
improvements in steamship travel. ${ }^{4}$ Approximately 80 percent of the cargo moved by the Antioquia Railway was to service the coffee trade. ${ }^{5}$

It was not until the economic boom of the 1920's and 1930's however, that the modern socio-economic development of Colombia clearly took root. In 1918, the Nationalist Conservative Marco Fidel Suárez, who named a bipartisan cabinet, followed a policy of improving relations with the United States under his "Polar Star" foreign policy. Under Suárez and his successors, Pedro Nel Ospina (1922-26) and Miguel Abadía Méndez (1926-30), who continued the economic orientation towards the U.S., Colombia attracted major foreign investments. ${ }^{6}$

During Ospina's presidency in 1921, E.W. Kemmerer, an economics professor from Princeton along with a group of expert consultants, made a series of recommendations that were ultimately adopted by the government. Congressional action led to the establishment of a national bank, a bank extending agricultural credits, a mortgage bank, and the construction of a pipeline for large scale oil production. ${ }^{7}$ Foreign, particularly U.S. capital, led by the $\$ 25$ million indemnification between 1920-1921 for the U.S. role in the separation of Panama, flooded the country. ${ }^{8}$

Between 1925 and 1929 the per capita GDP grew at an annual rate of 5.2 percent, while industrial production grew by nearly 20 percent over the same period. ${ }^{9}$ Fals Borda paints a dramatic picture of some of the innovations that affected the Colombian economy between the years 1919 and 1933: "The Sociedad Colombo-Alemana de Transportes Aereos (SCADTA) began operations in 1919; its subsequent conversion into AVIANCA airlines had great positive effects on the bourgeois economy as well as on the processes of regional and national integration. The number of telephone lines increased from 5, 095 in 1913 to 34,680 in 1927." 10 The volume of mail multiplied by four times during the same

${ }^{4}$ Bergquist, Coffee, p. 236.

${ }^{5}$ Molina, Las Ideas Socialistas, p. 190.

${ }^{6}$ Bergquist, Coffee, p. 257.

${ }^{7}$ Fluharty, Dance of the Millions, p. 31.

${ }^{8}$ Fluharty, Dance of the Millions, p. 32.

${ }^{9}$ Fals Borda, Subversion and Social Change, p. 124 for the former figure, see Bergquist, Labor, p. 306 for the percentage growth of industrial production.

${ }^{10}$ Fals Borda, Subversion and Social Change, p. 124. 
period (Fluharty 1957, 16) and by 1929 there were already 15,350 automobiles in the country. ${ }^{11}$ Between 1930 and 1933, 842 enterprises were established, including all the present basic Colombian industries. Public services, transportation, electric power and the gross product of industries increased at annual rates between $7.8 \%$ and $9.1 \%$ through 1953.12 The following table illustrates the industrial growth for the years 1925-1953.

TABLE 6:1

Average Annual Rates of Increase of Industrial Production, 1925 - 1953

\begin{tabular}{cc}
\hline Years & $\%$ \\
$1925 / 29-30 / 34$ & 3.8 \\
$1930 / 34-35 / 39$ & 10.8 \\
$1935 / 39-40 / 44$ & 7.9 \\
$1940 / 44-45 / 49$ & 8.1 \\
$1945 / 49-50 / 53$ & 9.4 \\
\hline
\end{tabular}

Source: Richard Maullín, p.18.

Note that even during the lean years of the world-wide depression, industry posted rather remarkable growth, particularly during the zenith of the depression, 1930-39 when rates of.increase of industrial production averaged more than ten percent annually. A brief comparison of growth in Colombian manufacturing with other major Latin American nations, shows that during this period, industrial growth in Colombia actually outpaced that of the rest of Latin America. The following table relays Díaz Alejandro's findings on percentage growth of industrial growth.

${ }^{11}$ Fluharty, Dance of the Millions, p. 16.

${ }^{12}$ Fals Borda, Subversion and Social Change, p.124. 


\section{TABLE 6:2}

Average Annual Percentage Growth in the Value of Manufacturing Production, 1929-1949

\begin{tabular}{lcc}
\hline Country & $\mathbf{1 9 2 9 - 3 9}$ & $\mathbf{1 9 3 9 - 4 9}$ \\
\hline Argentina & 3.1 & 3.5 \\
Brazil & 5.0 & 7.2 \\
Chile & 3.3 & 4.8 \\
Colombia & $\mathbf{8 . 8}$ & $\mathbf{6 . 7}$ \\
Mexico & 4.3 & 7.5 \\
\hline
\end{tabular}

Source: Data originally taken from Díaz Alejandro,

"Algunas notas" from Bergquist, Labor, p. 309.

Coffee exports also continued to expand during this period, despite a crash in world prices. While prices declined from a high of 28 cents per pound in 1926 to an average of 10 cents per pound during the depression, between 1930 and 1936, exports increased from 3 million to 4 million 60 kilogram bags. ${ }^{13}$ Throughout the period of coffee expansion in the twentieth century, departmental and the national governments were able attract foreign capital to help fuel the import substitution industrialization of the 1930's. Along with increased customs receipts from imports, which provided the major source of income for the government up until mid-century, the "Dance of the Millions" resulting from the indemnification for the U.S.'s role in the loss of Panama, also provided capital for the rapid industrialization that occurred during this period. ${ }^{14}$

While industrial production increased by approximately 20 percent between 1925 and 1929, capital investment in Colombian industry grew at an astounding rate of nearly 50 percent, enabling the country notes Bergquist, to embark upon an aggressive import substitution industrialization policy as a result of the excess installed capacity. ${ }^{15}$

These rapid demographic and economic changes which gripped Colombia in the 1920 's and 1930's led to the creation of new channels of social mobility as well as a transformation of social relations between increasingly distinct classes. The passing of the

${ }^{13}$ Bergquist, Labor, p. 295.

${ }^{14}$ Bergquist, Labor, p. 296.

${ }^{15}$ Bergquist, Labor, p. 306. 
artisanal system of production gradually gave way to the rise of a new system based on wage labor in both the countryside and in the cities.

\section{THE NASCENT LABOR MOVEMENT'S STRUGGLE TO ASSERT ITS AUTONOMY: 1910-1928}

The period from the turn of the century, but more significantly the years 19101928 , constitutes one of the most significant eras in the historical development of the Colombian labor movement. First, viable labor unions, as elsewhere in Latin America, did not appear on the Colombian scene until after the turn of the century. An industrial infrastructure began to arise in the wake of the expansion of a coffee export - oriented economy which had become predominant by the 1880 's.

This industrial expansion was complemented by incredible urban population growth. In the 1870's the population of Bogotá began to grow rapidly: by 1881, the city counted 84,723 inhabitants, a short three years later 95,761 and 120,000 by $1912 .{ }^{16}$ Bogotá's rapid population growth was mirrored in other regional capitals. Table 6:3 shows the spectacular growth of Colombia's most important cities during the period 1905-1951.

TABLE 6:3

Population of Departmental Capitals, 1905-1951 (thousands)

\begin{tabular}{llllll}
\hline Capital & 1905 & 1918 & 1928 & 1938 & 1951 \\
\hline Bogotá & 100 & 144 & 235 & 330 & 648 \\
Medellín & 55 & 79 & 120 & 168 & 358 \\
Cali & 31 & 46 & 123 & 101 & 284 \\
Barranquilla & 40 & 65 & 140 & 152 & 280 \\
Cartagena & 10 & 51 & 92 & 85 & 129 \\
Manizales & 25 & 43 & 81 & 86 & 126 \\
Bucaramanga & 20 & 22 & 44 & 51 & 112 \\
Ibagué & 25 & 30 & 56 & 61 & 99 \\
Cúcuta & 15 & 29 & 49 & 57 & 95 \\
Pasto & 31 & 29 & 43 & 50 & 81 \\
Santa Marta & 10 & 18 & 31 & 33 & 47 \\
Neiva & 18 & 25 & 30 & 34 & 50 \\
Popayán & 28 & 20 & 32 & 30 & 44 \\
Tunja & 8 & 11 & 19 & 20 & 27 \\
\hline
\end{tabular}

Sources: National censuses. Summary data on which the table is based is found in Zambrano, La Intervención Económica del Estado en Colombia, p. 102 and McGreevey "Urban Growth in Colombia," p. 390.

${ }^{16}$ Sowell, "The Early Latin American Labor Movement," p. 37. 
There were 13 factories in Bogotá by 1916, 25 in Antioquia, ten in Atlantico and eight in Bolivar. ${ }^{17}$ Not only did the well-known success stories of industrialization such as Medellín and Bogotá take place, but cities that had particular geo-physical advantages such as Barranquilla also benefitted. Barranquilla was privileged to be situated on the Magdalena River, connected by the Bolivar Railroad to Puerto Colombia, and served as the nation's coastal link to the interior on the major export-import route. Between 1883 and 1900, 12 industries were created, including production of foods, liquors and hats to serve a growing regional market. ${ }^{18}$ Between 1901 and 1920, 42 industries were established, and the city counted 30 factories that appeared between 1921 and 1925 in the manufacturing sector. 19

In Bogotá, the Bavaria brewery was the first major permanent industry, founded by a German immigrant in 1891, and employing 300 male and female employees. The brewery provided a number of benefits typically enjoyed by German counterparts in German factories such as housing, health insurance, loans, sick pay, and two liters of beer per day. ${ }^{20}$ The company offered the highest wages in the city, and its success led its owners to start a profitable glass factory in 1896.21 Women were also brought into the labor market in increasing numbers. At the cigarette factory "El Rey del Mundo," which was founded by the same German family and employed 50 women in 1904, workers were said to have been forced to work like "human machines": German insistence on discipline sometimes led workers to complain about management inflexibility. ${ }^{22}$

Up until 1910, only modest progress had occurred in labor organization. This was principally the result of general economic stagnation, setbacks suffered by the artisans in the closing decade of the nineteenth century, the transitional nature of the urban economy as

${ }^{17}$ Molina, Las Ideas Socialistas, p. 194.

${ }^{18}$ Cesar Mendoza. Ramos, Surgimiento y Desarrollo de la Clase Obrera en Barranquilla, paper presented at the 3rd Congress of Colombian History, Universidad de Antioquia, Medellín, Colombia, November (1981) p. 2.

${ }^{19}$ Cesar Mendoza Ramos, Surgimiento, p. 4.

${ }^{20}$ Sowell, "The Early Latin American Labor Movement," p. 35.

${ }^{21}$ Sowell, "The Early Latin American Labor Movement," p. 35.

${ }^{22}$ As a visitor remarked during a visit to the factory. See Sowell, "The Early Latin American Labor Movement," p. 36. 
more and more artisans were turned into proletarians, and the absence of leadership and relevant ideas which could provide the impetus for such a movement.

\section{ARTISANS, SOCIALISTS, ANARCHISTS, AND WORKING CLASS POLITICS}

Alongside the anarchist and socialist influences on working class organization during the first decades of the twentieth century was the persistent influence of artisans. By 1893, the National Institute of Artisans, with its practical focus on improving crafts, had been reorganized, the Taller Modelo providing artisan training was fully funded by artisan and government contributions by 1896, and the Salesian Brothers had created their Instituto Salesiano in 1890 to provide crafts training in carpentry, weaving and shoemaking. ${ }^{23}$

The best organized and most numerous labor organizations at the end of the nineteenth century were artisan. Despite efforts to avoid partisan political entanglements generally these early organizations were influenced by one of the two major parties. Early artisan organizations included the Typesetters' Society (1887), the Tailor's Society (1899) and the Cobblers' Society (1899), the latter two founded with support from the typesetters. ${ }^{24}$ The first legally recognized union in the twentieth century was the Sociedad de Artesanos de Sonsón. Antioquia which was established in 1909 by tailors, cobblers, carpenters and other independent artisans, and was probably founded under the guidance of Conservative clergy. 25 These organizations, like the contemporary mutual aid societies discussed in Chapter Five, were generally concerned with short-term economic benefits for their members and were very passive. They generally strove to avoid overt involvement in partisan politics.

In 1904, strong artisan influence was also apparent in the Unión de Industriales y Obreros' tariff petition to congress and the peaceful protest march by 2,500 workers in front of the president's residence in an unsuccessful bid to have tariffs raised. ${ }^{26}$ El Faro and $E l$ Yunque, the former a Liberal and the latter a moderate newspaper were founded in

${ }^{23}$ Sowell, "The Early Latin American Labor Movement," p. 277.

${ }^{24}$ Sowell, "The Early Latin American Labor Movement," p. 168.

${ }^{25}$ Urrutia, Development, p. 54.

${ }^{26}$ Sowell, "The Early Latin American Labor Movement," p. 290. 
1905 to promote artisan interests such as tariff protection and educational reforms. ${ }^{27}$ Both newspapers were closed when Reyes began to view them as potential threats to his government.

One should not be surprised to find that the first modern labor organizations were alliances of artisans and proletarians, but also often included the strange bedfellow, industrialists. The weekly El Obrero Colombiano was published during this period and was strongly influenced by the Catholic Church. The newspaper was financed by entrepreneurs and was dedicated to promoting the reformist ideas of Leo XIII's Papal Encyclical Rerum Novarum. ${ }^{28}$ One reason for this strange collaboration may be that some of the entrepreneurs themselves were successful craftsmen who had escaped proletarianization. Sowell cites one such example, shoemaker Marín Silva, whose shop expanded until he employed a total of 30 people. ${ }^{29}$ His shop had two sales rooms and offered several different styles of shoes. Sowell further notes that Silva's shop was "probably typical of shops whose owners had taken advantage of the division of labor to expand their productive capacity. The workers who toiled for Silva and other industrialists probably faced a life of wage labor that offered some the hope of achieving the independence of the artisan and only a very few the status of the industrialist." 30

A group of intellectuals, artisans and workers, many of them Liberals, organized the moderate Workers Party in 1904. Wrote antioqueño Luis Vives of the new party:

"Si el Partido Obrero se organiza, uno de sus principales cuidados será negarles votos electorales a individuos que no se comprometan a hacer esfuerzos iguales, por lo menos, a los del doctor Rafael Uribe Uribe en servicio de la libertad de los obreros y contra la desigualdad que echa sobre éstos la carga de la esclavitud militar." 31

The Workers Party, which after 1909 would abandon its alliance with the Uribista "Social Welfare" Liberals, initially served as a virtual electoral mechanism for the Liberal Party.

${ }^{27}$ Sowell, "The Early Latin American Labor Movement," pp. 293-294.

${ }^{28}$ Ricardo Sanchez, Historia Política de la Clase Obrera, p. 39.

${ }^{29}$ Sowell, "The Early Latin American Labor Movement," pp.285.

${ }^{30}$ Sowell, "The Early Latin American Labor Movement," pp.285-86.

${ }^{31}$ Molina, Las Ideas Socialistas, p. 198. 
Other labor unions began to be organized, most important among them the the Unión Nacional de Industriales y Obreros in 1910 (UNIO) and the Unión Obrera Colombiana in 1913 (UOC). As Sowell notes, the unions became more overtly involved in partisan politics: "Partisan efforts to use labor organizations intensified after the collapse of the Reyes quinquenio; Uribista Liberals fared well with the industrialists of the UNIO, while the Republicans found more favor with the UOC and fledgling socialist groups." 32 The Workers Union backed the Republicans in 1909. In 1911, the Workers Party and the UNIO sided with the Liberals. ${ }^{33}$ UNIO, which had attempted to avoid partisan political involvement in early efforts to unify workers by supporting the independent Workers Party, aligned itself again with the Uribe Uribe Liberals in the 1913 elections, foregoing an alliance with the Workers Party. ${ }^{34}$ It later switched its allegiance to the Republican-led coalition of 1915 , its rhetoric shifting towards a more socialist stance in an effort to counter the pro-social positions of the competing Unión Obrera Colombiana. ${ }^{35}$

It was not until the establishment of the Union Obrera Colombiana that labor organizers formally recognized the incompatibilities inherent in creating a union dedicated to furthering workers' rights which included industrialists in its ranks. The Unión Obrero Colombiana was the first attempt to centralize the worker's movement and free it from the two traditional parties. The new union, unlike its predecessors, excluded industrialists, limiting its membership to craftsmen and wage laborers. It stated its objectives in the following manner:

La Unión Obrera de Colombia es una institución libre e independiente, en la cual tienen cabida todas aquellas personas que ejerciendo un arte u oficio ó trabajando de salario estén convencidos de la necesidad de la unión obrera par a el mejoramiento moral, intelectual y material de las clases proletarias de Colombia....La Unión Obrera se dedicará, de preferencia: 1. A propagar en toda la república la idea de la unión de los obreros, libre e independientemente, alejándoles de las luchas político-partidistas... ${ }^{36}$

${ }^{32}$ Sowell, "The Early Latin American Labor Movement," p. 362.

${ }^{33}$ Sowell, "The Early Latin American Labor Movement," p. 315.

${ }^{34}$ Sowell, "The Early Latin American Labor Movement," pp. 303-315.

${ }^{35}$ Sowell, "The Early Latin American Labor Movement," p. 323.

${ }^{36}$ Quoted in Ricardo Sanchez, Historia Política de la Clase Obrera, p. 40. 
Soon, the UOC also became embroiled in partisan politics however, at different times siding with the Republicans or Liberals. The union advocated several reforms that if enacted, would greatly benefit workers. These included: a program of public education, a literacy campaign, protection of national industries, increased wages, creation of a savings bank, and protection of male and female workers against "exploitation" by "capitalists." 37

The union represented an important transition in labor organization. Unlike its predecessors, it was not founded under the ideological tutelage of one of the traditional parties or the short-lived but influential moderate conservative, moderate liberal alliance known as the Republican Party. The UOC's ideological role in the development of an organized labor movement in Colombia was to raise artisan and worker consciousness of their "distinctness" from industrialists, as well as to outline labor's stance on a number of issues which would also be taken on by later unions. Although the union counted nearly 3000 members by August 1914, it only lasted until 1916 when it was replaced by a more independent Partido Obrero. ${ }^{38}$

In 1915, workers entered into an alliance with both Liberals and Republicans to challenge the ruling Conservatives in municipal elections. In a close election, the alliance did well, even managing to place three workers on the council. However, according to Amorocho, the Liberals and Conservatives struck a clandestine agreement which allowed them to exclude workers from the appointment process, instead placing Liberal and Conservatives in local offices. ${ }^{39}$ Whether or not such an agreement existed, as a result of the lack of appointments of workers to local offices, workers felt that they had once again been betrayed by the Liberals and Republicans.

During the period 1916-1924, workers began to assert their independence by attempting to establish a legitimate organizational framework independent of major political party domination that could serve to represent effectively the interests of the working class. More and more, the movement embraced left-wing political philosophies such as anarchism, socialism and communism as guiding ideologies. As early as 1910 certain leftist newspapers had cropped up, such as the Comunista of Cartagena. One article in the same year called for the establishment of an independent labor movement, secure in the fact that "los núcleos más avanzados del país-obreros en primer lugar-tratarán de

\footnotetext{
${ }^{37}$ Sowell, "The Early Latin American Labor Movement," p. 317.

${ }^{38}$ Ricardo Sanchez, Historia Política de la Clase Obrera, p. 40.

${ }^{39}$ Sowell, "The Early Latin American Labor Movement," p. 368.
} 
independizarse de los partidos tradicionales, y no únicamente en las capitales sino inclusive en ciudades de provincia..." 40

Frustrated at their impotence to change their subordinate role in society, workers increasingly turned towards more radical groups and ideologies in a collective effort to enhance their position. In January 1916, a new Partido Obrero was founded in Bogotá by 800 workers. ${ }^{41}$ The new union's determination to separate itself from the dominant political parties is clearly stated in its Manifesto: "Convencidos estamos de que no existen partidos honrados sino que la humanidad sólo se divide en dos clases: la una trabaja y sufre hambre y miseria; la otra consume y no produce." 42 The party's founders, many of whom had been active in the union's predecessor, the UOC, were convinced of the need to withdraw from the partisan political battle in which "ha quedado más de una vez nuestra sangre." It also argued that illiteracy had helped maintain the workers' ignorance: "para blanco de las balas fratricidas en las contiendas armadas, o de esclavos de los caudillos en las luchas electorales."

The Party's mouthpiece, also called the Partido Obrero, like the Uribista Liberals, favored active state intervention on behalf of labor, and many of the same goals the UOC had adapted such as worker indemnification for workplace accidents, a limit on the work day, workplace safety, and a minimum wage. ${ }^{43}$ The party viewed the Liberal Party as its chief competitor for the minds of the working class, Workers Party leaders arguing that abstention was preferable to voting for one or other of the two main parties. Party leaders however could also be pragmatic, noting the value of striking bargains with the Liberals, Conservatives, or Republicans on occasions when such temporary accords could actually benefit their constituents. The Workers Party called for social change, viewing society as being composed of two classes, the élite class that denied workers the right to enjoy equally the fruits of society and of course the workers themselves. ${ }^{44}$

The Workers Party was strongly criticized by Liberals such as Ramón Rosales, who would later be appointed as Liberal President Alonso López Pumarejo's Minister of

40Molina, Las Ideas Socialistas, p. 199.

${ }^{41}$ Sowell, "The Early Latin American Labor Movement," p. 324.

${ }^{42}$ The following quotations from the party's Manifesto are taken from Molina, Las Ideas Socialistas, pp. 201-202.

${ }^{43}$ Molina, Las Ideas Socialistas, p. 202.

${ }^{44}$ Sowell, "The Early Latin American Labor Movement," p. 324. 
Labor. Rosales charged that the new union was really a front for the Republican Party, and that labor's only true ally was the Liberal Party. ${ }^{45}$

The following year, a Central Workers' Syndicate was created to study socioeconomic conditions of workers and the poor in the capital. Pablo Mancera, who had been actively involved in its creation as well as in UOC activities concluded that a socialist solution was necessary to ameliorate the appalling conditions of the poor. ${ }^{46}$ In May 1919, a National Workers Congress was convened to draw up a reform platform. The same year witnessed the foundation of the Socialist Party of Colombia.

Before continuing the discussion of the development of unions that were strongly influenced by socialism, we should first look at the early influence of the anarchists. Anarchist organizations were deeply involved in more radical forms of worker organization and protest in the first two decades of the twentieth century. Anarchist organizations were particularly active in organizing strikes and worker protests.

Although little research has been done on the influence of anarchists and anarchosyndicalists in the Colombian labor movement, it is clear that in the period 1910-1919, they were the dominant radical force in labor organization. ${ }^{47}$ Alba cites, as evidence of anarchist involvement in the early phases of the labor movement, a number of articles sent from Bogotá to anarchist newspapers in other countries as early as 1910.48 These articles show that at the time, there were already many "union sympathizers acquainted with anarchist thought."49 As was the case in Chile, Colombia's anarchists and anarchosyndicalists appear to have been overwhelmingly "home-grown." 50 This stands in sharp

${ }^{45}$ Sowell, "The Early Latin American Labor Movement," p. 328.

${ }^{46}$ Sowell, "The Early Latin American Labor Movement," p. 332.

${ }^{47}$ It is interesting to note, for example, that Urrutia has dedicated less than two pages of his 260-page analysis of the development of the Colombian labor movement to the influence of the anarchists and anarcho-syndicalists in labor organization.

${ }^{48}$ Victor Alba, Politics and the Labor Movement in Latin America (Stanford, California: Stanford University Press, 1968), p. 56.

${ }^{49}$ Alba, Politics and the Labor Movement, p. 56.

${ }^{50}$ For a brief comparative account of the development of working class movements in Chile, Argentina, Venezuela and Colombia see Charles Bergquist's excellent interpretive work, Labor in Latin America, (Durham, N.C: Duke University Press, 1978). For a concise look at Chile, Argentina and Brazil, see Skidmore's essay, "Workers and Soldiers: Urban Labor Movements and Elite Responses in 20th Century Latin America," in Elites, Masses and Modernization in Latin America edited by Bradford Burns and Thomas E. Skidmore, (London, Austin: University of Texas Press, 1978). 
contrast to the Argentine case, where large numbers of European immigrants who had experience with anarchist and anarcho-syndicalist ideas and organizations exerted a strong influence on the development of labor. Nevertheless it is likely that anarchist ideas were transmitted to Colombian workers, particularly in the transportation sector, through contact with foreigners in Colombia's ports.

Fluharty notes that workers in both mines and ports turned to class synidicalism of "anarchistic type" that was in his opinion, "hazily cbjectiveless." He continues, "but it was based upon a consciousness of class differences and injustices, and vague as it was, it was to challenge the old order."51 Molina also argues that the anarchist groups lacked direction, particularly during strike activities. He writes:

El anarquismo, en boga a la sazón en Europa, tal vez contagió a nuestros huelguistas del gusto por los saqueos y por la destrucción de bienes, como las líneas telefónicas. Esa deformación de la huelga había de servir de excusa a los guardianes del orden para reprimirla, y a las clases propietarias para alinearse en contra de los contestatarios. ${ }^{52}$

Further evidence that suggests a strong early influence of the anarchists was the popular demonstration of artisans in Bogotá in 1919. Reeling under the impact of the economic strains brought about by the first World War, the government of Don Marco Fidel Suárez had decided to purchase inexpensive uniforms for its police force from abroad. A group of garment workers and craftsmen was organized by the anarchists to pressure the government into purchasing only the material abroad while allowing the uniforms to be made in Colombia. Although the government had decided to accede to their demands, this information was not widely available and the demonstration turned into a riot. Anarchist slogans were chanted in the streets and anarchist graffiti soon covered walls throughout downtown Bogotá. 53 A crowd of between five and ten thousand gathered in the Plaza Bolívar on Sunday, March 16. When Suárez attempted to address the crowd, he

51Fluharty, Dance of the Millions, p. 37.

52Molina, Las Ideas Socialistas, p. 203.

${ }^{53}$ Fals Borda, Subversion and Social Change, p. 123. Miguel Urutia (Development) insists that the entire demonstration and resultant loss of life was unnecessary, pointing out that the government had annulled the decree on the 15th of March, the day before the demonstration (Urrutia, p 63-64). In fact, the government only suspended bids for uniforms on that day. In early April, an order was placed for 30,000 yards of cloth from a U.S. company according to La Gaceta Republicana, April 11, 1919 (Sowell, "The Early Latin American Labor Movement," p. 337). 
was pelted with stones. ${ }^{54}$ Government reaction was swift. A state of siege was declared the same day and the police attacked the crowd with machine guns. Dozens of demonstrators were injured in the bloody melee which ensued, and the police made more than 500 arrests. .5

The greatest influence of the anarchists during this period was not in the capital, however, but rather in the port cities along the Caribbean coast. The rivers, coastal ports, and railroads were fertile ground for the early growth of labor organizations. Generally speaking, it was not among Colombia's incipient manufacturing industries that a workingclass movement began to form. Working class unions began to slowly spring up throughout the country along the nation's transportation arteries.

Since Colombia depended on the rivers and railroads to transport its exports to the Caribbean ports, fluvial workers, coastal longshoremen and railroad workers had a better bargaining position than did unskilled wage laborers in the incipient industries of the urban areas. Any prolonged work stoppage could threaten Colombia's ability to export, and thus its ability to purchase critically needed imports from abroad. Even strikes of short duration could translate into costly losses in export revenues. Table 6:4 gives some indication of Colombia's dependence on these critical transportation routes.

${ }^{54}$ Sowell, "The Early Latin American I abor Movement," p. 337.

${ }^{55}$ Alba, Politics and the Labor Movement, p. 56. Molina puts the number at seven killed and 15 injured. He also notes that the socialists claim this episode gave them their first martyrs while Sowell and Alba note that the crowd was probably incited by anarchists who had also posted notices of the protest throughout Bogotá. Since both anarchists and socialists were actively wooing labor at this time, it is quite possible that organizers from both groups were involved in the demonstration. 
TABLE 6:4

Freight Moved by the Railroad and Riverboats (in tons)

\begin{tabular}{ccc}
\hline \hline Year & $\begin{array}{c}\text { Freight Moved on the } \\
\text { Magdalena River }\end{array}$ & $\begin{array}{c}\text { Freight Moved on the } \\
\text { Railroads and Air Cables }\end{array}$ \\
\hline \hline 1923 & 582,000 & $1,582,000$ \\
1924 & 663,000 & $1,820,000$ \\
1925 & 776,000 & $2,101,000$ \\
1926 & 779,000 & $2,650,000$ \\
1927 & $1,977,000$ & $3,068,000$ \\
1928 & $1,521,000$ & $3,315,000$ \\
1929 & $1,307,000$ & $3,134,000$ \\
1930 & 902,000 & $2,197,000$ \\
1931 & 677,000 & $1,917,000$ \\
1932 & 763,000 & $2,128,000$ \\
1933 & 934,000 & $2,340,000$ \\
& & \\
\hline
\end{tabular}

Source: Miguel Urrutia, p. 88.

The first effective organization of workers' groups determined to press collectively demands for better working conditions and wages in Colombian history occurred among the fluvial and coastal port workers.

During the brief period of anarcho-syndicalist hegemony, workers' organization in the coastal regions was spurred by post-war inflation which was cutting into wages. Strikes such as the famous general strikes that paralyzed Colombia's coastal ports for a short period in 1918, were anarchist-led. The anarchists were the first organized group in Colombia to consistently use this new method of asserting working class interests.

While anarchist influence was most apparent where strike organizations had successfully organized along the Caribbean coast and railway lines, the socialists were making headway in the capital.

The 1919 National Workers Congress called for the creation of the Socialist Party during its May meeting, and called for several reforms to alleviate poor living conditions of the poor that young Alfonso López referred to as "miseria" that "oppressed the heart." 56 During a period in which exports had fallen off as demand in Europe and the United States was curbed by the first world war, salaries for workers also declined. ${ }^{57}$

56 López Pumarejo, Diario Nacional, 1922, cited in Molina, Las Ideas Socialistas, pp. 208-209.

${ }^{57}$ Ricardo Sánchez, Historia Política de la Clase Obrera, p. 44. 
Thoroughly dominated by artisans, the new Socialist Party became a reformist movement with a meliorative, Christian orientation. Before the Labor Congress was convened, Colombian Congressman José D. Celis, active in Bogotá's Mutual Benefit Society, had written: "when the hour arrives for electing the members of this labor confederation, we should look toward the truly socialist workers; those who desire the expansion and triumph of socialism. To this new society we should not admit any one who favors or is an agent of political ideas other than ours. We shall try to save the labor movement from professional politicians..." 58 José Celis, along with Manuel Antonio Reyes, both artisans, were the primary authors of the Socialist Platform. The authors later insisted on including the rule that only workers be allowed to join the organization. 59

A Gaceta Republicana editorial noted that the socialism advocated in Colombia "no se basa en el despojo de los acomodados y en la persecución de las clases superiores. El socialismo que nos enseñó Cristo busca solamente asegurar la equidad dentro de las relaciones comerciales y la igualdad según los principios democráticos."60 Another article in the Gaceta relating a draft article from the Socialist Platform states, "Given the various tendencies of socialism, each country needs a special type of socialism according to the intellectual state of the people, the development of industry, etc. The new political party shall be called the 'Socialist Party,' but as has been said, a special socialism tailored to our people, that is to say, Christian." ${ }^{1}$ Article two of the final document proclaims that the Partido Socialista is based upon "los principios del socialismo moderado...sus doctrinas no aceptan en esencia el anarquismo, ni el colectivismo exagerado ni el comuniso...El fin principal, es la 'lucha en defensa y por la elevación del pueblo trabajador que, guiado por la ciencia, tienda a realizar una libre e inteligente sociedad humana basada sobre la propiedad colectiva de los medios de producción."'62 In Article Four the point is reiterated, adding

${ }^{58}$ Urrutia, Development, pp. 60-61.

${ }^{59}$ Urrutia, Development, p. 62.

60Molina, Las Ideas Socialistas, p. 211.

${ }^{61}$ Gaceta Republicana, (February 15, 1919). Quoted in Urrutia, Development, p. 62.

${ }^{62}$ Ricardo Sánchez, Historia Política de la Clase Obrera, p. 43, Molina, Las Ideas Socialistas, p. 214. Excerpts from the document appear in both Sánchez, pp. $42-44$ and Molina, pp. 214-219. 
that the Socialist Party did not seek the abolition of the state, society, property or private capital, though it did favor the elimination of unjust monopolies. ${ }^{63}$

The very first article of the Workers Assembly decreed its independence from the established parties and religions, declaring that it was instead an organization dedicated to the fight for the rights of workers. ${ }^{64}$ Articles Five, Seven, and Eight outline the major reforms sought by the new organization. They included: a government by and for the people responsive to the needs of the 'pueblo'; educational reform and a major literacy drive; legislation on the use of common lands; legislation guaranteeing hygienic housing conditions; tax reform; a list of specific demands that included 30 points, among them including, maternity benefits, retirement benefits, 8-hour work day, a tax reduction for articles of necessity, obligatory public schooling, reform of workmen's injury laws, electoral reform, nationalization of the army, police, schools, and telecommunications, 'anti-alcoholic' legislation, Habeas Corpus, protective tariffs on nationally produced goods, and the separation of church and state. ${ }^{65}$

Although the creation of the Socialist Party heralded the first modern formal effort of workers and intellectuals to break with the traditional parties, the founding members believed that forging temporary alliances with other parties in municipal and national elections was important if the candidate could further the interests of workers. Article 14 makes it clear that such alliances were still considered necessary:

Todos los Directorios Socialistas están en el deber de trabajar porque el partido obtenga el mayor número de representantes en los cuerpos colegiados y para el efecto, cuando las necesidades y conveniencias lo exijan, podrán pactar con los demás partidos afines, o que tengan mayores puntos de contacto con las aspiraciones de este programa, siempre que los candidatos aliados se comprometan a defender y dar su voto por los proyectos que presenten los candidatos socialistas, requisito sin el cual no habrá pacto, pudiendo a la vez por motivos de reciprocidad los candidatos socialistas, hacer lo propio con los proyectos que presenten los candidatos aliados, cuando no pugnen en nada con los intereses del proletariado. ${ }^{66}$

\footnotetext{
${ }^{63}$ Ricardo Sánchez, Historia Política de la Clase Obrera, p. 43.

${ }^{64}$ Ricardo Sánchez, Historia Política de la Clase Obrera, p. 42.

${ }^{65}$ Molina, Las Ideas Socialistas, pp. 217-218.

${ }^{66}$ Molina, Las Ideas Socialistas, pp. 218-219.
} 
Nevertheless, the party ordered its faithful to abstain from elections in 1919 , preferring instead to wait until the party had had an opportunity to recruit workers to run as their own candidates. 67

Workers organizations, particularly craft unions were encouraged, and in the months following the Labor Congress, a union of tailors was established in the capital with some 200 members, the Sociedad de Zapateros, a union of builders was organized, and 200 carpenters and cabinetmakers met to discuss the establishment of a trades organization, these groups joining the 20 labor organizations that already existed in Bogotá in 1919.68 Urutia notes that the organizational efforts were also successful in the departments, citing the fact that twelve newspapers in other parts of the nation were supporting attempts to organize workers. ${ }^{69}$ A labor central was established in April, which by June counted more than 100 affiliates, including railway workers and several other working class organizations. ${ }^{70}$

Although the Socialist Party was dissolved in 1924, during its short life span, several goals related to the protection of workers and the advancement of labor organization were accomplished. In addition to the establishment of several labor unions, both artisan and industrial, another important benefit was the enhanced degree of artisan and worker consciousness of their distinct position in society. Such awareness included workers' need for basic human benefits such as rudimentary health care and sufficient wages to support their families, as well as a realization of the value of their role as the nation's producers. During this period, more than 60 newspapers with a socialist orientation were being published, ${ }^{71}$ including El Socialista in Bogotá, La Lucha in Girardot, El Taller in Manizales, El Rebelde and El Látigo of Medellín, in addition to the Gaceta Republicana which had already been publishing in the capital. ${ }^{72}$

Another area in which the party had an impact was in organizing groups of workers to defend their economic interests and in popularizing the strike as the method of last resort

${ }^{67}$ Urrutia, Development, p. 61.

${ }^{68}$ Only seven of these organizations had been legally recognized. Urrutia,Development, pp. 60-62.

${ }^{69}$ Urrutia, Development, p. 62.

${ }^{70}$ Sowell, "The Early Latin American Labor Movement," p. 336.

${ }^{71}$ Ricardo Sánchez, Historia Política de la Clase Obrera, p. 47.

${ }^{72}$ Molina, Las Ideas Socialistas, p. 221. 
to obtain workers' demands. The socialists helped organize several work stoppages, supporting the Dorada Railway Strike in 1920 and the strike against the English mining company Segovia in 1919, both resulting in outcomes favorable to the laborers. Another notable strike occurred during 1920, the Bello Textile strike near Medellín. An article in the Socialista describes the events that occurred:

La huelga estalló súbitamente sin preparación. De un momento a otro las obreras decretaron el paro del trabajo y se situaron en las puertas de la fábrica a impedir que sus compañeros, que estuvieran por fuera, entraran. En un principio los hombres se negaron a secundarlas y ellas los dejaron en libertad de hacer lo que quisieran, limitándose a gritarles en las puertas ique debían cambiarse y llevar faldas, dejándoles a ellas los pantalones! Al fín se generalizó la huelga y los obreros decidieron acompañar a las obreras...Los huelguistas piden la destitución de los actuales vigilantes. Es directora del movimiento la señorita Betsabé Espinosa. Cuando se decidió el paro, la señorita Betsabé dirigió a sus compañeros un gran discurso...hoy se vino para Medellín, con algunas compañeras, a entenderse con el gerente y con el gobernador. ${ }^{73}$

In Medellín more than 3000 individuals were assembled by the Socialists to support the strike. ${ }^{74}$ Although the Archbishop of Medellín agreed to mediate the strike, the strikers had already achieved most of their demands. ${ }^{75}$ It is important to note also that the role of women in early industrial development, such as those working for Bavaria in Bogotá and those who led the Bello strike was not lost on the Socialists. In the first paragraph of the preamble to the Socialist Platform of 1919, the party pledged to protect the rights of workers of both sexes. Other strikes in which Socialists played a role were the Barranquilla Railway strike, the strike by more than 2000 seamstresses and cobblers in Bucaramanga, a mining strike in Marmato, and the Valle railway strike, all of which took place in $1920 .{ }^{76}$

The party also made inroads in politics. In Medellín, bastion of moderate conservatism, the 1919 electoral outcome showed the Conservatives winning in local elections with 2,177 votes compared to the Socialists who received 1,039 and the Liberals

${ }^{73}$ Ricardo Sánchez, Historia Política de la Clase Obrera, pp. 45-46.

${ }^{74}$ Molina, Las Ideas Socialistas, p. 222.

${ }^{75}$ Molina, Las Ideas Socialistas, p. 222.

76Ricardo Sánchez, Historia Política de la Clase Obrera, pp. 46-47. 
who received only 934 votes. ${ }^{77}$ Between 1919 and 1921 , Socialists also did well in a number of elections gaining a majority in some town councils, as well as positions in departmental assemblies and Congress. ${ }^{78}$

The infatuation of the Socialist press with the Russian Revolution was apparent during this period, though the revolution was idealized and Leninist strategies, though discussed in the press by Luis Tejada in his 'Oración para que no muera Lenin,' were never seriously considered by the reformist-oriented, moderate mainstream of the party. ${ }^{79}$ This lack of radicalism can partly be accounted for by the overwhelming influence of the socially conservative artisans and the small numbers of the Colombian proletariat, and partly as a result of the unlikely applicability of the Soviet model to the Colombian case. We must keep in mind that the Socialist Party's motto emblazoned on a field of red extolled Liberty, Equality and Fraternity, the bourgeois cry of the French Revolution of 120 years earlier, not dictatorship of the as yet incipient proletariat. When the term proletarian was used in the Colombian context, it referred equally to the artisan and the factory laborer: ${ }^{80}$

The independence of the Socialist Party was short-lived. When in 1922 it seemed that Liberal candidate General Benjamín Herrera, who demonstrated pro-labor, prosocialist sympathies, and who seemed to have an excellent chance of unseating the

${ }^{77}$ Molina, Las Ideas Socialistas, p. 224.

${ }^{78}$ Ricardo Sánchez, Historia Política de la Clase Obrera, p. 48.

${ }^{79}$ Molina, Las Ideas Socialistas, p. 223 and Ricardo Sánchez pp. 48-49, both mention that the Russian Revolution had a modest impact on the development of Colombian socialism, but only Sánchez accounts for the pro-Soviet communists' lack of influence in altering the political and programmatic direction of the Socialist Party. As is typical of contemporary Colombian communist historians, Sánchez attributes the lack of influence of application of Soviet communism not to its irrelevance to the Colombian case, but rather to the reformist attitude on the part of the party's leadership. He writes "...la simpatía por la revolución rusa aumentaba la idea de un mañana sin explotación. La influencia reformista en los dirigentes conducía al oportunismo y a confiar en las bondades del sistema electoral. No contó entonces el movimiento de masas con una orientación política y programática marxista o revolucionaria que le hubiese permitido solidificar la línea por la independencia política del movimiento y por el partido obrero y socialista." (Sánchez, p. 49.) While Sánchez is correct in noting this reformist orientation, he fails to mention that the socialist leadership's position probably reflected accurately the views of the organization's membership. The Party itself was primarily comprised of artisans of middling class, who owned their means of production, probably considered themselves good Catholics and could never support a leadership advocating the violent overthrow of the ruling élite and its replacement, as in the case of the Soviet Union, with the dictatorship of the vanguard of the proletariat (the Communist Party). Some members of the party were obviously influenced by the idea of a worker's utopia implied by the success of the Russian Revolution, but this influence never translated into a radical program.

${ }^{80}$ Molina, Las Ideas Socialistas, p. 221. 
Conservatives, socialists joined in an anti-Conservative coalition. ${ }^{81}$ Two years earlier, Herrera had sounded the Liberal strategy when he stated in an interview in El Universal in Barranquilla, "No veo la razón para que se funde un tercer partido político en Colombia, cuando dentro del liberalismo caben todas las aspiraciones de los trabajadores, porque éste es carne de su carne y hueso de su hueso." 82

Although Herrera lost a close election to Conservative Pedro Nel Ospina, who was supported by the Catholic hierarchy, during the Convention of Ibagué convened after the elections, the Liberals adopted virtually in its entirety the social reform platform of the Second Socialist Party Congress that had been held in Honda in $1920 .{ }^{83}$ Once again, the Liberal Party was able to subvert efforts to create a viable workers challenge to the existing two-party political system and the social hegemony of the merchant and landed élite. More radical voices were to capture the leftist fringes of the labor movement while the mainstream of the working class cast its support to the party that had the best chance of improving its material lot. While many artisans and laborers were able to achieve certain short-term material goals as a result of the "top-down" pressure from the Liberal Party, at the same time the Liberal Party was in effect able to coopt the creation of an independent, working-class directed, labor movement.

The same year that witnessed the dissolution of the Socialist Party, 1924, also saw the creation of the Oficina Geineral del Trabajo by the Conservative government. The General Labor Office was charged with overseeing the implementation of a newly created social security system, the construction of housing for workers that had previously been authorized by the government, investigating workers' accidents, regulation of child labor and women's labor, technical and civic education of workers, working conditions for arrendatarios, enforcing Law 78 of 1919 and Law 21 of 1920 to be discussed below, and the elaboration of a labor code. ${ }^{84}$ Among the reasons cited for the interest in promulgating a labor code by the Conservative government's Minister of Industry include the following pronouncement:

\footnotetext{
${ }^{81}$ Molina, Las Ideas Socialistas, p. 225.

${ }^{82}$ Ricardo Sánchez, Historia Política de la Clase Obrera, p. 50.

${ }^{83}$ Molina, Las Ideas Socialistas, p. 227.

${ }^{84}$ Bernardo Tovar Zambrano, La Intervención Económica del Estado en Colombia 1914-1936 (Bogotá: Biblioteca Banco Popular, 1984), p. 148.
} 
precisa no olvidar-decía--que las grandes revoluciones sociales provienen, casi siempre, de una lamentable imprevisión por parte de quienes se hallan encargados de velar por la seguridad de los asociados; y no olvidar tampoco que estas medidas preventivas deben tomarse en obedecimiento a un principio de equidad y de justicia, recordando que al consagrar en la ley los justos derechos de las clases obreras, se robustece la acción nacional y se fomenta el industrialismo en el país, poniendo en armonía lo sintereses del proletariado con los del empresario capitalista. ${ }^{85}$

Although the laws were seldom enforced, generally ignored by both government and workers, they do demonstrate, along with the minister's comments, the government's desire to control labor and avoid its absorption by radical forces. Those who were "in charge of ensuring the security" of society, the élite-controlled government, must be ready to safeguard the present social relations to maintain harmony between the interests of the proletariat and industrialist.

\section{STRIKES AND REPRESSION}

The years 1918-1920 witnessed a number of strikes, particularly among transport workers and workers laboring in the foreign enclaves such as United Fruit and Standard Oil. In 1920, of 31 strikes registered by the government, 13 were in the transport sector, 13 in industry, 2 in mining and one in agriculture. ${ }^{86}$ Strikes among railway and port workers in Barranquilla, Cartagena, and Santa Marta led to riots in those cities. The Conservative government set a precedent which would long serve as its standard course of action in its efforts to aid in the resolution of labor-employer disputes: it declared a state of siege and sent in the troops.

In one such incident, on January 4, 1918 workers in Barranquilla demanded a 50 percent increase in their wages. Four days later, Cartagena teamsters and port workers also struck. The strikes, which were organized by the Sociedad de Artesanos y Obreros, were declared as a result of unmet demands for increased wages and better working conditions.. ${ }^{87}$ In Barranquilla, the workers obtained an increase of 50 percent. In Cartagena, the strike devolved into riots when workers' demands were not met, and a governmental declaration of a "stage of siege" was issued for the Caribbean coast. Troops were sent to the region, and the strike was broken after four days. Both Liberals and

\footnotetext{
${ }^{85}$ Zambrano, La Intervención Económica, p. 149.

${ }^{86}$ Zambrano, La Intervención Económica, pp. 122-123.

${ }^{87}$ Urrutia, Development, p. 56.
} 
Conservatives roundly condemned the violence of the strike and issued strong criticisms of the behavior of the strikers in newspaper editorials throughout the country. ${ }^{88}$

In the ensuing months, the government passed legislation prohibiting the meetings of "permanent strike committees," declared that a person who did not belong to a craft or enterprise of workers involved in a particular labor dispute could not represent the workers, and prohibited picketing. ${ }^{89}$ One strange provision also required that foreigners participating in strikes would be deported, leading Urrutia to believe that the strikes may have been led by foreigners who were anarcho-syndicalists. ${ }^{90}$ The strike spread to Santa Marta, and as in Barranquilla, although some sporadic violence accompanied the strike, the strike itself was largely successful in obtaining the workers' goals. The transport workers won a wage increase of 25 percent. ${ }^{91}$

In late November, railway workers and Bogotá cable car workers also went on strike. Urrutia believes that the railway strike, unlike the dockworkers strikes, was an example of a "responsible" strike. He notes that the strikes did not provoke condemnation by the Liberals and the Conservatives since they were conducted in a peaceful manner. He writes, "In contrast to the March events, the railroad strike of November 1919 illustrates the rationale [sic.] and effectiveness of serious trade union action."92 It seems for Urrutia then, that if a labor action was not peaceful, not within the legal parameters established by the state, it was not an effective expression of worker's rights, and therefore was an example of a pre-modem phenomenon that has no place in modern labor organization. Even though violent tactics were employed by the dockworkers, their demands were met despite condemnation from Liberals and Conservatives, while a peaceful bakers strike the same year was a complete failure. ${ }^{93}$ In the case of the Colombian rail workers, their

\footnotetext{
${ }^{88}$ Urrutia, Development, p. 57.
}

${ }^{89}$ These incidents are related in Urutia, Development, pp. 56-58.

${ }^{90}$ See Development, pages $57-58$.

${ }^{91}$ Urrutia, Development. p. 58.

${ }^{92}$ Urrutia, Development, p. 65.

${ }^{93}$ In this incident, the strike was generally peaceful. One riot was reported when bread was smuggled into Bogotá from the provinces. 
demands were achieved through peaceable means: the Girardot Railway workers received a 40 percent increase in their wages. ${ }^{94}$

The government response to the rash of strikes was to pass two key laws, Ley 78 of 1919 and Ley 21 of 1920, to help bring the process of labor-management relations under more direct vigilance and control by the state. Ley 78 outlined the conditions under which legal strikes could be carried out. The conditions included efforts to obtain more sanitary working conditions, better working hours, salaries, etc and that the strikes be undertaken in a peaceful manner. ${ }^{95}$ The law also regulated strikes in the public sector. Ley 21 of 1920 required direct negotiations between management and labor, and failing a successful resolution of the dispute at this stage required government mediation before a strike could be called, eliminating a labor strategy of surprise strikes. ${ }^{96}$ It also prohibited strikes in the public sector.

Although anarchists were active in many of the strikes during the two years 19181919 , and were very active in organizing workers during the ten years that led up to the great strikes of 1919, the Socialists and Liberals would come to clearly dominate the labor movement by 1919 . Workers were more strongly attracted to the traditional parties and the new, reformist-oriented Socialist Party. Reform-minded intellectuals from the élite were also drawn to the new Christian socialist ideas, but demonstrated no enthusiasm for anarcho-syndicalism. Colombian "leftists" had an established tradition firmly rooted in social reformism and utopian socialism that incorporated Christian teachings and which vehemently excluded militant action by workers that involved the destruction of property.

From the Gólgotas who believed all classes could live together in harmony in society but were also staunch free-traders as well as supporters of Murillo Toro, who believed in the economic intervention of the state in order to encourage economic growth, both of whom were active in the mid-nineteenth century, to Uribe Uribe's turn of the century call for more active participation of the state to remedy social and economic ills, the Colombian leftist tradition had always been peaceful and reformist. For most Colombian leftists, anarchism made no sense: it was viewed as a foreign-inspired ideology with no relevance to Colombian reality.

\footnotetext{
${ }^{94}$ Urrutia, Development, p. 65.

${ }^{95}$ Zambrano, La Intervención Económica, p. 124.

96Zambrano, La Intervención Económica, p. 125.
} 
Another important factor which kept anarchism from gaining wider acceptance among Colombian workers, virtually limiting its influence to workers in the transportation system that linked Colombia commercially to the outside world, was the willingness of city-dwelling proletarians who were still outnumbered by artisans, to accept the leadership of artisans in workers' alliances in the first decades of the twentieth century. As we have shown, although wage-earners were active in worker's organizations, socially and politically moderate artisans played a major role in creating the workers' organizations of the second decade of the twentieth century and played a central role in the creation of the Socialist Party. These factors limited the appeal of anarcho-syndicalism and communism to Colombian workers. Although the anarcho-syndicalists published the journal Claridad in the 1920 's their influence in the labor movement was greatly diminished after their brief involvement in the strikes of 1919.

Between 1921 and 1924, during a slump in the Colombian economy, there was very little strike activity. One Colombian historian argues that in addition to the general economic stagnation of those years, another reason for labor's inertia could have been its involvement in Liberal Party politics in 1921 and 1922.97 Labor, as we have mentioned, actively participated in Benjamín Herrera's 1922 presidential campaign.in an effort to unseat the Conservatives for the first time since the Núñez era.

Despite the marriage of convenience between Liberals, ex-socialists and workers, the next great wave of strikes was led by the Communist organizer Raul Mahecha. Mahecha, son of a physician, was a one time soldier who had served as an lieutenant in the Colombia Battalion in Panama. He had become active in labor affairs after participating in the abortive 1904 attempt to restore the state to Colombian sovereignty. Throughout the 1920's, Mahecha edited the leftist newspaper El Luchador. ${ }^{98}$

In 1924, 500 workers went on strike at the Colombian subsidiary of the Tropical Oil Company, which was controlled by Standard Oil of New Jersey, to demand better working conditions. An abortive strike had occurred at the same facility two years earlier. Toiling under wretched working conditions, as much as 40 percent of the workforce

${ }^{97}$ Paul. Oquist, Violence, Conflict and Politics in Colombia (New York, Toronto, San Francisco: Academic Press, 1980), p. 99.

${ }^{98}$ Gonzalo Sanchez, Ensayos de Historia Social y Política del Siglo XX: Los Bolcheviques del Libano, Las Ligas Campesinas en Colombia, Las Raices Históricas de la Amnistia (Bogota: El Ancora Editores, 1985), p. 53. 
required some hospitalization annually. ${ }^{99}$ In the first four months of 1924 alone, 1023 workers had fallen sick and five died. ${ }^{100}$

The oil workers demanded an eight hour work day, Sundays off, a salary increase of 25 percent and better food at the company's commissary. After a lengthy stalemate followed by government intervention, the workers went back to their jobs without a pay increase. Several of the strike's leaders, including Mahecha, were jailed. The company then proceeded to fire 1,200 persons said to have been associated with the strike. 101

In 1927, the 8000 workers from Tropical Oil at Barrancabermeja again struck for higher wages. Unlike the 1924 debacle, the strike was well organized by Mahecha, who had been released from prison. The government reacted in its usual manner by declaring a "state of siege." Organized labor retaliated by calling secondary strikes throughout the nation's transport sector.

After the company had again repeatedly refused to discuss a wage increase, workers began destroying company railroad tracks and burning company buildings. The government responded by sending troops into the area. During a clash between soldiers and strikers, four workers were killed and three were wounded. ${ }^{102}$ By the end of the strike, 15 workers had lost their lives. ${ }^{103}$ Despite the government's repressive measures, twenty to thirty thousand workers were able to remain on strike for a total of 20 days. In the end however, the government's involvement tipped the scales. The strike was broken without the company yielding concessions, the leaders were again jailed, and this time Mahecha was deported. 104

The bloodiest strike of the 1920's in Colombia was also, as one scholar writes, "the most significant example of Communist failure" in Latin America. ${ }^{105}$ In 1928, workers

\footnotetext{
${ }^{99}$ Hobart Spalding, Organized Labor in Latin America (New York: 1973), p. 66.

100Urutia, Development, p. 95.

${ }^{101}$ Spalding, Organized Labor, p. 67.

${ }^{102}$ Spalding, Organized Labor, p. 67.

${ }^{103}$ Medofilo Medina, La Protesta Urbana, p. 36.

${ }^{104}$ Urrutia, Development, p. 97.

${ }^{105}$ Victor Alba, Politics and the Labor Movement, p. 127.
} 
from United Fruit Company's banana plantations in Santa Marta declared a strike. ${ }^{106}$ The workers were seeking better living conditions and higher wages, but United Fruit refused to negotiate. In 1926, the Third Workers Congress, which was affiliated with the 3rd International, had formed the Partido Socialista Revolucionario _Revolutionary Socialist Party), which had begun to attempt to coordinate the labor movement. ${ }^{107}$ Workers were forced to sign contracts so that they would not be considered full-time permanent employees, and thus not subject to existing labor legislation covering health insurance and accident insurance. United Fruit offered loans to its employees, who lived seven to a 2025 meter quarters, but only in scrip redeemable in the company commissaries where prices were approximately 50 percent higher than in local stores. ${ }^{108}$

When the strike began, the Partido Socialista Revolucionario led by María Cano helped to organize the plantation workers. The party was divided on what the purpose of the strike should be. Raul Mahecha, who had returned from exile, believed that such a large strike, a walkout of over 40,000 workers, should be channelled into a larger insurrectionary movement that could bring about the demise of capitalism in Colombia. ${ }^{109}$ The Party's Executive Committee, however, urged Mahecha "not to confuse the strike with an insurrection." 110

Demands drawn up on October 6, 1928 included the following: the establishment of collective work contracts and abolishing the individual contracts; collective insurance for all of the company's employees; an increase of 50 percent for employees earning less than 100 pesos per month; weekly instead of monthly pay; paid Sundays off and accident indemnification according to Law 76, 1926 and Law 57, 1915; abolition of the company commissaries and their replacement by independent stores; abolition of company loans paid

${ }^{106}$ For a more detailed account of the Santa Marta strike see Confederación Sindical de Trabajadores de Colombia, Bananeras: 1928-1978 (Bogotá: Ediciones Alcaraván, 1978) as well as David Charles Kepner and Jay Henry Soothill., The Banana Empire: A Case of Economic Imperialism (New York.: The Vanguard Press, Inc. 1967), pp. 287-330.

${ }^{107}$ Oquist, Violence, p. 100.

${ }^{108}$ Confederación Sindical de Trabajadores de Colombia (CSTC), Bananeras, pp. 81-83. CSTC provides a detailed account of the events leading up to the strike, including working conditions at United Fruit.

${ }^{109}$ Alba, Politics and the Labor Movement, p. 127.

110 Alba, Politics and the Labor Movement, p. 127. 
in scrip; improvements in sanitary conditions; construction of a hospital for every 400 employees providing sufficient medicines and doctors to provide good health care. ${ }^{111}$

Initially, the government, as well as merchants and independent banana producers throughout the Department of Magdalena were sympathetic toward the strikers. One reason for this attitude was United Fruit's monopoly over the water supply in the region through its extensive irrigation network. Its policy of forcing its employees to purchase their goods at the company store also antagonized the independent merchants of Magdalena. The Minister of Industries states in his Memoria that the "government recognizes the right of private banana producers to industrial independence from the United Fruit Company and should extricate them from the circle of iron which the American company has surrounded them." 112 A government inspector was sent to the scene to attempt to mediate between the two parties. After he had reported that the strike was legal however, he was immediately jailed. 113

The government then heeded a request by United Fruit's management that troops be sent to the region. ${ }^{114}$ On December 6, 4000 strikers held a demonstration at the Ciénaga railroad station. After ordering the crowd to disburse, soldiers fired on the assembled workers and their families with machine guns. During this bloody episode in Colombian history immortalized in Marquez's Cien Años de Soledad, hundreds of civilians were killed, one estimate placing the number as high as 1,500 demonstrators mortally wounded and an additional 400 injured. ${ }^{115}$ Under Mahecha's direction, 12,000 strikers organized in groups, and with captured government arms, waged pitched battles against the army for days. When the fighting ended, at least 1,004 people had died and thousands more had been wounded. ${ }^{116}$ In the aftermath, most of the labor and communist leaders in Colombia were jailed. The government characterized the uprising as the "initiative of Communist

${ }^{111}$ CSTC, Bananeras, pp. 82-83,

112 Oquist, Violence, p. 101.

${ }^{113}$ Oquist, Violence, p. 101.

${ }^{114}$ Spalding, Organized Labor in Latin America, p. 66.

${ }^{115}$ El Espectador placed the count at 150 dead and more than 400 wounded, Rippy, 410 killed and 40 wounded, and Castrillón offers the figure of 1,500 killed. See CSTC, pp 116-117 and Alba, p. 127.

${ }^{116}$ Alba, Politics and the Labor Movement, p. 127. 
revolution." 117 An editorialist justifying the army's actions wrote in the Conservative $E l$ Espectador, "El gobierno tiene elementos de guerra suficientes para hacer una carnicería en la región bananera, y todo parece indicar que no desaprovechará la ocasión, persistentemente buscada, de ensayar sus efectivos militares contra un grupo anárquico de trabajadores rebeldes." 118 In another editorial in El Espectador a few days later, the Communists were blamed for the country's labor problems; "Es casi unánime el concepto de que con la eficaz carnicería de trabajadores que en la zona bananera está haciendo el ejército, va a quedar definitiva y satisfactoriamente eliminado el mal llamado problema del comunismo en Colombia." 119

Commenting on the failure of the strike to achieve the workers' demands, Alba suggests that the Communist leadership had manipulated the entire affair for its own ideological motives:

By making the strike appear to be an insurrection, the Communists isolated it from liberal and socialist support, without which it was doomed from the beginning. But the Colombian Communists were at least able to report their "heroic activity" to Moscow. Months later, at the Communist Conference of Montevideo and Buenos Aires, Mahecha reported on the strike and said: "If we do not make the revolution, it is certain, absolutely certain, that the liberals will." For this Communist fear of competition the Santa Marta strikers paid with their lives. ${ }^{120}$

Despite the failure of the strike to achieve significant results for the laborers of Santa Marta, there is wide-spread agreement that the Conservative government's inept handling of the affair (unleashing the army) served to undermine the Conservative's credibility and ultimately to damage irreparably their chances for re-election in the upcoming elections. ${ }^{121}$

At the same time, it was also a death blow for hopes of an autonomous labor movement. The massacre of the banana zone ultimately would give Gaitán the platform he needed to rise as the champion of labor. In the Congressional debates that questioned the

${ }^{117}$ Oquist, Violence, p. 102.

${ }^{118}$ CSTC, Bananeras, p. 122.

${ }^{119}$ CSTC, Bananeras, p. 122.

${ }^{120}$ Alba, Politics and the Labor Movement, 127.

${ }^{121}$ Oquist, Violence, p. 102 and Urrutia, Development, p. 97, both share this view. 
government's handling of the affair, Gaitán, referring to the United Fruit Company's victory celebration exclaimed, "In those glasses of champagne bubbled the blood and tears of the people." 122

Soon after the strike, membership in the communist-socialist Partido Socialista Revolucionario began to decline as Liberal Enrique Olaya Herrera's campaign gathered steam. ${ }^{123}$ As Fluharty notes, the Colombian Socialist Revolutionary Party had been created by "middle class artisans and the university students." Its orthodox Marxism, in ideology, coupled with its middle class makeup left the bulk of its membership susceptible to overtures from the social reformist wing of the Liberal party. ${ }^{124}$

Although the Communists did not succeed in forging an independent labor movement in the 1920's, Eric J. Hobsbawm notes that "Communism played an analogous role in the formation of the anti-elites of the 1920's, which subsequently became the transforming force of the Liberal Party in the 1930's and 1940's."125 Hobsbawm here refers to the group of "anti-elites" which become known as Los Nuevos which would lead Colombia's liberal new-dealish reform era of the 1930's. With the Conservatives discredited and divided, the decade of the 1930's would increasingly witness the ascent of the Liberal Party as the major protagonist of the labor movement.

\section{DANCE OF THE MILLIONS}

In the 1920's, during a period of spectacular economic growth, the government embarked on a massive public works program to facilitate the expansion of its export economy. Offering relatively high wages, these public projects provided employment for tens of thousands of unskilled wage earners in Colombia's frontier areas. It also meant increased competition for an already scarce supply of labor for the large coffee estates and the plantations of the tropical banana regions. In 1924 alone, the government recruited 14,000 workers for public works projects such as railroads, highways and departmental

${ }^{122}$ Urrutia, Development, p. 107.

${ }^{123}$ Funk Harries, "Camilo Torres," p. 251.

${ }^{124}$ Fluharty, Dance of the Millions, p. 36.

${ }^{125}$ E. J. Hobsbawm, "Ideology and Social Change in Colombia," in Ideology and Social Change in Latin America edited by June Nash, Juan Corradi and Hobart Spalding Ir. (New York, London, Paris: Gordon and Breach Science Publishers Inc., 1977), p. 188. 
projects. ${ }^{126}$ At the height of government expenditures on public works projects in 1928 , between 40,000 and 50,000 workers were employed earning relatively high wages. ${ }^{127}$

A major catalyst of the economic growth of the 1920's was the U.S. indemnification to Colombia for the role it played in the secession of Panama. In addition to the settlement itself, $\$ 25$ million, U.S. private investment in Colombia climbed from $\$ 30$ million in 1920 to $\$ 280$ million in 1929.128 Accompanying this massive influx of foreign capital flowed an additional $\$ 200$ million in foreign credits. ${ }^{129}$ It was during this period, which has become known as the "Dance of the Millions," that the extensive infrastructural improvements undertaken by the government led to the construction of thousands of kilometers of roads and railroads as well as significant improvements in both fluvial and Caribbean port facilities. ${ }^{130}$ Foreign capital was pouring in and the nation's economy was growing. The civil wars were a memory consigned to the past, and an elected civilian government was in power with an active, loyal opposition. Bogotanos proudly referred to their capital as the Athens of Latin America.

The Dance of the Millions accelerated a process of capital accumulation that began slowly with the export of coffee in the closing decades of the nineteenth century and continued, unabated, until the late 1950's, and though slowing after 1960, up until today. The expanding coffee industry, coupled with the Dance of the Millions, helped to cushion Colombia from the harshest effects of the world depression, and prevented political unrest that was common in other countries. Robert Dix accounts for this by citing the lack of élite conflict of interests during the period: "in contrast with most of Latin America, the world depression that began in 1929 did not inaugurate an era of political instability. The fact that Colombia's élites were more unified than conflictual in their goals may partially account for

${ }^{126}$ Zambrano, La Intervención Econónica del Estado, p. 149.

${ }^{127}$ Marco Palacios, Coffee in Colombia, 1850-1970: An Economic,Social and Political History (London, New York, New Rochelle: Cambridge University Press, 1980) estimates 40,000 workers were employed during the zenith of government-sponsored public works programs, the Minister of Public Works in 1929 estimated that 50,000 workers "left their agricultural jobs" to work in the public works projects. The estimate of 30,000 workers is attributed to Alejandro López. (Zambrano, La Intervención Económica del Estado, p. 170).

${ }^{128}$ Oquist, Violence, p. 93.

${ }^{129}$ Oquist, Violence, p. 93.

${ }^{130}$ See Vernon Lee Fluharty's excellent 1957 study for a more detailed account of the "Dance of the Millions." Fluharty, Dance of the Millions: Military Rule and the Social Revolution in Colombia (Pittsburgh: University of Pittsburgh Press, 1957). 
this circumstance; that is, those favoring policies to promote industrial development did not clash fundamentally with landowners, especially those tied to the all-important export trade in coffee. In many cases they were the same people, or closely related. An alliance between the new industrialists and the workers to push aside the landowners therefore did not emerge." 131

The influx of capital, along with high levels of accumulation of domestic capital from the coffee industry led the country to adopt policies favoring rapid industrialization, most notably a program of import substitution. Import substitution was successful in many industries such as textiles: in the period 1927-1928 the local production of textiles for the national market was 19 percent and import comprised 81 percent of the textile market whereas in 1945 the reverse was true; 82 percent of the domestic market's textiles were nationally produced while only 18 percent were imported. ${ }^{132}$ Overall, imports fell from 30 percent of total GNP in 1929 to a mere 10 percent in 1945.133

Although the economy would continue to grow, the period of limitless employment opportunities was to end abruptly with the onset of the 1929 World Depression.

Moreover, at a time when the government was employing between 40-50,000 workers in public works projects, government investment which had reached nearly 70 million pesos in mid-1928; by 1932, public investment had dropped to less than 10 million pesos. ${ }^{134}$ In late 1929 , the official government figures showed 26,700 laborers unemployed, and wages in the public works projects were reduced from $\$ 1.20$ in 1928 to $\$ 0.90$ in late 1929.135 Urrutia offers the figures tallied by labor inspectors in the various departments: 6,000 unemployed in Valle; 5,171 in Bolivar; 5,000 in Caldas; 4,879 in Cundinamarca; 4,176 in Antioquia; 1,000 in Magdalena; and 500 in Choco, a total of 25,726, close to the official

${ }^{131}$ Robert Dix, The Politics of Colombia (New York, Wesport Conn., London: Praeger Publishers, 1987), p. 32.

${ }^{132}$ Kalmanovitz, Economía, p. 302. Kalmanovitz' argument that Colombia's import substitution programs were on the whole very efficient is found on pages $308-315$.

${ }^{133}$ Kalmanovitz, Economia, p. 308.

134Zambrano, La Intervención Económica del Estado, Graph 14, Significance of the Investment in Railroads and Highways Over the Total of National Piblic Investment Expenditures: 1926-1936, p. 171.

135Zambrano, La Intervención Económica del Estado, p. 192. 
totals. ${ }^{136}$. The Journal El trabajador latinoamericano ofiers the probably extremely exaggerated estimate of 150,000 unemployed in Colombia in 1929.137 Although the author was unable to obtain other figures on numbers of workers laid off during the depression, one can be certain that with a seven-fold decrease in government outlays on public works projects, the numbers must have been in the tens of thousands, easing the labor shortage situation in the nation and bringing down wages.

Kalmanovitz argues that despite modest economic growth between 1930-34, there was a "drastic reduction in wages, salaries and overtime" during these years of "vacas flacas." 138 Large numbers of rural laborers had migrated to the cities only to find unemployment along with thousands of construction workers who had been laid off from their jobs in the public works projects. Agricultural production had already begun to decline, and this in turn had led to a sharp increase in prices of basic foodstuffs, creating incentives for individuals to work in the agricultural sector. Thousands of newly unemployed wage laborers from the government programs began to chose the countryside as their destination rather than the city.

The government was attacked on its handling of the economy by the Liberals and the Socialists, particularly its management of the foreign capital that had flowed into the country. In reality, the Conservatives presided over the greatest economic expansion Colombia had ever witnessed. Nevertheless, aided by the negative impact of the depression, Liberals levelled attacks on government corruption, unnecessary foreign borrowing that they argued threatened the ration's solvency, and excessive concessions to foreign companies such as United Fruit that made Colombia little more than a colony.

The Conservative response to the labor unrest of 1929, especially the banana massacre, gave the Liberals another issue which they were able to exploit to great advantage. In 1927, under the pretext of preventing the "communist revolution" from being exported to Colombia from Russia and Mexico, the government had enacted "La Ley Heróica" which placed strict restrictions on individual liberty. La Ley Heróica gave police the right to search the homes of individuals who were suspected of holding communistic

136Urutia, Development, p. 108 . Umutia quotes figures found in El Espectador, October 10, 1929.

${ }^{137}$ El trabajador latinoamericano, Montevideo, No. 26 y 29, (1929), p. 5. Cited in Medofilo Medina, La Protesta Urbana en Colombia en el Siglo Veinte (Bogotá: Ediciones Aurora, 1984), p. 39.

${ }^{138}$ Kalmanovitz, Economia, p. 299. 
ideas and detain them without any warrant from the authorities. ${ }^{139}$ One year later, the Conservative-dominated Senate approved a bill further limiting individual liberty, prohibiting gatherings and associations of groups involved in a long list of unacceptable causes including, bolchevism, communism, prohibiting efforts to foment "attempts" against the constitutional government, to foment "scorn" of the Catholic Church, to support ideas contrary to the institution of the family, to promote ideas against the feelings of loyalty to the nation, to attack the legitimacy of private property, and of consequence to labor, the law prohibited the promotion or support of strikes. ${ }^{140}$ Those convicted of promoting any of these ideas in speeches, letters, or the press were subject to four months to one year in prison. ${ }^{141}$ The laws, along with the aforementioned issues, served to irreparably undermine the credibility of the Conservative government.

\section{THE CONSERVATIVE PARTY FRACTURES}

In late 1929, the Colombian Conservative Party were faced with a national deficit of 32 million pesos, ${ }^{142}$ higher unemployment than the nation had seen in some time, saw itself presiding over a virtual halt in the public works programs, and was viewed by popular opinion as responsible for the bloody massacre in the banana zone. If the situation were not grave enough, the party entered the 1930 elections divided.

Two individuals offered themselves as candidates, Guillermo Valencia and Vásquez Cobo, each with about equal support within the party. As had become commonplace in the Conservative Party, the Catholic Church exercised enormous influence on who the presidential candidate would be. After vacillating for some time, Archbishop Monseñor Perdomo chose one candidate only to change his mind during the ensuing weeks, and once again returning to the original candidate several weeks later. ${ }^{143}$ This was the opening for which the Liberals had hoped. Although the Liberal Party had determined to abstain from participating, events led them to decide to offer a candidate.

${ }^{139}$ Molina, Las Ideas Liberales en Colombia: 1915-1934, p. 176-177.

140Molina, Las Ideas Liberales en Colombia: 1915-1934, on pages 178-179 is found the text of the proposed legislation. The Liberal minority unanimously rejected the law. The text of their objections appears on pp. 184-186. The law was passed by the Conservative majority.

${ }^{141}$ Molina, Las Ideas Liberales en Colombia: 1915-1934, p. 179.

142Zambrano, La Intervención Económica del Estado, p. 212.

${ }^{143}$ Urrutia, Development, p. 114. 
The party decided on Dr. Enrique Olaya Herrera, an aristocrat, and a venerable member of the oligarchy. Moderate Conservatives had also approached Dr. Olaya, and the new candidate headed a government that would be called the Concentración Nacional. Though the Conservatives would have preferred to win the elections, Olaya Herrera was a moderate that was acceptable to both parties' moderates. Many Conservatives and conservative Liberals alike were worried about a new radical, violent tendency they perceived among the working class. Colombian historian Antonio García comments on this preoccupation:

The oligarchies of both parties felt the foundations of their republic shake beneath them, and in the face of the horror of revolutionary uprisings, took advantage of the union created by the Conservative split and the disconcerting schism within the Church, to present to the country a new road: that of National Concentration....and Olaya Herrera, a representative figure of opportunist, ideal-poor republicanism... National Concentration was a tactical maneuver to avoid revolutionary explosions, by transferring power to a Liberal chief of the privileged classes. While the ingenious Liberal public told itself that in Olaya's election it had found a tactical road toward the new revolutionary order...falling victim to that amnesia so frequent in our history...the upper classes, both Liberal and Conservative, had saved their dynastic kingdom by an able maneuver. ${ }^{144}$

Whether or not Garcia's conclusions are accurate, the moderate reforms undertaken by the Olaya administration heralded even greater changes that would be affected under the more progressive government of López Pumarejo. For labor, the change from

Conservative to Liberal rule would mean increased protection and support from the central government. It also meant that labor would not forge an independent "third way," to become an autonomous force for change in society. Instead, labor would hitch its star to the fate of the Liberal Party.

\section{CONCLUSION}

In the first decades of the twentieth century, Colombia embarked upon a period of rapid industrialization made possible by the installed capacity created by the coffee boom in the closing years of the nineteenth century. The $\$ 25$ million Panama settlement was followed by a massive influx of U.S. and other foreign capital, the Dance of the Millions, which played a major role in Colombia's drive towards industrialization. The period witnessed rapid growth of industry, improvement of transport links, and the creation of 
massive public works programs. In turn, the nation began to experience accelerated demographic change and population growth, especially among the nation's departmental capitals. Employment opportunities in the growing industries of the urban areas created new channels of socio-economic mobility. A distinct wage-earning, working class was to emerge in the first decades of the century: that class has continued to increase steadily in numbers through the present day. Over time, segments of this working class have developed an evolving consciousness of their distinctness as a group with interests separate from other major social groups in Colombia such as artisans, industrialists, and the commercial élite. Although this consciousness has often translated into isolated struggles (such as single-factory or single sector strikes) of groups of workers to achieve economic goals, rarely has it involved concerted actions by large segments of the working class: outside the tiny, post-1930 Communist Party primarily led by intellectuals rather than workers, never did this consciousness translate into proletarian revolutionary urges.

Early on in the century, a confusing array of "workers" groups arose which generally included artisans, wage earners, and industrialists. Early organizations of artisans, workers and intellectuals, such as the Worker's Party, strove to distance themselves from the traditional parties. Though it had been created with the strong backing of Uribista Liberals, by 1909 the Worker's Party sought to carve an independent path for industrialists and workers.

Shortly after the party had determined to pursue a path independent of the established parties, it was pulled into backing the Republicans who held moderately proworker stances and possessed more electoral clout than the new party. The other major labor group which had been recently created, the UNIO, also committed to an independent stance, supported the Liberals. "Groups such as the UNIO," Sowell comments, "posited that if a united industrialist/worker political front could be formed, then it could bring about the reforms necessary to make the "system" more responsive to their will and needs. Ideally, members of the UNIO hoped, such a movement was to be independent of the established parties, but reality dictated relations with Republicans and Liberals, compromises not dissimilar to those made earlier by artisans." 145 Like the artisans of the second half of the nineteenth century, the new unions chose a path of cooperation rather than confrontation, bowing to the traditional electoral strength of the established parties in an effort to obtain tangible economic gains for their constituents. The offer of working class and artisan support was contingent upon the established party's promise of support

${ }^{145}$ Sowell, "The Early Latin American Labor Movement," pp. 341-42. 
for labor candidates and social and economic policies that would help improve the lot of its members. To the leadership of the new labor organizations, this strategy seemed the most rational path for obtaining benefits for workers and artisans.

The Unión Obrera Colombiana was the first modern labor organization that limited its membership to proletarians and artisans, excluding from its ranks industrialists which had formed part of the earlier organizations. Although it too fell victim to partisan politics in an effort to win pro-worker supporters through coalitions at the ballot box, its original, worker-created platform called for a literacy campaign and public education for workers, protection of national industries, increased wages and a clause to stop exploitation of workers.

Anarchist influence was also apparent early in the century, though its reach was limited almost exclusively to Colombian ports, railroads and rivers. The anarchists were a radical influence on workers in these sectors, their short-lived impact most apparent in organization of banana and oil workers and particularly pronounced in early strike organization. Eventually, the anarchist influence was replaced by better organized, more consistent Liberal, Socialist and Communist efforts to organize workers.

The 1916 Partido Obrero and its independent successor, the Socialist Party of Colombia created the same year, held a more conflictual view of society than had their predecessors, recognizing two dominant classes in society, workers and consumers. The Socialists recognized the Liberal Party as its chief competitor for the minds of the working class. Socialists were however, also open to creating pragmatic alliances with candidates from other parties who supported concrete reforms that could advance workers' interests.

Between 1919 and 1929, a number of strikes took place, making the strike a common labor method of obtaining economic benefits. Many of the strikes were successful in achieving worker demands, despite often being accompanied by violence. The strikes were generally spearheaded by communist, socialist or anarchist organizers, and were only applauded by mainstream Liberals if they were not accompanied by violent protest and destruction of property.

The new Socialist Party soon began to be perceived as a threat to many Liberals who could not understand why workers would turn away from the party that truly responded to their interests, the Liberal Party. Strong electoral performances by socialist candidates in 1919 alarmed Liberals who in some areas such as Antioquia, actually received fewer votes than the Socialists. The Socialists' organizational efforts and leadership role in strike activities aimed at obtaining concrete benefits, made it the first independent movement representing workers' interests that actually worked. 
There can be no doubt that the scores of pro-Socialist newspapers, successful organizational efforts and a moderate, non-revolutionary ideology more palatable to socially conservative artisans and a probable majority of the nation's workers, helped to forge a new working class consciousness. This new consciousness was observable in workers' demands for better health care and higher wages and the demand for other segments of society to recognize workers' value as the nation's producers, demands similar to those made by artisans in the 1860's, 70's and 80's. Even though the Party was coopted by the left wing of the Liberal Party after 1924, it had succeeded in establishing numerous artisan and industrial labor unions, a left-leaning, pro-worker press, and had led a number of successful strikes.

Why then were many of the party's supporters were willing to abandon the Socialist Party in 1922 to support the Liberal cause? To most, it seemed that 1922 could actually bring a strong pro-labor Liberal candidate to the presidency. Since the Socialists never created an ideology that differed profoundly from the welfare-oriented, left wing of the Liberal Party, ${ }^{146}$ Benjamín Herrera was sufficiently reformist to appeal to most Socialists, drawing them into an anti-Conservative coalition.

Another reason the Liberals were able to coopt the Socialists so quickly was the reigning Conservative government's hostility to labor. Conservative governments violently suppressed a number of strikes and made no secret of their mistrust of working class organizations. Moreover, the Conservatives were vociferously anti-communist, often not pausing to make fine distinctions between the reformist, moderate Socialist Party of Colombia and the more radical communism of Lenin's Soviet Union. Socialist intellectuals, artisans and workers alike were willing to return to the party which had traditionally espoused equality, brotherhood, and social change.

What these groups chose to downplay or ignore was the fact that liberalism's traditional proponents had promoted laissez-faire economic policies which had generally had the effect of undermining workers' interests throughout the second half of the nineteenth century. Moreover, abandoning an independent course for workers organization

146It must be kept in mind that the platform drawn up at the Liberal Convention in Ibagué in 1922 was very similar to the platform developed at the Socialist Convention of Honda in 1920. Although the Socialist Party was dissolved in 1925, a new party was created in 1926 by Ignacio Torres Giraldo, Maria Cano (known as the Red Virgin of the Colombian proletariat), Raúl Mahecha, and Tomás Uribe Márquez, that would eventually become the Colombian Communist Party of 1930. Although the new party would not become a major catalyst for working class organization, it would be very active in organizing peasants in one important coffee region in Colombia, Tolima as well as petroleum workers. As was mentioned, the Communists also played a role in organizing the violent 1928 United Fruit strike of banana workers. 
created a reliance on the goodwill and favor of the élites who controlled the Liberal Party. Although it was true that the party was currently embracing ideas and advocating positions that favored the well-being of laborers, who could guarantee that the party would continue to follow this path? Could not élite Liberal Party leaders begin to exploit the subservient condition of labor to further their own goals, while offering just enough tangible economic benefits to workers to guarantee their electoral support, much as they had done with the democratic rhetoric of equality, democratic reforms and brotherhood they had used to sway the artisans in the last century?

Colombia was passing through a forty-five year period of civil peace, with a functioning democratic electoral system. What if the nation were to return to the bloody civil wars of the nineteenth century that pitted Liberals against Conservatives, to the victor going the spoils of government? Under such a scenario, Conservative-dominated governments unchallenged by a loyal Liberal opposition would likely repress labor. This possibility seemed very remote to socialist leaders in 1924 . The defecting Socialists took a calculated risk that at the time seemed to be a rational decision.

The Socialists-turned-Liberals looked to the example of Uribe Uribe, certain that his state-intervention, welfare-oriented, strong pro-working class stances were the ascendent primary concerns of a modernizing Liberal Party. In this belief, they were largely correct. While the general concept of free markets and international trade remained important interests of the Liberal Party, the party began to concern itself more with nurturing domestic industry, protecting workers' rights, and generally improving the standard of living for Colombia's masses. In the 1930's, laissez-faire was replaced by stateintervention as the Liberals' rallying standard to be applied to the economic and social life of the nation.

What happened to socialism in the early 1920 's in Colombia was not a simple matter of cooptation by a more moderate Liberal Party. The Socialists themselves had a profound impact on socializing the Liberal agenda. Moreover, the Socialists' defection eventually would tip the scales in favor of the radical wing of the Liberal Party, helping it to become the dominant force in the party's political and social orientation. It made sense for the Socialists to tum to an historically established party which had a solid electoral base and which now seemed to be embracing the very same beliefs they themselves professed.

Given the benefit of historical retrospect, the question we now must address is how much influence workers and socialists had in molding modern Liberal ideology? How did that modernization translate into support for labor's goals? Did the trust vested in the Liberal party by those who had previously supported an independent party to forego an 
independent Labor movement reap tangible benefits for workers? These questions are addressed in Chapter Seven. 


\section{CHAPTER 7}

\section{LABOR AND THE LIBERAL REVOLUCIÓN EN MARCHA}

...nuestra política es revolucionaria sin ser marxista, ni clasista, pero en modo alguno pretende desconocer el orden social existente. No conspira contra el capital, ni espera la oportunidad para quebrantar la propiedad privada y entregar las fábricas a los obreros y las haciendas a los campesinos.

\section{Alfonso López Pumarejo, Obras Selectas ${ }^{1}$}

We were born Spanish.... We speak the tongue of Castile because we can speak no other... The twenty cowardly governments [of Latin America] have put themselves into the hands of foreign nations, dedicated to false liberalism and to masonic, atheistic democracy....The panorama is desolate.... We are still conquered territory...

Hispanoamérica, the land of vassalage.... Each day the yoke of Saxo-Americana is drawn tighter around our throats. Sometimes the yoke is of steel, sometimes of silk, soft and perfidious...

But-all is not lost. There is still heard the voice of Laureano Gómez to tell the truth about the future, to direct us to the road of tomorrow, the Catholic Hispanic Empire. And we will go back to Spain.

\section{Camacho Montoya praising Laureano Gómez from the pages of El Siglo ${ }^{2}$}

The exceptional strength of Colombia's traditional élite-led political parties and their ability to successfully coopt more radical forms of workers' organizations inhibited the development of working class cultural and organizational solidarity and autonomy. The current chapter explores the evolving relationships between the left and moderate wings of the Liberal Party, socialist and communist organizations, and organized labor.

\section{LOS NUEVOS, SOCIALISM, AND A NEW IDEOLOGICAL ORIENTATION}

Inspired by the ideals of Uribe Uribe, in the 1920's several young intellectuals began to question both traditional Liberal solutions to the nation's problems (laissez-faire economics) as well as the predominant ideological focal point of the Conservatives (Hispanic Catholicism). In the poetry and prose of Los Nuevos, the group wrote about

${ }^{1}$ López Obras Selectas, T XI, p. 160 cited in Alvaro Tirado Mejía, "Algunos Aspectos del Pensamiento de López Pumarejo," Revista Universidad de Medellin, Medellín: Editorial Lealon, Vol. 49, (May, 1986), pp. 164-165.

${ }^{2}$ Quoted in Vernon Lee Fluharty, Dance of the Millions, Militry Rule and the Social Revolution in Colombia 1930-1956 (Pittsburgh: University of Pittsburgh Press, 1966), p. 63. 
"everyday life and common language" in an attempt to try to understand themselves, their era and their society. ${ }^{3}$ Comprised of such young intellectuals as Luis Tejada, Gabriel Turbay, Lleras Restrepo, Alberto Lleras Camargo and Jorge Eliécer Gaitán, Los Nuevos were profoundly influenced by socialist ideas in their youth and many later rose to preeminence within the ranks of the Liberal Party.

Although Socialist Clubs had existed in Colombia as early as 1849 , socialist thought in the country did not become a major force until the 1920's. The socialist ideas that reached Colombia via Barcelona, were inspired by the socialist writings of the idealists Luis Tejada and Luis Vidoles. ${ }^{4}$ This socialist influence in the labor movement, particularly among Los Nuevos helped shape the ideological development of the modern Liberal Party.

The other major influence on the thought of Los Nuevos was Uribe Uribe, primarily in his advocacy of state intervention to enhance the welfare of the nation's poor, his idea of "State Socialism." As early as 1904 Uribe Uribe had written:

Solo el Estado, que es perpetuo, representa los intereses perpetuos de la sociedad; sólo él puede hacer desembolsos reproductivos a través de los años; sólo él puede, con larga visión, imponer sacrificios a las generaciones actuales para preparar a las venideras una existencia mejor. En nuestra Colombia, sólo el esfuerzo colectivo, bien dirigido y honradamente manejado, puede sacarnos de la postración, presente para convertimos en lo que debemos ser: un pueblo rico, grande y glorioso, el primero en Hispanoamérica." 5

Uribe also proposed other legislation that helped to make him popular with the "new generation" such as indemnification for accidents in the workplace, workers' disability pay, healthier working conditions, public assistance, obligatory education, free medical care and legal service for the poor, construction of popular theaters, music halls, libraries and museums, profit sharing, protection of industries, low-interest loans from the government for workers and campesinos, cooperatives and a limit on the rights of inheritance for the rich. ${ }^{6}$ Most of Los Nuevos, like Uribe Uribe, also stopped short of

\footnotetext{
${ }^{3}$ Kalmanovitz, Economia, p. 267.

${ }^{4}$ Victor Alba, Politics and the Labor Movement in Latin America (Stanford, California: Stanford University Press, 1968), p.106.

${ }^{5}$ Gerardo Molina, Las Ideas Liberales en Colombia, 1915-1934 (Bogotá, Colombia: Ediciones Tercer Mundo, 1982), p. 183.

${ }^{6}$ Gerardo Molina, Las Ideas Liberales en Colombia, 1915-1934, pp. 185-86.
} 
supporting what he had disparagingly termed "street socialism," efforts to abolish private property.

Although many Liberals such as Alberto Lleras Camargo, a future president of the republic, believed that major reforms along such lines would improve the living conditions of Colombian agricultural workers and laborers, nearly all of them also believed that reform of the existing democratic system could affect the needed change while maintaining the social system intact. While striving to support labor by openly pressing many of its demands to the Conservative government, most Liberal élites were actually seeking allies and electoral support: from the beginning, they wished to funnel and control labor rather than work as an equal partner. Labor's aspirations could in their view, and in the view of many labor activists, most effectively be asserted through the Liberal Party. An independent party representing working class interests was unnecessary.

When the Liberals finally came to power, they institutionalized this sentiment by passing legislation that included an article that prohibited workers' groups from engaging in independent political activities: "A los sindicatos les está prohibida cualquier ingerencia directa o indirecta en la política militante del país. La contravención a lo dispuesto en éste artículo tendrá como sanción la disolución inmediata del sindicato, previo concepto del Ministerio Público, y será decretada por la Oficina General del Trabajo."7 This legislation, and the later insistence of the last Liberal government before the terrible onslaught of la Violencia, the administration of Alberto Lleras Camargo, to enforce it, is the most visible of the Liberal Party's effort to control labor.

Legislating control of the process regulating relations between labor and capital effectively limited political participation by labor to the two traditional parties. Liberals certainly held an advantage as a result of their social-welfarist orientation. The Liberal government's control of the labor movement also definitively ended earlier bids by groups such as the old Republican party and the Socialist Party to play major roles in the organization of workers. Such competition had concerned Liberal leaders who believed that urban workers were a natural constituency. In the second decade of the century, Liberal leaders were correct in this assumption. By the elections of 1921, the Liberals had become justifiably alarmed by the successes of the Socialists. In an editorial in $E l$ Espectador, a Liberal leader commented: "It is necessary that the Socialists understand that since the Conservative Party is presently the only obstacle to the initiation of social reform,

${ }^{7}$ Article 23, Law 83. Quoted in Gómez Támara, "La intervención de los sindicatos en la política," Revista Universidad de Antioquia, (1945), p. 519. 
only by helping to defeat it through a successful campaign by a unified Liberalism, is one really working to further the interests of the people."8

In October of 1921, the Socialists ran their own candidates in municipal elections. The success of the competition, writes Urrutia, "was instrumental in bringing about a radical change in the ideology of the Liberal Party at the party convention later in the month." Contemporary José Mar wrote:

In its convention the Liberal Party adopted the moderate and viable socialist ideas....In view of this fact, the modest reforms for which our serious socialist groups have been aspiring come under the most efficient sponsorship--that of the Liberal Party, which advocates a new ideology and has abandoned the old individualist doctrines....In view of this new attitude, completely new, and logically divorced from ineffective individualism, the Liberal forces shall be strengthened on the one hand, and on the other hand will be forced to advocate the reforms for which the small and enthusiastic socialist groups have valiantly fought. 9

José Mar correctly assessed what was happening within the ranks of the Liberal Party: a perceptible shift away from the classical liberalism of Bentham, Locke, and Adam Smith towards modern, or welfare liberalism which advocated a more interventionist government stance in efforts to secure the general welfare of the nation's citizenry.

Seeking socialist support, Liberal presidential candidate Benjamín Herrera wrote in a letter to the executive committee of the Socialist Party, "it is within the Liberal Party that the groups which favor socialist organization can work with the greatest hope of success and achieve the reforms which would improve the living standard of the masses." 10 During the months following the elections, the Liberal Party began to admit young Socialist intellectuals, including Gaitán. In 1924 Gaitán wrote the following about the Liberal Party:

It is not by destroying the political tendency that in Colombia represents the opposition and progressive party that one works best for the triumph of the reforms that the people wish; we believe that it is better to fight so that the progressive forces of Colombia inscribe on their banners the new ideas, and so that they make their own the

${ }^{8}$ Richard Funk Harries, "Camilo Torres," p. 247.

${ }^{9}$ Miguel Urrutia, Development of the Colombian Labor Movement, pp. 74-75.

${ }^{10}$ W. O. Galbraith, Colombia: A General Survey (Oxford University Press, 1966), p. 144. Quoted in Funk Harries, "Camilo Torres," p. 248. 
battle for the welfare of the proletariat and for the necessary vindication of the serfs of capital."

The political realization that the Liberal party faced a bona fide threat from the Socialists coupled with the chorus of influential voices of the party's ascendent leaders from Los Nuevos whose ideological outlook had much more in common with the British Fabians and Keynes than with Adam Smith, helped to move the party's focus to the left. The rhetoric of the left wing of the Liberal party helped it capture the votes, if not the complete trust, of most workers:

\begin{abstract}
Antes de caer la metafórica hegemonía, cuando se vivía bajo eol imperio de un reaccionarismo elemental, palpibaban en el subsuelo político una multitutd de grupos revolucionarios, en su mayor parte extremistas, y entre los cuales hallábase la flor de la juventud anticonservadora de aquellos tiempos. El espíritu revolucionario no podía traducirse sino en actividades clandestinas, condenadas y perseguidas por el monótono celo de los mantenedores del orden de cosas existente. Por fuera de aquellos esquivos núcleos juveniles reinaba el horizonte conservador en todas las latitudes. La esfera ideológica de la nación giraba sobre los dos polos de la extrema derecha, cristalizada en el gobierno y en sus hombres, y de la extrema izquierda, donde las inteligencias puras de Gabriel Turbay, José Mar, Luis Tejada, Moisés Prieto y otros tan buenos se habían atrincherado, desoladas, rebeldes, en el marxismo de la Tercera Internacional. ${ }^{12}$
\end{abstract}

Even during the Liberal Party's political shift toward more active government involvement in social welfare issues such as creating a system of social security and supporting labor legislation that provided safeguards for laborers, mainstream Liberal thought and actions remained firmly planted within the boundaries of the existing political, economic and social system. Mainstream liberalism in Colombia in the 1930's sought not to forge a new society based on socialist principles, but rather to reform the existing system to make it more responsive to the needs of the pueblo. To labor, the message of the Liberal party was clear: Colombian liberalism is pledged to advance the material cause of workers. In view of its historical electoral strength, the Liberal party seemed the only reasonable choice for laborers who wished to see the defeat of a Conservative government which held an antagonistic stance towards workers and the labor movement. Liberalism's message

\footnotetext{
${ }^{11}$ Miguel Urutia, Development, p. 79.

${ }^{12}$ Acción Liberal, No. 40, 1936, p.29. Quoted in Gonzalo Sánchez, Ensayos de historia social y politica del siglo XX, (Bogotá: Ancora, 1984), p. 57.
} 
was seductive. The decade of the 1930's witnessed the virtual absorption of labor into the Liberal camp. In the process, the Liberal party coopted the creation of an autonomous labor movement and preempted the articulation of an independent workers' voice in society's affairs.

\section{THE RURAL PROTEST: SMALLHOLDER STRUGGLES TO ACQUIRE LAND TITLES}

The 1920's and 1930's witnessed a period of agrarian unrest as conflicts erupted in foreign enclaves such as fruit and oil and between hacendados eager to expand their landholdings in the new territories and peasant colonos. One reason for this timing argues historian Erich Hobsbawm, was that at the beginning of the twentieth century a peasant consciousness began to emerge. In addition to Gaitán's Union Nacional Izquierdista Revolucionaria (UNIR) and the Colombian Communist Party, anarcho-syndicalist groups such as the group led by Juan de Dios Romero, the Movimiento Agrario del Sumapaz, as well as the smaller Partido Agrario Nacional (PAN) began to press for agrarian reform. ${ }^{13}$ Hobsbawm maintains that the collapse of the international primary products market in 1929 aggravated what had already become an acute social crisis: "Foreign-owned enterprise such as United Fruit provided a natural spark-plug for explosion, though its significance in the Colombian economy at the time was limited." 14 As has been alluded to previously, communists, and with much greater success, liberals began to attempt to organize rural workers. In foreign enclaves, particularly the fruit companies, the communists played a role in organizing workers, such as in the 1928 Santa Marta strike.

Despite concerted efforts by communist leaders to organize peasants, communists met with little organizational success in the countryside. There conflicts largely arose from disputes between individual peasants or between peasants and large landowners over land claims. Since land disputes frequently involved individual colonos seeking to better their own conditions by owning their own means of production, and since many disputes pitted one colono against another, in most cases these individuals did not easily lend themselves to concerted, cooperative action.

${ }^{13} \mathrm{~A}$ good discussion of the ideological differences of each of these groups can be found in Gonzalo Sánchez's excellent essay, "Las ligas campesinas en Colombia", in Ensayos de historia social y política del siglo XX, (Bogotá: Ancora, 1984).

${ }^{14}$ Eric Hobsbawm, "Ideology and Social Change in Colombia," in Ideology and Social Change in Latin America, edited by June Nash, Juan Corradi and Hobart Spalding Ir. (New York, London, Paris: Gordon and Breach Science Publishers Inc., 1977), p. 193. 
The Russian Revolution had exerted a special attraction for the far left wing of the labor movement as early as 1924 . Fluharty notes that Colombian Communists were active in the creation of the Latin America Confederation of Unions (CSLA), which exerted a strong influence on labor throughout the continent between 1924 and 1934. 15 The appeal of communism was strengthened by intellectuals, such as Raul Mahecha, who brought ideas from the international labor conferences held in Moscow in 1927 and 1928 to Colombia. ${ }^{16}$

The ideological differences among the small number of leftists who did not defect to liberal ranks, adherents to the new Communist Party, as to the type of support and resources that should be dedicated to organizing peasants rather than proletarians also helped to stifle a more concerted organizational effort. As Fluharty notes, the Communist Party in Colombia "came from the unrest of middle class artisans and the university students. It was orthodox Marxist in theory, but the peasants and workers knew it not, and its intellectual adherents later veered away into the Socialist party and the reformist wing of the Liberal party." 17 Bergquist in his Labor in Latin America also alludes to the communists' failure to capitalize on their early successes organizing peasants as a result of ideological blinders: "It is a curious fact that the Colombian Communist Party, officially formed in 1930, complained to the International in 1935 that its membership was insufficiently proletarian, being composed primarily of peasants and Indians, rather than workers (International Press Correspondence 1935: 1348)"18 Although active in organizing a national coffee strike in late 1934 and early 1935 and enjoying limited success with the ligas campesinas, the Communists had waited too long to begin efforts to organize rural laborers. The following year the Communist Party made a fateful decision to enter into a direct alliance with the Liberal government.

In addition to the ideological reasons impeding effective early organization of rural workers by the Communists (proletarians, not peasants are the driving force of history in the Marxist paradigm), tactical errors were made based on misinterpretations of Colombian socio-economic realities. Even after the 1928 United Fruit strike had failed to generate a revolutionary movement and had led to the ensuing carnage at Ciénaga, in an address to the

${ }^{15}$ Fluharty, Dance of the Millions, p. 36.

${ }^{16}$ Fluharty, Dance of the Millions, p. 36.

${ }^{17}$ Fluharty, Dance of the Millions, p. 36.

18 Bergquist, Labor, p. 194. 
Socialist Revolutionary Party of Colombia (PSR) in February 1929, the Third Communist International still hinted that conditions were nearly ripe for a massive insurrection directed at the major expressions of "imperialism", the U.S. fruit companies; "Existen, pues, en Colombia, -se afirmaba-todos los signos de una crisis económica, financiera y política próxima." 19 Many in the PSR interpreted Moscow's message to mean that large-scale strikes could be channelled and converted into a broad scale revolutionary movement, despite their experience of the dismal failure of the 1928 strike to generate anything even proximating revolution. In the process of forging a social revolution from massive strike activities, socialist leadership hoped to employ the same strategy Liberals were to adapt so successfully in the immediate future: coopt and absorb liberal elements into the struggle. Once the battle lines had been drawn the Communists believed, many liberals would be absorbed into the movement, liberals who "were really revolutionaries in the popular and democratic sense, or who could evolve in such a way, in the heat of the revolutionary movement of the masses." 20 The Communists failed to attract left-wing liberals to their cause. They also failed to ignite social revolution.

It would at first glance seem that the coffee sector might be fertile grounds for leftleaning organizers, especially given the numerous struggles between powerful landowners and poor colonos. Coffee supported a substantial portion of the Colombian workforce: estimates range from between 500,000 to one million workers engaged in full-time or harvest-work in coffee production, the latter figure representing nearly one eighth the entire population of Colombia in the late 1920's. ${ }^{21}$ Between 1905 and 1920, coffee exports expanded from just over one-half million 60 kilo sacks with a value of slightly more than five million pesos to approximately two million sacks in 1925 with a value of more than 65 million pesos. (See table 7:1)

Another factor favoring communist organizers was the depression. The onset of the depression and the downsizing of public works projects created a new pool of unemployed rural laborers. Urrutia notes that these workers helped to "radicalize" rural protests:

${ }^{19}$ Message from the Communist International to the Socialist Revolutionary Party of Colombia, Moscow, February 1929 cited in Gonzalo Sánchez, Ensayos, pp. 68-70.

${ }^{20}$ Ignacio Torres Giraldo, Los inconformes, (vol. 4, Editorial Margen Izquierdo, Bogotá, 1974), p. 48.

${ }^{21}$ Bergquist, Labor, pp. 332-333. 
The men who had been in contact with the anarchist labor organizations in the oil fields, the banana zone, and among the railroad and dock workers refused to accept the archaic tenant landlord relationship of the Colombian latifundia. With the help of communist agitators, the peasants formed leagues in Cundinamarca, Tolima, and Valle, and attempted to obtain the right to their own land. In same cases they invaded uncultivated haciendas and defended their newly acquired land by force of arms. ${ }^{22}$

\section{TABLE 7:1}

Colombian Coffee Exports 1900-1925

Volume and Value

\begin{tabular}{lcc}
\hline Year & $\begin{array}{c}\text { Exports (sacks } \\
\text { of 60 kilos) }\end{array}$ & $\begin{array}{l}\text { Value (Col. } \\
\text { Pesos) }\end{array}$ \\
\hline & & \\
$1900-4$ & $\ldots 00,811$ & $5,036,240$ \\
1905 & 5036,005 & $6,131,760$ \\
1906 & 568,377 & $5,338,273$ \\
1907 & 606,749 & $5,549,064$ \\
1908 & 707,020 & $6,346,952$ \\
1909 & 570,011 & $5,517,408$ \\
1910 & 631,666 & $9,475,448$ \\
1911 & 932,222 & $16,777,908$ \\
1912 & $1,020,741$ & $18,369,768$ \\
1913 & $1,032,136$ & $16,098,185$ \\
1914 & $1,129,849$ & $18,278,631$ \\
1915 & $1,211,145$ & $15,996,031$ \\
1916 & $1,047,394$ & $17,651,569$ \\
1917 & $1,148,840$ & $20,675,023$ \\
1918 & $1,684,107$ & $54,291,638$ \\
1919 & $1,443,947$ & $36,328,333$ \\
1920 & $2,345,595$ & $41,945,052$ \\
1921 & $1,764,823$ & $36,291,812$ \\
1922 & $2,060,658$ & $45,088,906$ \\
1923 & $2,215,824$ & $68,793,353$ \\
1924 & $1,946,730$ & $66,524,056$ \\
1925 & 1,705 &
\end{tabular}

Source: Charles Bergquist, Coffee and Conflict, Table 10:1, p. 255.

One area where socialist and communist organizers in fact enjoyed modest success was in the support they extended to the peasant leagues, las ligas campesinas, most involving coffee workers. In order to stimulate agricultural production, which had continued to decline since 1929, the Liberal governments of the 1930's had decided it was necessary to adopt a more positive stance toward the nation's small-holders. Law 83 of

\footnotetext{
${ }^{22}$ Urrutia, Development, p.130.
} 
1931 gave labor groups the right to organize. ${ }^{23}$ Law 200 of 1936 sought to provide de jure recognition of colono and peasant land claims, voiding titles if original deeds could not be produced by landholders.

By the early 1930's, several peasant leagues and been organized and had successfully carried out land invasions. Both Jorge Eliécer Gaitán's UNIR and the Partido Comunista de Colombia (PCC) helped to organize successful land occupations by peasants. ${ }^{24}$ Though Gaitánismo appealed more powerfully to the urban poor than in the countryside, there is some evidence that the great populist demagogue made a significant impact among the peasantry." 25 Famous among the PCC's efforts was the 1925-1929 organizing campaign of the Red Flower, María Cano, poet and daughter of a Liberal family in Medellín who owned an important newspaper. ${ }^{26}$

Ideologically, the peasant leagues drew inspiration from the pens and pamphlets of leftist leaders, many of whom were artisans. In places such as in the rural coffee municipio el Líbano, in northern Tolima, the "bolcheviques del Líbano" received strong grass-roots support from artisans.

One such individual was the radical publicist Jorge Ferreira who worked and wrote in el Líbano. In his Testamento del Diablo in 1931, he deplores the vicious cycle of indebtedness of the arrendatarios:

$$
\begin{gathered}
\text { ¿Qué le queda al cafetero } \\
\text { de tántas angustias, ¿tíntas? } \\
\text { deudas, males y recuentos } \\
\text { de la cosecha que pasa } \\
\text { por eso voy a donarle } \\
\text { una remota esperanza } \\
\text { de otra que se aproxima } \\
\text { que será la que lo salva; } \\
\text { lo dejo mis ilusiones } \\
\text { y mis cuentas problemáticas } \\
\text { para que llegue pensando } \\
\text { al final de la jornada llevando entre su morral } \\
\text { un puñado de esperanzas: }
\end{gathered}
$$

${ }^{23}$ Urrutia, Development, p. 118.

${ }^{24}$ Paul. Oquist, Violence, Conflict and Politics in Colombia, pp. 96-97.

${ }^{25}$ Hobsbawm, "Ideology," p. 195.

${ }^{26}$ An excellent, contemporary source on the organizational efforts of the Communist Party, UNIR and other socialist organizations is Gonzalo Sánchez's collection of essays Ensayos de historia social y política del siglo XX (Bogotá: Ancora, 1984). 
tisis, paludismo, anemia

y hasta el alma hipotecada. ${ }^{27}$

An insurgency in el Líbano led by radical artisans which attempted to seize state power in 1929 , was defeated by Colombian militia, police, and army units. ${ }^{28}$

One of the most famous examples of successful invasions of haciendas was the Colonia Agrícola de Sumapaz in Cundinamarca. Over 6000 peasants successfully returned to this area, claiming that it had been illegally taken from them. ${ }^{29}$ Other invasions elsewhere in Cundinamarca and Tolima also proved successful.

Communist and UNIR organizational efforts helped to serve as catalysts to action among coffee smallholders in instances when a large number of squatters, invasores, or legitimate owners who had been robbed of their land through enclosures, sought to press their claims against one or two landowners who were resisting their efforts to occupy or gain title to the land. Here socialist ideals and organizational skills, consistent with the felt needs of the farmers, were able to mobilize rural workers to resist landholder efforts to expel peasants and help them to press their own claims to title for the land.

Throughout the 1930's, the government was active in solving disputes that would arise from landowner - squatter conflicts. The general course of action under Liberal governments was to buy the occupied land form the landowner and then sell it back to the peasants on credit. At times, the government declared the invaded land national land, and gave the squatters legal title. Even in one of the earliest areas of Spanish colonization in the nation, Cundinamarca, the total number of coffee farms notably increased in the 1930's, strongly suggesting that Liberal reforms coupled with local activism yielded some positive results, at least in terms of returning formerly owned lands that had been enclosed by powerful landholders. Table 7:2 gives some idea of the effect the division of haciendas had on the numbers of coffee farms in Cundinamarca during this period.

${ }^{27}$ Colorado (pseudonym of Jorge Ferreira) in El Testumento del Diablo, Tipografía Libano, August 1931 quoted in Gonzalo Sánchez, "Los holcheviques del Líbano," Ensayos de historia social y política del siglo XX (Bogotá: Ancora, 1984), pp. 48-49.

${ }^{28}$ Gonzalo Sánchez, in "Los bolcheviques," discusses this event in detail in chapter four.

29 Catherine LeGrand, "Labor Acquisition and Social Conflict on the Colombian Frontier, 1850-1936,"

Latin American Studies, Vol. 16, (1985), p. 46. 
TABLE 7:2

Cundinamarca's Coffee Farms in 1932 and 1940

Year Number of Farms Production in 60-kilo Sacks

$1932 \quad 33,812 \quad 364,379$

$1940 \quad 30,270 \quad 370,018$

Source: Miguel Urrutia, p. 132.

Without a doubt, forced sale of lands controlled by large landowners but cultivated by campesinos led to authentic land reform in certain regions of the country. Bergquist is correct when he asserts that such success achieved by collective action "in the early 1930's, as in parts of Cundinamarca and Valle (Informes 1934) was largely due to such organized movements, which obviously also affected the subsequent national legislation of the López government." 30

Although successes such as the victory achieved at the hacienda Sumapaz were numerous, particularly where the movements were given organizational impetus by UNIR or the Communist Party, many land occupations failed to attain legal title for peasants. Among these include the December 1931 occupation of 1,500 campesinos in Caldas who claimed titles to various portions of four haciendas, "La Argentina", "La Española", El Orinoco", and "Nápoles". After several "fact-finding" missions by local, departmental and national officials had been undertaken, all four property disputes were adjudicated in favor of the hacendados. ${ }^{31}$ In 1936, again in Caldas, 150 colonos were ejected from the properties that they had occupied for at least fifteen years when an unfavorable judgement was handed down by the Ministry of Industries. ${ }^{32}$

Indian resguardo lands also often fell victim to the new legislation. In one case, Indians were driven off their communal lands in south Tolima by the powerful landowners Marco Tulio Alvira, Leonardo Salamanca, and Gustavo Mosquera, with the complicity of local and regional officials. ${ }^{33}$ The lands were then successfully claimed by the landowners under the pretext of Law 200 by claiming that the land was commons. In Cauca, a group of Indians were also violently expelled from their lands in "El Chero" under the same

${ }^{30}$ Bergquist, Labor, p. 194.

${ }^{31}$ Gonzalo Sánchez, Ensayos, p. 180.

32Gonzalo Sánchez, Ensayos, p. 181.

${ }^{33}$ Gonzalo Sánchez, Ensayos, p. 203. 
pretext. ${ }^{34}$ Thus, while Law 200 was relatively effective in some regions in restoring lands to peasants and colonos, such as in Cundinamarca and Antioquia, it was ineffective in other regions which had strong traditions of powerful hacienda owners such as in Caldas, and achieved mixed results in regions such as Tolima and Valle del Cauca. Although the agrarian reform was successful at reducing agrarian conflicts, it also undermined many claims made by peasants and other smallholders to the plots of land that they had occupied and worked.

One factor that worked against communist and left-wing liberal organizers and provided stiff resistance to cooperative forms of organization was the strong individualist sentiment of the Colombian peasant. ${ }^{35}$ Labor shortages in the late 1920's and early 1930's gave workers in the Colombian coffee industry special leverage. The large hacendados had to pay top salaries to attract workers to bring in the coffee crops, and in many cases, the landowners had to make concessions in terms how their tenants used the land; many landowners were forced to allow tenants to grow coffee on the plots of land where the peasant and his family lived.

Also during this period, colonos and other workers who were engaged in growing coffee formed alliances with élites of the Liberal or Conservative parties, in many cases permitting the smallholder to make a successful bid to obtain individual title to a parcel of land through such clientelist ties. Although initially one route adapted by the smallholders was collective action against encroachments of powerful large landowners through organized resistance taking the form of the ligas campesinas, many employed the successful strategy of using their individual clientelist ties with the traditional parties to advance their claims. Such successful individualist strategies coupled with the strong desire to own their own land helped make many rural workers far more receptive to élite ideologies which also happened to extol the virtues of individual ownership of private property, than to leftist messages of communal ownership of property. Bergquist writes the following in defence of this view:

If the terms of struggle reinforced their individualism, their receptivity to the ideological message of the ruling class, and their conformity to the clientelist politics of the traditional parties, it left them resistant to collective organization and leftist ideology and carried them inexorably toward fratricidal conflict-it was not because smallholders were rendered less

${ }^{34}$ Gonzalo Sánchez, Ensayos, p. 203.

${ }^{35}$ This point has been discussed in Chapter Six of the present work. See Bergquist's argument on the Colombian peasant-as-entrepreneur in his Labor in Latin America, pp. 320-331. 
human by their experience and their struggle. It was because their intelligence and enormous energy were channeled by the structural imperatives of their existence into a destructive individualist dynamic beyond their control. It was the very success of coffee smallholders that sealed their fate as a class and ensured the decline of popular social and political forces in Colombia during the 1930's and 1940's. That process castrated an insurgent labor movement, led to the co-optation of the political left, and ended in the Violence at mid-century. ${ }^{36}$

Even though small-holders were relatively successful at obtaining title to land, as William McGreevey argues, the Federación Nacional de Cafeteros allowed the élite to maintain control over the coffee industry by controlling transport, marketing, and export functions. Their strategy, argues McGreevey, was to "...let production units fall back to their natural size, roughly that which could be managed and cultivated by a single arrendatario and his family along with a crew of seasonal workers. Restrict the access of those producers to the market by filtering their product and sales through a national organization controlled by the nation's senior economic leadership. Operate the system not for individual gain but for a class of senior executives identified by the industry as a whole." 37

While individual peasants struggled to obtain right to the lands they worked by employing the individualist strategy of utilizing their clientelist ties, their endeavors coincided with a dramatic change in the tactics of the Colombian Communist Party. The Liberals did not merely articulate and employ a carefully designed strategy to coopt the left, they were actually abetted in their plans by tactical manoeuvres of the left itself, moves which ultimately played into the hands of the Liberals. The Communist Party's decision in 1937 to adopt the strategies elaborated at the VII Congress of the Communist International, which basically promoted alliances with social democrats and other bourgeois groups with a reformist bent, was as one contemporary communist writer states, "disastrous for the revolutionary movement." 38

During the Third National Worker's Congress held in Cali in 1937, the Communist Party declared its desire to "facilitate its unification with the three currents which oriented and directed the popular movement, leaving it nearly entirely in the command of liberalism,

\footnotetext{
${ }^{36}$ Bergquist, Labor, p.330.

${ }^{37}$ William Paul McGreevey, "Reinterpreting Colombian Economic History," Journal of Interamerican Studies and World Affairs, Vol 23 No. 3 (August 1981). p. 359. Bergquist makes the same argument.

${ }^{38}$ Gonzalo Sánchez, Ensayos, p. 199.
} 
which at this time corresponds to the historic mission to conserve democracy." 39 While it is true that as early as 1928 the Social Revolutionary Party had welcomed the Liberals as allies who "embraced a revolutionary ideology and temperament" 40 in their effort to present a united front in order to defeat the reactionary Conservatives, by declaring its solidarity with the government of López, the Communist Party went much further, renouncing its leadership of the revolutionary movement, and declaring itself the champion of order and peace: "en reconocer desde ya la preeminencia debida al Partido Liberal, como partido democático de mayores masas dentro de las organizaciones del pais." 41 A year later, the rationale for the Communist Party's stance was succinctly stated in another article appearing in the party's official publication, Tierra: "...Pensamos que hay estadios (sic.) que llenar antes de nuestro turno, y que es el liberalismo quien debe ejecutar esa tarea..." 42

Strict adherence to the national party's interpretation of the International's line and the party's insistence on rigidly adhering to ideologized visions of the ideal society based on foreign, external models, obscured from the party's leadership actual Colombian social reality in the countryside. What Helio Jaguaribe wrote of the Communist Party in Argentina is equally true of the Colombian Communist Party:

Founded to be the party of the working class and the great masses, the party was not able to extend its appeal beyond the restricted circle of specialist workers...and still less to mobilize the great masses. Eventually it gained academic and political respectability and became representative of a certain sector of the middle class, mostly composed of intellectuals and bureaucrats, who at the theoretical level adopted the most radical view but in a purely abstract form-a view which was essentially unconnected with their socio-historical conditions and their concrete lives. ${ }^{43}$

While the Communist Party sowed the seeds of its own destruction, ${ }^{44}$ in terms of national influence in the affairs of labor, the issue had already been decided:

${ }^{39}$ Tierra, January 1937, quoted in Gonzalo Sánchez, Ensayos, p. 199.

${ }^{40}$ Gerardo Molina, Las Ideas Liberales en Colombia: 1915-1934, p. 230.

41Tierra, February 1937, No. 152, quoted in Gonzalo Sánchez, Ensayos, p. 199.

${ }^{42}$ Tierra, January 14, 1938 No. 150, in Sánchez, Ensayos, p. 200.

${ }^{43}$ Helio Jaguaribe, "Marxism and Latin American Development," in Marx and the Western World (1966), pp. 229-252.

${ }^{44}$ In the latter half of 1938 , members openly debated whether or not to abolish the party. See Gonzalo Sánchez, Ensayos, p. 201. 
overwhelmingly, Colombians remained loyal to the two traditional parties. Although rural workers seemed to have been roughly evenly divided in their support of the liberal and conservative parties, urban laborers displayed a strong preference for the Liberal Party. Hobsbawm correctly asserts that during this period, "a tendency to chose Liberalism as the party 'of the people' makes itself felt, encouraged by the development of socially conscious or "New Deal" forces within the Liberal Party. ${ }^{45}$

The following section will explore how those "New Deal" forces became a Liberal blueprint for social reform during la Revolución en Marcha.

\section{LA REVOLUCÍON EN MARCHA}

By the 1930's, as a result of rapid urban growth the balance of power in Colombia had tipped in favor of the Liberal Party, which had traditionally been stronger in the cities. Liberal governments in the 1930's and 1940's strongly encouraged the growth of labor organization, largely due to the influence of Los Nuevos. As Hobsbawm writes, "no doubt in 1928-48 the force which transformed Colombian politics came from popular movements. No doubt the institutional changes which followed found a more suitable vehicle in the Liberal Party, for partly ideological reasons - because this party believed in "progress," "economic growth" and "the people" rather than in "order," "tradition" and "hierarchy." No doubt the small groups of radical ideologues who provided the impetus of the change (in terms of politics and ideas) contributed to the institutional changes." 46 With the election of the first Liberal government in nearly fifty years, a trend leading to the Liberal corporativist incorporation of labor movement was set in motion. ${ }^{47}$

The Liberal governments of Enrique Olaya Herrera (1930-1934) and Alfonso López Pumarejo (1934-38, 1942-45) embarked on a path of social and economic reform. Several socialists held important post during their administrations, each contributing his own individual efforts to orient the party towards labor. Among the voices from the left were Lleras Restrepo, the former president of the socialist-oriented National Student Union, who became Minister of Finance in 1938 and Jorge Eliécer Gaitán who held ministries and

\footnotetext{
${ }^{45}$ Hobsbawm, "Ideology," p. 197.

46Hobsbawm, "Ideology," p. 189.

${ }^{47}$ See Manuel Moncayo and Fernando Rojas' Luchas obreras y política laboral en Colombia (Bogotá: 1978) for an incisive analysis of the affect this corporativist legistation had on coopting Colombian labor.
} 
mayoralties between 1936 and 1942 and occupied the office of Vice President of the Republic. ${ }^{48}$

At a time when the one overriding concern of Colombian politicians was to attract foreign capital, Enrique Olaya Herrera, a moderate, was chosen by the Liberals. Ambassador to the United States, Olaya was also selected because he was a compromise candidate that the Conservatives could live with. Highly erudite, from an old established family, the believed that Olaya would serve as an ideal candidate to lead a transitional government of "concentration" 49 .

In broad terms, the Liberal program sought to modernize the state by modernizing state administrative functions, rationalizing finances, and developing a group of highly trained technocrats to run government programs and offices efficiently. Olaya's government continued to follow the path of import substitution through protection of domestic industries and also protected agricultural production. During the first three years of Olaya's term, more than 840 industries were created under this program..$^{50}$ Other reforms undertaken during Olaya's presidency include the creation of limited public housing programs, regulation of the oil industry, and reforms leading to increased access by average Colombians to education and public health programs.

In labor politics, Law 83 of 1931 recognized the rights of workers to legally form unions. The law also provided for government regulation of the unions' right to strike. Other legislation passed during Olaya's term included Law 105 of 1931 that outlined circumstances in which salaries could not be garnished and Law 134 that recognized the legal status of cooperatives. ${ }^{51}$ The following year legislation covering retirement compensation was passed and Law 10 established specific guidelines for workers' rights to vacation, sick leave, and compensation for unjust dismissal ${ }^{52}$ Finally a presidential decree in 1934 legalized a right for which laborers had long struggled: an 8-hour work day. ${ }^{53}$

${ }^{48}$ Fals Borda, Subversion, p. 139.

${ }^{49}$ For the social and political thought of Olaya Herrera, see Gerardo Molina, Las Ideas Liberales en Colombia, 1915-1934 (Bogotá, Colombia: Ediciones Tercer Mundo, 1982).

50Molina, Las Ideas Liberales en Colombia, 1915-1934, p. 247.

${ }^{51}$ Molina, Las ideas liberales en Colombia: 1915-1934, p. 247.

52Molina, Las ideas liberales en Colombia: 1915-1934, p. 248.

53Daniel Pecaut, Politica y sindicalism en Colombia, p. 121. 
Despite such progressive reforms, a number of strikes were called during Olaya's presidency, including a strike of Antioqian railroad workers in 1932 that the government declared illegal on June Second. ${ }^{54}$ Most strikes between 1931 and 1934 however, were resolved in favor of workers.

One reason for the great increase in strike activity during Olaya's presidency, in addition to the legitimization of labor organization, was the economic crisis of 1929-31. During that period national income fell from 75 million pesos to 35 million, while at the same time foreign trade declined in value from 122 million pesos in 1929 to 80.4 million pesos in 1931 and 68 million in 1933.55 Imports fell during same period from 162 million pesos in 1928 to around 50 million pesos between 1931-33.56 On the other hand, industrial growth proceeded apace, 842 industrial establishments created during this same period, ${ }^{57}$ growth averaging 10.8 percent per year between 1933 and 1938.58

The strongest pro-labor government of the 1930's was the first presidency of Alfonso López (1934 - 1938). Although Law 83 of 1931 had had the effect of legalizing both labor unions and collective bargaining, 59 the López government passed additional legislation that increased the protection of laborers and provided them with important social welfare benefits.

López, son of a wealthy coffee exporter, early gained a reputation in politics in the 1920 's by attacking the Conservative government, especially the fiscal policies of Méndez "prosperity by debt" that López believed were leading to "the stratification of the nation." 60

${ }^{54}$ Ricardo Sanchez, Historia Politica de la Clase Obrera en Colombia (Bogotá: Editorial la Rosa Roja, 1982.), p. 89.

${ }^{55}$ Gerardo Molina, Las Ideas Liberales en Colombia. 1915-1934, p. 243.

56.Gerardo Molina, Las Ideas Liberales en Colombia, 1915-1934, p. 244.

${ }^{57}$ Gerardo Molina, Las Ideas Liberales en Colombia, de 1934 a la Iniciación del Frente Nacional (Bogotá, Colombia: Ediciones Tercer Mundo, 1986), p. 23.

${ }^{58}$ Moncayo and Rojas, Luchas, p. 58.

${ }^{59}$ Moises Troncoso and Ben Burnett, The Rise of the Latin American Labor Movement (New York: Bookman Associates United Printing Services, 1960), pp. 82-88; and Oquist, Violence, p. 160.

${ }^{60}$ Fluharty, Dance of the Millions, p. 47. For the political thought of López Pumarejo, see the concise article by Alvaro Tirado Mejía, "Algunos Aspectos del Pensamiento de López Pumarejo," Revista Universidad de Medellin, Medellin: Editorial Lealon, Vol. 49, (May, 1986). Also see Gerardo Molina, Las Ideas Liberales en Colombia, de 1934 a la Iniciación del Frente Nacional and Thomas C. Tirado, Alfonso López Pumarejo: El Conciliador (Bogotá: Planeta Editorial S.A., 1986). 
López had a work background ideally suited to the task of modernizing the government. He had served as an agent for Baker-Kellogg investment bankers, helping to direct the massive influx of American investments during the Dance of the Millions, worked as both a newspaper writer and editor, and had served a term as Colombia's ambassador to England in 1931.61

Despite López' upper class background, it was he rather than Gaitán who first shook the traditional élite-dominated political establishment. Socialist historian Gerardo Molina describes him in the following way: "Ese burgués libre de prejuicios, imaginativo y penetrante, tenía una personalididad fuera de serie que le permitía ir contra el orden corriente de las cosas....López se fue radicalizando hasta el punto de que durante su primer mandato se enfrentó a su clase y a ratos era el más expresivo vocero de los insumisos e inconformes." 62

López detested caudillismo, and was uncompromising in his defense of democracy as he understood the concept. An advocate of universal suffrage, for López, the middle class, urban workers, campesinos, and lastly, the upper classes comprised the pueblo, and each individual had a right to participate in society's political affairs. He believed that the majority, mostly workers, campesinos, and the growing middle class represented the true will of the pueblo, and given the assistance of a basic education, could well guide the development of the nation. López went so far as to criticize the "oligarchy" which had long ruled Colombia as being out of touch with social reality and national imperatives. In his acceptance speech as candidate for the Liberal party in November 1933, he proclaimed:

No encuentro en la historia nacional el ejemplo de un período de gobierno que nos se haya constitutuido como una oligarquía, más o menos disimimulada, o que no haya derivado hacia esa forma de mando, olvidando sus obligaciones con los electores. El poder público ha rotado así durante un siglo, azarosamente en los días de guerra civil y con indiferencia en la paz, de una oligarquía a otra, de un círculo a otro, de una casta determinada a su antagonista o a la heredera de sus simpatías..." 63

Among López' intellectual debts are included his Liberal forerunner, Uribe Uribe, the Peruvian Apristas and the Mexican Constitution of 1917, the first constitution in the continent to outline the legal responsibilities of the state in the economy, education, and the

${ }^{61}$ Fluharty, Dance of the Millions, pp. 47-48.

${ }^{62}$ Gerardo Molina, Las Ideas Liberales en Colombia, de 1934 a la Iniciación del Frente Nacional, pp. 11-12. ${ }^{63}$ Gerardo Molina, Las Ideas Liberales en Colombia, de 1934 a la Iniciación del Frente Nacional, p. 49. 
first to declare the social function of property. ${ }^{64}$ Other sources included the policies of his contemporary in the United States, Franklin Roosevelt's New Deal, as well as Socialist and Marxist thought.

López saw himself at the head of a movement to create a revolutionary new social and economic order through his, Revolución en Marcha, but not through violent revolution. He wanted to disperse more widely land-holdings because he believed both that the land would be more productive and that such a measure was democratic: it would help raise the standard of living of rural masses effectively enabling them to participate more fully in society. He was also keenly aware of the power differential between the oligarchy and workers. It was the state that had a moral obligation to protect the rights of workers.

It was the state that also assumed the obligation to undertake the primary responsibility for educating the nation's citizenry so that all Colombians could be informed participants in the political life of the nation. Under López, the Catholic Church's role as the nation's provider of education was dramatically reduced, the primary role being placed in the hands of the state. ${ }^{65}$ López also pushed education programs for workers, including programs to create a technically qualified group of professionals to run modern society. In an address to Congress in 1935, he stressed the need for new types of professionals: "Faltan químicos industriales, directores de taller, mecánicos, agrónomos y no tenemos institutos que estén tratando de prepararlos. Las facultades universitarias producen abogados, doctores en filosofía y ciencias socialies, médicos, ingenieros y dentistas. Y esto no es suficiente. Es urgente ponernos al día en el manejo elemental de una civilización importada, cuyos recursos ignoramos y cuyos instrumentos escapan a nuestro dominio. Mientras ello no ocurra no habrá autonomía nacional, no habrá independencia económica, no habrá soberanía."66 As a result of his belief in the power of education, between 1935 and 1938 the national budget allocated for education quadrupled, primary school was made free and compulsory, normal schools were established, and the Universidad Nacional,

${ }^{64}$ Robert Dix in his earlier book, Colombia: The Political Dimensions of Change (New Haven and London: Yale University Press), 1967, p. 82.

${ }^{65}$ The legislation removed church control of primary education, barred priests from holding public offices, and removed the clause in the Constitution declaring Catholicism the official state religion. See Fluharty, Dance of the Millions, p. 54.

${ }^{66}$ Quoted in Gerardo Molina, Las Ideas Liberales en Colombia, de 1934 a la Iniciación del Frente Nacional, p. 25. 
which boasted a more modern, practical curriculum than traditional universities, was founded. 67

In 1936 constitutional codification was undertaken, giving the state a legal role in economic development of the nation. The codification provided a legal means to protect domestic industry and agriculture, promote economic growth by establishing credit institutions and strengthening those already existing. Article 19 also provided the basis for the creation of social welfare programs, declaring that, "Public assistance is a function of the state. It shall be given to persons who, being physically incapable of working, lack the means of self-support or the right to demand the same of other persons. The law will determine in what form assistance shall be given, and the cases in which the State should give it directly." 68

Article 20 of the Codification was probably the most radical measures of all, declaring that property had a specific social function. ${ }^{69}$ Article 20 states:

Private property and other rights legally acquired in accordance with the civil laws by natural or juridic persons shall be guaranteed; nor may they be disavowed by later laws. When the enforcement of a law passed for reasons of public utility or social interest conflicts with the rights of individuals, private interests must give way to the public or social interests. Property is a social function which implies obligations. For reasons of public utility or of social interest, as defined by the legislature, property may be expropriated by judicial decree with prior indemnification. Nevertheless, the legislature, for reasons of equity, may deny indemnification by means of an absolute majority vote of the members of both Houses. ${ }^{70}$

Explaining the rationale for the new law, López offered the following: "El partido considera el territorio de la república como patrimonio de todos los colombianos; favorece cualquier iniciativa que tienda a lograr que la propiedad territorial cumpla satisfactoriamente la función social que le corresponde y reconoce al trabajo como fuente primordial de la propiedad privada."71 Fluharty argues that the inordinate length of time stipulated in Article 39 , ten years, castrated the provision, "in practice, almost no land returned to public

${ }^{67}$ Fluharty, Dance of the Millions, p. 54 .

${ }^{68}$ Fluharty, Dance of the Millions, pp. 53-54.

${ }^{69}$ Fluharty, Dance of the Million.s, p. 54.

${ }^{70}$ Quoted in Funk Harries, "Camilo Torres Restrepo", p. 259.

${ }^{71}$ Gerardo Molina, Las Ideas Liberales en Colombia, de 1934 a la Iniciación del Frente Nacional, p. 18. 
hands under this provision."72 Nevertheless, the new legislation drew unconditional condemnation from Conservatives and right-leaning Liberals alike. More likely than not, it was the direct catalyst leading to the creation of the Asociación Patriótica Económica Nacional (APEN) in 1936, a coalition of latifundia owners, entrepreneurs, and industrialists formed to resist the new pro-labor, pro-smallholder legislation. ${ }^{73}$

Another important and controversial law passed the same year was Law 200 of 1936. The first major agrarian reform in Colombia, it was designed to clear up conflicts over land titles. As discussed earlier, Law 200 actually set back many small independent landholders since it sanctioned many of the large landholders' property claims. ${ }^{74}$ While legitimating land claims for thousands of small-holders and colonos, it also led to the legal eviction of thousands of peasants. Regardless of its outcome, the intent of Law 200 was clear: to provide idle land for campesinos to put into productive use. Soon after López had been elected, he was besieged by letters form large landowners in Cundinamarca and Tolima demanding that the government take action against squatters who had invaded uncultivated lands. His response was unsettling to the landowners: the law cannot be put to the unconditional service of injustice, and although the country's legal institutions were made to defend the owner of property and to maintain the level of misery of the rural wage earners, the government, without ignoring its duty to protect the landowners whose land was cultivated against squatters, prefer[s] to wait until the constitutional reforms it [has] proposed [gives] it better instruments for intervention in the social problems of agriculture. ${ }^{75}$

He added that the government's main intention was to improve the campesinos' standard of living and "to condition the right of property to its rational economic use."76

Among the most unpopular laws in the eyes of the élite passed during López tenure were the provisions that led to the creation of a progressive income tax (Law 78). As Fluharty notes, taxes in Colombia were ineffectually collected: "No one paid taxes, except in the manner of a government making a symbolic payment on its external debt." Under

${ }^{72}$ Fluharty, Dance of the Millions, p. 54.

${ }^{73}$ Fals Borda, Subversión, p. 139

${ }^{74}$ LeGrand, "Labor Acquisition", (p.45) Oquist Violence, (p.98) and Gloria Gaitán, La lucha por la tierra en la década del 30, (Bogotá, 1984), pp. 90-92, all hold this view.

75Miguel Urrutia, Development, p. 123.

${ }^{76}$ Miguel Urrutia, Development, p. 123. 
the new law, the following provisions were enacted: the maximum tax on net income was 17 percent; a patrimony tax was put into place on profits in excess of 12 percent per year and these could run as high as 30 percent. 77 Most unnerving for the wealthy however was the government's determination to collect these taxes: in 1939, new revenue amounted to more than nineteen million pesos and the number of tax-paying business concerns increased by 256 percent over pre-López days. ${ }^{78}$ This move led to a major expansion of government revenues as well as a shift away from customs receipts in favor of income tax as the major revenue earner.

Again, this legislation alienated the nation's industrialists prompting APEN to launch a campaign to fight the tax reform. ${ }^{79}$ Its members claimed that this move, along with the social function of property clause mentioned previously and other reforms, was a communist inspiration.

While such government initiatives as the national income tax made him many enemies among the élite, ${ }^{80}$ López received broad-based support for his programs from workers and rural laborers. As a result of the unease felt by both moderate and right-wing Liberals at the pace of the reform program however, moderate liberals led by Eduardo Santos in Congress argued that it was time to slow the Revolución en Marcha in an effort, they claimed, to consolidate the party's gains. In 1938, Santos was selected over the Lópista candidate by a slim margin at the Liberal Party Congress, and was subsequently elected president of the Republic. In 1942 however, López was again elected to the presidency.

\section{CREATION OF THE CONFEDERACIÓN DE TRABAJADORES DE COLOMBIA (CTC)}

As discussed above, Law 83 passed during the Olaya Herrera presidency legalized the rights of unions to organize. As a consequence, the Confederacion Sindical de Colombia, later renamed the Confederación de Trabajadores de Colombia (CTC) was organized in 1936. By 1943, the Confederacion would be comprised of 900 locals and

${ }^{77}$ Gerardo Molina, Las Ideas Liberales en Colombia, de 1934 a la Iniciación del Frente Nacional, p. 53.

${ }^{78}$ Fluharty, Dance of the Millions, p. 55.

${ }^{79}$ Gerardo Molina, Las Ideas Liberales en Colombia, de 1934 a la Iniciación del Frente Nacional, p. 53.

80 Laureano Gómez, leader of the Conservative party apparently justified plots to assassinate López. See Urrutia, Development, p. 124. 
nearly 100,000 workers. ${ }^{81}$ The López government along with the Liberal Congress passed a series of laws to improve the conditions for workers. Article 18 of the codification gave unions, except those comprised of workers in the public services, the right to strike; the law was subsequently implemented by Presidential Decree No. 2350, Law Number 6.82

Shortly after the CTC was organized, it began to receive financial support from the government. Not only did the Liberals support the Confederation by generally favoring labor over business in labor disputes in which government arbitrators intervened, the Second Labor Conference of the CTC was actually financed by a subsidy from the Liberal government. Minister of Government Carlos Lozano emphasized the importance the López administration placed on labor:

The government considers unions as organisms especially designed to improve the situation and discipline of workers and peasants, who by organizing will acquire a greater understanding of their duties and their rights.

Unions help to develop culture and professional education and contribute in many ways to the intellectual and social progress of the workers. [This] government wishes to sustain, encourage, and protect unions, watching that they limit their activities to those ends for which they have been created, without becoming immersed in political activities which weaken their authority and injure the worker's interests. 83

As one might infer from this statement, such government "protection," also implied increased government control. In 1937, the government passed a series of laws regulating union expenditures of government subsidies. ${ }^{84}$ The following year, Decree 2342 was promulgated creating a division of union supervision in the Labor Ministry, that was charged with the responsibility of regulating union elections, inspecting financial records, and endowed with other regulatory powers over the unions. ${ }^{85}$

The government also issued many veiled warnings such as the one above advising labor to avoid political activity. Under Santos' government in fact, the government would

${ }^{81}$ The figure of 100,000 is from Urrutia, Development, p. 183 and the 900 figure is taken from Fluharty, Dance of the Millions, p. 49.

${ }^{82}$ Fluharty, Dance of the Millions, p. 49.

${ }^{83}$ Oquist, Violence, p. 160.

${ }^{84}$ Oquist, Violence, p. 159.

${ }^{85}$ Miguel Urrutia, Development, p. 179. 
take an even more active role in limiting the influence of the communists in labor unions. Oquist describes what was happening to the labor movement during the Revolución en Marcha: "Progressively the labor movement became an instrument of the Lopista Wing of the Liberal Party which maintained a popular from alliance with the Communists in the Labor movement. Thus, the once belligerent labor movement was institutionalized and controlled by the Liberal governments of the 1930's. 86

Although the Liberal Party extended its support to labor groups, it did so in selective fashion. It held out as carrot its support for moderate unions and labor organization while applying the threat of martial law as a stick for those it considered too radical. For example, the government supported the laborers of Tropical Oil in Barracabarmeja during a labor dispute in 1934. It also pressured the management of United Fruit to make wage concessions during the 1935 strike in the Department of Magdalena. However, in response to a violent rail strike in Antioquia, the government declared martial law. ${ }^{87}$

It is important to note that all major strikes during the late 1930's were settled only after the government had intervened. Between 1935 and 1939 of 218 labor-management conflicts, 155 were resolved after official intervention, 70 after the workers had resorted to a strike and 38 were resolved by direct negotiations between the parties. ${ }^{88}$ Most conflicts, as mentioned above, were resolved in favor of labor.

During the Presidency of Eduardo Santos (1938-1942), the Liberal Party's relationship with labor became strained. Most labor leaders had supported Santos' opponent in the campaign, López' Minister of Education, Darío Echandía. Santos, though not especially antagonistic towards labor, was especially interested in keeping the socialist and communist influence in the CTC at bay. He stated:

Yo he visto con inquietud varias veces expresando públicamente, el hecho de que la confederación sindical de Colombia aparezca presidida y dirigida por elementos que son en su mayoría enemigos del liberalismo. Yo no considero que sea indiferento para los intereses del liberalismo, ni que sea inocente para los fines que debe perseguir la organización sindical el que a la

${ }^{86}$ Oquist, Violence, p. 161.

${ }^{87}$ Oquist, Violence, p. 161.

${ }^{88}$ Ricardo Sanchez, Historia politica de la clase obrera en Colombia, p. 91. 
cabeza de ella figuren todos, absolutamente todos, los jefes del socialismo y del comunismo en Colombia ${ }^{89}$

Born to a wealthy family and editor of the prestigious Liberal newspaper $E l$ Tiempo, under Santos the government sought to slow the growth of labor organizations. During his presidency, labor was less combative and there was a dramatic reduction in the total number of active unions. As a result of over-reliance on state protection, the number of unions (one probably exaggerated estimate places the number of active unions at 16 reduced from a pre-Santos total of 167) as well as a drastic decline in strikes. ${ }^{90}$. The new Liberal government also sought to control unions through government control of funds, by requiring government officials' attendance in union meetings, by prohibiting strikes in the public service sector, and by designating the plant union as the principal bargaining unit for collective negotiations (preventing the collective pressure that could be brought under industry-wide unions). ${ }^{91}$

The 1941 Liberal convention was a frenetic one, pitting the moderate forces of Santos against the left-wing of the party dominated by the Lopistas. The moderate Liberals and the Conservatives supported Arango Vélez, a well-known Bogotá attorney. López won the election by a mere 200,000 votes, Conservatives charging that the elections had been rigged.

Under the second government of Alfonso López, the tempo of social reforms slowed dramatically. Socialist writers mark the period of 1942 through 1946 as the era in which the industrial bourgeoisie placed the labor movement under the definitive control of the state. ${ }^{92}$ It does appear theat the pace of the institutionalization of labor quickened while the government's former focus on social change was greatly diminished. In 1943, for

${ }^{89}$ Cited in Moncayo and Rojas, Luchas, p. 61, n. 29.

90Daniel Pecaut, Política y Sindicalismo en Colombia (Bogotá: Ediciones Culturales, 1982), pp. 194195.

${ }^{91}$ Pecaut, Política, p. 197.

${ }^{92}$ Cesar Mendoza Ramos, Surgimiento y Desarrollo de la Clase Obrera en Barranquilla, Paper presented at the Third Congress of Colombian History, Universidad de Antioquia, Medellín, Colombia, (November, 1981), p. 11. In reality, the Liberals sought to control labor from the beginning of the first Liberal government in 1930. Law 83, for example, prohibited unions from engaging in politics upon the threat of dissolution by the government. 
example, the Congress passed legislation limiting unions' rights to strike and established a requirement for obligatory arbitration after 30 days of strike. ${ }^{93}$

While the second López administration was more restrictive, the period also witnessed a major expansion of unions. Of the 1,645 unions that existed in 1947, nearly half, some 719, were new unions established.during López's second presidency. ${ }^{94}$ After an abortive military coup, López determined to push through legislation that would systematize labor-management relations. Justifying his actions, in 1944 López wrote:

Las leyes existentes son insuficientes, son contradictorias, son ineficaces para prevenir tales conflictos y no los encauzan hacia desenlaces de justicia sino con lentititud exasperante. La huelga, la fuerza sindical, la coacción, imponen después de un tremendo forcejeo que altera la paz social, ventajas que muchas veces han sido reconocidas a las clases asalariadas por las propias leyes. El Gobierno carece de medios suficientes para hacer aceptar sus dictámenes y por tanto sus intervenciones son generalmente estériles. ${ }^{95}$

In an effort to consolidate the labor laws that had been passed during the 1930's and 1940's, in 1945 presidential efforts led to the promulgation of Law 6, which became known as the Colombian Labor Code. Law 6 established a minimum wage, regulations for severance pay, pay for Sundays not worked, regulations on workplace safety, compensation for work-related accidents, and nonoccupational illnesses, two-week paid vacation, overtime pay and job security guarantees for union leaders. ${ }^{96}$ It also prohibited management from contracting scab labor during legal strikes. Legal is the operative word, referring to strikes that were not in the public services, that had objectives which were not legally proscribed, that followed the legally prescribed conciliation procedures, that the strike was peaceful, and that the strike be declared by a majority of members in the union, as long as the unions was comprised of more than 50 percent of the enterprise's workers. ${ }^{97}$ Despite the more moderate pace and tone of López' second government however, opposition to his programs continued to mount.

${ }^{93}$ Pecaut, Polífica, p. 203.

94Pecaut, Política, p. 196.

${ }^{95}$ El Tiempo, October 10, 1944, cited in Moncayo and Rojas, Ensayos, p. 66.

96Urrutia, Development, p. 163.

${ }^{97}$ Urrutia, Development, p. 163-164. 


\section{CONSERVATIVE REACTION}

Strong Conservative opposition to the extensive reforms of the Liberal government began making itself felt as early as 1935, and thereafter accelerated. After 1937, opposition from the right wing of the Liberal Party also began to appear, but the moderate presidency of Eduardo Santos temporarily suspended it from becoming a major threat. Conservative chieftain Laureano Gómez' criticism of the Liberal government was even more vocal during López' second term, playing on the interests of both landowners and entrepreneurs who felt threatened by a Liberal government dedicated to ensuring that labor received a larger share of the benefits of industrial development. López's agrarian policy had made many enemies among the powerful large landowners, and his secularizing reforms had alienated the hierarchy of the still-powerful Catholic Church.

In an effort to counteract the growing influence of labor groups, businesses and large landowners stepped up the activities of APEN. Other organizations such as the Asociación Nacional de Industriales (ANDI) and the Federación Nacional de Comerciantes (FENALCO) were also created to preserve and further the interests of business and to attempt to halt the Liberal reforms.

Acción Catolica led by Father Vicente Andrade established a new labor central, the Union de Trabajadores de Colombia (UTC), the Workers Union of Colombia in 1946. Although the new confederation declared that it would not become embroiled in political partisanship, the Conservative government smiled broadly upon the UTC while decisively repressing the CTC. By early 1949 , the new union would have as many members as the CTC. Moreover, while the UTC did not declare its partisanship openly, the influence of a resurgent, conservative Catholicism is apparent. In Article Three, the founding fathers wrote, "The Confederation shall adopt as the fundamental basis for its struggle, the principles of Catholic Social Doctrine, as taught by the Popes. The Confederation shall inspire and orient its campaigns according to these doctrines, and within the law." 98 The momentum that a semi-autonomous labor movement had gained under successive Liberal governments abruptly ended in 1945.

In his second term, President López was not only faced with criticism from the Conservatives, but also began to be faced with growing dissent among moderate and right wing elements in his own party. As a result of mounting pressure applied by these groups that were disenchanted by the broad scope and rapid pace of his social reforms, and racked

${ }^{98}$ Urrutia, Development, p. 212. 
by a scandal in his family that seriously damaged his credibility, President López resigned in 1945.

In his resignation speech, López talked about the chasm between politicians and workers, focusing on the right wing's flirtation with European fascism and hinting at the development of a working class consciousness that could become revolutionary and threaten Colombian democracy. ${ }^{99}$ He wrote:

It alarms me that there should be created-as it appears there has been created-a political class far removed from the vital interests of the Colombian worker, from his present preoccupations and his legitimate ambitions...there are new factors of disorder which did not exist before. Such as the active industrial development which is causing and creating interests of such magnitude that they openly defy the force of the laws, the power of the Executive Branch and of Justice itself. Such as the awakening of a sleeping social consciousness which can turn toward violence more easily when it learns that violence produces concrete results. Such as, finally, the disorganization of the contemporary world, in which it was our lot to see abolished by force, and still not yet reestablished, the essential principles of our political and social civilization, and the victory, though fleeting, of other forms, all arbitrary and subversive of our classical tradition. 100

In López's place stepped Alberto Lleras Camargo, who adopted a markedly different stance towards organized labor. During his administration, government intervention on behalf of the workers during labor disputes was all but ended.

A pronounced shift in the mood of the Liberal Party is reflected in a Liberal writer's comment in late 1945 in Revista de la Universidad de Antioquia that although many unions had been forced to organize outside the law before 1931, the Liberal Party had championed their cause after that date by enacting pro-labor legislation. The author cautioned, however, that "la intervención política de los sindicatos, infortunadamente para los trabajadores, para el Estado, para la Nación Colombiana y para el Liberalismo, ha venido siendo dirigida por

${ }^{99}$ Bergquist argues that this division was what the reformers were frightened of: "[what] moderate reformers within the Liberal and Conservative parties feared most was the polarization of Colombian politics into a reactionary repressive bloc, led by the right wing of the Conservative party, and a revolutionary socialist movement, formed out of an alliance between a Marxist labor movement and the left wing of the Liberal party." Bergquist, Labor, p. 241.

${ }^{100}$ Mensaje de Renuncia del Presidente López, cited in Fluharty, Dance of the Millions, pp. 76-77. 
los comunistas. Y el gobierno liberal, amigo de los trabajadores, en bien de ellos, no puede permitir que siga el estado actual de las cosas." 101

Along with the goal of providing oversight of the unions, the same author comments that the Departamento Nacional del Trabajo was created to obtain an "exact understanding of the activities" of the unions, and to carry out "investigations necessary to determine the conduct of unions suspected of violating statutes and according to the case...advising the appropriate Circuit Judge who may decree the dissolution of the union, in accordance with Law 83 of 1931." 102

Another dramatic example of the change in official government policy was Camargo's reaction to a strike of Magdalena river transport workers in November, 1945. Threatened by post-war inflation and increased levels of silting which had decreased river transportation, FEDENAL, the most powerful union in Colombia at the time, had organized a strike. ${ }^{103}$ After shipping companies had labeled the strike "revolutionary," in a radio address delivered to the nation, Camargo declared: "In this country there is only one government, mine. If the workers do not return to their labors today, they will receive exemplary sanctions. It cannot be permitted that there are two governments, one on the river and another in the rest of the country." 104

\section{THE DECLINE OF LABOR'S POLITICAL INFLUENCE}

In a show of support for FEDENAL strike, the Confederación de Trabajadores de Colombia called for a nation-wide sympathy strike. The government sided with the shipping company and sent troops to the area to keep the strikers from interfering with the company's operations. Although the work stoppage lasted until January 19, the strike ended in failure. "The labor movement lost momentum and autonomy," Borda writes, "and was unable to became firmly established among the people. For this reason it was relatively easy for President Lleras Camargo to subdue a labor strike on the Magdalena

${ }^{101}$ Adolfo Gómez Támara, "Lá intervención de los sindicatos en la política," Revista Universidad de Antioquia, (December, 1945), p. 520.

102 Adolfo Gómez Támara, "La intervención de los sindicatos", p. 521.

${ }^{103}$ Oquist, Violence, p. 112.

${ }^{104}$ Oquist, Violence, p. 112. 
river; it meant the end of the Confederation of Colombian Workers as an effectively organized labor force." 105

The labor movement suffered another setback in 1946, though it was not related to an abortive strike. The Liberal Party faced the 1946 presidential elections with two candidates; Gabriel Turbay, a moderate Liberal supported by the Communists and officially by the CTC, and Jorge Eliécer Gaitán, who garnered the support of urban labor. Gaitán conducted a populist campaign in the name of the país nacional, or the pueblo against the oligarchy, the país politico.

The right on the other hand was well prepared to enter the presidential race. At the time, the most influential leader in the Conservative Party was Laureano Gómez, the same caudillo who had endorsed Acción Intrepida, an earlier effort to assassinate López. Fluharty writes the following on Gómez:

Laureano Gómez, in many ways the real leader of the Conservative Party in these years, was particularly vehement in his denunciations of Liberalsindeed, of all who disagreed with his self-proclaimed mission to save Colombian society form "heresy" and "communism," and to preserve traditional Catholic values. Gaitán had conducted his 1946 campaign not so much against a party as against the 'oligarchy' that, in his view, ruled both traditional parties. ${ }^{106}$

Gómez, who edited the Conservative newspaper El Siglo, was educated as a civil engineer, was deeply Catholic and had a strong belief in law and order. Gómez adhered to a form of social Darwinism, believing that Colombia's indigenous peoples, blacks and even the mestizos who comprised the majority of the population were inferior. He claimed that mestizos were, "lisiológica y psicológicamente inferiores a las razas componentes."107

As was common in the right wing of the Conservative Party, Gómez admired Franco's Spain. El Siglo, the main Conservative newspaper was arguably pro-Axis. In a speech made at a 1937 banquet attended by diplomats from the Franco government visiting Bogotá, Gómez praised the Falange:

Spain, marching forward as the sole defender of Christian civilization, leads the western nations in the reconstruction of Hispanidad, and we inscribe our names in the roster of its phalanxes with unutterable satisfaction... we bless

105Fals Borda, Subversión, p. 141.

${ }^{106}$ Fluharty, Dance of the Millions, p. 35.

${ }^{107}$ From Laureano Gómez, Interrogantes sobre el Progeso en Colombia, (Bogotá, Populibro, 1970), pp. 44, 46-47. Quoted in Kalmanovitz, Economía, p. 269. 
God who has permitted us to live in an era of unutterable transformations, and who has given it to us to utter, with a cry that springs from the very depths of our hearts: "Up Catholic, Imperial Spain!"108

Gómez' partisans went so far as to organize the Camisas Negras, the Colombian equivalent of the Falange, at the Conservative leader's office at El Siglo. ${ }^{109}$

The rupture within the Liberal Party allowed a compromise Conservative candidate, Mariano Ospina Pérez, to be elected with only 41 percent of the vote. 110 President Pérez, the candidate of "National Unity," had little interest in cultivating labor's support. He stepped up the anti-labor policies begun by his Liberal predecessor. In 1946, for example, he sent troops to the Cauca Valley to quell a labor dispute that had arisen in Cali. Violent confrontations between strikers and the army led the government to declare a state of siege in the region. ${ }^{111}$ Again, in the face of government repression, the strike failed.

The reason for Ospina Pérez' antagonism towards labor should be viewed in terms of how he interpreted the nation's problems:

"Colombia [needs] an orderly revolution within the framework of peace. That is what we propose to bring about, from our position of power, in order to effect an authentic national transformation which will make Colombia a responsible and strong State... a small urban nuclei who have been led astray by demagogic propaganda, who do not see the worker's real interest, but only a chance to make political capital....The Country is tired of anarchy... it is not a question of repressing liberties, but of making liberty responsible. Every day I become convinced that we must make our national motto a reality: Liberty and Order. It is necessary to harmonize, not to oppose, these two factors of social energy." 112

In 1948, new decrees mandated government approval of union meetings and agendas, removed from the courts the right to declare public sector strikes illegal placing them instead in the hands of the executive branch, and weakened laws providing protection

${ }^{108}$ Fluharty, Dance of the Millions, p. 63.

${ }^{109}$ Fluharty, Dance of the Millions, p. 63.

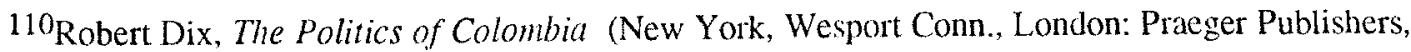
1987), p. 47.

111 Fals Borda, Subversión, p. 142.

112Fluharty, Dance of the Millions, p. 110 
from arbitrary firing of union organizers. ${ }^{113}$ A new labor code was also begun in 1948 that would continue to reverse much of the pro-labor legislation enacted during the Revolución en Marcha.

Throughout Pérez' presidency, Gómez served as the "power behind the throne," advising the President and virtually dictating the Conservative Party line. In 1949 Gómez decided that at long last it was his time to assume the presidency.

In 1950 ultra-Conservative Laureano Gómez (1950-1953) was elected to the presidency. During his term, which eventually earned even the disapprobation of his own party, new laws enforced provisions calling for government approval in order to hold union meetings, required the attendance of police officers or soldiers at labor functions, and led to the dismissal of many labor leaders from their jobs. ${ }^{114}$

After this event, labor organizers realized that their best chances of obtaining real bread and butter benefits for the workers, rested with the Liberal Party. The only other real alternative, was to accept a subordinate role to capital, along the lines of the UTC model, by utilizing collective bargaining strategies under Conservative governments hostile to militant labor activism. Oquist comments on this development: "The fate of the most important labor organizations thus became inextricably linked to the partisan struggle of the Liberal Party to block the formation of Conservative political hegemony."115 In actuality, as we have argued throughout this paper, labor had always been embroiled in the partisan struggle between the two great parties, taking brief spells of respite during occasions when its leaders felt that partisanship held no hopes of supporting the aims worker demands.

\section{GAITÁN AND THE LABOR MOVEMENT}

Gaitán has been criticized by many observers as an unscrupulous demagogue who manipulated the masses for his own political ends. Conservative President Mariano Ospina Pérez' brother-in-law Julio Hernández wrote, "[Gaitán] was an able jurist, but a demagogue with a vague policy which he defined in his party slogan 'Charge,' without making it clear against what, in what direction, or with what purpose...our demagogues,

\footnotetext{
113 Bergquist, Labor, p. 357.

${ }^{114}$ Urrutia, Development, p. 223.

115 Oquist, Violence, p. 114.
} 
whose principal was Gaitán, [took] advantage of the intellectual weakness and economic conditions of the poor people." 116

Yet reading his Las Ideas Socialistas en Colombia, one realizes that Gaitán's philosophy was relatively consistent throughout his political career. ${ }^{117}$ A demagogue perhaps, but he was not the opportunistic demagogue painted by Hernández. Gaitán constantly strived to achieve his ideal, to establish "el necesario equilibrio entre la gran mayoría que nada tiene, contra una minoría que posee todos los medios de producción y que explota al infeliz."118

Gaitán grew up in a marginal neighborhood, the son of a used bookshop keeper. Imbued with a deep respect for artisans and small business owners whom he had seen work hard to "salir adelante, Gaitán fought against corruption in government, other privileges accorded the élite in society as a benefit of their status, and a system in which patronage jobs were doled out help to non-professionals. A captivating speaker, he disapproved of both communism and fascism believing both to be undemocratic. In his eyes, a struggle existed in society between the Pueblo or the pais nacional (everyone except the élite) and the oligarquia or the país politico. Those who produced in society, the workers who created wealth, received unjust rewards from their labors. Gaitán's support base was the urban artisan and industrial worker.

Alberto Niño, Conservative and chief of national security under the Ospina Pérez government was a friend of Gaitán's. He described him thus:

Gaitán was a living paradox. He was a revolutionary who hated disorder; he loved the people...he attributed all virtues to them and execrated himself when, in his dealings with them, he discovered some of their defects. He liked politics, but lacked the tortuous and hypocritical discretion of the politician...he believed in truth, his truth was the Good, and for it he was dogmatic...incomparable leader of the masses, and an enemy of class conflict, still he roused in the country that very conflict by molding his actions and his words as an instrument for creating the consciousness of class among the popular masses. ${ }^{119}$

116 Quoted in Fluharty, Dance of the Millions, p. 78.

${ }^{117}$ Jorge Eliécer Gaitán, Las Ideas Socialistas en Colombia Tesis de Grado, 1924, (Bogotá: Librería Publicitaria, 1976).

${ }^{118}$ Quoted in Molina, Las Ideas Liberales en Colombia, de 1934 a la Iniciación del Frente Nacional, p. 252.

${ }^{119}$ Fluharty, Dance of the Millions, p. 80 
By 1947, the schism in the Labor Party had healed and Gaitán was recognized as the undisputed leader of the National Liberal Directorate. The Communists, who had abandoned Gaitán in the 1946 presidential elections and had supported the moderate Turbay, sought to return to the fold. Gaitán rejected their offer however, realizing that he no longer needed their support since Communist influence in Colombian labor and politics had long since waned. In March of 1948, Gaitán ended Liberal participation in the 'National Unity' cabinet of Ospina Pérez.

During the second world war, markets for Colombian exports such as coffee and bananas were constricted severely leading to a downturn in the economy and general decline in workers' standards of living. A 1947 issue of Foreign Commerce Weekly reported the following:

The cost of living index for Bogotá was 171.7 at the end of 1944, in comparison with 142.4 at the end of the previous year. In other cities the range was about the same. Industrial wages rose at a slower rate than the cost of living, and real wages had declined steadily since 1941 .

In November, 1946, the cost of living index of a workingman's family reached 229 (1937 as 100). It has continue to rise to record figures during each month since June, 1945 . Food rose to 233.6 , rent to 214.9 , clothing to 223.5. The index for the Bog food market showed an increase, advancing from 384.6 in October, 1946, to 405.9 in November. As a result of public pressures against rising prices and the high cost of living, the Colombian government reinstituted price control in 1946. The measure was not very successful, and at year's end, inflation appeared to be unchecked. ${ }^{120}$

Adding to the misery caused by the economic crisis was the continuing problem of cityward migration from the countryside which swelled the ranks of the unemployed. Warning of increased social strife caused by the economic dislocations, Gaitán requested that the government establish a Casa del Refugiado in order to ease the problems of homelessness. The government refused, stating, "Should we create, in our very homeland, an institution which formalized the fact, at arms' length, of persecution and martyrdom? Political violence is now only an exception to the rule, a misfortune which will gradually disappear." 121 The latter half of the Conservative government's response turned out to be a wishful prediction.

${ }^{120}$ From Foreign Commerce Weekly (Washington: US. Department of Commerce. Mar. 1, 1947), p.5, Quoted in Fluharty, Dance of the Millions, p. 92.

${ }^{121}$ Fluharty, Dance of the Millions, p. 88. 
Gaitán's leadership of the Liberal Party was short lived. In 1948, during the meeting of the Inter-American Conference in Bogotá, Gaitán was assassinated. The next day, rioters destroyed large areas of downtown Bogotá in what has become known as the Bogotázo. The Ninth of April, as the event is known in Colombia, erupted as the first episode of the most violent period ever experienced in the history of Colombia - La Violencia. ${ }^{122}$ Partisan political violence pitting Liberals against Conservatives would became the social norm in Colombia for the next twenty years.

\section{CONCLUSION}

Gradual, but profound changes in liberal ideology in the first three decades of the twentieth century helped to orient the political party to become much more responsive to the economic and social plight of the nation's workers. The Liberal Party was infused by the ideas and idealism of many young intellectuals such as Turbay and Gaitán among others, los nuevos, who had been active in the socialist movement of the 1920's. Other Liberal professionals not directly descending from a socialist tradition, such as those who had adopted Uribe Uribe's notion of state interventionism in the economy (Alfonso López) or those who were impressed by Keynesian economics (López and Herrera), also made their imprint.

It was the incorporation of socialist intellectuals, who had a great deal of influence among early labor organizations, into the Liberal fold that paved the way for the Liberal cooptation of an independent labor movement. At the same time however, it also made possible Alfonso López' Revolución en Marcha, the series of dramatic social and economic reforms undertaken by the Liberal governments of the 1930's and 1940's that helped to enhance workers' rights and working conditions considerably.

Significantly, during the time of López' first term, no other country in the nonCommunist world had a more comprehensive package of progressive labor legislation than Colombia. Liberal governments gave unions the right to legally organize, to strike for better benefits, and provided legislation to improve safety conditions, to establish the earlier socialist dream of a forty-hour work week, eight-hour work day and many other laws that generally improved living and working conditions for laborers. Other social reforms included creating and implementing a graduated income tax, nationalizing primary

${ }^{122}$ See Paul Oquist, Violence, Conflict and Politics in Colombia (New York, Toronto, San Francisco: Academic Press, 1980). Another interpretation by the radical priest-turned guerrilla in 1965 is Camilo Torres Restrepo, "La violencia y los cambios socioculturales en las areas rurales colombianas," Paper presented at the First National Sociology Conference, Bogotá, March 8-10, 1963. Torres was killed in an engagement with Colombian army regulars in 1965. 
education (which was also made compulsory) and increasing outlays on education fourfold, eliminating literacy and property restrictions on the vote, constructing new roads to link the country's regions more effectively, and establishing new credit institutions. ${ }^{123}$ The Liberals also sought change in an area traditionally considered as a primary Liberal mission: reducing the role the Catholic Church played in society. This was accomplished by resting control over public education from the Church and by striking the phrase in the Constitution of 1880 that recognized Catholicism as Colombia's official religion.

The government also passed a major agrarian reform law and took the unprecedented step of declaring that property had a social function: if it were not put into productive use as defined by the legislation, the property was subject to expropriation by the state. Law 200, part of the agrarian reform package, sought to clarify land titles and to make unused land productive. Despite the actual outcome of the legislation which has been described in some detail above, in its primary sponsor's eyes, Law 200 was an attempt to diffuse more widely land ownership in order to allow a greater share of the wealth to go to smallholders as well as an effort to make the land more productive. In short, it would ideally undergird the nation's democratic system by making relations in the countryside themselves more democratic.

Under reformist Liberal governments, organized labor flourished. The powerful Confederación de Trabajadores de Colombia was created during these years and tens of thousands of workers were unionized. While the number of unions multiplied, workers won important bread and butter gains, often through government intercession in labor disputes with capital.

Following the pause during Santos' term in the peaceful 'social revolution', López was again elected to the presidency in 1942. Although some important reforms were pushed through Congress during López' second term, opposition to continuing the reform program led to a more modest pace. The change in the political climate forced López to face a more formidable opposition from within the Liberal ranks themselves.

In 1945, after an abortive military coup, charges of rampant corruption in his administration and a personal scandal involving his family, López resigned. Right-wing Liberal Alberto Lleras Camargo took office determined to complete the year remaining in López term as the president of "National Union," attempting to affect a rapprochement with the Conservatives. A year later, Conservative Mariano Ospina Pérez would be elected to the presidency after the Liberal Party had split into two camps, one favoring continued

${ }^{123}$ Robert Dix, The Politics of Colombia, p. 34. 
reform and a close relationship to organized labor, the other focusing broadly on improving the nation's economy and maintaining an ambivalent, though not necessarily antagonistic attitude towards labor.

The Conservatives were much less friendly towards organized labor. Conservative governments discouraged independent union activities, restricted the use of strikes and promulgated a new labor code that sought to reverse much of the pro-labor gains achieved under the Revolución en Marcha. One labor federation that was supported by the Conservatives was the Unión de Trabajadores de Colombia (UTC). Vicente Caycedo, first president, later secretary general and ultimately historian of an important UTC affiliate in Barranquilla, remarked that the labor federation's strategy was to focus on economic negotiations, avoid strikes if at all possible, and wage war on communism. ${ }^{124}$ Like the vast majority of UTC leaders, Caycedo also viewed the labor-capital relationship as a partnership: "...la UTRAL y la UTC, han creido que la mejor forma de defender los intereses de los trabajadores, es a base de la aplicación de relaciones justas, respetuosas y equitativas, donde se trabaje con la mira siempre puesta en función de empresa, entendiéndose como tal la unión del capital con el trabajo, pués el uno sin el otro no podrán marchar." 125

After the assassination of Gaitán, there was a breakdown of public authority as Liberals declared war on the Conservative government. Traditional party hatreds that had been so common in the dozens of armed conflicts of the nineteenth century again gripped the nation.

The Conservatives' social, economic and political policies were eerily similar to the laissez-faire policies the Liberals advocated throughout the second half of the nineteenth century. Fluharty, writing nearly thirty years ago commented on the Colombian Conservatives' version of trickle-down:

the masses would be benefitted as prosperity seeped down to them. Less government interference would stimulate business and production; and the government [would] create a more favorable attitude toward those who produce wealth, rather than holding them up as public enemies... The amazing assumption that workers do not produce wealth was typical of the "no-one-else-exists" view the oligarchy seems steadily to have maintained during this troublesome time...Remind the masses that the oligarchy is the source of all good-that is the basic assumption of this report.... [the oligarches] were men 'who believed it the duty of everyone to conform to

${ }^{124}$ From Reseña histórica de la UTRAL, Barranquilla, quoted in Ramos, Surgimiento, p. 13.

125Ramos, Surgimiento, p. 13. 
the station of life into which he had been born, 'and leave the management of all affairs for all classes in the hands of the privileged, enlightened ruling caste. 126

From 1949 to 1953 the nation was again convulsed by civil war, Liberals fighting against a Conservative government they claimed lacked legitimacy. In 1953, the ultraConservative government of Laureano Gómez was overthrown by the Colombian military in a coup supported by both moderate Liberals and Conservatives. By 1956, the new government had converted itself into the second military dictatorship in Colombian history, the dictatorship of Rojas Pinilla. In 1957 moderate Liberals and Conservatives again found middle ground in order to depose the caudillo. It was time, leaders of both sides argued, to resolve the historical hatred between the Red and Blue and to bring an end to the violence that threatened to maintain the nation in a state of permanent anarchy. The compromise devised by élites from the two traditional parties was the National Front, a power rotatingsharing agreement in which the party in power would include a large number of members from the opposite party in cabinet positions and in which the parties would rotate control of the presidency for a period of sixteen years. Through the vehicle of the National Front, by institutionalizing a power sharing arrangement between the Liberal and Conservative Parties in 1958 , the industrial bourgeoisie was able to decisively derail organized opposition to its preeminent position in Colombian society. ${ }^{127}$ Not until 1958 could one claim that this social group reigned ascendant.

${ }^{126}$ Fluharty, Dance of the Millions, p. 109.

${ }^{127}$ See Albert R. Berry, Ronald G. Hellman and Mauricio Solaún, Politics of Compromise: Coalition Government in Colombia (New Brunswick, New Jersey: Transaction, Inc., 1980) for an excellent series of essays on the National Front. 


\section{CHAPTER 8}

\section{CONCLUSION AND IMPLICATIONS FOR FUTURE RESEARCH}

\section{CONCLUSION}

From the Sociedades Democraticas of the nineteenth century to the Confederacion de Trabajadores de Colombia and the Unión de Trabajadores de Colombia of the present century, worker's organizations have been immersed in the partisan political battles of Colombia's two traditional parties. This study examines the genesis and subsequent growth of the Colombian labor movement during the hundred years covering the period 1848-1948. As the title of the work suggests, over this period ordinary workers - artisans, peasants and laborers - were caught up in the ideological battles between élites from the Liberal and Conservative Parties. In this struggle, artisans and rural workers paid the highest price in human and economic terms fighting for one or the other of these ideologies, neither of which workers could claim as their own. This thesis has specifically focused on the historical role various intellectual and ideological productions played in influencing men's actions in various epoches.

The study also examines the influence of foreign ideologies, to what degree they were or were not altered to fit the Colombian case. Included among the most important ideological currents affecting the political, economic and social policies and programs implemented during the one hundred years covered by the study are the profound influence of classical liberalism in the nineteenth century, socialism at the turn of the century, the influence of the communist international on the workings of the Colombian Communist Party, the impact of modern liberalism in the middle of the twentieth century and finally, the influence of fascism and ultra-conservatism on conservative thought and actions at midcentury.

The analysis presented is holistic: it is a socio-historical interpretation of the evolution of working class organization-élite relations. In an effort to provide a more objective, more complete understanding of the development of the Colombian labor movement than could be achieved through the study of historical or political events alone, special emphasis is placed on the dynamic interplay between philosophical and political ideas, ideology and empirically-observable behavior. Concurring with world systems theorist Immanuel Wallerstein's insistence on studying "the widest range of phenomena, including through all of historical time and space," in order to understand the present reality 
of any particular object of inquiry, the approach that has been adapted in the present work is one which analyzes the social, political and economic context of the historical development of Colombian labor as well as the role ideas played in serving as catalysts inspiring individuals and groups to action. The impact of ideas and ideologies on men's actions is central to the analysis presented.

In the Colombian context, Marx's assertion that the "ruling ideas of each age have ever been the ideas of its ruling class" must be considered carefully. One key variable in the development of organized labor is the gulf in power between social classes: small élite groups in Colombian society have always had a disproportionate influence in the creation and dispersion of ideas. Since it is the élite who have historically dominated the social mechanisms responsible for disseminating information - the press, parochial and public schools, and the political machinery of the two traditional parties - it is also they who have primarily controlled the socio-political content of ideas.

Elite sectors of society have enjoyed a good deal of success in employing ideas to "mask" social reality in efforts to prevent other social groups from achieving full consciousness of their own relative positions in society. Nevertheless, while it is acknowledged that the Colombian bourgeoisie have been generally successful at marketing their visions as "the ideas" underpinning society, they have never been able to completely "regulate the production and distribution of the ideas of their age."

As discussed throughout this work, "ruling" ideas were not the only ideas competing in society, and at times, during the 1930's for example, many of the ruling ideas were translated into actions that materially benefitted the working classes. Alfonso López' Revolución en Marcha was in great measure the artisan-inspired Socialist platform of 1919 writ into law. ${ }^{1}$ The following section discusses the rise to prominence of liberal ideology, its challenge by conservative ideology and the successes and limitations of its influence with rural and urban workers. In summary fashion, it retraces the major arguments made in the thesis.

Since the socio-historical analysis presented here seeks to interpret the development of labor-capital relations in the twentieth century utilizing a holistic, historical perspective, the thesis begins by exploring the legacy of colonialism in Nueva Granada. Chapter Two

\footnotetext{
${ }^{1}$ Among the Socialist planks later adopted by the Liberals were educational reform, legislation on the use of common lands; legislation providing for public housing; tax reform; retirement benefits; the fabled 8hour work day; obligatory public schooling; reform of workmen's injury laws; secularization of the nation's schools; nationalization of the army; and efforts distancing if not quite separating Church from State, and finally, modest protective tariffs on nationally produced goods.
} 
analyzes the basic Spanish pattern of colonization in Colombia, focusing special attention on the economic systems of encomienda and mita. Under the first system, encomienda, Spanish conquistadores were initially awarded the use of large tracts of land and its resources by the Spanish Crown, including royal concessions of labor by indigenous Americans in Colombia. In return, the encomenderos were charged with the defense and religious indoctrination of the native peoples, much the same as Spanish overlords in Spain had been charged with the protection of their feudal fiefs. In Spain's colonial possessions as at home, the Church and State undertook complementary missions: the state's role was to colonize new territories and teach their inhabitants to be productive citizens loyal to the crown, and the Church's mission was to convert the indigenous peoples to Christianity while looking after their spiritual and physical welfare.

By the end of the seventeenth century, the encomienda system was displaced by the mita. Mita was the system of labor recruitment of indigenous peoples under which villages provided a certain number of individuals to work for local governments or private employers for an established wage. Although in theory individuals were to work of their own free will, in practice no where in Nueva Granada was this the case. The mita was obligatory. Generally, the salaries paid were well below those which could support a family, and the system of labor recruitment forced native peoples to work away from their villages in the unhealthy gold and silver mines of Nueva Granada. ${ }^{2}$ The mita helped hasten the decline of traditional forms of communal agriculture, and contributed to the rapid decline of native populations.

As Spanish towns began to flourish in the New World, the division of urban labor became more complex. The mercantile élite established consulados, powerful corporations of export/import merchants while artisans organized cofradias, guilds that provided for members' spiritual guidance and in lean times, their social welfare. In colonial times, distinctions based on social rank and status were perhaps even more pronounced than they are today: the European-descended landowners occupied the highest ranks of society in the countryside and were paralleled by the mercantile trading élite of the cities. These were closely followed by primarily ethnic-European professionals such as journalists and physicians. The middling sectors were occupied by a predominantly mestizo artisan class, followed by mestizo campesinos. On the lowest rungs of the social hierarchy in colonial times were the indigenous peoples and below them, African slaves. Artisans, indigenous

\footnotetext{
2 When men were recruited during planting or harvest-time, this practice contributed to a particularly pronounced decline in village standards of living.
} 
labor, and slaves provided the labor which produced colonial goods, provided the workers who planted and harvested crops to feed the towns and villages, and supplied the slave labor to mine the bullion which was sent to Europe.

The American-born, "criollo" élite wrested political power from Spain in the early nineteenth century, but a fundamental transformation of society did not occur. Although the new ideological movement of liberalism transformed the way the criollo, or nativeborn, merchant élite viewed itself, despite its egalitarian and democratic rhetoric, liberalism simply did not affect a change in social and economic relations between artisans and merchants, or between campesinos and landowners. Nor did it affect changes in the social relations between whites and mestizos and native Americans, nor despite the early republican abolition of slavery, between the ruling élite and Colombians of African descent. Independence simply reflected a bloody and destructive transfer of power from continental Spaniards to a European-descended, predominantly white American-born élite. Chapters Three and Four analyze in detail the social and economic relations between classes in the nineteenth century as well as the impact of liberal and conservative ideologies on artisan production.

Despite the abiding interests of the upper class in maintaining its advantageous social position, two ideological currents divided the élite into antagonistic camps: Liberal and Conservative. Although the issues that separated the two parties were to change dramatically in the twentieth century, Liberal-Conservative conflicts defined Colombia's political landscape for nearly 150 years after the nation's independence from Spain.

In the nineteenth century, Liberals promoted the creation of a secular state by limiting the power and authority of the Catholic Church to religious affairs. They argued for a federalist form of government, believed in individualism, and promoted laissez-faire economics. Conservatives favored traditional Catholic values and a powerful role for the Church in education, health, welfare, and in social functions such as performing marriages, maintaining official birth and death records, and performing other record-keeping tasks. They also fought for a strong central government, and generally held a more strictly hierarchical view of society than did the Liberals. Conservatives believed that in society nature dictated the social plane to which each individual belonged. Conservatives were also more inclined to support protection of domestic industry than Liberals, though protection did not become an important political issue until the Núñez era.

The radical democratic rhetoric of the "Generation of '49" seduced artisans into a mid-nineteenth century alliance with the Liberal Party. This alliance had the overall effect of placing political power firmly in Liberal hands. Sermons on democracy, egalitarianism, 
individual liberty and brotherhood held a strong appeal to artisans and their individualistic work ethic. Liberal-inspired sociedades democráticas and the Conservative sociedades populares were created by party élites to propagate Liberal and Conservative ideologies. Liberals clearly garnered the bulk of artisan allegiance as a result of the party's more egalitarian, less hierarchical vision of the ideal society. Nonetheless, at mid-century the party suffered an internal division between artisans who favored protection of domestic industry, represented in the main by the Draconiano wing of the Liberal Party, and the Gólgotas, who favored unfettered laissez-faire economic policies.

Artisan sociedades mobilized to provide welfare assistance to needy members, to pursue specific electoral objectives, and above all, to oppose the free-trade policies that artisans knew were destroying domestic manufactures. By 1853, Liberal and Conservative artisans alike decisively rejected the radical liberal free-trade thesis, throwing their support behind the Draconiano candidate, José María Obando.

In general, nineteenth century artisan groups were well-organized, and were led by literate, committed artisans. By mid-century, artisans clearly had become aware of the economic and political differences between themselves and the radical Liberals. An indication of this emerging artisan class consciousness is apparent in the words of artisan leader and writer, the tailor Ambrosio López who exclaimed in 1853, "We turned aside from our main objective [that of obtaining tariff protection] and we became interested in raising to power certain men, believing that they truly loved us...but we in good faith, served only as stepping stones and today these men sacrifice us and destroy the Republic."3 The artisan challenge mounted by the Sociedad Democratica de Bogotá and General José María Melo to the Liberal élite in 1854 led to the establishment of an "Artisan Republic" which lasted for eight months. The élite response was decisive: the Conservative Party and the Radical wing of the Liberal Party put aside their ideological differences long enough for the élites of both parties to violently suppress the threat from below.

After the insurrectionary challenge to élite rule had run its course, artisan organizations adopted the role of welfare organizations dedicated to looking out for the physical well-being of their members, as well as occasionally acting as pressure groups within the Liberal Party. Most artisans continued to support the Liberals even while Liberal economic policies continued to undermine the artisans' means of making a livelihood. Less expensive European imports continued to flood unabated into the Colombian market.

${ }^{3}$ Urrutia, Development of the Colombian Labor Movement, p. 24. 
Liberals themselves were committed to a policy of economic non-intervention and nonprotection as much out of economic interests as out of ideological commitments. Most artisans, who must have believed that a worst fate might befall them in the hands of a Conservative government, continued to serve as cannon fodder for Liberal armies throughout most of the second half of the nineteenth century.

In the countryside, peasants faced a similar situation. Chapter Five, which also discusses the rise of the coffee export economy in the late nineteenth century, describes how Liberal reforms made possible enclosures of vast tracts of land, including indigenous resguardo lands that had previously been indivisible. Despite the successes large landowners enjoyed in enlarging their holdings, scarcity of work-hands was a recurrent problem for landowners throughout the nineteenth and the early twentieth centuries. While labor shortages gave peasants and colonos some leverage in terms of their struggles with large landholders, political connections with the local party in power of ten proved decisive.

Coffee had a major impact on labor relations in the countryside. Tenant farmers, who as a result of labor shortages frequently received favorable contract terms, were often permitted to cultivate and harvest coffee on small family plots to sell on the open market or to the landowner. Smallholders, in an effort to avoid proletarianization, submitted themselves and their families to ever-increasing levels of self-exploitation in order to hold on to the source of their existence as independent producers-their lands. On their small plots of land they struggled to produce corn and beans to feed their families, and devoted a great deal of energy to clearing fields, planting, harvesting and marketing their coffee. Tenants had the additional obligation of working the hacendado's fields.

The presence of the expansive, largely virgin northwestern frontier presented an attractive alternative to campesinos imbued with a strong desire to own their own land and eager to avoid becoming wage earners in the haciendas. Thousands of landless peasants, minifundistas, and even displaced artisans set out to stake their claims in the new frontier. A trickle in the second half of the nineteenth century, the migrations became a flood in the first half of the twentieth. In order to increase coffee production for export and food production for the domestic market, after 1930 Liberal governments encouraged immigration, passed legislation designed to award land titles to smallholders, and generally sought to democratize agricultural production in older regions of the nation.

The colonist movement in the late nineteenth and early twentieth century helped to make coffee production a widely dispersed, if highly unequal phenomenon. As discussed in Chapter Five, smallholders and large landowners alike benefitted from coffee. A majority of farms were small or medium-sized. Earnings from coffee exports trickled 
down to thousands of smallholders, leading to the eventual creation of a domestic market for consumer goods. From coffee-trilling machines to domestically-produced clothing, coffee was also a boon for local manufactures. Since the business was controlled by Colombians, even the export-import functions which were often controlled by large-scale coffee producers allowed significant accumulation of domestic capital. This, along with the impact of the "Dance of the Millions", attracted millions of dollars in foreign capital. This influx of capital in turn enabled the Colombian "industrial revolution" to take root between 1920 and 1960.

The widespread benefits of coffee must not be exaggerated. Elites controlled every aspect of the marketing process, and thus effectively controlled the industry. Smallholders and colonos still had to rely on the palanca they exercised with their local party patrons in order to win title disputes with large landowners and among themselves.

Elites also controlled the political parties. Party loyalties that extended from generation to generation, local patronage patterns, and frequent intra-class disputes over landownership undermined campesinos' collective efforts to resist enclosures. These factors also prevented the full development of a class consciousness of their plight. Their interests, like the artisans', also became subservient to élite interests.

After 1910, Colombian industry hegan to grow at a remarkable pace, partly as a result of import substitution made possible by foreign receipts on coffee, and partly as a result of the $\$ 25$ million windfall in the early 1920 's from the United States' indemnification for its role in the separation of Panama. While Colombia received $\$ 30$ million in direct foreign investment in 1920 , the sum had grown to nearly $\$ 300$ million per year and an additional $\$ 200$ million in foreign credits by the end of the decade. ${ }^{4}$ Expanded public works projects provided employment opportunities for thousands of unskilled and semi-skilled laborers. Import substitution policies also led to the creation of a wageearning proletariat.

Along transportation routes, in Colombia's ports and in the small foreign enclaves, the banana and petroleum industries worked the majority of wage-earners in the first decades of the century. In terms of organization, initially transport workers were influenced by the anarchists who led several strikes in the second decade of the century, including a major strike of port and river workers in 1918. Even before the creation of the Socialist Party in 1919 however, anarchist influence was primarily limited to the Caribbean coast and the Magdalena river. After the Socialist Party was founded, most anarchists were

${ }^{4}$ Oquist, Violence, p. 93. 
absorbed into its fabric, and never again played a major independent role in labor organization.

At the turn of the century, early workers' organizations in Colombia's towns and cities were strongly influenced by artisans, still the predominant form of production in urban Colombia in the first half of the twentieth century. In the first decade of this century, artisans, workers, and Liberal intellectuals created the Workers Party. At first, the new party actually served as an electoral recruiting tool for the Liberal Party, but in 1909 the Workers Party sought to chart a course independent of the Liberal Party. In 1912 the Workers Party even went so far as to support the Liberal-Conservative coalition Republican Party before later returning to the Liberal fold. Many of the early worker's organizations were unique in that they included industrialists as in the case of the Union Nacional de Industriales y Obreros in 1910 (UNIO).

Three of the most important early unions declared their insistence in maintaining a course free of partisan politics. All three ended up supporting either the Liberals or the Republican coalition. In addition to the Workers Party and UNIO, even the grass-roots Unión Obrera Colombiana (UOC), founded in 1913 as the first union to limit its membership to workers and artisans, could not manage to prevent itself from throwing its support behind the Liberal Party. Still, the UOC played an important role in the development of an organized labor movement in Colombia by raising artisan and worker consciousness of their "distinctness" from industrialists. The union also advocated a great number of socio-economic reforms, such as improved education, higher wages, and the passage of legislation guaranteeing the safety of male and female workers, reforms which would subsequently be championed by later unions and by a revitalized, reformist-oriented Liberal Party.

The period 1916-1924 witnessed an attempt by artisans and salaried workers to establish an organizational framework independent of major political party domination. Workers hoped that such an organization could effectively serve to represent the interests of the working class. A new Partido Obrero was founded in 1916. Significantly, the Partido Obrero publicly recognized the Liberal Party as its greatest competitor in the struggle to garner working class support. Its partisans understood that while the Liberal Party was reformist enough to attract workers, its real interests were dictated by the élites who politically dominated the party. The Partido Obrero and its successor, the 1919 Socialist Party of Colombia were strongly attacked by the Liberals, who claimed that their own Liberal Party was the true party of the working class. 
Dominated by artisans, the Socialist Party embodied a meliorative, Christian socialism which explicitly rejected communism and anarchy. Although it sought to represent the interests of Colombia's workers, the party did not seek the abolition of private property, nor did it advocate class warfare. Its primary goals were economic benefits for workers: better public education, better housing conditions for workers, a government sponsored literacy program, and a number of specific items such as an eight-hour work day, retirement benefits, maternity benefits, protective tariffs, legislation to curb the use of alcohol, and the separation of church and state. The Socialists were not above entering into alliances that might further their constituency's interests, but were very careful only to support candidates who advocated positions that would further workers issues in accordance with the Socialist Party's platform. The Socialists were largely successful in raising consciousness among workers and artisans as well as among leftist Liberals.

Winning many votes in urban areas, Socialist successes began to worry Liberals. The Liberal Party stepped up its diplomatic efforts to coopt the movement in order to bring Socialists and workers into the Liberal fold. In 1922 they succeeded. Socialists threw their support behind the Liberals in an effort to bring down the Conservative government. When the Liberal Party platform was drawn up, it was uncannily similar to the earlier Socialist Platform. It is not surprising that Socialist Party leaders believed that the Liberals were advocating virtually the same programs as they had been supporting. In 1924 the Socialist Party was dissolved, a large majority of its members casting their lot with the Liberal Party.

Socialists made significant inroads into the internal politics of the Liberal Party. Defecting Socialists helped write the new Liberal agenda. Nearly all of the reforms Socialists had advocated in 1919 became laws under the Liberal governments of the 1930's and 1940's. These reforms improved workers' lives in tangible ways. Nevertheless, the dissolution of the Socialist Party meant the end of efforts to create a workers movement independent of the traditional political parties, one that might be relatively free from interference by élite sectors of society. The Revolutionary Socialist Party, the radical spinoff of the Colombian Socialist Party, could never manage to convince workers that it was a viable vehicle for carrying forward the workers' struggle.

The change in orientation of the Liberal Party, its adoption of modem liberal ideology which advocated a more active state role in the economy and social life, was made possible by a change in Liberal leadership. Under Liberal governments, the conditions under which workers labored improved tremendously, despite the first shock waves of the world depression. While the pace of industrialization actually continued to quicken after 
the onset of the Great Depression, in 1929 and 1930 workers suffered deterioration in their wages much the same as their counterparts elsewhere in the hemisphere. This was the result of a near-halt in foreign investment, a plunge in world coffee prices and the general impact of the world depression itself. Fortunately for workers, there were also precipitous declines in the cost of foodstuffs and building materials. In any case, by the early 1930's the trend had been reversed.

Under the Liberal governments of the 1930's and 1940's, workers witnessed major improvements in their quality of life not only through an increase in real wages but also as a result of Liberal legislation that mandated safety standards to protect workers, set a fortyhour work week, mandated overtime pay, Sunday and holiday pay and required companies to provide severance pay. Unions were also recognized and the right to strike for better benefits was legalized. Both urban and rural workers chose to hitch their hopes and aspirations for a better life for themselves and their families to the rising and falling tides of the two traditional parties which were politically dominated by exporters, importers and large landowners. In the process, while workers prospered during Liberal rule, they prospered at the expense of their organizational autonomy. When Conservatives hostile to organized labor came to power, organized labor was simply forcefully suppressed.

A handful of other works have explored the themes of ideology and labor in Colombia, the most influential recent works among them Charles Bergquist's Labor in Latin America: Comparative Essays on Chile, Argentina, Venezuela, and Colombia and Moncayo and Rojas' Luchas Obreras y Política Laboral en Colombia. While the present study builds on these works, there are important differences.

Moncayo and Rojas in their interpretations of the ideological content of labor legislation passed during la Revolucion en Marcha argue that the Liberal governments of the 1930's and 1940's attempted to diffuse the threat to élite rule posed by those from below, the proletariat. Bergquist's analysis focuses on the threat posed to established order from rural laborers. ${ }^{5}$ While Bergquist focuses almost exclusively on rural workers and fails to explore potential ties to urban labor, Moncayo and Rojas emphasize salaried workers, ignoring labor in the countryside.

\footnotetext{
${ }^{5}$ Bergquist argues that the Liberal's primary worries were the rural workers while Moncayo and Rojas argue that a Liberal industrial bourgeoisie had ascended to power and that their perceived enemy was primarily the urban working class. See Moncayo and Rojas, Luchas, and Charles Bergquist's works, Coffee and Conflict in Colombia, 1886-1910 (Durham, N.C: Duke University Press, 1978), and Labor in Latin America: Comparative Essays on Chile, Argentina, Venezuela, and Colombia (Stanford, California: Stanford University Press, 1986).
} 
Bergquist, persuasively arguing for a more prominent place for coffee workers in Colombian labor historiography, writes the following:

In recent decades, Colombia, like the other Latin American nations, has had to adjust to a new division of labor in the world capitalist system. The decentralization of manufacturing industry in the world economy has promoted both the expansion and the denationalization of Colombian industry. With this pattern of industrial development, coffee has served as the Colombian surrogate for heavy industry. It has continued to provide foreign exchange to purchase the growing volume of capital goods and industrial raw materials needed by Colombian industry and service a foreign debt that has ballooned in the process of the nation's postwar expansion. But Colombia's relative success in pursuing this model of development has depended as well on the organizational weakness of the Colombian labor movement and the impotence of the political left. Coffee ensured that both remained minor impediments to the postwar liberal developmentalist plans of the Colombian ruling class. ${ }^{6}$

He argues further that Liberal reformers worried that workers deprived of land in the countryside contributed to a chronic state of social tension that could possibly lead to open conflict. Violent, class war, could in turn endanger capitalist development of the country. Bergquist writes, "the body of labor law perfected between 1930 and 1945 sought to eliminate the revolutionary potential of these workers and reduce conflict in industrial relations." 7

While agreeing that one outcome of the labor legislation enacted during the period was to reduce the possibilities of violent class conflict, to argue that this was the overriding goal of the Liberal reformers, as do Moncayo and Rojas, overlooks the significant influence that socialist ideas played in the social formation of the reformers themselves. True, it was in the interests of the élite to reduce the potential for labor conflicts both in the city and in the countryside, but accommodation and compromise was not the only élite avenue for control of labor. After 1946, the Conservatives adopted another option, suppression, and arguably did a much more effective job of controlling labor than did the Liberals with their reform-oriented Revolución en Marcha.

Rather than create pawns that the Liberal Party leadership could shrewdly manipulate to advance their own class' economic interests, most party reformers genuinely viewed labor as a partner to capital, a partner that had been unjustly compensated for its

${ }^{6}$ Bergquist, Labor, p. 310.

${ }^{7}$ Bergquist, Labor, p. 348. 
contributions to the productive process. Liberals sought to pass legislation that would bring labor a greater share of society's wealth. Although labor never became an equal partner with agro-export capitalists such as Alfonso López himself, as became clear from subsequent events under the Liberal government of Camargo and the Conservative governments which followed him, to argue that the Revolución en Marcha was a carefully planned élite conspiracy solely designed to diffuse a potentially radical labor movement is in effect re-interpreting history to conform to a particular ideological perspective. ${ }^{8}$

Virtually ignored by Rojas and Moncayo is the fact that workers realized many tangible bread-and-butter gains during the Liberal hegemony. These included higher wages, safer working conditions, improved benefits, and significantly, the right to organize. These gains were an essential component of the Liberal reforms of the 1930's and 1940's. One could plausibly argue in fact that these were the primary goals of Colombian liberalism, based on the Liberals' understanding of how to go about the business of constructing the 'good society'. Although the labor movement did indeed become channeled into mainstream Liberal politics, whether or not labor had had any 'revolutionary potential' before the mid-1940's is highly debatable, especially in light of the socially conservative nature of all the major, artisan-dominated labor organizations before mid-century.

Given the benefit of historical hindsight, while it could plausibly be argued that Conservatives perceived a strong threat from both rural and urban workers, a threat that urgently needed to be eliminated, it is much less convincing to argue that the ex-socialists, social-welfare oriented Liberals and labor activists who comprised the vanguard of the Liberal reform movement viewed workers with the same distrust as Conservatives. Liberals in fact looked forward to welcoming workers into a progressive alliance that had the potential of toppling the 'reactionary' Conservative government. When the Conservatives assumed political power in 1946, they set about the task of dismantling many of the labor reforms undertaken by the Liberals, in the process demonstrating that repression and overt cooptation (as in the case of the creation of the Catholic-inspired UTC) was as effective as reform in controlling the laboring classes.

On the other hand, Liberals did undoubtedly wish to limit the influence of the Communist Party among workers and working class organizations. This fact probably had a strong impact on writers such as Moncayo and Rojas in their analysis of the intent and ideological content of labor legislation during the Revolución en Marcha. However, the

\footnotetext{
${ }^{8}$ This is the central argument advanced by Moncayo and Rojas, Luchas Obreras y Politica Laboral.
} 
Communist Party too hoped to limit the Liberal Party's influence on workers, believing, as did the Liberals, that it was the appropriate vehicle for expressing working class interests. Here one must be careful not to make the egregious error of uncritically assuming that the Communist Party represented the true interests of urban or rural workers, and therefore reason that Liberal attempts to curb the power of the Communists were tantamount to efforts to coopt working class organizations.

Another point on which the present work differs from works by authors such as Moncayo and Rojas, Fals Borda, Cesar Mendoza Ramos and Ricardo Sanchez is in the argument that the period explored does not witness the consolidation of power by the industrial bourgeoisie. ${ }^{9}$ The industrial bourgeoisie may as Rojas and Moncayo argue, have been in the ascendancy, but it is difficult to accept the proposition that by the 1930's they had consolidated their class hegemony.

First, although Bergquist clearly recognizes this fact, writers such as Moncayo and Rojas fail to understand the importance of rural labor in the overall picture of labor in Colombia. Not until the 1960's were the majority of the nation's citizens urban-dwellers, and in the period in which Moncayo and Rojas claim that the industrial bourgeoisie had gained the reigns of power, between 1930 and 1945, only one-third of the nation's people lived in urban areas. The following table shows the trend of urbanization in the twentieth century.

${ }^{9}$ Each of these writers make the basic argument that the industrial bourgeoisie consolidated its power during the 1930's. See, Orlando Fals Borda, Subversion and Social Change in Colombia (New York, London: Columbia University Press, 1969); Cesar Mendoza Ramos, Surgimiento y Desarrollo de la Clase Obrera en Barranquilla, paper presented at the Third Congress of Colombian History, Universidad de Antioquia, Medellín, Colombia, (November, 1981), and Ricardo Sanchez, Historia Política de la Clase Obrera en Colombia (Bogotá: Editorial la Rosa Roja, 1982). 
TABLE 8:1

Total Urban-Rural Population

1918-1973 (thousands)

\begin{tabular}{lccccc}
\hline Year & $\begin{array}{c}\text { Total } \\
\text { Population }\end{array}$ & Urban & $\%$ & Rural & $\%$ \\
\hline 1918 & 5,956 & 1,231 & 21 & 4,625 & 79 \\
1925 & 6,724 & 1,560 & 23 & 5,164 & 77 \\
1930 & 7,425 & 1,934 & 26 & 5,491 & 74 \\
1938 & 8,702 & 2,502 & 29 & 6,200 & 71 \\
1945 & 10,152 & 3,447 & 34 & 6,702 & 66 \\
1951 & 11,589 & 4,662 & 40 & 6,927 & 60 \\
1953 & 12,111 & 5,177 & 43 & 6,934 & 57 \\
1964 & 17,484 & 9,240 & 53 & 8,244 & 47 \\
1973 & 20,785 & 12,489 & 65 & 7,868 & 35 \\
\hline
\end{tabular}

Source: ECLA census data compiled by Medofilo Medina, Anexo 4, La Protesta Urbana, p. 208.

This in itself is not sufficient evidence to demonstrate that the urban bourgeoisie had displaced landholders and agro-exporters as the leaders in the nation's social and political affairs. In order to determine the plausibility of the thesis that the Revolución en Marcha represented the ascent to power of an industrial bourgeoisie, one can look at the state of development of Colombian industry at the time as well as the Liberal government's relations with agro-exporters.

One problem with Moncayo and Rojas' interpretation, as mentioned in Chapter Seven of this work, is that sufficient evidence that the export sector and López were at odds, even less so the Liberal governments of Herrera or Santos, is not offered. ${ }^{10}$ Although the Federación de Cafeteros opposed import substitution programs on the grounds that they constituted a poor use of scarce capital resources, and the conservative Asociación Patriótica Económica Nacional (APEN) stood against the agrarian reform, on the whole, the industrial bourgeoisie and the agro-exporters were not antagonistic. Many of the Liberal reformers' families were themselves agro-exporters and it was coffee exports that had made industrial growth possible in the first place. Commenting on the growth of the financial resources of the Federación de Cafeteros, Pecaut argues along the same lines: "Se comprenderá pues la importancia que adquirieron los debates desarrollados entre este sector y el gobierno durante la administración de López. Pero en ningún momento se trata

\footnotetext{
${ }^{10}$ As mentioned numerous times above, López and other Liberal reformers were themselves coffee exporters.
} 
de un sector en crisis que se enfrenta a un gobiemo cuya divisa es la de lograr intervenir en la política cafetera." 11

In the Colombian case, the differences between exporters and industrialists were not profound ones: industrialists depended on foreign coffee earnings and the concomitant rise in smallholder income to help create domestic demand for goods made in Colombia. Rather than view industrialists and agro-exporters as adversaries, it is much more accurate to speak of a sometimes uneasy partnership between them that was frequently colored by rivaling self-perceptions. ${ }^{12}$

Perhaps the most critical variable missed by Moncayo and Rojas was the rather unrevolutionary, individualistic nature of the majority of Colombia's workers themselves, both urban and rural workers. Even Bergquist fails to see the significance of the socially conservative nature of the artisans. At the time of the Revolucion en Marcha, most urban workers were still artisans. The early labor movement was permeated by the conservative values of artisans in Colombia's towns and cities and campesinos in the countryside. Of central importance to campesino and artisan alike was a desire to own their own means of production, as I have discussed throughout the thesis.

Many farmers in the twentieth century who migrated to Colombia's cities and the frontier regions had once owned their own property, and did not immediately lose their dream of owning their own means of production. As has been amply demonstrated in Bergquist's excellent works on the Colombian coffee industry, thousands of colonos and landless peasants sought support from their political parties and their local party patrons in their conflicts with each other as well as in their tireless struggles to obtain land titles against the claims of large landowners. This desire to be master over ones own work meant that colonos and smallholders did not easily lend themselves to organization by leftist groups advocating communal forms of agricultural organization.

After La Violencia began, immigration to the cities increased. While two-thirds of the nation's population lived in the countryside in 1945, by the mid 1960's after the worst effects of La Violencia had already been experienced, less than one-half Colombia's

${ }^{11}$ Daniel Pecaut, Politica, p. 119.

${ }^{12}$ When they were not engaged in export themselves, long-established landed families sometimes viewed themselves as somewhat socially superior to those involved in export-import. Both groups initially looked upon themselves as superior to industrialists, linking this group to its artisan forerunners. Some artisans in fact do seem to have made the transition from artisan to industrialist. See David Sowell, "The Early Latin American Labor Movement: Artisans and Politics in Bogotá, Colombia: 1832-1919, (Ph.D. Dissertation University of Florida, Gainesville, Florida, 1986). 
citizens were rural dwellers. ${ }^{13}$ A large part of this influx came from the hundreds of thousands of parcelas abandoned during La Violencia (See Table 8:2).

TABLE 8:2

Parcelas Abandoned During La Violencia, 1946-1966 by Department

\begin{tabular}{lc}
\hline Department & $\begin{array}{c}\text { Parcelas } \\
\text { Abandoned }\end{array}$ \\
Valle & 98,400 \\
Tolima & 54,900 \\
Cundinamarca & 50,400 \\
Santander del Norte & 38,400 \\
Antiguo Caldas & 36,800 \\
Huila & 27,100 \\
Santander & 26,600 \\
Boyacá & 26,400 \\
Antioquia & 16,200 \\
Cauca & 3,000 \\
All Other & 14,648 \\
\hline
\end{tabular}

Source: Oquist, Violencia, Table 6:4, p.323.

Much of the abandoned land was claimed by powerful landowners, continuing a process of enclosures that had begun in earnest in the closing decades of the nineteenth century and which continue through the present day. The impact that rural laborers who had been deprived of their lands had on the urban labor movement is an area which merits much further research. At the very least, it is not implausible to believe that their individualist work ethic complemented and reinforced the individualist work ethic of the urban artisan, and made them much more receptive to modern liberal ideological proselytizing.

Despite the enclosures, violence in the countryside, and the changing agrarian and labor policies of the two traditional parties, campesinos have never lost their desire to own their own land. A questionnaire-based study conducted by Marxist scholar Nicolás Buenaventura of migrant workers in the mid-1970's found that 39 percent of those polled had once been owners of a small farm. Sixty-one percent responded that their fathers had been small landholders, while only 12 percent said that they presently owned their own

${ }^{13}$ Medofilo Medina, La Protesta Urbana, p. 208. Between 1964 and 1973 the rural population actually declined from 8.2 million to 7.9 million as a result of migration to the large cities. 
land. ${ }^{14}$ More than three-fourths responded that they hoped one day to acquire a small farm or business so that they could escape migrant work ${ }^{15}$ and 84 percent of those chose a small farm over a business. ${ }^{16}$ One of the most telling responses, disappointing as it must have been to its Marxist author, was that an overwhelming majority of those questioned ( 92 percent) believed that the land would produce better if it were organized in a different way, 70 percent of these responding "it would be better divided up into family-owned farms" and only 30 percent responding that it would be best "organized into cooperatives or community enterprises." 17

As mentioned above, Colombian campesinos, proud of their status as independent producers, were not ready clients for Marxist or other collective-advocating organizers. This had consequences for rural laborers' struggles in the countryside, a point which has been noted by Bergquist:

Inexorably, however, as [rural workers] progressed toward their goals, they abandoned the collective strategies that won their early victories. At great cost to themselves and to their society, the collective struggle of workers in coffee production degenerated into private, individual affairs sanctioned by traditional politics. The transformation of their struggle inevitably turned coffee workers against one another. After mid-century it left their class oppressors free to forge a new ideological and political consensus and successfully consolidate an industrializing peripheral capitalist order...in winning the battle for the land, these workers in coffee production thus lost the struggle to transform the exploitative capitalist society in which they labored. They helped instead to modernize that society, and to reinforce the liberal values and institutions on which it rested.

By looking at the stage of industrial development achieved by Colombia in the 1930 's, one cannot help to note another important variable that Bergquist and Moncayo and Rojas' works ignore; that artisans still played a predominant role in labor organization in the 1930's. Consider the following statistics. Despite the questionable quality of census data, even approximate estimates present clear trends for the 1938 census: 450,000

${ }^{14}$ This information is from Nicolás Buenaventura's "Proletariado agrícola, 'temporeros," Estudios Marxistas, 9 (1975) is cited in Bergquist, Labor, pp. 372-374.

15 Bergquist, Labor, p. 373.

16Bergquist, Labor, p. 373.

17 Bergquist, Labor, p. 374. 
individuals worked in la industria which also included artisan industry. ${ }^{18}$ Of these workers, an astonishing 80 percent were classified as artisans (working in establishments with fewer than five individuals). Based on this data, Pecaut estimates that no more than 80,000 to 100,000 workers could have been considered wage earners working in modern industry, most of these holding jobs in textiles, beverages, cement and tobacco, a high percentage of these workers women. Pecaut offers the following estimates for 1938: in the textile industry, 24,125 workers; in tobacco, 10,167; in the beverage industry, 6,358 and in cement and affiliated products, 1,861. ${ }^{19}$ As these numbers indicate, 1938 urban Colombia was still the milieu of the artisan.

Organizational activities undertaken by artisans earlier in this century and throughout the last, are important foci of this work. Artisans shaped the programmatic direction of labor groups throughout the first decades of this century, and artisans were the most influential voices in the early socialist movement. The strong influence they had in Socialist and workers organizations has been discussed in Chapters Six and Seven.

Liberals were quite successful in efforts to inculcate artisan loyalty to the state and to the Party. ${ }^{20}$ Conformity seemed to come cheaply. Artisans believed in equality, which only the Liberals preached. They shared the Liberal élite's view of the importance of education, though Liberal concern in the nineteenth century seldom ran deeper than the party's rhetoric. Artisans also viewed themselves as the productive force of society, holding a strong individual work ethic born of their highly individualistic craft occupations. They owned their means of production, and placed incalculable value on their status as independent producers. Liberal ideology seemed to embody these values. The Conservatives, on the other hand, did not possess an ideology capable of capturing the imagination or loyalty of workers. Their hierarchical view of society contrasted sharply with the Liberal ideals embodied in the expression liberty, equality, and brotherhood.

While the disparity of political power is a key variable in explaining why artisans generally went along with Liberal Party politics, it also may be the case that the artisans' compelling interests in tariff protection were partially obscured by the ideologizing effects of liberalism, of "lalse consciousness" in the Marxian sense. In any case it is clear that

${ }^{18}$ The following numbers for 1938 census data appear in Pecaut, Politica, p. 115.

${ }^{19}$ Daniel Pecaut, Politica, p. 115.

${ }^{20}$ Both sought to inculcate precepts of loyalty and conformity. 
after 1854 , artisan economic and political interests were completely subservient to the ruling caste.

Even under the government of Rafael Núñez, whose own ideological vision of society led him to favor mildly protectionist legislation, artisan protests in Bogotá in 1893 were violently suppressed. Artisans were nonetheless relatively more successful as a pressure group under this government. Here too the deciding factor was political power. Only because the Regeneration supported artisans and favored protecting domestic production was legislation passed that "responded" to artisan concerns. Reforms flowed from the top-down.

While élite liberal ideology may have helped obscure artisan and peasant class interests, it is argued in the thesis that Colombian history is replete with examples of classes acting in a manner contrary to their economic and political interests, including the nation's élite. In the nineteenth century, a commercial bourgeoisie and large landowners held in common a shared culture, a shared "way of life". They attended the same social clubs, studied at the same schools, were married in the same churches, ate the same kinds of food prepared by their servants, and generally enjoyed a social status well above the common crowd. Although they possessed a consciousness of themselves as a class apart, they were divided along lines of two competing, antagonistic ideological systems.

Real differences in world views divided Conservatives and Liberals: each side held opposite views on the role of the Catholic Church in Colombian society, on the value and applicability of laissez-faire economics to the Colombian case and on the relative merits of federalism vs. a strong central government. These substantive differences led to numerous violent civil wars during the nineteenth century, culminating in the bloody War of a Thousand Days at the turn of the century. Costly both in terms of wealth and lives, these conflicts were contrary to élite interests, yet persisted throughout the nineteenth century and flared up again in the middle of the twentieth. Religion and the social and political role of the Catholic Church continued to be a particularly volatile issue in both centuries, despite major changes in liberal and conservative ideologies. While such issues divided élite sectors of society, as was argued in Chapter Seven, they also divided partisans from the middle classes, artisans and workers.

The ruling classes were also vulnerable from threats below, as in the Melo threat in the nineteenth century or the socialist challenge in the twentieth, as a result of the absence of a full consciousness of their dominant role in society. It has been argued in the first two chapters that profound differences in views of what constitutes the ideal society divided Liberals and Conservatives and that "ideological" struggles between Liberal and 
Conservative élites hindered them from achieving a full consciousness of their dominant position in society.

While the two predominant élite groups divided by competing ideological systems failed to achieve complete consciousness of their position in society, at various times, both artisans and peasants achieved a surprisingly high degree of consciousness of their differences from the élite sectors of society. ${ }^{21}$ There were many examples from early Colombian labor history where artisans and rural workers alike achieved a partial consciousness of their relative position in society. While the mid-nineteenth century artisans chose to support Melo to fight for the continued existence of their position as independent producers in society, the same class later threw the bulk of its support behind a Liberal Party which pursued political and economic policies that were rapidly eroding the position of artisans in Colombian society. Later they supported the moderate Conservative governments of Rafael Núñez and Rafael Reyes who at the very least provided modest tariff relief. By this time the artisan system of production was in decline: while Núnez' reforms undoubtedly were at least partially targeted at providing protection of craft goods, Reyes was much more interested in promoting the growth of industry rather than protecting artisan production. Thus throughout the period covered by this study, even among working class leaders, an evolving "working class consciousness" was permeated with ideological elements imparted by history and by the élite

The consciousness achieved by artisans, campesinos, and salaried workers often translated into isolated struggles of groups of workers to achieve economic goals, but rarely in Colombian history has it led large segments of the working class to mount a challenge to the established political system. ${ }^{22}$ Even the peripheral Communist Party, led by intellectuals rather than workers, was an unqualified failure in raising proletariat consciousness and funnelling it into either revolutionary or sustained political action. While many artisans and salaried workers in the twentieth century were aware of their distinctness as social classes, they could never buy into the idea that the intellectual, journalist-led Communist Party was a relevant vehicle or a legitimate alternative for representing their political and economic interests. Far, far better to place their hopes in a welfare-oriented, evolving Liberal Party that might actually have the power and the will to improve their material conditions. The labor movement sought refuge in increased

${ }^{21}$ Chapter Five discusses class consciousness and the artisans in extensive detail .

${ }^{22}$ This does not include the notable exceptions of the Melo coup in the nineteenth century and the artisandominated, moderate, reformist Socialist Party in the twentieth. 
government protection under the Liberals, ultimately at the expense of expanded government regulation and control.

However true this may be, as argued earlier, though ideologies can often obscure real interests (false consciousness), they cannot long be accepted as truth unless something substantive in them can appeal to individual's economic, social or political interests. This is why the individualism, profit motive and thetoric of equality and liberty, central tenets of liberalism, achieved wide appeal among Colombian workers while socialized production and social solidarity of communism did not. The scholar's role should be to look at the ideas in society that influence men's and actions, seek out their social origins, and weigh their relative impact on individuals' lives and society as a whole, and in each case, strive to pinpoint the "masking effect" they may have on obscuring individuals' true interests. This is precisely the goal that the present work has strived to achieve.

\section{IMPLICATIONS FOR FUTURE RESEARCH}

The research conducted to produce One Hundred Years of Servitude; the Colombian Labor Movement 1848-1948 was primarily based on published materials, including government legislation, Memorias of government officials, as well of course of the voluminous secondary literature on politics and history. It is to some degree a traditional exercise in labor historiography, with a strong emphasis placed on the role of unions, parties and political elites. The study is a mid-level, national analysis, though it certainly points to important implications for the nation's full insertion into the world capitalist economy in the early twentieth century as a result of the rise of the coffee economy.

A structuralist approach which explored the social, political, and economic ramifications of Colombia's insertion into the world capitalist economic system could be profitably employed to deepen our understanding of the development of Colombian labor. Such an approach would look at the linkages between the development of the export economy, Colombia's ties to the developed economies of the north Atlantic, and the relations between élites in the "core" countries and Colombia.

Although foreign economic interests did not play the dominant role as did the foreign banana companies in Honduras, ${ }^{23}$ the major influx of foreign capital during the

23 By the 1950's seventy percent of export revenues were earned from the sale of tropical fruit, and over eighty percent of the business was in the hands of U.S. corporations. See James Dunkerley's, Power in the Isthmus: A Political History of Modern Central America (London, New York: Verso, 1988), p. 191. 
Dance of the Millions had the effect of integrating Colombia more completely as a player in the world capitalist economic system. Additionally, as a result of economic "desarrollo hacia afuera," based primarily on coffee exports, structural differences have arisen in the patterns of industrialization in the "Core" or "Center" countries of the North Atlantic and the "Periphery" or "Non-core" nations of the "South," nations such as Colombia. "Dependency" and "World Systems Theorists" such as André Gunder-Frank, Fernando Cardoso, Theotonio Dos Santos and Immanuel Wallerstein have long argued that historically-conditioned patterns of development in the "underdeveloped" nations of the world have forced poor countries into occupying the inherently inferior role of raw materials/primary export producers in a world capitalist system from which, under the present economic system, there is no escape. Because of the structural constraints imposed by a global economic order, there is no possibility for economic and social development in the underdeveloped world. ${ }^{24}$

The primary value of a structuralist, comparative approach are the heuristic benefits to be reaped from placing labor and Colombia into the world context of which both are a part. A structuralist approach, in short, could provide a macro-framework to study Colombian labor, in the process building on the essentially mid-level approaches taken by Bergquist, Sowell and the present work. While such an approach might usefully be applied to the study of Colombian labor, particularly for comparative purposes, it should be employed to complement, rather than supplant, a mid-level approach. Only a mid-level

${ }^{24}$ On dependency theory see Andre Gunder Frank, "Sociology of Development and Underdevelopment of Sociology," Dependence and Underdevelopment (New York: Monthly Review Press, 1971); Fernando Henrique Cardoso and Enzo Faletto, Dependency and Development in Latin America translated by Marjory Mattingly Urquidi, (Berkely, Los Angeles, London; University of California Press, 1979); Theotonio Dos Santos, "The Structure of Dependence," Readings on U.S. Imperialism (Boston: Sargent, 1971); Surendra J Patel, "The Technological Dependence of Developing Countries," The Journal of Modern African Studies, Vol. 12 No. 1, (1974). For good introductory overviews of dependency, see Harry R. Targ, "Global Dominance and Dependence, Post-Industrialism, and International Relations Theory," International Studies Quarterly, Vol. 20, No. 3 (Sept. 1976) and Carlos Johnson, "Dependency Theory and the Processes of Capitalism and Socialism," Latin American Perspectives, Vols. 30 \& 31, No. 384 (1981). On "world systems theory" see Immanuel Wallerstein's The Modern World Systen I (New York: Academic Press, 1974), "The World Capitalist System," Comparative Studies in Society and History, Vol. 16, (Sept. 1974), and his later work The Modern World System II: Mercantilism and the Consolidation of the European World Economy, 1600-1750 (New York: Academic Press, 1980). For critiques of dependency theory, see James A. Caporaso, "Dependency Theory: Continuities and Discontinuities in Development Studies," International Organization. Vol. 34. no. 4 (Fall 1980), and David Ray, "The Dependency Model of Latin American Development: Three Basic Fallacies," Journal of Inter-American Studies and World Affairs, Vol. 15, no. 1 (1973). For a general crilique of Wallerstein and world system theory, see Peter Worsley, "One World or Three? A Critique of the World System Theory of Immanuel Wallerstein" in David Held ed. States and Societies (New York \& London: New York University Press, 1983). 
approach can take into account specific variables in the economic and social development puzzle which may be unique to the Colombian case.

One major difference between Colombia and other cases, for example, is the surprisingly small sums of foreign capital investment made in the nation's primary export earner-the coffee industry. Production and marketing in the coffee business remained in Colombian hands, and production was widely, if unequally distributed among smallholders and large landholders. The export functions rested firmly in the hands of a national trading elite. Coffee in turn was the primary source of capital formation in Colombia. While much foreign capital entered the country in the 1920's, the majority of industry and agriculture remained firmly in the hands of domestic capitalists.

In another example of a limitation of generalizing too broadly in order to make reality fit theory, it is sometimes assumed that the nations of the underdeveloped world possessed a weak artisan tradition. ${ }^{25}$ While Colombian artisans may have lacked the militancy of their European counterparts after having suffered through the mid-nineteenth century Melo debacle, as the thesis has argued, their presence was strongly felt in labor organization at least through the first three decades of the twentieth century. The artisan milieu continued to be the predominant form of urban labor through the middle of this century before finally being displaced by a salaried proletariat.

Nevertheless, another important variable that lends weight to the idea of a complementary macro-level structural analysis is the fact that the primary income generator in the critical epoch of the formation of an urban labor movement, coffee, was produced for foreign markets and subject to the vicissitudes of developed-world demand. Also important, but to a much lesser degree, were the small enclave economies of banana and petroleum production, both of which played a much more limited role in the development of Colombia's economy and in the formation of the Colombian working class.

While the present work has begun to explore the process of proletarianization of artisans and rural laborers, as Thomas E. Skidmore has suggested, Latin American labor history, and in this specific case, Colombian labor history, could greatly profit from a socalled "bottom-up" analysis in which special emphasis is placed on worker's

25. In their comparisons between the development of the working class in Europe and Latin America, this is one of the arguments advanced by Michael Hanagan and Charles Stephenson, Proletarians and Protest: The Roots of Class Formation in an Industrializing World (New York, Westport. Connecticut, London: Greenwood Press, 1986), pp. 15-18. 
perspectives. ${ }^{26}$ Such an approach, argue Szuchman and Sofer in another work, sees social history as "a historical framework that emphasizes the inclusion of ordinary men and women into the historical process, and attempts to approximate their perspectives on that process...Thus, examining ordinary people from their perspective affords us the opportunity to reconstruct an alternate world view-the one belonging to the historically anonymous." 27

In terms of this study, segments of artisan-produced newsletters, portions of published works by literate artisans, the public positions of the artisan-dominated Socialist Party and newspaper accounts were consulted in an effort to discover worker perspectives. A careful appraisal of artisan perspectives has reinforced my belief that artisans were not merely passive actors whose true interests were completely obscured by the blinding effects of élite ideologies, though as argued above, ideology did play a role. In terms of rural workers, the author had limited access to primary resources. Instead secondary resources based on primary research conducted by Gloria Gaitán, Bergquist, Moncayo and Rojas, and Marco Palacios were extensively consulted. Although the bottom-up perspective is shared by the author, unfortunately, several limitations precluded a rigorous examination of Colombian labor history along such lines.

First, there exists a dearth of historiographical literature of this nature specifically devoted to Latin America. Although some preliminary work has been done in this area on Chile, Argentina and Brazil, monographical treatment (or for that matter, to the author's knowledge, any treatment) of the Colombian case utilizing a "bottom-up" perspective, is non-existent. As discussed in the introduction, a number of works have been written by Communist authors eager to champion the interests of the working class. Scholarly works written by the proletariat's vanguard do not however in themselves constitute a bottom-up perspective. Medofilo Medina has written a series of essays ${ }^{28}$ inspired by Rudé's works on the revolutionary crowd, ${ }^{29}$ but while he skillfully mines the legislation passed during

${ }^{26}$ See Thomas Skidmore's essay, "Workers and Soldiers: Urban Labor Movements and Elite Responses in 20th Century Latin America," in Elites, Masses and Modernization in Latin America (Austin: 1978).

${ }^{27}$ E. Sofer and Mark Szuchman, "City and Society: Their Connection in Latin American Historical Research," Latin American Research Review, XIV:2, pp. 113-129 (1979), pp. 113-114.

28 Medofilo Medina, La Protesta Urbana en Colombia en el Siglo Veinte (Bogotá: 1984).

${ }^{29}$ George Rudé, The Crowd in the French Revolution (Oxford: 1959). 
the liberal Revolución en Marcha for its ideological content, his work does not incorporate the perspectives of workers.

The closest attempts to date to write histories that incorporate workers' perspectives include the aforementioned studies by Sowell and Bergquist. Sowell spent a good deal of time sifting through newspapers, laws, flyers produced by Bogotás craftsmen, and other historical accounts to piece together his doctoral dissertation on artisans in the capital. Bergquist worked with Colombian campesinos while serving as a Peace Corps volunteer in the 1960's, affording him special insight into life in the campo and specifically into the conditions under which smallholders produce coffee. First-hand experience complemented by extensive archival work, pouring over original government documents, census records and parish documents, and laboriously reviewing contemporary newspapers, pamphlets and other print materials produced by workers yield important clues about the lives of workers in the early twentieth century. Conducting this type of intensive primary research can help to piece together the story of the historically anonymous by providing information on births, baptismals, deaths, marrying, moving, and acquiring or selling property.

Ideally, a bottom-up approach should also take into account the influence of rural worker's ideologies on the growth of an urban proletariat. To understand how rural ideologies influenced urban workers or vice versa, one would have to analyze the patterns of migration from country to city. As argued by Michael Hanagan in his introduction to Proletarians and Protest, "In order to understand the circumstances under which political influences moved from country to city or the reverse, it is necessary first to explore the links by which workers moved to the industrial city, or the mechanisms through which they were recruited to urban industrial works." 30 Unfortunately, while works such as McGreevey's article "Urban Growth in Colombia," have begun to look at general trends in rural-urban migration, significant demographic data for variables such as migrant composition during the major migrations that took place in the first half of the twentieth century has yet to be unearthed. ${ }^{31}$ This underdeveloped area of labor studies demands much fuller investigation.

By more carefully identifying who urban migrants were, one is in a much better position to explore urban links to the countryside and to understand more accurately the development of urban working class consciousness. I suspect for example that among

${ }^{30}$ Hanagan and Stephenson Proletarians and Protest, p. 5.

${ }^{31}$ William Paul McGreevey, "Urban Growth in Colombia," Journal of InterAmerican Studies and World Affairs, Vol. 16 No. 4 (November 1974). 
migrants who hailed from coffee growing regions, the "moral economy" thesis has little application to the Colombian case. ${ }^{32}$ Any idealized past life in the countryside brought by migrants to their new urban environment would have to stretch reality beyond recognition: coffee production in the countryside was a highly competitive, individualist occupation, not a peaceful, communal existence. In the Colombian case, idyllic recollections of the countryside by both migrants and élite conjures up memories of the widespread benefits of the coffee economy shared by smallholder and large landholder alike. The image evoked is one of a smallholder democracy in which individual farmers grew corn and beans for their own consumption needs and grew coffee to augment their income. As I have argued above, it left the Colombian peasantry more susceptible to capitalist ideology that held out the promise of land than to communist ideology that offered a communal way of rural life. With the exception of the resguardos, native communal forms of social life, if such a way of life ever existed among the majority ladino population, did not exist in the small coffee farms of Colombia. Such images would seem to be alien to the collective memory of a peasant-become-salaried worker.

The author hopes that this study has provided an interpretive framework capable of elucidating some of the most critical elements in the early development of the Colombian labor movement. It looks at the complex interplay of variables such as geography, regionalism, religion, the colonial legacy and the persistent influence of the political party structure inherited from the nineteenth century. By utilizing an interdisciplinary, holistic analysis which incorporates economic, historical, political, and sociological factors, the study has explored the relationship between élite ideologies, the social evolution of artisan and peasant consciousness, and action.

While the study posits that élite interests played a commanding role in both the construction of the dominant culture and the regulation of relations between social classes, it recognizes that the culture constructed by the élite was never completely dominant. An élite itself divided between two competing ideologies until after La Violencia, artisan and peasant modes of production themselves helped forge certain cultural attributes and attendant value structures independent of élite forms of cultural expression. Working class forms of cultural expression that challenge the ruling versions have not been systematically

\footnotetext{
32Moral economy refers to workers' efforts to use "moral terms of rural culture to forge a critique of urban industrial capitalism." See the discussion by Hanagan and Stephenson on the application of the concept in their introduction to Proletarians and Protest, pp. 4-18.
} 
articulated. In terms of lahor relations in Colombia during the nineteenth and the twentieth centuries, working class interests have been subservient to élite interests. 


\section{BIBLIOGRAPHY}

Alba, Victor. Politics and the Labor Movement in Latin America. Stanford, California: Stanford University Press, 1968.

Archila, Mauricio. El Sindicalismo Visto Por Algunos Teoricos del Marxismo. Documentos Ocasionales, Number 34, CINEP, March 13, 1986.

Baily, Samuel L. Labor, Nationalism and Politics in Argentina. New Brunswick, New Jersey: Rutgers University Press, 1967.

Barco, Virgilio. Lucha Partidista y Política Internacional. Bogotá: Carlos Valencia Editores, 1981.

Bazant, Jan. A Concise History of Mexico: from Hidalgo to Cárdenas 1805-1940. Cambridge, England: Cambridge University Press, 1979.

Berger, Peter L. and Thomas Luckmann. The Social Construction of Reality: A Treatise in the Sociology of Knowledge. Garden City, New York: Doubleday and Anchor, 1967.

Bergquist, Charles W. Coffee and Conflict in Colombia, 1886-1910. Durham, N.C: Duke University Press, 1978.

Labor in Latin America: Comparative Essays on Chile, Argentina, Venezuela, and Colombia. Stanford, California: Stanford University Press, 1986

Berry, Albert R. , Ronald G. Hellman and Mauricio Solaún. Politics of Compromise: Coalition Government in Colombia. New Brunswick, New Jersey: Transaction, Inc., 1980.

Blanchard, Peter. "The Recruitment of Workers in the Peruvian Sierra at the Turn of the Century: The Enganche System," Inter-American Economic Affairs, 33 (3), 1979, 63-83.

Burns, Bradford E. "Ideology in Nineteenth-Century Latin American Historiography," Hispanic American Historical Review. 58 (3), 1978, 409-431.

Burns, Bradford E. and Thomas J. Skidmore. Elites, Masses, and Modernization in Latin America, 1850-1930. Austin, London: University of Texas Press, 1979.

Caporaso, James A. "Dependency Theory: Continuities and Discontinuities in Development Studies," International Organization. Vol. 34. no 4, Fall 1980.

Cardoso, Fernando Henrique and Enzo Faletto. Dependency and Development in Latin America. Translated by Marjory Mattingly Urquidi. Berkely, Los Angeles, London: University of California Press, 1979.

Clough, Shepard B. et al. European History in a World Perspective: Volume I. Lexington, Massachusetts: D.C. Heath and Company, 1975. 
Clough, Shepard B. et al. European History in a World Perspective: Volume II. Lexington, Massachusetts: D.C. Heath and Company, 1975.

Córdoba, Marco A. Elementos de Sindicalismo. Bogotá: Ediciones Tercer Mundo, 1984.

Confederación Sindical de Trabajadores de Colombia. Bananeras 1928-1978. Bogotá: Ediciones Alcaraván, 1978.

Cuellar, Diego Montaña. Patriotism Burgués, Nacionalismo Proletario. Bogotá: Ediciones La Chispa, 1976.

Curry, Curtis D. The Catholic Church in Colombia: Implications for Development. Unpublished manuscript, 1985.

Curtis, James E. and John W. Petras, The Sociology of Knowledge: A Reader. New York: Prager University Press, 1972.

Davis, Harold Eugene. Latin American Thought: A Historical Introduction. New York: The Free Press, 1974.

"Trends in Social Thought," in Man, State and Society in Latin American History, edited by Sheldon and Peggy Liss. New York, Washington, London: Prager Publishers, 1972.

Delpar, Helen. Red Against Blue, The Liberal Party in Colombian Politics 1863-1899. Alabama: The University of Alabama Press, 1981.

Dix, Robert H., Colombia: The Political Dimenstions of Change. New Haven and London: Yale University Press, 1967.

The Politics of Colombia. New York, Wesport Conn., London: Praeger Publishers, 1987.

Dos Santos, Theotonio. "The Structure of Dependence," Readings on U.S. Imperialism. Boston: Sargent, 1971.

Dunkerley, James Power in the Isthmus: A Political History of Modern Central America. London, New York: Verso, 1988.

Edwards, Michael. "Cities of Tenants: Renting Among the Urban Poor in Latin America," in Urbanization in Contemporary Latin America: Critical Approaches to the Analysis of Urban Issues. Edited by Alan Gilbert. Chichester, New York, Toronto: John Wiley and Sons LTD., 1982.

Engels, Frederick. Socialism: Utopian and Scientific. Peking: Foreign Languages Press, (first published in French in 1880,) 1975.

Fals Borda, Orlando. Subversion and Social Change in Colombia. New York, London: Columbia University Press, 1969.

Fasel, George. Modern Europe in the Making: From the French Revolution to the Common Market. New York: Dodd, Mead \& Company, 1974. 
Fernandez, Raul A. and Jose F. Ocampo. "Recent Studies of Colombia," Latin American Perspectives. Vol. 2, No. 3 (Fall 1975).

Feuer, Lewis S. Marx and Engels: Basic Writings on Politics and Philosophy. Garden City, New York: Anchor Books, Doubleday and Company, Inc., 1959.

Fluharty, Vernon Lee. Dance of the Millions, Militry Rule and the Social Revolution in Colombia 1930-1956. Pittsburg: University of Pittsburg Press, 1966.

Frank, Andre Gunder. "Sociology of Development and Underdevelopment of Sociology," Dependence and Underdevelpment. New York: Monthly Review Press. 1971.

Funk-Harries, Richard, "Camilo Torres Restrepo and the Christian Left in the Tradition of Colombian Church-State Relations." Ph.D dissertation, Ann Arbor MI and London: University Microfilms International, 1980.

Gaitán, Gloria. La Lucha Por la Tierra en la Década del 30: Génesis de la Organización Sindical Campesina. Bogotá: El Ancora Editores, 1984.

Gaitán, Jorge Eliecer Las Ideas Socialistas en Colombia. Tesis de Grado, 1924, Bogotá: Librería Publicitaria, 1976.

García, Antonio. "Apuntes sobre el movimiento sindical colombiano," Revista Universidad de Antioquia. (October, 1935).

Gilhodès, Pierre "Agrarian Struggles in Colombia," in Agrarian Problems and Peasant Movements in Latin America edited by Rodolfo Stavenhagen. Garden City, New York: Anchor Books, Doubleday and Company, Inc., 1970.

Girvan, Norman. "The Development of Dependency Economics in the Caribbean and Latin America: Review and Comparison," Social and Economic Studies., Vol. 22, No. 1, March, 1973.

Gómez Támara, Adolfo. "La intervención de los sindicatos en la política," Revista Universidad de Antioquia. (December, 1945).

González, Fernán. Partidos Politicos y Poder Eclesiastico: Reseña Histórica 1810-1930. Bogotá: Editorial CINEP, 1977.

Greenfield, G. Michael and Sheldon L. Maram. Latin American Labor Organizations. New York, Wesport Conn., London: Praeger Publishers, 1987.

Hanagan, Michael and Charles Stephenson. Proletarians and Protest: The Roots of Class Formation in an Industrializing World. New York, Westport, Connecticut, London: Greenwood Press, 1986.

Hanke, Lewis. The Spanish Struggle for Justice in the Conquest of America. Boston: Little, Brown and Company, 1949.

Hanson, Roger The Politics of Mexican Development. Baltimore: Johns Hopkins University Press, 1982. 
Haring, C.H. The Spanish Empire in America. New York: Harcourt, Brace \& World, Inc., 1947.

Hart, John M. "The Urban Working Class and the Mexican Revolution: The Case of the Casa del Obrero Mundial," Hispanic American Historical Review. Vol. 58, No. 1, 1978.

Henao, Jesús María and Gerardo Arrubla. History of Colombia. Translated by Fred J. Rippy. New York: Greenwood Press Publications, 1969.

Hobsbawm, E.J. "Labor History and Ideology," Journal of Social History, 7 Summer 1974.

"Ideology and Social Change in Colombia," in Ideology and Social Change in Latin America, edited by June Nash, Juan Corradi and Hobart Spalding Jr. New York, London, Paris: Gordon and Breach Science Publishers Inc., 1977.

Hook, Sidney. Marx and the Marxists: the Ambiguous Legacy. Princeton, New Jersey: Van Nostrand, 1955.

Israel, Joachim. Alienation: From Marx to Modern Sociology. Boston: Allyn and Bacon Inc., 1971.

Jaguaribe, Helio. "Marxism and Latin American Development," in Marx and the Western World, New York: Praeger Publishers, Inc., 1966.

Johnson, Carlos. "Dependency Theory and the Processes of Capitalism and Socialism," Latin American Perspectives, Vols. 30 \& 31, No. 384, 1981.

Kalmanovitz, Salomón. Economía y Nación: Una Breve Historia de Colombia. Bogotá: Siglo Veintiuno Editores, 1985.

Kepner, David Charles and Jay Henry Soothill. The Banana Empire: A Case of Economic Imperialism. New York. The Vanguard Press, Inc., 1967.

Lansberger, Henry A. "The Labor Elite: Is it Revolutionary?," in Elites in Latin America, edited by Seymour M. Lipset and Aldo Solari. New York: Oxford University Press, 1967.

Law, John Power Action and Belief: A New Sociology of Knowledge? London, Boston and Henley: Routledge \& Kegan Paul, 1986.

LeGrand, Catherine. "Labor Acquisition and Social Conflict on the Colombian Frontier, 1850-1936." Latin American Studies. Vol. 16, 1985.

Levine, Daniel H., The Catholic Church in Venezuela and Colombia. Princeton, New Jersey: Princeton University Press, 1981.

Levine, Daniel H. and A. Wilde, "The Catholic Church, Politics, and Violence: The Colombian Case," The Review of Politics. Vol. 39, No. 2, April 1977). 
Lichtheim, George. Marxism: An Historical and Cultural Study. New York: Praeger Publishers, Inc., 1961.

Lipset, Martin Seymour and Aldo Solari. Elites in Latin America. New York: Oxford University Press, 1967.

Liss, Sheldon B. Marxist Thought in Latin America. Berkeley, Los Angeles, London: University of California Press, 1984.

Londoño, Jorge Ospina. Historia, Ideología y Politica. Medellín: Editorial Bedout, S. A., 1978.

Lukács, Georg. History and Class Consciousness: Studies in Marxist Dialectics. (Translated by Rodney Livingstone). Cambridge, Massachusetts: The MIT Press, 1968 .

Mannheim, Karl. Essays on the Sociology of Knowledge. London: Routledge \& Kegan Paul LTD., 1972.

Martz, John D. Colombia: A Contermporary Political Survey. Durham, N.C.: The University of North Carolina Press, 1962.

Marx, Karl. Pre-Capitalist Economic Formations. New York: International Publishers, translated by Jack Cohen, Introduction by E.J. Hobsbawm, 1977.

The Eighteenth Brumaire of Louis Bonaparte. Moscow: Progress Publishers, (First Published 1934,) 1977.

Wage Labour and Capital. Moscow: Progress Publishers, (Translated from the German edition of 1891 as edited by Frederick Engels) 1976.

Maullín, Richard. Soldiers, Guerrillas, and Politics in Colombia. Lexington, Massachusetts, London: D.C. Heath and Company, 1973.

McLellan, David. Marxism After Marx. Boston: Houghton Mifflin Co., 1979.

McGreevey, William Paul. An Economic History of Colombia. Cambridge, England: 1971.

"Reinterpreting Colombian Economic History," Journal of Interamerican Studies and World Affairs. Vol 23 No. 3 (August 1981).

"Urban Growth in Colombia," Journal of InterAmerican Studies and World Affairs. Vol. 16 No. 4 (November 1974).

Mecham, J. Lloyd. Church and State in Latin America. Chapel Hill, N.C.: University of North Carolina Press, 1934.

Medina, Medofilo. La Protesta Urbana en Colombia en el Siglo Veinte. Bogotá: Ediciones Aurora, 1984. 
Mejía, Alvaro Tirado. "Algunos Aspectos del Pensamiento de Lopez Pumarejo," Revista Universidad de Medellín. Medellín: Editorial Lealon, Vol. 49, May, 1986.

Molina, Gerardo. Las Ideas Socialistas en Colombia. Bogotá, Colombia: Ediciones Tercer Mundo, 1987.

Las Ideas Liberales en Colombia, 1915-1934. Bogotá, Colombia: Ediciones Tercer Mundo, 1982.

Molina, Gerardo. Las Ideas Liberales en Colombia, de 1934 a la Iniciación del Frente Nacional. Bogotá, Colombia: Ediciones Tercer Mundo, 1986.

Moncayo, Victor Manuel and Fernando Rojas. Luchas Obreras y Politica Laboral en Colombia. Bogotá: La Carreta, 1978.

Mutchler, David E., The Church as a Political Factor in Latin America. New York, Washington, London: Praeger Publishers, 1971.

Newton, June. "The Labor Movement of Colombia," University of Chicago, Master's dissertation, 1945.

Nyden, Philip W. "Democratizing Organizations: A Case Study of a Union Reform Movement," American Journal of Sociology. (90) Number 6, May 1985. pp. 1179-1203.

Oquist, Paul. Violence, Conflict and Politics in Colombia. New York, Toronto, San Francisco: Academic Press, 1980.

Palacios, Marco. Coffee in Colombia, 1850-1970: An Economic, Social and Political History. London, New York, New Rochelle: Cambreidge University Press, 1980.

Park, James William. Rafael Núñez and the Politics of Colombian Regionalism 18631886. Baton Rouge and London: Louisiana State University Press, 1985.

Parry, J.H. The Age of Reconnaissance: Discovery, Exploration, and Settlement 1450 to 1650. London: Weidenfeld and Nicolson, 1973

Patel, Surendra J. "The Technological Dependence of Developing Countries," The Journal of Modern African Studies. Vol. 12 No. 1, 1974.

Pecaut, Daniel. Politica y Sindicalismo en Colombia. Bogotá: Ediciones Culturales, 1982.

Pike, Frederick B. The Conflict Between Church and State in Latin America. New York: Alfred A. Knapt, Inc., 1964.

Ramos, Cesar Mendoza. Surgimiento y Desarrollo de la Clase Obrera en Barranquilla. Paper presented at the Third Congress of Colombian History, Universidad de Antioquia, Medellín, Colombia, November, 1981.

Randall, Stephen J. The Diplomacy of Modernization: Colombian-American Relations, 1920-1940. Toronto \& Buffalo: University of Toronto Press, 1977. 
Rattansi, Ali. "End of an Orhodoxy? The Critique of Sociology's View of Marx on Class," The Sociological Review. Volume 33, No. 4, November 1985.

Ray, David. "The Dependency Model of Latin American Development: Three Basic Fallacies," Journal of Inter-American Studies and World Affairs. Vol. 15, no. 1, 1973.

Restrepo, Camilo Torres, "La violencia y los cambios socioculturales en las areas rurales colombianas," Paper presented at the First National Sociology Conference, Bogotá, March 8-10, 1963. (Mimeo).

Rippy, J. Fred. The Capitalists and Colombia. Durham, NC: 1931

Rude, George. The Crowd in the French Revolution. London, Oxford, New York: Oxford University Press, 1977.

Sanchez, Gonzalo. Ensayos de Historia Social y Politica del Siglo XX: Los Bolcheviques del Líbano, Las Ligas Campesinas en Colombia, Las Raíces Históricas de la Amnistía. Bogotá: El Ancora Editores, 1985.

Sanchez, Ricardo. Historia Política de la Clase Obrera en Colombia. Bogotá: Editorial la Rosa Roja, 1982.

Safford, Frank. The Ideal of the Practical: Colombia's Struggle to Form a Technical Elite. Austin and London: University of Texas Press, 1976.

Schwann, Hubert and A.L Ugalde, "Orientations of the Bishops of Colombia Toward Social Development, 1930-1970.' Journal of Church and State. Vol. 16, No. 3 Autumn 1974).

Shapiro, Samuel, Cultural Factors in Inter-American Relations. Notre Dame: University of Notre Dame Press, 1968.

Skidmore, Thomas E. "Workers and Soldiers: Urban Labor Movements and Elite Responses in 20th Century Latin America," in Elites, Masses and Modernization in Latin America, 1850-1930, edited by Bradford Burns and Thomas E. Skidmore. London, Austin: University of Texas Press, 1978.

Sloan, John W. "Regionalism, Political Parties, and Public Policy in Colombia," InterAmerican Economic Affairs, 33 (3), 1979, 25-46.

Sowell, David Lee. "The Early Latin American Labor Movement: Artisans and Politics in Bogotá, Colombia, 1832-1919. PhD. Dissertation University of Florida, 1986.

Spalding, Hobart. Organized Labor in Latin America: Historical Case Studies of Urban Workers in Dependent Societies. New York: 1977.

Stavenhagen, Rodolfo. Agrarian Problems and Peasant Movements in Latin America. Garden City, New York: Anchor Books, Doubleday and Company, Inc., 1970.

Stearns, Peter N. "Measuring the Evolution of Strike Movements," International Review of Social History. 19, 1974:1-27. 
Szuchman, Mark D. " The Faces of Labor in Latin America: Migration, Tradition and Organization," Journal of Urban History. Vol. 11 no. 4, (August, 1985).

Targ, Harry. "Global Dominance and Dependence, Post-Industrialism, and International Relations Theory," International Studies Quarterly, Vol. 20, no. 3, Sept. 1976.

Therborn, Göran. The Ideology of Power and the Power of Ideology. London: verso Editions and NLB, Redwood Burn Lmtd., 1980.

Thompson, E.P. The Making of the English Working Class. New York: Vintage Books, 1966.

Tirado, Thomas C. Alfonso Lopez Pumarejo: El Conciliador. Bogotá: Planeta Editorial S.A., 1986.

Tomasek, Robert D., Types of Catholic Elites in Latin America:, Latin American Politics. Garden City, New York: Anchor Books, Doubleday and Company, Inc., 1970.

Toro, Alvaro Lopez. Migración y cambio social en Antioquia durante el siglo XIX. Medellín: Ediciones Hombre Nuevo, 1979.

Torres Giraldo, Ignacio. Los inconformes. Bogotá: Editorial Margen Izquierdo, 1974.

Troncoso, Moises and Ben Burnett. The Rise of the Latin American Labor Movement. New York: Bookman Associates United Printing Services, 1960.

Tucker, Robert C. The Marx-Engels Reader. New York, London: W.W. Norton and Company, 1978.

Urrutia, Miguel. The Development of the Colombian Labor Movement. New Haven, London: Yale University Press, 1969.

Valencia, Enrique. "El Movimiento Obrero Colombiano" in Historia del Movimiento Obrero en América Latina, Volume 3. Edited by Pablo González Casanova. Mexico: Siglo Veintiuno Editores, 1984.

Vallier, Ivan. Catholicism Social Control and Modernization in Latin America. New Jersey: Prenice-Hall, Inc., 1970.

Wallerstein, Immanuel. The Modern World System I. New York: Academic Press, 1974.

Wallerstein, Immanuel. "The World Capitalist System," Comparitive Studies in Society and History. Vol. 16., Sept. 1974.

Whipp, Richard. "Labour Markets and Communities: An Historical View," The Sociological Review. Volume 33, No. 4, November 1985.

Whiteford, Andrew H. Two Cities of Latin America: A Comparative Description of Social Classes. New York: Doubleday and Company, 1964.

Whiteford, Michael B. The Forgotten Ones: Colombian Countrymen in an Urban Setting. Gainesville, Florida: The University Presses of Florida, 1976. 
Wolff, Kurt H. Beyond the Sociology of Knowledge: An Introduction and a Development. Lanham, New York, London: John Wiley and Sons, Inc., 1983.

Woodward, Ralph L. Central America: A Nation Divided. New York: Oxford University Press, 1976.

Worsley, Peter. "One World or Three? A Critique of the World System Theory of Immanuel Wallerstein" in David Held ed. States and Societies. New York \& London: New York University Press, 1983.

Zea, Leopoldo. "The Struggle for Intellectual Emancipation," in Man, State and Society in Latin American History. Edited by Sheldon B. Liss and Peggy Liss. New York, Washington, London: Praeger Publishers, 1972.

Zeitlin, Irving M. Ideology and the Development of Sociological Theory. Englewood Cliffs, New Jersey: Prentice-Hall, Inc., 1968.

Zambrano, Bernardo Tovar. La Intervención Económica del Estado en Colombia 19141936. Bogotá: Biblioteca Banco Popular, 1984. 